\title{
A PRESERVAÇÃO DO PATRIMÔNIO CULTURAL URBANO: FUNDAMENTOS, AGENTES E PRÁTICAS URBANÍSTICAS
}

Tese apresentada à Faculdade de Direito da Universidade de São Paulo como requisito parcial para a obtenção do título de Doutora em Direito do Estado, sob orientação do Professor Doutor Fernando Dias Menezes de Almeida.

São Paulo 
Banca Examinadora

Prof.

Prof.

Prof.

Prof.

Prof. 


\section{AGRADECIMENTOS}

Minha imensa gratidão ao Professor Fernando Dias Menezes de Almeida, por ter me apoiado e me motivado, continuada e irrestritamente, neste programa de doutorado e em muitos outros trabalhos, ao longo dos últimos 8 anos.

Meu reconhecimento também ao Professor Nestor Goulart Reis Filho, que em mais de uma oportunidade me recebeu pronta e solicitamente na Faculdade de Arquitetura e Urbanismo da USP, dedicando horas do seu tempo para me ofertar suas preciosas lições, assim como para sugerir textos engrandecedores, norteando-me com maestria neste multifacetado tema.

Agradeço a este Professor, assim como ao Professor Luis Virgílio Afonso da Silva pelas recomendações feitas por ocasião do meu exame de qualificação, as quais foram decisivas para uma melhor delimitação e um direcionamento adequado deste trabalho. Desde já assumo toda e qualquer responsabilidade pelo não aproveitamento a contento dessas recomendações recebidas.

Ao Ricardo, pela sua afetuosa presença e pelo apoio incondicional durante esse período de reflexão e escrita. Aos meus pais, Nemias e Blandina, pela prazerosa acolhida e por todo o incentivo recebido, desde pequena, para continuar sempre seguindo.

Por fim, pelo carinho e pelo auxílio que todos eles me dedicaram enquanto eu elaborava este trabalho, agradeço às minhas irmãs Paula Regina da Cruz Noia e Luciana da Cruz Noia, ao meu cunhado Jaime Meira do Nascimento Jr. e aos amigos Ana Sylvia de Faria Almeida Prado, Matthieu Iochum, Natasha Schmidt Caccia Salinas, Carolina Theodoro da Silva Mota, Maria Paula Bertran e Ana Carolina Modinger. 
Para Ricardo 


\section{SUMÁRIO}

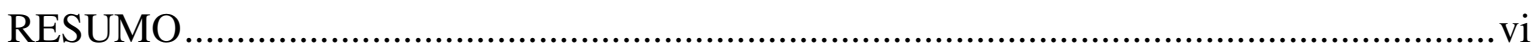

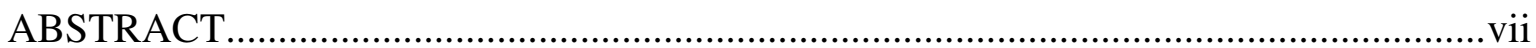

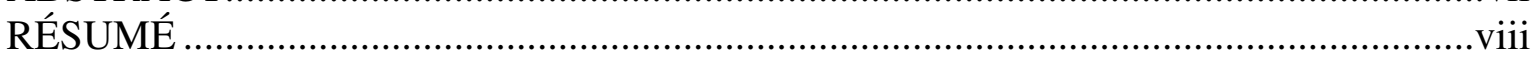

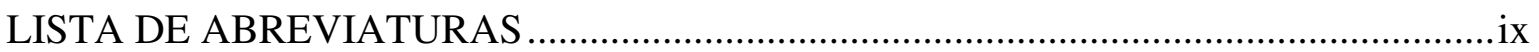

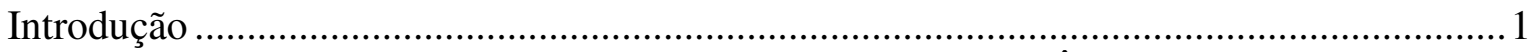

Capítulo 1 OS FINS: POR QUE PRESERVAR O PATRIMÔNIO CULTURAL? .........6

1.1. Antecedentes normativos da preservação no mundo ocidental .................................7

1.2. Fundamentos da preservação em documentos internacionais ................................. 12

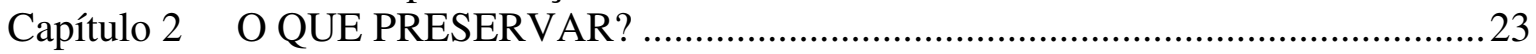

2.1. A noção de patrimônio cultural nos documentos internacionais ..............................23

2.2. A concepção jurídica de patrimônio cultural segundo a Constituição Federal de

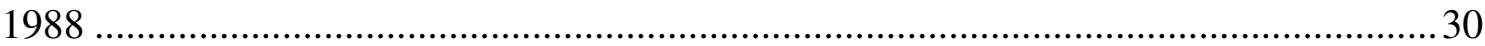

Capítulo 3 OS MEIOS: QUEM PRESERVA O PATRIMÔNIO CULTURAL

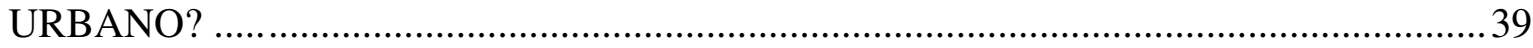

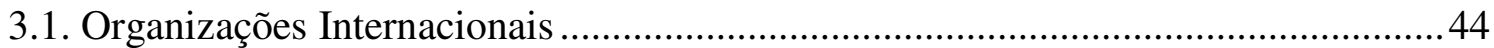

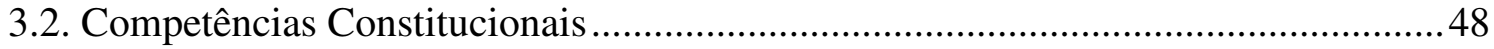

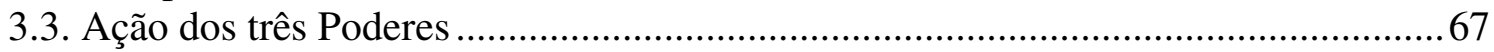

3.3.1. O Decreto-lei n $25 / 37$ enquanto lei geral de preservação do patrimônio cultural

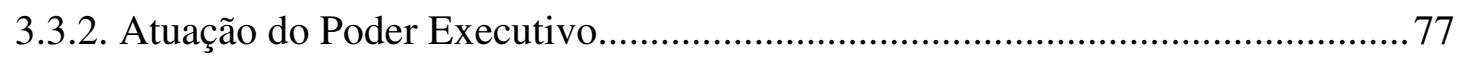

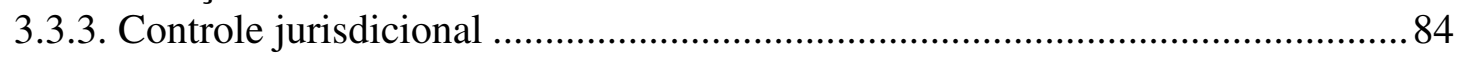

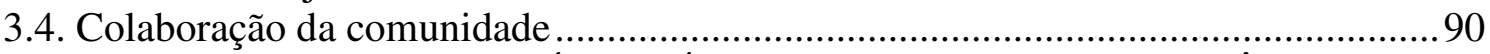

Capítulo 4 OS MEIOS: COMO É POSSÍVEL PRESERVAR O PATRIMÔNIO

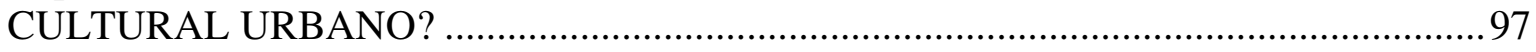

4.1. A Proteção Internacional do Patrimônio Cultural da Humanidade ......................... 101

4.2. Mecanismos tradicionais: o tombamento e a desapropriação ..............................110

4.3. O Estudo Prévio de Impacto de Vizinhança e a tutela da paisagem cultural ...... 127

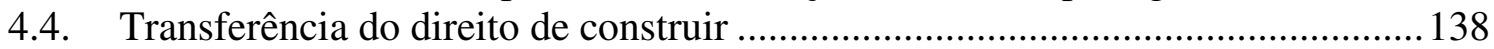

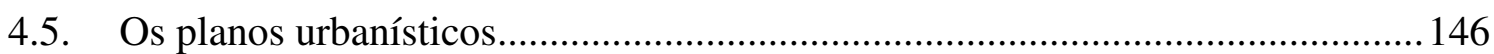

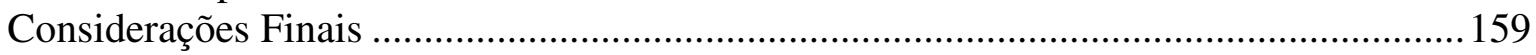

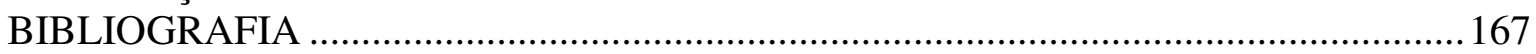

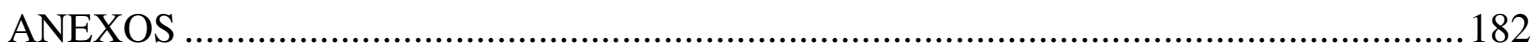




\section{RESUMO}

O presente trabalho trata da preservação do patrimônio cultural urbano desempenhada pelo Estado mediante o exercício da atividade urbanística. Mais especificamente, analisa os fundamentos, assim como os agentes e as práticas admitidos no ordenamento jurídico brasileiro para que se alcance esta finalidade última de conservar, às presentes e futuras gerações, determinados valores culturais contidos nas cidades.

A expressão patrimônio cultural urbano foi adotada neste trabalho como abrangente tanto dos monumentos e conjuntos históricos e arquitetônicos isoladamente considerados - cujos valores culturais são mais facilmente identificados nas suas estruturas físicas, materiais -, quanto do próprio ambiente construído e humanizado das cidades (composto por parques, praças e outros espaços, sempre quando utilizados em práticas culturais e manifestações sociais), o qual carrega em si valores de natureza marcadamente imaterial, relevantes pela capacidade de proporcionarem bem-estar e qualidade de vida aos habitantes da cidade.

Como ponto de partida dessa abordagem, são mencionados sumariamente alguns antecedentes normativos reveladores de que preocupações oficiais com a tutela de bens culturais existiam desde a Antiguidade. Em seguida, é feita uma análise evolutiva dos fundamentos dessa preservação, assim como das noções de patrimônio cultural adotados em alguns dos principais documentos internacionais que tratam sobre o tema. Também são analisadas as inovações trazidas pela Constituição Federal de 1988 tanto para a concepção jurídica de patrimônio cultural, quanto para a disciplina urbanística.

Também é dedicada atenção aprofundada aos sujeitos que, de acordo com o ordenamento jurídico pátrio, estão incumbidos de - ou legitimados a - atuar na preservação do patrimônio cultural urbano. Por fim, são especialmente investigados os principais instrumentos urbanísticos disponíveis à consecução dessa tarefa, sugerindo, com o devido embasamento, que a preservação do patrimônio cultural urbano deve ser conduzida de maneira planejada, dispensando-se uma visão urbanística às questões relacionadas àquela. 


\begin{abstract}
The present study deals with the preservation of cultural heritage provided by the State through the exercise of urbanistic activity. More specifically, it analyzes the foundation, agents and practices admitted by Brazilian legal system to reach the goal of preserving, to present and future generations, certain cultural values existing in the cities.
\end{abstract}

The expression urban cultural heritage was adopted in this study as comprehensive of historical and architectural monuments and aggregations taken in an isolated manner - whose cultural values are most easily identified in their physical and material structures - as well as of the built and humanized environment of cities (made up of parks, squares and other spaces used in practices and social events), which carries cultural values of immaterial nature, relevant for the ability to provide welfare and quality of life for city residents.

As a starting point of this approach, it is briefly mentioned some legislative history pointing out that official concerns with the protection of cultural heritage existed since Antiquity. Next, this work examines the evolutionary reasons given for conservation, as well as the notions of cultural heritage adopted by the main international documents that deal with the issue. It also analyzes the innovations made by the Brazilian Federal Constitution for both the legal concept of cultural heritage and for urban discipline.

Deep attention is also devoted to the agents that, according to the Brazilian legal system, are in charge of acting on the preservation of urban cultural heritage or even legitimated to do so. Finally, it also investigates the main urbanistic instruments available to achieve this task, suggesting with proper foundation, that the preservation of urban cultural heritage should be conducted in a planned manner, dispensing an urbanistic view to related issues. 


\section{RÉSUMÉ}

La présente thèse traite de la préservation du patrimoine culturel entrepris par l'Etat à travers l'exercice de l'activité urbanistique. Plus spécifiquement, examine les fondements, les agents et pratiques existant dans l'ordonnancement juridique brésilien qui permettent d'atteindre l'objectif de conserver, pour les générations présentes et futures, certains valeurs culturels contenues dans les villes.

L'expression patrimoine culturel urbain utilisée dans cette thèse englobe aussi bien les monuments et ensembles historiques et architecturaux envisagés séparément dont la valeur culturelle est plus facilement identifiée de par leur structure physique, matériel -, que l'environnement bâti et aménagés des villes (composés de parcs, places et autres espaces, quand ils sont utilisés lors de pratiques culturelles et manifestations sociales), qui contiennent intrinsèquement des valeurs culturelles de nature fondamentalement immatérielle, aptes à procurer une certaine qualité de vie aux habitants de la ville.

Comme point de départ de cette approche certaines normes anciennes sont sommairement mentionné, révélant qu'il existait depuis l'Antiquité des préoccupations officielles concernant la tutelle des biens culturels. Ensuite, il est procédé à une analyse évolutive des raisons de cette conservation, ainsi que des notions de patrimoine culturel utilisées dans les principaux documents internationaux relatifs à ce thème. Sont aussi analysées les innovations apportées par la Constitution Fédérale de 1988 tant sur la concepción juridique de patrimoine culturel que sur la discipline urbanistique.

Il est aussi question des sujets à qui, conformément à l'ordonnancement juridique national, il incombe de - ou qui sont appelés à - agir pour la conservation du patrimoine culturel urbain brésilien. Enfin, ont aussi examinés particulièrement les principaux instruments urbanistiques disponibles pour accomplir cette tâche, ce qui suggère, avec fondement, que la préservation du patrimoine culturel urbain soit conduite d'une manière planifiée, dispensant une vison urbanistique aux questions concernées à ce sujet. 


\section{LISTA DE ABREVIATURAS}

\begin{tabular}{|c|c|}
\hline AIA & Avaliação de Impacte Ambiental \\
\hline CONDEPACC & Conselho de Defesa do Patrimônio Cultural de Campinas \\
\hline CONDEPHAAT & $\begin{array}{l}\text { Conselho de Defesa do Patrimônio Histórico, Arqueológico, } \\
\text { Artístico e Turístico do Estado de São Paulo }\end{array}$ \\
\hline CONPRESP & $\begin{array}{l}\text { Conselho Municipal de Preservação do Patrimônio Histórico, } \\
\text { Cultural e Ambiental da Cidade de São Paulo }\end{array}$ \\
\hline DIA & Declaração de Impacte Ambiental \\
\hline DPHA & Divisão de Patrimônio Histórico e Artístico do Estado da Guanabara \\
\hline Dphan & Departamento do Patrimônio Histórico e Artístico Nacional \\
\hline EIA & Estudo Prévio de Impacto Ambiental \\
\hline EIV & Estudo Prévio de Impacto de Vizinhança \\
\hline FCC & Fundação Catarinense de Cultura \\
\hline FPACBA & Fundação do Patrimônio Artístico e Cultural da Bahia \\
\hline FUNDARPE & Fundação do Patrimônio Histórico e Artístico de Pernambuco \\
\hline ICCROM & $\begin{array}{l}\text { Centro Internacional de Estudos para a Conservação e o Restauro de } \\
\text { Bens Culturais }\end{array}$ \\
\hline ICOMOS & $\begin{array}{l}\text { International Council on Monuments and Sites (Conselho } \\
\text { Internacional dos Monumentos e dos Sítios) }\end{array}$ \\
\hline IEPHA & $\begin{array}{l}\text { Instituto Estadual do Patrimônio Histórico e Artístico do Estado de } \\
\text { Minas Gerais }\end{array}$ \\
\hline IPHAE & $\begin{array}{l}\text { Instituto do Patrimônio Histórico e Artístico do Estado do Rio } \\
\text { Grande do Sul }\end{array}$ \\
\hline IPHAN & Instituto de Patrimônio Histórico e Artístico Nacional \\
\hline IPTU & Imposto Predial de Propriedade Territorial Urbana \\
\hline MES & Ministério da Educação e Saúde \\
\hline OEA & Organização dos Estados Americanos \\
\hline ONU & Organização das Nações Unidas \\
\hline RIVI & Relatório de Impacto de Vizinhança \\
\hline SPHAN & Serviço de Patrimônio Histórico e Artístico Nacional \\
\hline Sudene & Superintendência de Desenvolvimento do Nordeste \\
\hline TDR & Transfer of Development Rights \\
\hline UIP & Unidades de Interesse de Preservação \\
\hline UNESCO & Organização das Nações Unidas para a Educação, Ciência e Cultura \\
\hline
\end{tabular}




\section{Introdução}

O surgimento das cidades, na Antiguidade, oferece a percepção de que determinadas necessidades dos indivíduos (tais como a segurança e o desenvolvimento de atividades comerciais) somente - ou muito mais facilmente - se satisfazem quando estes se dispõem a viver em coletividade. Declinam, assim, cada um desses indivíduos, de parte dos seus interesses pessoais e reúnem-se em prol da satisfação de outra parcela de interesses, comuns a toda a coletividade.

Por outro lado, o ambiente urbano acaba exercendo influência fundamental sobre o modo de vida dos seus habitantes. Por exemplo, as densidades demográficas, as formas de organização sócio-espaciais, a quantidade de equipamentos disponíveis à garantia do exercício dos mais diversos direitos difusos, tais como saúde, habitação, transporte e lazer, são todos fatores que, de algum modo e em algum grau, influenciam o bem-estar e a qualidade de vida dos habitantes.

Em termos urbanísticos, para que uma cidade $^{1}$ proporcione satisfatoriamente estas duas últimas situações, é importante que ela seja planejada de tal forma que ofereça espaços e equipamentos adequados à habitação, ao trabalho, à circulação e ao lazer, assim como meios propícios ao exercício pleno da cidadania, esta somente alcançada mediante a garantia aos indivíduos de perfeita percepção de si próprios como partes essenciais e fazedoras do meio em que vivem.

Assim, é importante que o ambiente urbano proporcione a integração entre os habitantes, estimule as relações sociais, promova o crescimento e o desenvolvimento

\footnotetext{
${ }^{1}$ José Afonso da Silva ressalta a dificuldade de fixação do conceito de cidade e destaca inúmeras concepções possíveis desta. Neste parágrafo da Introdução, a expressão cidade é tomada não exatamente na sua concepção jurídico-política brasileira (como sendo restritamente o núcleo urbano, sede do governo municipal), mas numa noção mais ampliada, demográfica e quantitativa, correspondente a um aglomerado urbano com dimensões e densidade populacional considerável e determinado de habitantes.
} 
da educação e da cultura. Satisfeitas essas condições, entende-se que a cidade terá cumprido ao menos parte de sua função social ${ }^{2}$.

Nesse contexto é que se revela a importância da preservação do patrimônio cultural no ambiente urbano, tanto para garantia de bem-estar e qualidade de vida aos seus habitantes, como para o próprio desenvolvimento das cidades, pois permite o resguardo de uma memória às comunidades formadoras da sociedade e, com isso, a percepção, por parte desses indivíduos, tanto de suas próprias identidades, quanto de sua importância para o meio em que vivem e vice-versa.

No presente trabalho, a expressão patrimônio cultural urbano é tomada no sentido de compreender a globalidade dos bens culturais edificados presentes no ambiente urbano. Abriga não somente os monumentos e conjuntos históricos e arquitetônicos tomados isoladamente - cujos valores culturais revelam-se mais evidentemente nas suas próprias estruturas físicas, materiais -, quanto o próprio ambiente construído e humanizado das cidades (composto por parques, praças, e outros espaços), o qual, na medida em que utilizado por seus habitantes para realização de práticas culturais e manifestações sociais, adquire relevância simbólica para estes.

Este patrimônio cultural, tão importante à vida nas cidades, não deve prescindir de reflexões por parte do Poder Público quando da elaboração de políticas públicas, tampouco ser relegado quando do planejamento urbano, sob o risco de não se exercer adequadamente a função social da cidade. Nesse contexto, a chamada gestão democrática da cidade, consagrada pela Lei n. 10.257/01, revela-se fundamental para o conhecimento e a satisfação dos reais interesses culturais da sociedade.

Em matéria de patrimônio cultural, o Município - enquanto ente da Federação que mais próximo está dos anseios e das manifestações dos seus indivíduos - pode contribuir sobremaneira para o sucesso e a legitimidade da preservação de valores culturais contidos no ambiente urbano, estando apto a perceber, inclusive com a

\footnotetext{
${ }^{2}$ A Lei 10.257/01 (Estatuto da Cidade) refere-se às funções sociais da cidade como um dos objetivos a serem alcançados pela política urbana (art. $2^{\circ}$ ).
} 
participação de suas comunidades, os valores referenciais a estas, ou seja, aqueles valores que mereçam ser mantidos na memória urbana. São diversos os instrumentos jurídicos urbanísticos disponíveis ao Município para alcançar esse fim, devendo empregá-los de maneira razoável e proporcional, conforme o tipo de bem e o modo de tutela que se almeja dispensar.

Mas como condição para que sejam eficazes e tenham satisfatória duração no tempo, é indispensável também que as ações municipais de conservação e promoção do patrimônio cultural urbano não sejam pensadas de maneira isolada, mas sim no contexto espacial da cidade, a demandar uma gestão ordenada das várias funções sociais desta. Portanto, devem guardar estrita consonância com a política maior de desenvolvimento desenhada para a cidade. Por exemplo, definindo-se o aproveitamento de edificações já existentes na cidade e dotadas de alguma significação cultural para novos usos ${ }^{3}$.

Por outro lado, qualquer programa municipal de preservação do patrimônio cultural local deve estar igualmente em perfeita sintonia com as diretrizes nacionais e regionais que se estabelecerem no plano da preservação do patrimônio cultural brasileiro, assim como com as diretrizes gerais traçadas pela União para o desenvolvimento urbano das cidades ${ }^{4}$. Com efeito, a cooperação entre Municípios, Estados federados respectivos e União é diretriz constitucional em matéria de preservação do patrimônio cultural urbano.

É o que se depreende da leitura sistematizada dos dispositivos constitucionais aplicáveis à matéria, a indicar, nesse tema, a adoção pela Constituição de 1988 de "um sistema de racionalidade decisória em que as normas e decisões em matéria urbanística [...] têm sua validade condicionada ao respeito de normas e decisões de maior abrangência",5.

\footnotetext{
${ }^{3}$ É o que defende Nestor Goulart Reis Filho, entendendo ser preferível econômica e culturalmente o ajuste dessas edificações a novos usos na cidade. "Desenvolvimento urbano e uma nova política de conservação", p. 38.

${ }^{4}$ Hoje expressas na Lei n. 10.257/01.

${ }^{5}$ Cf. Carlos Ari Sundfeld. "O Estatuto da Cidade e suas diretrizes gerais". In Estatuto da Cidade: Comentários à Lei Federal 10.257/2001, p. 50. Grifos do autor.
} 
Em 1988, foi dedicado pela primeira vez tratamento constitucional sistematizado à questão urbana. Não se limitou a Constituição Federal a atribuir competência legislativa explícita à União para editar normas gerais de direito urbanístico e competência suplementar aos estados e municípios, o que por si só já seria algo inovador, posto que expressivo de uma compreensão do direito urbanístico transcendente dos limites e interesses estritamente locais.

Mais que isso, a Constituição trouxe finalmente para o plano constitucional a questão da política espacial da cidade ${ }^{6}$, a ensejar, nos três âmbitos federativos, ações estatais coordenadas de ordenação e planejamento do desenvolvimento urbano nacional, com vistas a garantir às cidades brasileiras o exercício pleno de suas funções sociais e o bem-estar dos seus habitantes (art. 182, caput e parágrafos). Ao mesmo tempo, a Constituição de 1988 também dispensou tratamento inovador ao tema da preservação do patrimônio cultural.

É notável o entrelaçamento entre esses dois temas no plano constitucional, à medida que ambos se projetam para o alcance de um bem-estar social e do desenvolvimento nacional equilibrado e, para tanto, servem-se de competências materiais e legislativas concorrentes que sinalizam a importância do planejamento e da coordenação nacional.

A presente tese parte de uma constatação fundamental de que, do ponto de vista jurídico, a preservação do patrimônio cultural urbano somente faz sentido se este for tomado numa visão de conjunto, ou seja, numa visão ambiental do universo patrimonial. De efeito, de acordo com as orientações jurídicas contemporâneas atinentes à matéria, o tratamento pontual e isolado de bens culturais, não se faz mais adequado para garantia da projeção do patrimônio cultural urbano às gerações presentes e futuras.

Feita essa constatação inicial, sustenta-se, no presente trabalho, que, para a preservação ambiental do patrimônio cultural urbano, faz-se necessária a adequada

\footnotetext{
${ }^{6}$ Uma proposta de Lei Nacional de Reforma Urbana vinha sendo pensada no Governo desde 1977. O tema chegou ao Congresso Nacional para discussão somente em 1983, sob a forma do Projeto de Lei $\mathrm{n}^{\circ}$ 775/1983. Após ter enfrentado sucessivas resistências à sua aprovação, por alegada presença de inconstitucionalidade no seu teor, o Projeto acabou tendo sua essência reproduzida na Constituição de 1988.
} 
articulação das competências dos entes constitucionalmente incumbidos dessa tarefa, assim como a aplicação dos instrumentos urbanísticos mais apropriados para a tutela almejada, considerado cada caso.

Aquela constatação inicial encontra-se desenvolvida preliminarmente nos Capítulos 1 e 2. O Capítulo 1 dedica atenção especialmente aos fundamentos jurídicos da preservação que ao longo do tempo foram reproduzidos nas principais normas internacionais atinentes ao tema. Já o Capítulo 2 aborda a evolução da concepção jurídica de patrimônio cultural no plano normativo internacional, assim como analisa a concepção adotada pela Constituição de 1988. O Capítulo 3 propõe análise pormenorizada dos agentes incumbidos de agir com vistas à preservação do patrimônio cultural urbano no Brasil, mais especificamente verificando o modo como coordenadas as suas competências. Também se verificam os modos como assegurada juridicamente a participação social nos processos de formação e tutela desse patrimônio. Por fim, o Capítulo 4 traz uma exposição pormenorizada dos instrumentos urbanísticos hoje disponíveis no ordenamento jurídico pátrio para esses fins de preservação do patrimônio cultural urbano, propondo a gestão planejada do patrimônio cultural urbano, integrada com os demais planos de desenvolvimento e ordenação urbana. 


\section{Capítulo 1 OS FINS: POR QUE PRESERVAR O PATRIMÔNIO CULTURAL?}

Cada cidade tem a sua fisionomia, a sua feição, como as pessoas têm um conjunto de traços com os quais se constrói a sua identidade, o seu caráter. Mas a fisionomia se transforma com o tempo.

Nestor Goulart Reis Filho ${ }^{7}$

Neste primeiro Capítulo, proceder-se-á inicialmente a um breve relato histórico-evolutivo de normas de caráter notadamente protecionista editadas no mundo ocidental. O objetivo principal é demonstrar que, desde a civilização romana antiga, sempre existiram preocupações oficiais com a conservação de bens considerados culturalmente relevantes, presentes em núcleos urbanos. Isso, em que pese se reconheça não somente que o alcance dessas preocupações oficiais e a habitualidade com que elas se manifestaram variaram consideravelmente ao longo dos tempos, como também que as razões que as impulsionaram sofreram mudanças significativas até que se chegasse ao estágio atual de consagração do patrimônio cultural como um direito difuso garantido pela maioria das Constituições nacionais contemporâneas às presentes e futuras gerações.

Em seguida, ainda neste Capítulo, serão especialmente analisados os fundamentos expostos nas principais cartas e normas internacionais que tratam sobre o tema, justificadores das recomendações internacionais dirigidas aos Estados nacionais, no sentido de que estes protejam seus respectivos patrimônios culturais.

\footnotetext{
${ }^{7}$ São Paulo e outras cidades, p. 17.
} 
A opção de se utilizar as cartas e normas internacionais, neste e no próximo Capítulos, como materiais de análise dos fundamentos e do objeto da ação estatal preservacionista deve-se à necessidade de estabelecer-se um corte ao presente estudo, assim como ao fato daquelas refletirem as principais questões doutrinárias e conceituais debatidas por especialistas do mundo todo sobre o tema, enfatizando, nas últimas décadas, a importância de um olhar para o patrimônio cultural urbano em sua globalidade.

Ademais, é sabido que as atuações, no Brasil, dos órgãos responsáveis pelo tombamento, conservação e restauração de bens arquitetônicos foram e ainda hoje são norteadas, na prática, pelas determinações emanadas dessas cartas patrimoniais internacionais. ${ }^{8}$

\subsection{Antecedentes normativos da preservação no mundo ocidental}

Desde a Antiguidade, registra-se a existência de normas voltadas à preservação de patrimônios construídos. O alcance, os fundamentos e os parâmetros dessa proteção, no entanto, é que variaram conforme o tempo e o espaço considerados.

Assim, em aproximadamente 44 d. C., já vigorava na cidade de Herculano, na atual Itália, um Decreto que obrigava os indivíduos que demolissem uma edificação com fins especulativos a pagarem às autoridades valor equivalente ao dobro do preço de compra do imóvel. Também na época romana, no ano de 389, um Édito dos imperadores Valentiniano, Teodósio e Arcádio proibia acréscimos modernos que desfigurassem ornamentos exteriores de edificações privadas e vedava a danificação de construções históricas de cidades importantes por razões de cobiça ou ânsia de lucro 9 .

\footnotetext{
${ }^{8}$ Carlos Alberto Cerqueira Lemos, "Apresentação", In Patrimônio: Atualizando o debate, Victor Hugo Mori et alli, p. 13.

${ }^{9}$ Miguel Brito Correia, "Enquadramento Histórico das Normas Internacionais", In Flavio Lopes; Miguel Brito Correia (org.), Património Arquitectónico e Arqueológico: Cartas, Recomendações e Convenções, p. 13.
} 
Não obstante estes exemplos, é de se destacar que normas de feições marcadamente preservacionistas ainda eram raras e de alcance muito restrito nesse tempo, vislumbrando-se semelhante situação na Idade Média ${ }^{10}$.

A partir do Renascimento, assiste-se a um expressivo aumento no número de normas de proteção publicadas na Europa.

Somente na região da Itália, nos séculos XV e XVI, registra-se a produção de diversas bulas papais que tinham por objeto a restauração e a conservação de equipamentos urbanos e de monumentos ${ }^{11}$. Também foram publicados inúmeros outros atos, por diferentes Papas, cujas disposições proibiam a pilhagem de achados arqueológicos, a extração de partes de monumentos para emprego em construção nova, assim como a exportação de antiguidades ${ }^{12}$. Na região da Toscana, a Lei de 30 de maio de 1571 continha igualmente um viés claramente protecionista. ${ }^{13}$

Fora da península itálica - porém ainda no âmbito da Europa - são citadas como normas que trataram pioneiramente da tutela de bens culturais: a Proclamation agaynst breakynd or defacing of monuments, publicada em 19 de setembro de 1560 pela Rainha Isabel I da Inglaterra, em reação à forte onda de destruições de igrejas e outros ícones das ordens religiosas recém abolidas; e o Decreto sobre Monumentos Antigos, publicado em 28 de novembro de 1666 pelo Rei Carlos XI da Suécia, que

\footnotetext{
${ }^{10}$ Miguel Brito Correia, op. Cit., p. 13. Sobre normas de proteção do patrimônio construído na Idade Média, cf. Ferdinand Adolf Gregorovius, History of the City of Rome in the Middle Ages, 1967. Cf. também Cevat Erder, Our Cultural Heritage: From Consciousness to Conservation, Museums and Monuments Series XX, p. 103.

${ }^{11}$ Como exemplos, vale citar a Bula do Papa Martinho V Etsi in cunctarum orbis, de 30 de março de 1425, que restabeleceu a função de magistri viarum, responsável pela reparação de ruas, pontes, portas, muros, edifícios; a Bula do Papa Pio II Cum alman nostram urbem, de 28 de abril de 1462, contra a destruição de monumentos da Antiguidade; e a Bula do Papa Sisto IV Quum provvida, 25 de abril de 1574.

${ }^{12}$ A ved ação da exportação de antiguidades foi objeto específico do Decreto do Papa Urbano VIII, de 5 de outubro de 1624. Françoise Choay lembra caber aos Papas, nesse período, a tarefa de preservação e que a dilapidação de monumentos, assim como a apropriação privada de antiguidades clássicas eram muito comuns e haveriam de crescer com o florescimento do comércio de objetos artísticos. A alegoria do patrimônio, p. 53-59.

${ }^{13}$ Miguel Brito Correia também noticia uma sequência de atos normativos protecionistas publicados nessa mesma região em 1646, em 1717, em 1726, em 1733 e em 1750. Op. Cit, p. 13-14.
} 
diversamente da lei inglesa, refletia tão somente o empenho deste monarca de ver aprofundado o conhecimento da História deste país ${ }^{14}$.

Por ocasião da Revolução Francesa, uma série de princípios norteadores de políticas de salvaguarda ganhou forças com vistas a rechaçar as graves ameaças de destruição de monumentos da história, da arte e da ciência, os quais, então recém "reavidos" do clero ${ }^{15}$ e da Coroa pela Nação, passaram a ser vistos como integrantes do patrimônio nacional francês.

A este patrimônio fora reconhecido valor cultural e educativo, impondo-se a toda a Nação o dever de sua conservação integral ${ }^{16}$. As ameaças a este patrimônio derivavam especialmente da perda brutal das destinações originais dos bens que o integravam - em razão da transferência de titularidade destes ${ }^{17}$-, assim como da força da destruição ideológica de que parte deles tornara-se alvo a partir de $1792^{18}$.

${ }^{14}$ Miguel Brito Correia, Op. Cit., p. 14 .
${ }^{15}$ A colocação dos bens do clero à disposição da Nação foi um dos primeiros atos produzidos pela Constituinte, em 2 de outubro de 1789.

${ }^{16}$ Miguel Brito Correia, Op. Cit., p. 14.

17 “[...] antes de qualquer decisão sobre sua destinação futura, estes [bens que passam a compor o patrimônio da nação] são protegidos e postos 'fora de circulação' em caráter provisório, [...]. [...] Mas o problema fundamental é a necessidade de decidir, em regime de urgência e de forma que resguarde o interesse coletivo, sobre a destinação dos objetos heterogêneos que se tornaram patrimônios da nação". Françoise Choay, $A$ alegoria do patrimônio, p. 100. Esta mesma autora prossegue analisando, mais adiante, que: "Os bens imóveis, conventos, igrejas, castelos, residências particulares ensejavam outros problemas [diferentes dos verificados para os bens móveis], em outra escala, e as comissões revolucionárias encarregadas de sua conservação mostravam-se ainda mais despreparadas para isso do que no caso dos depósitos. Do estrito ponto de vista da manutenção, elas não dispunham de infra-estruturas técnicas e financeiras que lhes permitissem substituir, nessa função, os antigos proprietários eclesiásticos, reais ou feudais. Mas, principalmente, era-lhes necessário inventar novos usos para os edifícios que haviam perdido sua destinação original - reutilização cujos problemas podemos imaginar, comparando-se àqueles com os quais, apesar de uma longa experiência, ainda hoje nos deparamos. Exemplo: o que se podia fazer com uma igreja? Anexá-la para o culto do Ser Supremo? Essa solução não teve mais sucesso que a tentativa, no fim da Antiguidade, de conversão dos templos pagãos em igrejas cristãs. Seu estilo neoclássico, de acordo com os ideais da Revolução, fez que a igreja Sainte-Geneviève se tornasse, a partir da proposta de Quatremère de Quincy, o 'Panteon francês'. Kersaint propôs, sem sucesso, planos detalhados para a transformação da Madeleine em sede da Assembléia Nacional. Bréquigny sugeriu que se utilizassem, de forma sistemática, as igrejas desativadas como museus. Mas as catedrais e as igrejas que, em muitos casos, haviam perdido seus telhados foram antes convertidas em depósitos de munição, de salitre ou de sal e, dependendo do caso, também em mercados, enquanto os conventos e abadias eram transformados em prisões, como Fontevrault, ou em casernas". Op. Cit, p. 104-105.

${ }^{18}$ Françoise Choay relata que esse processo destruidor suscitara uma reação de defesa imediata, por parte do Estado revolucionário, cujos procedimentos inserem-se no que a autora designou como "conservação secundária ou reacional", que se opõe à "conservação primária ou preventiva", relativa às medidas tomadas desde o início da Revolução para a proteção ordinária do patrimônio nacionalizado. A conservação reacional, verificada na França a partir de 1792, seria "comparável à que foi provocada pelo vandalismo dos reformados na Inglaterra. Contudo, na França em revolução, a 
As instâncias revolucionárias, por meio de seus decretos e "instruções", instituíram uma série de procedimentos auxiliares à conservação desse patrimônio nacional - tais como a classificação das diferentes categorias de bens culturais, móveis e imóveis; o inventário sistemático desses bens; o levantamento do estado de conservação de cada um deles; etc - antecipando, por assim dizer, o aparelho jurídico e técnico de conservação de monumentos históricos que viria a ser desenvolvido mais aprofundadamente na França na década de 1830, por Vitet, Mérimée e pela primeira Comission des Monuments Historiques ${ }^{19}$.

Progressivamente, ao longo do século XIX e no início do século XX, a maioria dos países europeus foi criando seus sistemas normativos próprios de preservação, assim como estruturando órgãos oficiais para esses fins. ${ }^{20}$

Maria Cecília Londres Fonseca, interpretando a própria noção de patrimônio e reflexamente a sua política de preservação - como inseridas em um projeto mais amplo de construção de uma identidade nacional, enumera algumas funções simbólicas exercidas por esse patrimônio preservado, em favor do processo de consolidação dos Estados-nações modernos:

1. reforçar a noção de cidadania, na medida em que são identificados, no espaço público, bens que não são de exclusiva posse privada, mas propriedade de todos os cidadãos, a serem utilizados em nome do interesse público. Nesse caso, o Estado atua como guardião e gestor desses bens;

2. ao partir da identificação, nos limites do Estado nacional, de bens representativos da nação - demarcando-a assim no tempo e no espaço - a noção de patrimônio contribui para objetivar, tornar visível e real, essa entidade ideal que é a nação, simbolizada também por obras criadas expressamente com essa finalidade (bandeiras, hinos, calendário, alegorias e mesmo obras de artistas plásticos, como David). A

postura da reação assume outra dimensão e outro significado, político. Ela agora não visa apenas à conservação das igrejas medievais, mas, em sua riqueza e diversidade, à totalidade do patrimônio nacional". Op. Cit, p. 97.

${ }^{19}$ Françoise Choay, Op. Cit., p.95.

${ }^{20}$ Para um rico levantamento das normas nacionais instituidoras de sistemas e órgãos oficiais de preservação do patrimônio cultural em diversos países europeus, cf. Miguel Brito Correia, Op. Cit, p. 14-15. 
necessidade de proteger esse patrimônio comum reforça a coesão nacional;

3. os bens patrimoniais, caracterizados desde o início por sua heterogeneidade, funcionam como documentos, como provas materiais das versões oficiais da história nacional, que constrói o mito de origem da nação e uma versão da ocupação do território, visando a legitimar o poder atual;

4. A conservação desses bens - onerosa, complexa e frequentemente contrária a outros interesses, públicos e privados - é justificada por seu alcance pedagógico, a serviço da instrução dos cidadãos. ${ }^{21}$.

Ainda segundo esta autora, "a preservação como atividade sistemática só se tornou possível [...] porque ao interesse cultural se acrescentaram um interesse político e uma justificativa ideológica". ${ }^{22}$

$\mathrm{Na}$ América, a presença monumental da civilização pré-colombiana impulsionou o México a publicar pioneiramente uma legislação patrimonial já em 1827, contando este país com uma Junta de Antiguidades desde 1808. Os Estados Unidos publicaram seu Antiquities Act em 1906. Já no Brasil, a sistematização da matéria alcançou o nível legal nacional somente em 1937, como se verá no Capítulo 3 deste trabalho.

Ao mesmo tempo em que essas inovações normativas ocorriam, especialmente nos Estados nacionais europeus, também as atividades práticas de restauro de monumentos foram desenvolvidas nesses diferentes países. Foi a partir das experiências acumuladas com esses restauros que diversas correntes teóricas de intervenção em monumentos foram sendo definidas, influenciando decisivamente o conteúdo de alguns documentos internacionais a partir da década de 1930.

Também, de um modo geral, são perceptíveis nos textos das principais normas internacionais atinentes à matéria mudanças significativas nos fundamentos e nos

\footnotetext{
${ }^{21}$ O patrimônio em processo: trajetória da política federal de preservação no Brasil, p. 59-60.

${ }^{22}$ Op. Cit., p. 60.
} 
meios nacionais de salvaguarda do patrimônio cultural, assim como na própria concepção desse patrimônio.

A seguir, será dado enfoque aos diferentes fundamentos dos quais alguns dos principais documentos internacionais atinentes ao tema lançaram mão para justificar a necessidade de preservação nacional e mesmo internacional do patrimônio cultural.

\subsection{Fundamentos da preservação em documentos internacionais}

A produção de documentos internacionais versando especificamente sobre a preservação do patrimônio cultural é atividade recente na História universal. Entre fins do século XIX e início do século XX, verificam-se as primeiras referências normativas internacionais à proteção de monumentos e edificações - via de regra motivadas pelas ameaças decorrentes de conflitos armados -, assim como os primeiros textos técnicos internacionais de conservação e restauro. ${ }^{23}$

Um dos documentos mais antigos a mencionar explicitamente preocupações com a conservação de bens culturais foi a Declaração de Bruxelas, de 27 de agosto de 1874, dedicada a reger as condutas dos Estados em tempos de guerra. Esta Declaração não chegou a entrar em vigor, mas em seu texto já se consignava a não destruição ou apropriação de estabelecimentos dedicados à instrução, às artes e às ciências, bem como de monumentos históricos e obras de arte, quando da ocupação de territórios de Estados inimigos por autoridades militares. ${ }^{24}$

Em 29 de julho de 1899, por ocasião da conclusão dos trabalhos da primeira Conferência Internacional de $\mathrm{Haia}^{25}$ e sob influência desta Declaração, restou

\footnotetext{
${ }^{23}$ Cf. Miguel Brito Correia, Op. Cit., p. 13-21.

24 “Art. 8. Les biens des communes, ceux des établissements consacrés aux cultes, à la charité et à l'instruction, aux arts et aux sciences, même appartenant à l'Etat, seront traités comme la propriété privée. Toute saisie, destruction ou dégradation intentionnelle de semblables établissements, de monuments historiques, d'oeuvres d'art ou de science, doit être poursuivie par les autorités compétentes". Disponível em http://www.icrc.org/dih.nsf/FULL/135?OpenDocument. Acesso em 15 jan. 2010.

${ }^{25}$ Esta primeira Conferência Internacional de Haia foi realizada no período de 18 de maio a 29 de julho de 1899 e resultou na produção de três Convenções e três Declarações, a saber: I. Convenção para a regulação
} 
convencionado que, nos casos de cercos e bombardeamentos, deveriam ser adotadas todas as medidas necessárias para poupar o máximo quanto possível edifícios dedicados à religião, à arte, à ciência, à assistência, monumentos históricos, hospitais e abrigos de doentes e feridos - desde que, no entanto, eles não estivessem sendo utilizados para fins militares. Também se convencionou que estes edifícios especiais deveriam ser identificados com sinais visíveis e distintivos ${ }^{26}$.

Em 18 de outubro de 1907, na II Conferência Internacional de Haia, as Convenções assinadas em 1899 foram revistas e ampliadas, especialmente para incluir disposições aplicáveis aos casos de guerra naval ${ }^{27}$. Nessa revisão, manteve-se mesma recomendação comentada acima, atinente à conservação de monumentos históricos e de edifícios voltados à religião, arte, ciência, etc, acrescendo-se especificações de tamanho, forma e cores do sinal distintivo a ser colocado nesses edifícios especiais, com vistas a protegê-los também de ataques navais ${ }^{28}$.

Aproximadamente nessa mesma época, as conclusões a que chegaram centenas de participantes do $6^{\circ}$ Congresso Internacional de Arquitetos - realizado em Madri, em abril de 1904, para tratar de variados temas de arquitetura -, ofereceram elementos bastante elucidativos das preocupações de especialistas de diversas nacionalidades com que os Estados garantissem, também em tempos de paz, a

pacífica dos conflitos internacionais; II. Convenção relativa às leis e aos costumes da guerra terrestre; III. Convenção para a adaptação à guerra marítima dos princípios da Convenção de Genebra de 22 de agosto de 1864; IV.1. Declaração concernente à proibição de lançamento de projéteis e de explosivos do alto de balões; IV.2. Declaração relativa à proibição do emprego de de projéteis que tenham por intuito único emitir gases asfixiantes ou deletérios; e IV.3. Declaração referente à proibição de emprego de balas que se introduzem facilmente no corpo humano.

${ }^{26}$ Cf. Conveção relativa às leis e aos costumes da guerra terrestre (Convenção II, de 1899), cujo artigo 27 dispõe o seguinte: "In sieges and bombardments all necessary steps should be taken to spare as far as possible edifices devoted to religion, art, science, and charity, hospitals, and places where the sick and wounded are collected, provided they are not used at the same time for military purposes. The besieged should indicate these buildings or places by some particular and visible signs, which should previously be notified to the assailants”. Disponível em: http://avalon.law.yale.edu/19th_century/hague02.asp. Acesso em: 15 jan. 2010.

${ }^{27}$ Elas passaram a totalizar doze Convenções.

28 "Art. $5^{\circ}$. In bombardments by naval forces all the necessary measures must be taken by the commander to spare as far as possible sacred edifices, buildings used for artistic, scientific, or charitable purposes, historic monuments, hospitals, and places where the sick or wounded are collected, on the understanding that they are not used at the same time for military purposes. It is the duty of the inhabitants to indicate such monuments, edifices, or places by visible signs, which shall consist of large, stiff rectangular panels divided diagonally into two coloured triangular portions, the upper portion black, the lower portion white". Disponível em http://avalon.law.yale.edu/20th_century/hague09.asp. Acesso em: 15 jan. 2010. 
adequada salvaguarda dos monumentos históricos e arquitetônicos contidos em seus territórios:

$1^{\circ}$. Há logar para distinguir duas especies de monumentos: os monumentos pertencentes a um período de civilisação, servindo a usos que já não existem e jamais existirão, e os monumentos que continuam a ser utilizados para o fim para que foram construídos, ou para outros.

$2^{\circ}$. Os monumentos mortos, devem sómente ser conservados consolidando as partes indispensaveis para evitar que caiam em ruinas; porque a importância dum monumento reside no seu valor historico e technico, valor que desapparece com o monumento.

$3^{\circ}$. Os monumentos vivos, devem restaurar-se para que possam continuar a servir, porque em Architectura, a utilidade é uma das bases da belleza.

$[\ldots]$

$6^{\circ}$. Promover-se-á em todos os paizes, onde ainda não existam, a creação de Sociedades de defeza para os monumentos historicos e artisticos; nas nações onde existam, provocar $\left[\right.$ sic ${ }^{\circ}$ seu desenvolvimento, podendo agruparem-se por um esforço commum e collaborarem no estabelecimento do inventário geral das riquezas nacionaes e locaes. ${ }^{29}$

O primeiro documento internacional dedicado exclusivamente ao patrimônio foi produzido somente 27 anos mais tarde, em 1931. Tratava-se da Carta de Atenas sobre o restauro de monumentos, derivada das conclusões gerais da Conferência Internacional sobre a Proteção e a Conservação de Monumentos de Arte e de História $^{30}$, realizada em Atenas, de 21 a 30 de outubro de 1931.

A Carta de Atenas, utilizando-se dos conceitos de algumas correntes teóricas de intervenção em monumentos, discutiu uma série de aspectos que traduziam,

\footnotetext{
${ }^{29}$ (grifamos). Trecho transcrito de Miguel Brito Correia, Op. Cit., p. 16.

${ }^{30}$ Esta Conferência fora organizada pelo Serviço Internacional de Museus - organismo autônomo criado em 1926, no seio do Instituto Internacional de Cooperação Intelectual, que era o órgão técnico de uma das Comissões da Sociedade das Nações -, e teria influenciado a criação da Comissão Internacional dos Monumentos Históricos, considerada por muitos como precursora do atual Conselho Internacional dos Monumentos e dos Sítios - ICOMOS.
} 
naquele tempo, as principais preocupações dos técnicos de conservação e restauro de bens culturais ${ }^{31}$.

As conclusões gerais dessa Conferência ofertaram um conjunto de relevantes princípios aplicáveis às atividades técnicas de conservação e restauro, os quais, pelo ineditismo com que estabelecidos no plano internacional, merecem aqui menção, ainda que de forma resumida:

- Os restauros, quando inevitáveis, deverão respeitar a obra histórica e artística do passado, sem excluir estilos de qualquer época;

- A utilização dos monumentos deve respeitar o seu caráter histórico ou artístico [a fim de assegurar a sua longevidade];

- O interesse da coletividade sobrepõe-se ao interesse privado. Deve ter-se em conta o sacrifício acrescido, exigido aos proprietários, na ótica da preservação do bem comum;

- O caráter e a fisionomia das cidades devem ser respeitados [quando da construção de edifícios], sobretudo nas proximidades dos monumentos;

- É aceite o emprego judicioso de materiais e técnicas modernos, para a consolidação de edifícios antigos;

- Nas condições da vida moderna, os monumentos estão cada vez mais ameaçados pelos agentes atmosféricos, pelo que é necessária a colaboração dos especialistas: físicos, químicos e biólogos;

- O emprego de materiais modernos na conservação de uma ruína deve ser sempre passível de reconhecimento (no sentido de evitar mimetismos);

- Quando se mostrar impossível a conservação de ruínas postas a descoberto por escavações, é aconselhável enterrá-las de novo, para evitar a degradação;

- A conservação dos monumentos exige uma cooperação intelectual universal e deverá constituir um objetivo educacional para a juventude;

- A proteção e conservação dos monumentos exigem normas jurídicas adaptadas a cada país. ${ }^{32}$

\footnotetext{
${ }^{31}$ Hoje, outras doutrinas se desenvolveram e outras preocupações se somaram ao tema, como se verá adiante.
} 
O trecho destacado acima fornece indícios de que, nessa época, a principal ameaça aos monumentos - em tempos de paz - era notadamente os agentes naturais atmosféricos.

Essas conclusões gerais deram origem à Resolução sobre a conservação de monumentos históricos e de obras de arte, aprovada pela Sociedade das Nações em 10 de outubro de 1932. Era, então, a primeira vez que uma norma jurídica de uma organização internacional abordava a questão do patrimônio e reconhecia a sua importância para a humanidade. ${ }^{33}$

De um modo geral, na década de 1930, ainda eram expressivas as preocupações internacionais com a proteção do patrimônio cultural contra os perigos que a guerra lhe representava. A esse respeito dispuseram o Pacto de Washington (ou Pacto de Roerich), assinado em 1935 por 21 nações americanas, e o Anteprojeto de Convenção internacional para a proteção dos monumentos e obras de arte em tempo de guerra (1936), que não chegou a ter aprovação, por conta da eclosão da $2^{\mathrm{a}}$ Guerra Mundial, mas que juntamente com aquele Pacto, influenciaram decisivamente a publicação pela UNESCO, em 1954, da Convenção para a proteção de bens culturais em caso de conflito armado (também conhecida como Convenção de Haia de 1954).

A Convenção de Haia de 1954 derivou da terrível experiência da $2^{\mathrm{a}}$ Guerra Mundial, tendo reconhecido, em seu texto, o efeito devastador dos novos instrumentos bélicos sobre os bens culturais, assim como a necessidade de se organizar medidas efetivas de salvaguarda desses bens em tempos de paz $^{34}$.

\footnotetext{
32 (grifamos). Flavio Lopes, "Evolução do pensamento contemporâneo através da leitura de normas internacionais", In Flavio Lopes; Miguel Brito Correia (org.), Património Arquitectónico e Arqueológico: Cartas, Recomendações e Convenções, p.26-27.

${ }^{33}$ A Carta de Atenas a respeito da qual doravante se discorreu não deve ser confundida com a Carta de Atenas sobre o Urbanismo Moderno, de 1933. Conforme relata Miguel Brito Correia, "a Carta de Atenas sobre o urbanismo moderno foi publicada nos Annales Techniques (órgão oficial da Câmara Técnica da Grécia, sediada em Atenas) no 44-45-46, de Novembro de 1933, e somente em 1943 é publicada em livro pelo grupo CIAM-França, de que Le Corbusier era um dos expoentes”. Op. Cit., p. 22, nota 19. Esta Carta exprime a construção da ideologia Modernista sobre o urbanismo. A partir dos anos 70, todo o movimento moderno é revisto.

34 Flavio Lopes, op. Cit, p. 29. Cf. Preâmbulo da Convenção de Haia de 1954. Disponível em http://portal.unesco.org/publicacoes/docinternacionais/doccultura. Acesso em 12 jul. 2009.
} 
Nesta Convenção, restaram consolidadas as ideias-chaves de que: a) "os danos ocasionados aos bens culturais pertencentes a qualquer povo constituem um prejuízo ao patrimônio cultural de toda a humanidade, dado que cada povo traz a sua própria contribuição para a cultura mundial"; e de que b) "a conservação do patrimônio cultural apresenta uma grande importância para todos os povos do mundo", sendo conveniente "que este patrimônio tenha uma proteção internacional"

Reforçava-se aqui, portanto, a necessidade de se estabelecerem, nos níveis nacional e internacional, medidas de preservação de bens culturais de longo prazo, voltadas para os tempos de paz, com especial fundamento na importância desses bens para a cultura mundial.

Esta justificativa de preservação do patrimônio em razão da relevância deste para a cultura de toda a humanidade - verificada pela primeira vez na Resolução da Sociedade das Nações de 1932 e reiterada nessa Convenção de Haia, de 1954 continuou fortemente presente no pensamento da comunidade internacional. ${ }^{36}$

Assim, na Conferência de Washington, realizada em 1965 pela UNESCO, foi recomendada a criação de um trust para o patrimônio mundial. E em novembro de 1972, foi aprovada por este mesmo organismo a Convenção para a proteção do patrimônio mundial, cultural e natural, cujo alto índice de adesão - quase consensual, posto que mais de 175 dos 189 Estados membros da UNESCO assinaram essa Convenção - demonstra a importância atribuída pelas nações a esse patrimônio universal. Esta Convenção da UNESCO de 1972 será analisada em detalhes no Capítulo 4 deste trabalho.

Depois da $2^{\mathrm{a}}$ Guerra Mundial, os problemas da industrialização e da urbanização em massa passaram a repercutir mais intensamente nas cidades. A ação

35 (traduzimos). Cf. Preâmbulo da Convenção de Haia de 1954. Disponível em http://portal.unesco.org/publicacoes/docinternacionais/doccultura. Acesso em 12 jul. 2009.

${ }^{36}$ Conforme observa Fernando Fernandes da Silva, "Vários são os interesses comuns da humanidade em torno da proteção dos bens culturais: a necessidade de preservar e transmitir às futuras gerações informações a respeito de experiências acumuladas ao longo dos séculos sobre comportamento humano, regimes políticos e econômicos, indispensáveis para a compreensão de fenômenos que afetam a humanidade no presente e no futuro; a utilização dos bens culturais como fonte de deleite e lazer; a necessidade de o homem manter-se ligado aos seus antepassados ou apegar-se a tradições que o remontem a épocas de engrandecimento espiritual ou material da humanidade". As cidades brasileiras e o patrimônio cultural da humanidade, p. 54. 
destruidora de bens culturais tornou-se muito mais vigorosa no meio urbano do que no meio rural. Nesse cenário, em que os agentes atmosféricos já não representavam mais a principal ameaça a esses bens, despertaram-se as consciências para a importância do ambiente ${ }^{37}$ e para a necessidade de formulação de ações preservacionistas voltadas à solução dos problemas de gestão patrimonial presenciados especificamente no meio urbano.

A Carta de Veneza, resultante do II Congresso de Arquitetos e Técnicos de Monumentos Históricos, realizado em maio de $1964^{38}$, já acenava que "o monumento é inseparável da história de que é testemunho e do lugar em que está localizado"39 e que "a conservação de monumentos é sempre favorecida pela sua destinação a uma função útil à sociedade”, que garantirá a constância em sua manutenção ${ }^{40}$.

Com essas assertivas, a Carta de Veneza lançava as bases para o desenvolvimento posterior, pela comunidade internacional, de duas ideias hoje marcantes em matéria de preservação:

Uma primeira, de que os bens culturais imóveis presentes no ambiente urbano não devem ser vistos de maneira isolada, mas sim como inseridos num contexto, ou seja, como parte inerente ao ambiente em que se situam. E uma segunda, de que esses bens, na maioria dos casos, podem ter uma função diversa da originalmente concebida, com vistas a conciliar os interesses de conservação aos anseios de desenvolvimento econômico e social.

Nesse contexto de acelerado crescimento da população nas cidades, Flávio Lopes observa que

\footnotetext{
${ }^{37}$ Fernando Alves Correia, O plano urbanístico e o princípio da legalidade, p. 75.

38 A Carta de Veneza, também intitulada Carta internacional sobre a conservação e o restauro de monumentos e sítios, é considerada por muitos especialistas como o mais importante documento doutrinário e técnico até então elaborado, mantendo uma atualidade notável e servindo, ainda hoje, como base à restante produção normativa do ICOMOS.

${ }^{39} \mathrm{O}$ monumento é concebido pela Carta de Veneza tanto como criação arquitetônica isolada, quanto como conjunto urbano ou rural que dá testemunho a uma civilização particular.

${ }^{40}$ Arts. $4^{\circ}$ e $5^{\circ}$ da Carta de Veneza, 1964. Essa Carta assumiu especial relevância à matéria em razão da noção mais ampliada de monumento histórico adotada em seu texto, que será comentada oportunamente no Capítulo 2 deste trabalho.
} 
[...] o visível fracasso de grande parte das intervenções urbanísticas que suportaram o crescimento acelerado das cidades, despontou um novo sentido de exigência e uma nova esperança: a revitalização dos centros urbanos antigos, com a reutilização do patrimônio edificado existente, e a manutenção da ambiência social dos bairros históricos. ${ }^{41}$

Entre as diversas normas internacionais dispondo sobre estas matérias, destacam-se a Recomendação sobre a salvaguarda dos conjuntos históricos e da sua função na vida contemporânea (ou Recomendação de Nairobi), aprovada pela UNESCO em 1976; e a Carta internacional sobre a salvaguarda das cidades históricas e áreas urbanas históricas (ou Carta de Washington), publicada pelo ICOMOS em 1987.

Na Recomendação de Nairobi, foi ressaltada a importância dos conjuntos históricos ou tradicionais para a sociedade, tendo em vista que eles

[...] fazem parte do ambiente cotidiano dos seres humanos em todos os países; constituem a presença viva do passado que lhes deu forma; asseguram ao quadro da vida a variedade necessária para responder à diversidade da sociedade e, por isso adquirem um valor e uma dimensão humana suplementares;

[...] constituem através das idades os testemunhos mais tangíveis da riqueza e da diversidade das criações culturais, religiosas e sociais da humanidade $[\ldots]$;

[...] adquirem uma importância vital para cada ser humano e para as nações que neles encontram a expressão de sua cultura e, ao mesmo tempo, um dos fundamentos de sua identidade. ${ }^{42}$

Também se reconheceu a rapidez das transformações econômicas e sociais, entendendo-se que a crescente universalidade das técnicas construtivas e das formas arquitetônicas apresentam o risco de uniformização dos povoamentos humanos no mundo inteiro. Em razão desse risco, este documento sugeriu a promoção da

\footnotetext{
${ }^{41}$ Op. Cit., p. 30.

${ }^{42}$ Recomendação de Nairobi. UNESCO, 1976, Considerações Iniciais.
} 
salvaguarda dos conjuntos históricos para evitar a descaracterização ambiental, assim como para desenvolver os valores culturais e sociais peculiares de cada nação ${ }^{43}$.

Como modo de garantia efetiva dessa salvaguarda, recomendou a urgente adoção, por todos os Estados, de uma política global e ativa de proteção e de revitalização dos conjuntos históricos ou tradicionais e de sua ambiência, como parte do planejamento nacional, regional ou local, de forma a orientar a ordenação e o planejamento físico-territorial em todos os níveis. ${ }^{44}$

Por sua vez, a Carta de Washington, publicada pelo ICOMOS em 1987, considerou os conjuntos urbanos como a expressão material da diversidade das sociedades ao longo da história. E, em que pese essa importância dos conjuntos urbanos, eles estariam sendo gravemente ameaçados pela degradação, deterioração e destruição provocadas por um tipo de urbanização característico da era industrial, afetando universalmente todas as sociedades. ${ }^{45}$

Reconheceu-se que essa situação é por vezes dramática e, com vistas a refrear essas potenciais alterações do caráter cultural, social e econômico desses conjuntos urbanos - com perdas irreversíveis para a sociedade-, foram sugeridas neste documento internacional medidas concretas de atuação estatal, nomeadamente a figura do plano de salvaguarda" ${ }^{46}$. Este deveria "integrar-se numa política coerente de desenvolvimento econômico e social e ser tomado em consideração em todos os níveis de planejamento territorial e do urbanismo" 47.

43 Cf. Flávio Lopes, op. Cit., p. 30-31. Cf. também item II.6 dessa Recomendação (Princípios Gerais). Disponível em www.iphan.gov.br. Acesso em 12 jul. 2009.

${ }^{44}$ Assim, dispõe essa Recomendação a esse respeito: "III - Política nacional, regional e local: Em cada Estado membro deveria se formular, nas condições peculiares a cada um em matéria de distribuição de poderes, uma política nacional, regional e local a fim de que sejam adotadas medidas jurídicas, técnicas, econômicas e sociais pelas autoridades nacionais, regionais e locais para salvaguardar os conjuntos históricos ou tradicionais e sua ambiência e adaptá-los às exigências da vida contemporânea. Essa política deveria influenciar o planejamento nacional, regional e local e orientar a ordenação urbana e rural e o planejamento físico-territorial em todos os níveis. As ações resultantes desse planejamento deveriam se integrar à formulação dos objetivos e programas, à distribuição das funções e à execução das operações. Dever-se-ia buscar a colaboração dos indivíduos e das associações privadas para aplicação da política de salvaguarda".

${ }^{45}$ Carta de Washington. ICOMOS, 1987, "Preâmbulo e Definição".

${ }^{46}$ Flávio Lopes, op. Cit., p. 31.

${ }^{47}$ Carta de Washington, ICOMOS, 1987, "Princípios e Objetivos”, artigo $1^{\circ}$. 
Estas duas últimas normas internacionais exprimem um grande avanço teórico em matéria de preservação do patrimônio arquitetônico, consistente no abandono dos princípios da proteção atomizada de monumentos isolados para se passar a compreender todo o tecido urbano.

Essa importância do planejamento como instrumento de conservação e renovação dos centros urbanos antigos também encontrou acolhida na Declaração de Amsterdã e na Carta Europeia do Patrimônio Arquitetônico, ambas publicadas pelo Conselho da Europa, em 1975. De acordo com esta Carta,

O patrimônio arquitetônico dá testemunho da presença da história e de sua importância em nossa vida.

A encarnação do passado no patrimônio arquitetônico constitui um ambiente indispensável ao equilíbrio e ao desenvolvimento do homem.

Os homens do nosso tempo, em presença de uma civilização que muda de feição e cujos perigos são tão manifestos quanto os bons resultados, se apercebem instintivamente do valor desse patrimônio.

É uma parte essencial da memória dos homens de hoje em dia e se não for possível transmiti-la às gerações futuras na sua riqueza autêntica e em sua diversidade, a humanidade seria amputada de uma parte da consciência de sua própria continuidade.

O patrimônio arquitetônico é um capital espiritual, cultural, econômico e social cujos valores são insubstituíveis.

Cada geração dá uma interpretação diferente ao passado e dele extrai novas ideias. ${ }^{48}$

Reconheceu-se também, nessa Carta, que somente mediante a gestão integrada dos bens patrimoniais, com a concertação de esforços entre todos os intervenientes nos processos de ordenação do território e a disponibilização dos meios

${ }^{48}$ Extraído da versão da Carta do Patrimônio Arquitetônico Europeu disponível em www.iphan.gov.br. Acesso em 12 jul. 2009. 
adequados, é possível alcançar resultados satisfatórios ${ }^{49}$. Esclareceu-se, nessa ocasião, que a conservação integrada

- Deve constituir uma das primeiras metas dos projetos de planejamento urbano e regional;

- Atinge-se através da aplicação conjugada de técnicas adequadas de restauro e da escolha correta de funções apropriadas; e

- Carece de suporte legal, administrativo, financeiro e técnico. ${ }^{50}$

Não obstante todo esse desenvolvimento teórico quanto aos fundamentos a justificarem as ações preservacionistas nacionais e internacionais do patrimônio cultural, assim como quanto aos meios de assim fazê-lo, na prática, ainda se observam muitos conflitos de interesses, assim como outros impasses à implementação dessas ideias, que necessitam ser superados.

${ }^{49}$ Flávio Lopes, op. Cit., p. 32-33.

${ }^{50}$ Idem, Ibidem, p. 32-33. 


\section{Capítulo 2 O QUE PRESERVAR?}

For many years, only major monuments were protected and restored and then without reference to their surroundings. More recently it was realised that, if the surroundings are impaired, even those monuments can lose much of their character. Today it is recognized that entire groups of buildings, even if they do not include any example of outstanding merit, may have an atmosphere that gives them the quality of works of art, welding different periods and styles into a harmonious whole. These groups should also be preserved.

Carta do Patrimônio Arquitetônico Europeu ${ }^{51}$

\subsection{A noção de patrimônio cultural nos documentos internacionais}

Já se comentou que, de um modo geral, os conceitos e doutrinas internacionais envolvendo a matéria de preservação do patrimônio arquitetônico sofreram mudanças significativas ao longo dos tempos. Por exemplo, durante o século $\mathrm{XX}$, assistiu-se a um alargamento gradativo da noção de patrimônio cultural veiculada nas Cartas, Convenções, Resoluções e Recomendações publicadas por entidades internacionais como a UNESCO, o ICOMOS, o Conselho da Europa, etc.

De início, a preocupação manifestada nesses documentos centrava-se basicamente nos monumentos isolados, dotados de "importância excepcional" notadamente histórica e arquitetônica. As Convenções de Haia de 1899 e 1907 e a Carta de Atenas de 1931 são bastante elucidativas dessa atenção voltada a este tipo específico de bem cultural.

${ }^{51}$ Conselho da Europa, 1975. 
Grosso modo, prevaleciam as preocupações com a conservação desses monumentos, em detrimento de tudo quanto estivesse no seu entorno e que pudesse ofuscar a sua suntuosidade.

Mesmo quando se recomendou, no texto da Carta de Atenas, o respeito ao caráter e à fisionomia da vizinhança dos monumentos antigos ${ }^{52}$, restava claro ali que a importância dada à ambiência devia-se ao interesse de se conferir maior destaque a estes, funcionando aquela, portanto, como elemento acessório, adjetivo dos monumentos, e não exatamente como patrimônio cultural, isto é, como o próprio objeto da preservação.

Na Convenção de Haia de 1954, estabeleceu-se pela primeira vez no nível normativo internacional uma definição para "bens culturais", ainda restrita ao universo material. Assim, dispôs seu artigo $1^{\circ}$ que

Para os fins da presente Convenção, são considerados como bens culturais, qualquer que seja sua origem e seu proprietário:

a) Os bens, móveis ou imóveis, que tenham uma grande importância para o patrimônio cultural dos povos, tais como os monumentos de arquitetura, de arte ou de história, religiosos ou seculares, os campos arqueológicos, os grupos de construções que por seu conjunto ofereçam um grande interesse histórico ou artístico, as obras de arte, manuscritos, livros e outros objetos de interesse histórico, artístico ou arqueológico, assim como as coleções científicas e as coleções importantes de livros, de arquivos ou de reproduções dos bens antes definidos;

b) Os edifícios cuja destinação pricipal e efetiva seja conservar ou expor os bens culturais móveis definidos na alínea $a$ ), tais como os museus, as grandes bibliotecas, os depósitos de arquivos, assim ocmo os refúgios destinados a proteger em caso de conflito armado os bens culturais móveis definidos na alínea $a$ );

52 Cf. item III das Conclusões Gerais da Carta de Atenas. Flavio Lopes; Miguel Brito Correia (org.), Património Arquitectónico e Arqueológico: Cartas, Recomendações e Convenções, p. 44. 
c) Os centros que contenham um número considerável de bens culturais definidos na alínea a) e b), que se denominarão 'centros monumentais'. 53

Foi com o advento da Carta de Veneza, em 1964, que restou consagrada uma concepção mais ampliada de monumento, que passou a abranger

a criação arquitetônica isolada, bem como o sítio, rural ou urbano, que constitua testemunho de uma civilização particular, de uma evolução significativa ou de um acontecimento histórico. Esta noção aplica-se não só às grandes criações mas também às obras modestas do passado que adquiriram, com a passagem do tempo, um significado cultural. ${ }^{54}$

Esta Carta não somente anunciou um novo modo de visão contextual do patrimônio - na medida em que admitiu hipóteses de tratamento não isolado do monumento -, como também consolidou-se, ela própria, como um marco na substituição do critério da excepcionalidade pelo da referencialidade dos bens integrantes do patrimônio cultural.

Tomado o conjunto de normas internacionais sobre preservação de bens culturais produzidas contemporânea e posteriormente à Carta de Veneza, é perceptível o modo como o pensamento sobre o tema evoluiu gradativamente no sentido de incorporar novos conceitos e critérios, baseados em outras áreas do conhecimento, como a antropologia e a sociologia. A ponto de hoje, a expressão patrimônio cultural revelar uma concepção extremamente ampla, incorporadora de diferentes categorias de bens e mais aproximada da cultura popular e das manifestações cotidianas dos indivíduos do que a aquela concepção recorrente no início do século XX.

Exemplo emblemático desse alargamento da noção de patrimônio é o fornecido pela Declaração do México - publicada pelo ICOMOS em 1985, como

\footnotetext{
${ }^{53}$ (traduzimos). Disponível em: http://portal.unesco.org/publicacoes/docinternacionais/doccultura. Acesso em 20 jul. 2009.

${ }^{54}$ (grifamos). Art. $1^{\circ}$ da Carta de Veneza. Extraído de versão em português coletada em Flavio Lopes; Miguel Brito Correia (org.), Património Arquitectónico e Arqueológico: Cartas, Recomendações e Convenções, p. 103-108.
} 
resultado da Conferência Mundial sobre as Políticas Culturais -, em que restou reconhecido que

o patrimônio cultural de um povo compreende as obras de seus artistas, arquitetos, músicos, escritores e sábios, assim como as criações anônimas surgidas da alma popular e o conjunto de valores que dão sentido à vida. Ou seja, as obras materiais e não materiais que expressam a criatividade desse povo: a língua, os ritos, as crenças, os lugares e os monumentos históricos, a cultura, as obras de arte e os arquivos e bibliotecas. ${ }^{55}$

Por outro lado, essa realidade atual de ampliação do conteúdo do patrimônio cultural impõe grandes desafios aos Estados no tocante ao cumprimento das tarefas de seleção oficial dos bens sujeitos à tutela especial e de definição dos modos mais apropriados de gestão para cada caso, dada a escassez de recursos humanos e financeiros para dar conta de um repertório cada vez mais vasto e diversificado.

No campo específico do patrimônio cultural urbano, são diversos os textos internacionais que vêm enriquecendo o seu conteúdo, podendo ser aqui citados, numa ordem razoavelmente evolutiva:

a) A Recomendação da UNESCO sobre a salvaguarda da beleza e do caráter das paisagens e dos sítios, que já em 1962 ressaltara a importância científica e estética dos sítios e paisagens, bem como o caráter fundamental destes nas condições de vida das populações.

b) A Carta do Patrimônio Arquitetônico Europeu, do Conselho da Europa, 1975, que oferece e consolida uma concepção dinâmica e abrangente de patrimônio arquitetônico, da qual nos valemos, nesta tese, para firmar nossa própria concepção de patrimônio cultural urbano. De acordo com esta Carta, o patrimônio arquitetônico europeu é constituído não somente pelos monumentos que lhe são mais importantes, mas também pelos conjuntos de construções mais modestas de suas cidades antigas e aldeias

\footnotetext{
${ }^{55}$ Isabelle Cury (org.), Cartas Patrimoniais, p. 314-315.
} 
tradicionais inseridas nas suas envolventes naturais ou construídas pelo homem. Nos termos desta Carta:

Durante muitos anos só se protegeram e restauraram os monumentos mais importantes e sem levar em conta a ambiência destes. Mais recentemente, percebeu-se que se a ambiência estiver debilitada, mesmo aqueles monumentos poderão perder muito do seu caráter.

Hoje reconhece-se que grupos inteiros de edifícios, mesmo não contendo nenhum valor excepcional, podem criar uma atmosfera que lhes atribui a qualidade de obras de arte, unindo diferentes períodos e estilos em um harmonioso conjunto. Esses grupos de edifícios também devem ser preservados.

c) A já comentada Recomendação sobre a salvaguarda dos conjuntos históricos e da sua função na vida contemporânea, (ou simplesmente Recomendação de Nairobi), aprovada pela UNESCO em 1976, que tratou de definir como "conjuntos históricos ou tradicionais" os assentamentos humanos cuja coesão e cujo valor são relevantes do ponto de vista cultural. E como "ambiência" desses conjuntos históricos ou tradicionais, entendeu ser "o quadro natural ou construído que influi na percepção estática ou dinâmica desses conjuntos, ou a eles se vincula de maneira imediata no espaço, ou por laços sociais, econômicos ou culturais" $" 56$.

d) A Carta de Florença sobre a salvaguarda dos jardins históricos, elaborada pelo ICOMOS em 1981, a qual, reconhecendo o valor cultural e a particular natureza destes jardins - como "composição arquitetônica cujo material é essencialmente vegetal, e portanto vivo, perecível e renovável" -, aconselhou que eles fossem tutelados mediante o tratamento integrado dos planos de salvaguarda com os de uso do solo e de ordenação do território.

e) A Resolução 813 sobre a arquitetura contemporânea, adotada há mais de vinte e cinco anos pelo Conselho da Europa (exatamente desde 1983), que, preocupada com o patrimônio do futuro, interessantemente chamou a atenção "para a

\footnotetext{
${ }^{56}$ Flavio Lopes; Miguel Brito Correia (org.), Património Arquitectónico e Arqueológico: Cartas, Recomendações e Convenções, p. 175-187.
} 
necessidade de integrar a construção contemporânea, de caráter humano e com qualidade no conjunto arquitetônico existente, de modo a assegurar uma certa continuidade da tradição arquitetônica"57. Nesta Resolução, verifica-se um extraordinário alargamento da noção de patrimônio cultural à universalidade das estruturas construídas na cidade e à qualidade de vida das populações. Como bem avaliado por Flavio Lopes,

este olhar para o presente e para o futuro, preconizando uma maior atenção à arquitetura contemporânea é um sinal de negação das correntes mais conservadoras, defensoras de uma quase cristalização das áreas de acentuado valor patrimonial ${ }^{58}$.

f) A também já referida Carta sobre a salvaguarda das cidades históricas (ou Carta de Washington), do ICOMOS, de 1987, que reconhece nos núcleos urbanos, mais do que simples documentos históricos, representações dos verdadeiros valores das civilizações urbanas tradicionais.

g) A Recomendação $R$ (91) 13 para a proteção do patrimônio arquitetônico do século XX, publicada em 1991 pelo Conselho da Europa, a qual, ainda que de alcance restrito aos países do continente europeu, demonstra-se relevante para o mundo todo, como exemplo de atenção dispensada a um patrimônio que "ainda não envelheceu", mas que já sofre sérios riscos de aniquilamento, justificando-se assim sua salvaguarda no presente, para garantir às gerações futuras o conhecimento e usufruto deste instante da memória europeia.

h) A Carta sobre o patrimônio construído vernáculo, aprovada pelo ICOMOS em 1999, relevante por reconhecer as tradições construtivas desenvolvidas pelas próprias comunidades e transmitidas de maneira informal aos seus descendentes como valores dignos e necessitados de salvaguarda, especialmente em razão das ameaças de homogeneização cultural e arquitetônica existentes no mundo todo. Esta Carta

\footnotetext{
${ }^{57}$ Flavio Lopes; Miguel Brito Correia (org.), Património Arquitectónico e Arqueológico: Cartas, Recomendações e Convenções, p. 201-203.

58 "Evolução do pensamento contemporâneo através da leitura de normas internacionais", In Flavio Lopes; Miguel Brito Correia (org.), Património Arquitectónico e Arqueológico: Cartas, Recomendações e Convenções, p.36.
} 
enumerou interessantes princípios de conservação desse patrimônio, tais como: (i) a participação de grupos multidisciplinares de especialistas que reconheçam a inevitabilidade das mudanças, assim como a necessidade de respeito à identidade cultural; (ii) o respeito aos valores culturais e ao caráter tradicional de edifícios, conjuntos e assentamentos vernáculos, quando necessárias intervenções contemporâneas; (iii) a manutenção e preservação dos conjuntos e assentamentos de caráter representativo em cada uma das áreas, como modo de apreciação e conservação do tradicional; (iv) a consideração do patrimônio vernáculo como parte integrante da paisagem cultural nos programas de conservação e desenvolvimento; e (v) a vinculação do patrimônio vernáculo não só aos elementos materiais, edifícios, estruturas e espaços, mas também ao modo como ele é usado e interpretado pela comunidade e às tradições e expressões intangíveis associadas a ele.

Não há dúvidas de que um dos maiores avanços nessa matéria foi o abandono dos princípios da proteção atomizada de monumentos, para passar a abranger todo o tecido urbano. Esse novo modo de preservação deve-se à necessidade de adaptações a essa alargada concepção de patrimônio, reconhecendo-se também que o ambiente urbano é naturalmente sujeito a transformações de suas feições. Conforme sintetizado por Flávio Lopes,

\footnotetext{
Ultrapassa-se o nível de preocupação sobre o monumento ou sobre a estrutura física, para abarcar 'as relações entre a cidade e o ambiente envolvente natural ou criado pelo homem e para tentar preservar as diferentes funções da cidade, adquiridas ao longo da sua história ${ }^{, 59}$.
}

Existem inúmeras abordagens ambientalistas e ecologistas do tema, depreendendose uma visão globalizante do patrimônio cultural urbano e tentando-se, com isso, fazer frente às rápidas e profundas alterações sentidas no ambiente urbano. Essas recentes concepções dinâmicas, como dito, exigem a superação de novos desafios, tentando-se encontrar a justa medida nas intervenções.

\footnotetext{
${ }^{59}$ Flávio Lopes, op. Cit, p. 31
} 


\subsection{A concepção jurídica de patrimônio cultural segundo a Constituição Federal de 1988}

No Direito brasileiro, o patrimônio cultural vem atualmente definido no artigo 216 da Constituição Federal de 1988, que estabelece:

Art. 216. Constituem patrimônio cultural brasileiro os bens de natureza material e imaterial, tomados individualmente ou em conjunto, portadores de referência à identidade, à ação, à memória dos diferentes grupos formadores da sociedade brasileira, nos quais se incluem:

I -as formas de expressão;

II - os modos de criar, fazer e viver;

III - as criações científicas, artísticas e tecnológicas;

IV - as obras, objetos, documentos, edificações e demais espaços destinados às manifestações artístico-culturais;

V - os conjuntos urbanos e sítios de valor histórico, paisagístico, artístico, arqueológico, paleontológico, ecológico e científico.

Antes do advento dessa Constituição, contava-se com a conceituação jurídica de patrimônio oferecida pelo caput e pelos parágrafos $1^{\circ}$ e $2^{\circ}$ do artigo $1^{\circ}$ do Decretolei $n^{\circ} 25 / 37$, a saber:

Art. $1^{\circ}$. Constitui o patrimônio histórico e artístico nacional o conjunto dos bens móveis e imóveis existentes no país e cuja conservação seja de interesse público, quer por sua vinculação a fatos memoráveis da história do Brasil, quer por seu excepcional valor arqueológico ou etnográfico, bibliográfico ou artístico.

$\S 1^{\circ}$ Os bens a que se refere o presente artigo só serão considerados parte integrante do patrimônio histórico e artístico brasileiro depois de inscritos separada ou agrupadamente num dos quatro Livros do Tombo de que trata o art. $4^{\circ}$ desta lei. 
$\S 2^{\circ}$ Equiparam-se aos bens a que se refere o presente artigo e são também sujeitos a tombamento os monumentos naturais, bem como os sítios e paisagens que importe conservar e proteger pela feição notável com que tenham sido dotados pela natureza ou agenciados pela indústria humana.

Da leitura desses trechos, constata-se que comparativamente ao que até então era previsto pelo Decreto-lei $n^{0}$ 25/1937, a Constituição de 1988 inovou no tratamento dispensado ao tema da preservação do patrimônio cultural em pelo menos dois aspectos.

Primeiramente, ao elevar para o plano constitucional a concepção de patrimônio cultural, tendo o constituinte optado até mesmo por citar alguns exemplos de bens integrantes desse patrimônio, ao que parece, para que não pairassem dúvidas quanto à maior extensão da referida expressão.

Tal iniciativa indica uma clara preocupação do constituinte com que este patrimônio, nas dimensões ali traçada, seja reconhecido como um direito difuso, constitucionalmente garantido. Confere, assim, a essa norma - assim como às previstas nos parágrafos $1^{\circ}$ a $6^{\circ}$ desse mesmo $\operatorname{artigo~}^{60}$-, estabilidade, já que somente modificável por processo especial, assim como superioridade, em relação às normas infraconstitucionais.

Em segundo lugar, a Constituição de 1988 inovou ao dedicar definiçãa jurídica muito mais ampla para o que, a partir de então, passou a denominar com precisão

\footnotetext{
${ }^{60}$ A conceituação do patrimônio cultural brasileiro feita no caput do art. 216 da Constituição de 1988 permite o balizamento da diretiva estatal de preservação, incentivo e valorização dos bens integrantes desse acervo. Tal diretiva vem pormenorizada nos parágrafos deste dispositivo nos seguintes termos:

“\$1º . Poder Público, com a colaboração da comunidade, promoverá e protegerá o patrimônio cultural brasileiro, por meio de inventários, registros, vigilância, tombamento e desapropriação, e de outros modos de acautelamento e preservação.

$\S 2^{\circ}$ Cabem à administração pública, na forma da lei, a gestão da documentação governamental e as providências para franquear sua consulta a quantos dela necessitem.

$\S 3^{\circ}$. A lei estabelecerá incentivos para a produção e o conhecimento de bens e valores culturais.

$\S 4^{\circ}$. Os danos e ameaças ao patrimônio cultural serão punidos na forma da lei.

$\S 5^{\circ}$. Ficam tombados todos os documentos e os sítios detentores de reminiscências históricas dos antigos quilombos."
} 
patrimônio cultural brasileiro, numa clara assunção de uma visão abrangente do universo patrimonial. ${ }^{61}$

Conforme verificado no primeiro trecho transcrito acima, o constituinte de 1988 entendeu como dignos de tutela especial pela ordem jurídica brasileira os bens materiais $^{62}$ ou imateriais ${ }^{63}$, tomados em conjunto ou isoladamente - eleitos pelos diferentes grupos formadores da sociedade brasileira como portadores de referência à sua identidade, à sua ação e à sua memória.

Note-se que, com essa medida, a Constituição Federal de 1988 passou a conferir explicitamente a esses diferentes grupos sociais a titularidade do direito à proteção do patrimônio cultural brasileiro. Essa idéia vem reforçada pelo parágrafo $1^{\circ}$ do artigo 216, que prevê a colaboração da comunidade nas atividades de promoção e de proteção desse patrimônio.

Assim, assumindo um viés claramente democrático quanto ao conteúdo do patrimônio cultural, essa nova definição constitucional suplantou concepção mais antiga, contida no Decreto-Lei $n^{\circ}$ 25/37, de um "patrimônio histórico e artístico nacional" designado pelo Estado a partir de concepções oficiais dos "fatos memoráveis da história" e dos "valores excepcionais" merecedores de proteção ${ }^{64}$.

E confirmou o completo abandono da idéia de inscrição do bem no Livro do Tombo - ou seja, do tombamento daquele - como requisito indispensável para a constituição do direito à tutela estatal do referido bem. Tanto é que, em reforço a essa

\footnotetext{
${ }^{61}$ José Afonso da Silva analisa como adequada a expressão patrimônio cultural brasileiro, empregada pela Constituição de 1988, por sintetizar tanto a idéia de patrimônio histórico, quanto a de patrimônio artístico. Tanto a do patrimônio reconhecido pela União, como a do patrimônio reconhecido pelos Estados e pelos Municípios. Apesar desse aperfeiçoamento, o autor ressalta que a terminologia constitucional ainda é imprecisa, causando algumas vacilações, como por exemplo o uso das expressões patrimônio histórico, cultural, artístico, turístico e paisagístico, e patrimônio histórico-cultural local, nos arts. 24, VII e 30, IX, respectivamente. (Ordenação Constitucional da Cultura, pp. 100 e 101).

${ }^{62}$ Como as imagens sacras de Aleijadinho, o Palácio Imperial de Petrópolis e o conjunto arquitetônico do centro histórico de Salvador, todos tombados pelo IPHAN entre 1938 e 1985 (Processos de tombamento n.845-T-71, 1162-T-85, 822-T-69 e 823-T-69; n. 166-T-38; e n. 1093-T-83 respectivamente).

${ }^{63}$ Tais quais o ofício das paneleiras de Goiabeiras, no Espírito Santo; a celebração religiosa Círio de Nossa Senhora de Nazaré, em Belém do Pará; e o Frevo, registrados pelo IPHAN em 2002, 2004, e 2007 respectivamente.

${ }^{64}$ Art. $1^{\text {o }}$ do Decreto-Lei n. 25/37.
} 
prescindibilidade do tombamento, o constituinte de 1988 fez referência expressa a uma série de instrumentos os quais igualmente poderão servir aos fins de designação e proteção dos bens integrantes do patrimônio cultural brasileiro (artigo 216, parágrafo $1^{\circ}$ ).

A propósito, essa nova concepção constitucional do patrimônio cultural brasileiro acompanha a tendência contemporânea de admitir-se a influência das ciências sociais sobre a acepção jurídica do termo ${ }^{65}$. Esta tendência, como já visto, foi objeto de profícuos debates havidos no nível internacional a partir da segunda metade do século XX, tendo-se intensificado nos anos 80, quando amplamente debatida a formulação do conceito de "patrimônio cultural" com base em princípios inerentes às áreas da antropologia e da sociologia. Conforme já comentado, foi na Declaração do México de 1985, promovida pelo ICOMOS por ocasião da Conferência Mundial sobre as Políticas Culturais, que restou consignada essa influência dessas duas áreas de conhecimento sobre o conceito jurídico de patrimônio cultural, hoje refletida nas Constituições de inúmeros países ocidentais.

Acerca dessa influência sobre o conceito de patrimônio cultural, Sonia Rabello de Castro confirma que:

Tradicionalmente, poder-se-ia conceber que o valor cultural de um prédio, em que estivesse em discussão seu aspecto artístico, envolvesse tão-somente profissionais da área da arquitetura. Hoje, esta visão restrita do bem cultural acha-se ultrapassada, [...].

[...] o trabalho de conceituação do que seja patrimônio cultural exige a participação integrada de outros técnicos, mormente das áreas relacionadas ao estudo do conhecimento epistemológico e filosófico, bem como de áreas de estudo da cultura das sociedades, como a antropologia, a história e demais ciências sociais. Se o fundamental não é a coisa em si, e sim o seu valor simbólico, é importante detectar não só a questão objetiva da arquitetura de um prédio, por

65 José Eduardo Ramos Rodrigues, “A Evolução da Proteção do Patrimônio Cultural - crimes contra o ordenamento urbano e o patrimônio cultural”, In Temas de Direito Público, n. 3, p. 202. 
exemplo, mas sua inserção como valor cultural para um determinado grupo social $^{66}$.

Vê-se que a Constituição de 1988 reconhece de modo inédito o caráter sincrético e multifacetado da cultura brasileira, formada pelas diferentes expressões simbólicas produzidas no seu território, inclusive as de alcance apenas regional ou local. Desmitifica a idéia de uma cultura nacional homogênea, formadora da identidade do Povo Brasileiro, pois impossível universalizar a cultura de um País, especialmente no caso do Brasil, de território tão extenso e de tão expressiva diversidade étnica ${ }^{67}$.

Assim, considera como integrantes do patrimônio cultural brasileiro aqueles bens detentores de um valor simbólico aos diferentes grupos formadores da sociedade brasileira $^{68}$.

O requisito da referencialidade vem previsto na Constituição de 1988 como condição de existência dessa tutela constitucional especial. Com efeito, tratou-se de expressar que nem todas as manifestações culturais constituem o denominado patrimônio cultural brasileiro, mas somente aquelas referenciais, ou seja, aquelas de

${ }^{66}$ O Estado na preservação de bens culturais. O tombamento, pp. 43-44.

${ }^{67} \mathrm{Na}$ avaliação de Alayde Mariani, no tempo em que instituídos o Decreto-lei no 25/37 e, com ele, o conceito jurídico de patrimônio histórico e artístico, vivia-se no Brasil "um momento de orgulho nacional, quando se pretendia projetar e espelhar a feição de uma civilização particular para a nação. [...] A ação nacionalista do Estado Novo, embora integrada ao nacionalismo cultural dos modernistas, não deixava de incorporar outras representações na proposta de criação ou formação do novo homem/povo brasileiro. [...] Construía-se uma pedagogia de formação do brasileiro sob o horizonte do homem ocidental e universal". "A memória popular no registro do patrimônio, In Revista do Patrimônio Histórico e Artístico Nacional. n. 28, 1999, p.158. Essas impressões da autora, todavia, parecem ser refutadas pelas de Maria Cecília Londres Fonseca sobre o mesmo assunto, a qual não obstante reconheça o relevante papel da educação e da cultura no projeto ideológico do Estado Novo, interpreta especificamente as ações do Sphan, órgão nacional de preservação instituído nesse período, como dotadas de autonomia. "A atividade desenvolvida por esse grupo de intelectuais [modernistas] no Sphan gozou de surpreendente autonomia dentro do MES. Desde o início, a área do patrimônio ficou à margem do propósito de exortação cívica que caracterizava a atuação do ministério na área educacional. A cultura produzida pelo Sphan sequer era articulada com os conteúdos dos projetos educacionais ou com os instrumentos de persuasão ideológica do Estado Novo; esses conteúdos eram mais compatíveis com a vertente ufanista do modernismo. Durante o Estado Novo, o Sphan funcionou efetivamente como um espaço privilegiado, dentro do Estado, para a concretização de um projeto modernista". O patrimônio em processo: trajetória da política federal de preservação no Brasil, p. 98.

68 Tais como os terreiros da Casa Branca do Engenho Velho e do Axé Opô Afonjá, em Salvador (tombamentos federais n. 1067-T-82 e n. 1432-T-98); a Basílica Velha de Nossa Senhora de Aparecida, em São Paulo (tombamento estadual n. 22.002/82, resolução n. 11, de 18.04.1982); e o sítio arqueológico na Ilha do Campeche, no Estado de Santa Catarina (tombamento federal n. 1426-T-98), dentre tantos outros exemplos. 
especial importância para a formação da identidade, para a continuação da ação ou para o resgate da memória dos diferentes grupos formadores da sociedade brasileira.

Isso não significa, no entanto, que as manifestações culturais destituídas desse aspecto referencial tenham sido relegadas por completo pela ordem constitucional brasileira. A estas, a Constituição reservou o apoio e o incentivo do Estado à sua valorização e difusão, assim como a garantia do seu livre exercício e de acesso às suas fontes (artigo 215) ${ }^{69}$.

É que especialmente àquelas tidas como referenciais para os diferentes grupos formadores da sociedade brasileira quis-se assegurar tutela jurídica especial, a fim de que, integrando um grande acervo articulado entre as esferas de Poder, essas manifestações culturais pudessem ser preservadas e transmitidas de uma geração para outra.

A Constituição preservou a exigência já verificada na ordem jurídica anteriormente à sua vigência, de designação oficial dos bens integrantes do patrimônio cultural brasileiro. Isso porque uma atuação estatal adequada sobre este patrimônio, seja divulgando-o, seja fomentando-o, seja policiando-o, depende invariavelmente de um conhecimento prévio e preciso do seu conteúdo.

Assim, o parágrafo $1^{\circ}$ do art. 216 exige que o poder público promova o patrimônio cultural brasileiro "por meio de inventários, registros, vigilância, tombamento e desapropriação e de outras formas de acautelamento e preservação".

\footnotetext{
69 “Art. 215. O Estado garantirá a todos o pleno exercício dos direitos culturais e acesso às fontes da cultura nacional, e apoiará e incentivará a valorização e a difusão das manifestações culturais".

$\S 1^{\circ}$. O Estado protegerá as manifestações das culturas populares, indígenas e afro-brasileiras, e das de outros grupos participantes do processo civilizatório nacional.

$\S 2^{\circ}$. A lei disporá sobre a fixação de datas comemorativas de alta significação para os diferentes segmentos étnicos nacionais.

$\S 3^{\circ}$. A lei estabelecerá o Plano Nacional de Cultura, de duração plurianual, visando ao desenvolvimento cultural do País e à integração das ações do poder público que conduzem à:

I - defesa e valorização do patrimônio cultural brasileiro;

II - produção, promoção e difusão de bens culturais;

III - formação de pessoal qualificado para a gestão da cultura em suas múltiplas dimensões;

IV - democratização do acesso aos bens de cultura;

V - valorização da diversidade étnica e regional”.
} 
Conforme será referido oportunamente no Capítulo 4, promover o patrimônio cultural brasileiro, além do sentido de difundi-lo, de divulgá-lo ${ }^{70}$, também sugere o sentido de "formá-lo pela definição de quais bens devem integrá-lo"71. Assim sendo, entende-se que os cinco incisos do art. 216 são apenas indicativos de classes de bens passíveis de constituírem o patrimônio cultural brasileiro, devendo haver, em cada caso concreto, algum ato oficial do poder público para que a tutela especial seja instaurada.

É como também entende Maria Coeli Simões Pires, para quem

o conteúdo dessas expressões [contidas nos cinco incisos do art. 216] haverá de ser definido pelo poder público responsável pela aplicação da lei a partir de condicionamentos e critérios técnicos. As adjetivações não são suficientes para expressar a relação do bem com a cultura para efeito de aplicação da proteção especial ${ }^{72}$.

Da leitura da parte final do caput, fica claro que se trata de enumeração meramente exemplificativa, sendo perfeitamente possível que outras categorias de bens não previstas ali integrem o conteúdo do patrimônio cultural brasileiro, desde que referenciais e assim oficializados pelo poder público.

$\mathrm{O}$ inciso $\mathrm{V}$ trata especificamente dos conjuntos urbanos, bem como dos sítios de valor histórico, paisagístico, artístico, paleontológico, arqueológico, ecológico e científico.

José Afonso da Silva observa com propriedade o modo confuso como o constituinte usou o termo sítio neste inciso, aplicando-o genericamente para uma série de valores, inclusive para valores artísticos e científicos.

Sítios históricos, paisagísticos, arqueológicos, paleontológicos e ecológicos, como locais de ocorrência desses elementos, é expressão

\footnotetext{
${ }^{70}$ Esse sentido é abordado no item 3.1.1. do trabalho.

${ }^{71}$ José Afonso da SILVA, Ordenação Constitucional da Cultura, p. 116.

${ }^{72}$ Da proteção ao patrimônio cultural. O tombamento como principal instituto, p. 83.
} 
corrente; mas 'sítios artísticos e científicos', ao que nos parece, não constitui modo correto de dizer", ${ }^{\text {, }}$.

De efeito, estas últimas expressões não são usuais como o "sítio arqueológico" ou "sítio histórico". São relativamente vazias de significado, pois não é exatamente aos seus locais de ocorrência que esses valores são intrínsecos. Significa dizer que não há uma vinculação inafastável entre esses valores e os sítios onde eles se manifestam.

Afora os bens históricos, artísticos, arqueológicos e paleontológicos, claramente vistos como culturais, não se pode negar este mesmo caráter aos bens paisagísticos, ecológicos e científicos ${ }^{74}$. Aos bens de valor científico, porque expressam a criatividade e a inventividade humana. Aos de valor paisagístico e ecológico, pois mesmo envolvendo aspectos naturais, não necessariamente construídos pelo homem, projetam em sua própria existência valores atribuídos por este, tais como o bem-estar e a boa qualidade de vida. Constituem, por assim dizer, valores subjetivos atribuídos pelo homem à realidade que o circunda.

Lembram Pontier, Ricci e Bourdon que "a própria idéia de conservar no estado de paisagens é um revelador poderoso de uma cultura" ${ }^{\text {"75 }}$. De fato, não fosse o homem querer manter as paisagens e o equilíbrio ecológico, estes poderiam não existir (o que também revelaria um aspecto cultural). É o caso, por exemplo, das intenções de construção de comportas e barragens para conter o avanço gradativo das águas sobre a cidade de Veneza, fator que ameaça o desaparecimento da cidade num tempo futuro.

Vale lembrar, todavia, que tanto para os valores ecológicos como para os valores científicos a Constituição dedicou dispositivos próprios ${ }^{76}$, que muito melhor

\footnotetext{
${ }^{73}$ Ordenação Constitucional da Cultura, p. 122.

${ }^{74}$ Com a ressalva da impropriedade do termo "sítio" para designar bens desta última espécie, conforme apontado acima.

${ }^{75}$ Droit de la culture, p. 322. (traduzimos)

${ }^{76}$ Para bens ecológicos, cf. art. 225, cujo caput, associado aos seus sete incisos e seis parágrafos, oferece rica garantia formal ao meio ambiente ecologicamente equilibrado e estabelece o dever do Estado e da coletividade de preservá-lo e defendê-lo.
} 
exprimem os peculiares interesses de tutela do que a tímida menção feita nesse inciso $\mathrm{V}$ do art. 216.

E no que se refere aos valores científicos, a Constituição de 1988 reservou os arts. 218 e 219, contidos no Capítulo IV ("Ciência e Tecnologia") do Título VIII ("Da Ordem Social"), que garantem a promoção e o incentivo ao desenvolvimento científico, à pesquisa e à capacitação tecnológicas, assim como o estímulo ao mercado interno e à autonomia tecnológica brasileira. 


\section{Capítulo 3 OS MEIOS: QUEM PRESERVA O PATRIMÔNIO CULTURAL URBANO?}

Mas a semente de uma primeira experiência de
política cultural coroada de pleno êxito ficou a
demonstrar que a interferência do Poder
Público no âmbito da cultura, se a prática é
democrática, só pode trazer benefícios,
mormente quando se concebe a cultura como
uma realização da vida social.

José Afonso da Silva ${ }^{77}$

Uma vez explicitados os fundamentos da salvaguarda jurídica do patrimônio cultural urbano e o objeto dessa tutela estatal, este terceiro Capítulo propõe identificar, com ênfase na análise do ordenamento jurídico brasileiro vigente, os sujeitos incumbidos de - ou legitimados a - agir, direta ou indiretamente, no sentido da preservação desse patrimônio.

Preliminarmente à abordagem ora proposta, importa destacar que, de início pouco depois de se ter reconhecido no plano teórico-constitucional o dever do Estado de proteger os objetos de interesse histórico e o patrimônio artístico do País (em 1934) e a partir da primeira sistematização legal da matéria (pelo Decreto-lei $\mathrm{n}^{\circ}$ 25/1937) -, essas atividades de proteção foram desempenhadas, na prática, concentradamente pela União. E desse mesmo modo elas se desenvolveram por um certo período, até que na década de 1960, sinais mais expressivos de uma descentralização de funções puderam ser sentidos.

A configuração atual de participação de diversos atores na promoção e proteção do patrimônio cultural - não somente integrantes da estrutura estatal, mas

77 Ordenação Constitucional da Cultura, p. 223. (Sobre o Departamento de Cultura e Recreação do Município de São Paulo). 
também alheios a ela - decorre, portanto, de um paulatino processo de descentralização das atividades preservacionistas.

Pelo menos dois fatores parecem estar associados a essa ampliação da gama de sujeitos envolvidos com a tutela do patrimônio cultural.

O primeiro deles refere-se à tendência mundial contemporânea de diluição do poder estatal, especialmente no tocante a assuntos envolvendo interesses difusos, como no presente caso. A propósito dessa tendência, observa Agustín Gordillo o seguinte:

É certo que algumas tendências são facilmente discerníveis e alguns autores as viram já na década de 60: a progressiva criação de órgãos supranacionais, de normas supranacionais, de justiça supranacional, com uma simultânea tendência oposta à descentralização ou regionalização do poder dentro de cada país. Acompanha também o processo o crescente desenvolvimento das organizações nãogovernamentais, pessoas jurídicas privadas ou públicas não estatais que realizam atividades de interesse público, mas sem formar parte de organização estatal alguma. Ao seu redor e às vezes na administração pública, aparecem pessoas que desempenham funções públicas sem revestir a qualidade de agentes do Estado. O clássico Estado Nacional se vê assim submetido a tensões opostas, que o têm por quase certo perdedor: perde poder para as regiões estatais internas, perde poder para organizações não-governamentais. Nenhum desses fenômenos é ruim. Ao contrário, é bom que o poder se frature, que haja múltiplos centros de poder, para que existam cada vez menos possibilidades de que alguém, um só, se adone de todo o $\operatorname{poder}^{78}$.

\footnotetext{
78 (traduzimos). No original: "Es cierto que algunas tendencias son fácilmente discernibles y algunos autores las vieron ya en la década del 60: la progresiva creación de órganos supranacionales, de normas supranacionales, de justicia supranacional, con una simultanea tendencia opuesta hacia la descentralización o regionalización del poder dentro de cada país. Acompaña también al proceso el creciente desarrollo de las organizaciones no gubernamentales, personas jurídicas privadas o públicas no estatales que realizan actividades de interés público pero sin formar parte de organización estatal alguna. A su alrededor y a veces en la administración publica, aparecen personas que desempeñan funciones públicas sin revestir la calidad de agentes del Estado. El clásico Estado nacional se ve así sometido a tensiones opuestas, que lo tienen por casi seguro perdedor: pierde poder a mano de las regiones estatales internas, pierde poder a mano de la comunidad estatal supranacional, pierde poder a mano de organizaciones no gubernamentales. Ninguno de estos fenómenos es malo. Es bueno, al contrario, que el poder se fracture, que haya múltiples centros de poder, para que existan cada vez
} 
O segundo fator relacionado à ampliação dos agentes envolvidos com a tutela do patrimônio cultural brasileiro consiste no acelerado crescimento populacional e no vertiginoso processo de urbanização verificados no País em especial a partir do final da década de 1960. Nesse período, o Brasil industrializava-se e suas cidades transformavam-se a olhos vistos, tornando-se em pouco tempo um país predominantemente urbano. As rápidas e pouco qualificadas alterações urbanísticas ameaçavam e destruíam em nova escala o patrimônio cultural, não se fazendo mais suficiente a ação tutelar isolada e exclusiva do órgão federal de preservação. ${ }^{79}$

Assim, se inicialmente, ao longo das décadas de 30 a 50, o Estado Nacional centralizou no Serviço de Patrimônio Histórico e Artístico Nacional - SPHAN praticamente todas as atividades técnicas e políticas de tutela do patrimônio nacional $^{80}$, nas décadas seguintes, os Estados e Municípios passaram pouco a pouco a compartilhar com a União essas ações preservacionistas, agindo especialmente por meio de seus órgãos próprios de preservação.

Essa descentralização das ações de preservação do patrimônio cultural entre os entes federados, a partir da década de 60, significava também uma maior oportunidade de auxílios financeiros para pagamento dos encargos relacionados a essas ações e, consequentemente, uma promessa de melhores condições de se fazer frente às novas e igualmente ampliadas demandas por tutela que surgiam, de um patrimônio que cada vez menos se restringia a monumentos isolados e excepcionais e

menos posibilidades de que alguien, un sólo, se adueñe de todo el poder" Tratado de Derecho Administrativo, Tomo 1, p. IV-32.

${ }^{79}$ Cf. Nestor Goulart Reis Filho, "Por uma nova política de preservação", In O Estado de São Paulo, 9 de janeiro de 2009, p. A2.

${ }^{80}$ É a chamada fase heróica do SPHAN, que segue até o final dos anos 60, coincidindo com a aposentadoria de Rodrigo de Melo Franco de Andrade da diretoria desse Serviço. Excepcionalmente, na década de 1930, verifica-se a organização do Departamento de Cultura e Recreação da Prefeitura Municipal de São Paulo, tendo Mario de Andrade figurado como diretor no período de 1935 a 1937. Não obstante esse órgão, à época, não exercesse atividades voltadas à preservação de monumentos históricos e arquitetônicos, tal qual o SPHAN fazia, é de se reconhecer o valioso e excepcional trabalho que aquele já desenvolvia no município de São Paulo em prol da democratização da cultura, construindo parques infantis, criando o coral paulistano, efetuando levantamentos demográficos, decifrando, conservando e publicando documentos históricos sob sua guarda, incentivando a pesquisa folclórica, a leitura, o resgate da memória de todas as manifestações populares da cidade, etc. Tudo isso visando a elevar a vida cultural de São Paulo, a promover a diversão de crianças e adultos, a dar a devida importância às tradições populares. O Departamento de Cultura ofereceu um contributo inigualável à cultura da cidade de São Paulo, estimulando, já na década de 1930, valores imatériais que somente depois de mais de 50 anos seriam reconhecidos constitucionalmente como expressões de patrimônio cultural. 
que não mais se via ameaçado somente pelo desgaste natural do tempo, mas principalmente pela força da especulação imobiliária.

Mesmo a sociedade civil, de um certo modo, apresentou-se mais marcadamente a essas questões a partir da década de 1970. Também a atuação da comunidade internacional diretamente sobre o patrimônio cultural brasileiro acentuou-se a partir da década de 1980, quando se iniciou a inscrição de uma série de centros históricos brasileiros na Lista do Patrimônio Mundial, com fundamento na Convenção Relativa à Proteção do Patrimônio Mundial, Cultural e Natural da UNESCO, de 1972 .

A atual concepção jurídica de patrimônio cultural brasileiro, conforme comentado no Capítulo 2, já não é a mesma da década de 1930. A Constituição federal de 1988 tratou de ampliá-la, passando a consagrar como tal os "bens [...] portadores de referência à identidade, à ação, à memória dos diferentes grupos formadores da sociedade brasileira", neles incluindo-se as formas de expressão, os modos de criar, fazer e viver, os espaços de manifestações culturais e os conjuntos urbanos (art. 216, caput e incisos I, II, IV e V da Constituição Federal de 1988).

São reconhecidas, portanto, como valores culturais tutelados pelo Poder Público, as manifestações do cotidiano, da vida na cidade, a própria cidade, em si, enquanto artefato significativo das diferentes forças sociais interagentes, assim como suas edificações, inseridas em seus contextos, em seu ambiente e sempre que referenciais à identidade e à memória das comunidades formadoras da sociedade brasileira.

Nota-se que o patrimônio cultural brasileiro, do modo como oficialmente concebido hoje, apresenta-se, ao menos formalmente, muito mais próximo dos valores populares cultivados nos âmbitos local e regional - compatibilizando-se com os anseios e interesses ali manifestados - do que no tempo em que ele era definido juridicamente como o conjunto de bens vinculados a "fatos memoráveis da história do Brasil" ou dotados de "excepcional valor arqueológico ou etnográfico, bibliográfico ou artístico", concepção esta que acabava por privilegiar os valores da cultura erudita, via de regra representativos apenas dos segmentos sociais dominantes. 
Nesse hodierno cenário, a atuação dos poderes públicos municipal e estadual pode contribuir para o exercício da função que mais modernamente tem-se acrescido ao federalismo, de garantia da democracia participativa, "com sua multiplicação de círculos de decisões políticas em que o cidadão fica mais próximo do poder". ${ }^{81}$

A título de argumentação, poder-se-ia defender que a própria comunidade, direta e exclusivamente - e não por meio do Estado -, é quem deveria identificar os valores que lhe fossem significativos e relevantes para a sua memória e para a de seus sucessores e designá-los à tutela jurídica. Esse posicionamento, contudo, traz consigo o risco de que a formação do patrimônio conduzida exclusivamente pela sociedade civil seja tendenciosa para o lado de um ou alguns poucos grupos dominantes da sociedade. É certo que a assunção dessa tarefa exclusivamente pelo Estado também pode ensejar mesmo risco - daí as orientações contemporâneas no sentido de que a comunidade participe das políticas de preservação do patrimônio cultural e de gestão da cidade. Mas a presença do Estado nesse processo é indispensável, como agente condutor de ações e mediador dos interesses em jogo. Também, como definidor e aplicador dos meios coercitivos apropriados à repressão dos abusos e à imposição de limites ao mercado imobiliário.

Portanto, muito embora se reconheça como de fundamental importância a participação da comunidade, a atuação do Estado nessa álea é imprescindível, norteando e induzindo, pela regulação e pelo fomento, o desenvolvimento urbano associado às ações de preservação do patrimônio cultural.

A propósito das organizações internacionais, é de se ressaltar aqui ideia que já se induz da simples leitura dos Capítulos 1 e 2 retro, qual seja, de que ao contrário do que se possa pensar à primeira vista - em razão da distância que parece haver entre questões internacionais e realidades urbanas locais e regionais - , muitas dessas organizações, por meio de suas produções técnicas e normativas, oferecem novos e interessantes modos de se pensar e de se gerir o patrimônio cultural urbano. Nesse aspecto, vale recordar como exemplo o já comentado alargamento nas abordagens desse tema para o nível da globalidade da paisagem. No plano instrumental, a

\footnotetext{
${ }^{81}$ Fernanda Dias Menezes de Almeida, Competências na Constituição de 1988, p. 44.
} 
UNESCO também oferece notável suporte técnico e financeiro para preservação de algumas áreas inseridas nas cidades, quando eleitas segundo critérios específicos como "Patrimônio da Humanidade".

Este Capítulo inicia-se, assim, com a apresentação dos organismos internacionais que têm oferecido contribuições significativas para o tema da preservação do patrimônio cultural no ambiente urbano.

Em seguida, será voltada atenção para o âmbito nacional brasileiro, mas a abordagem não se limitará a uma visão subjetiva vertical da repartição das competências constitucionais atinentes a essa matéria entre os entes federados. Também será analisada horizontalmente a atuação dos três Poderes - Legislativo, Executivo e Judiciário - nessa seara.

Por fim, será analisado o modo como assegurada juridicamente a participação social nos processos de formação e tutela do patrimônio cultural urbano, tendo em vista o comando constitucional no sentido de que a promoção e a proteção deste patrimônio sejam realizadas com colaboração da comunidade (artigo 216, parágrafo $\left.1^{\circ}\right)$.

\subsection{As Organizações Internacionais}

Em função da representatividade e das contribuições de suas produções técnicas e normativas, apontam-se como os organismos internacionais de maior importância para o tema da preservação do patrimônio cultural urbano: a UNESCO, o Centro Internacional de Estudos para a Conservação e o Restauro de Bens Culturais ICCROM, o Conselho Internacional de Monumentos e Sítios - ICOMOS, a Organização dos Estados Americanos - OEA e o Conselho da Europa.

A UNESCO, conhecida como "agência especializada" da ONU, é na realidade organização internacional distinta desta, criada em 1945 e dotada de personalidade 
jurídica própria em direito das gentes ${ }^{82}$, contando atualmente com 193 Estados Membros e 6 Estados Membros associados. Dentre os seus propósitos institucionais, destaca-se o de

\begin{abstract}
manter, expandir e difundir o conhecimento: Garantindo a conservação e a proteção do legado mundial de livros, obras de arte e monumentos de história e de ciência, recomendando as convenções internacionais necessárias às nações envolvidas; Estimulando a cooperação entre as nações em todos os ramos de atividade intelectual, incluindo o intercâmbio internacional de pessoas ativas nos campos da educação, da ciência e da cultura, além do intercâmbio de publicações, objetos de interesse artístico e científico, bem como outros materiais de informação; Desencadeando métodos de cooperação internacional calculados para dar aos povos de todos os países acesso a material impresso e publicado, produzido por qualquer um deles. ${ }^{83}$
\end{abstract}

A maioria das normas internacionais da UNESCO contributivas ao tema já foram comentadas nos Capítulos anteriores, por ocasião da análise dos fundamentos e do objeto da tutela estatal do patrimônio cultural urbano. Referem-se a diretrizes, princípios, evoluções doutrinárias e conceituais de extrema importância no campo teórico. No Capítulo seguinte, será dedicada análise somente à Convenção para a Proteção do Patrimônio Mundial, Cultural e Natural, de 1972, porquanto introdutora e reguladora de um ferramental específico, de assistência direta aos Estados signatários na tutela de sítios naturais e culturais situados em seus territórios, que tenham sido previamente reconhecidos pelo Comitê do Patrimônio Mundial como Patrimônio da Humanidade. No Brasil, existem 16 sítios assim classificados, sendo 8 deles localizados em áreas urbanas ${ }^{84}$.

\footnotetext{
${ }^{82}$ A propósito das agências especializadas da ONU, observa José Francisco Rezek que "sua gravitação em torno das Nações Unidas resulta de uma circunstância de fato: os Estados-membros são praticamente os mesmos, e não há inconveniente em que, reunidos no foro principal, que é a ONU, ali estabeleçam diretrizes de ação para as organizações especializadas". In Direito Internacional Público: Curso Elementar, p. 265.

${ }^{83}$ Art. I.2.c da Constituição da Organização das Nações Unidas para a Educação, a Ciência e a Cultura. UNESCO, 2002. Disponível em: http://unesdoc.unesco.org/images/0014/001472/147273POR.pdf. Acesso em: 10 out. 2009.

${ }^{84}$ Eis os bens culturais brasileiros inscritos na Lista do Patrimônio Mundial: Conjunto Arquitetônico e Urbanístico de Ouro Preto, Minas Gerais (1980), Centro Histórico de Olinda, Pernambuco (1982), Centro
} 
O ICCROM, criado sob os auspícios da UNESCO em 1959 e com sede na Itália, constitui uma organização intergovernamental formada atualmente por mais de 126 Estados membros, tendo o Brasil declarado sua adesão a ele em agosto de 1964. Dentre os seus objetivos está o de incrementar a troca de informação sobre conservação e restauro entre especialistas, tendo colaborado com a produção do intitulado Documento de Nara, de 1994, que sugeriu à UNESCO novas diretrizes quando da aplicação do critério da autenticidade na inscrição de bens culturais na Lista do Patrimônio Mundial.

O ICOMOS é uma organização não governamental sem fins lucrativos que reúne pessoas e instituições de diversas áreas do conhecimento (arquitetura, história, arqueologia, geografia, antropologia, engenharia e urbanismo), especialistas na conservação de monumentos, conjuntos e sítios históricos. Criada em 1965 a partir das resoluções do II Congresso Internacional de Arquitetos e Técnicos de Monumentos Históricos, realizado em Veneza no ano anterior, essa Organização visa ao desenvolvimento e à disseminação mundial de teorias, metodologias e técnicas de conservação específicas para cada tipo de herança cultural, como edificações, cidades históricas, paisagens culturais e sítios arqueológicos ${ }^{85}$. Suas ações até hoje são norteadas pelos princípios preconizados na Carta Internacional sobre a Conservação e o Restauro de Monumentos e Sítios, de 1964 (Carta de Veneza).

O ICOMOS tem produzido vasta documentação técnica sobre o tema (resoluções, declarações, conclusões de encontros, etc), também colaborando com a UNESCO na avaliação das candidaturas de bens culturais à inscrição na Lista do

Histórico de Salvador, Bahia (1985), Santuário de Bom Jesus de Matozinhos, em Congonhas, Minas Gerais (1985), Parque Nacional do Iguaçu (1986), Conjunto Urbanístico de Brasília (1987), Parque Nacional da Serra da Capivara (1991), Centro Histórico de São Luís, Maranhão (1997), Centro Histórico de Diamantina, Minas Gerais (1999), Costa do Descobrimento - Reserva da Mata Atlântica (1999), Mata Atlântica Reservas do Sudeste (1999), Área de Conservação do Pantanal (2000), Parque Nacional do Jaú (2000), Centro Histórico da Cidade de Goiás (2001), Áreas protegidas do Cerrado: Chapada dos Veadeiros e Parque Nacional das Emas (2001), Ilhas Atlânticas Brasileiras: Reservas de Fernando de Noronha e Atol das Rocas (2001).

${ }^{85}$ De acordo com o art. $5^{\circ}$ do seu Estatuto, são propósitos institucionais do ICOMOS: servir como forum de diálogos e troca de experiências profissionais; reunir, desenvolver e disseminar informações sobre princípios, técnicas e políticas de conservação; cooperar com autoridades nacionais e internacionais na implantação de centros de documentação especializados em conservação; auxiliar a adoção e implementação de convenções internacionais relacionadas ao tema; participar da organização de programas de treinamento para especialistas em escala mundial; e fornecer profissionais e especialistas altamente qualificados a serviço da comunidade internacional. 
Patrimônio Mundial. Conforme a natureza do bem envolvido e as medidas protetoras empregadas, o ICOMOS, assim como o ICCROM, poderão colaborar com a UNESCO na prestação de assistência técnica auxiliar à proteção de bens inscritos na Lista do Patrimônio Mundial.

A OEA, sediada em Washington D.C., foi constituída em 1948 e é composta atualmente pelos 35 Estados independentes da América. Dentre os objetivos contidos na sua Carta constitutiva encontra-se o de promover, por meio da ação cooperativa, o desenvolvimento econômico, social e cultural do Continente (art. $2^{\circ}$, alínea $f$ ).

Como produções teóricas da OEA interessantes ao presente tema, destacam-se as Normas de Quito (1967), que reafirmam a ideia de que o espaço é inseparável do conceito de monumento - desenvolvida pela Carta de Veneza (1964) - e a Resolução de São Domingos (1974), que recomenda, dentre outras ações, como forma de compromisso social, que todos os programas de intervenção e resgate dos centros históricos tragam "soluções de saneamento integral que permitam a permanência e melhoramento da estrutura social existente", sugerindo, para tanto, que a salvação desses centros históricos faça parte da política de habitação, levando-se em conta os recursos potenciais que estes possam oferecer.

Por fim, o Conselho da Europa, sediado em Estrasburgo, foi estabelecido em 1949 com o propósito de sugerir aos Estados membros a adoção de ações conjuntas em matérias de âmbito social, econômico, cultural, científico, jurídico e administrativo, de modo a contribuir para uma união mais estreita entre os países europeus, para a defesa da democracia pluralista e dos direitos do homem e para a melhoria das condições de vida.

Dentre os seus objetivos está o de sugerir, no âmbito da cultura, ações que favoreçam a tomada de consciência e a valorização da identidade e da diversidade cultural da Europa.

Atualmente o Conselho da Europa compreende 47 países europeus, sendo relevante a sua contribuição para o tema não apenas em razão dos princípios e filosofias propostos para abordagem do patrimônio, que defendem uma visão ampliada deste, de modo a abarcar também todas as componentes do ambiente 
humanizado e edificado (centros históricos, paisagem cultural, arquitetura dos séculos XIX e XX, etc) ${ }^{86}$, mas sobretudo em razão do reconhecimento de que somente é possível obter resultados satisfatórios de preservação mediante a gestão integrada dos bens patrimoniais, admitindo-se, inclusive, esta forma de conservação como uma das metas principais dos planos urbanísticos ${ }^{87}$.

\subsection{Competências Constitucionais}

A preservação do patrimônio cultural, desde quando prevista pela primeira vez no plano constitucional brasileiro, sempre foi entendida como atribuição estatal exercitável conjuntamente pela União, pelos Estados e pelos Municípios. Assim, a Constituição de 1934, ao introduzir referência à matéria, estabeleceu que

Art. 10. Compete concorrentemente à União e aos Estados

$$
[\ldots]
$$

III - proteger as belezas naturais e os monumentos de valor histórico ou artístico, podendo impedir a evasão de obras de arte;

\section{$[\ldots]$}

Art. 148. Cabe à União, aos Estados e aos Municípios favorecer e animar o desenvolvimento das ciências, das artes, das letras e da cultura em geral, proteger os objetos de interesse histórico e o patrimônio artístico do País, bem como prestar assistência ao trabalhador intelectual.

\footnotetext{
${ }^{86}$ Cf. Convenção Europeia da Paisagem, Conselho da Europa, 2000. Cf. também Flavio Lopes, "Evolução do pensamento contemporâneo através da leitura de normas internacionais", In Flavio Lopes; Miguel Brito Correia (org.), Património arquitectónico e arqueológico..., p. 25 e Rafael Winter Ribeiro, Paisagem Cultural e Patrimônio, p. 50-62.

${ }^{87}$ Flavio Lopes, "Evolução do pensamento contemporâneo através da leitura de normas internacionais", In Flavio Lopes; Miguel Brito Correia (org.), Património arquitectónico e arqueológico..., p. 32. Miguel Brito Correia também ressalta que desde quando publicada sua primeira Convenção versando sobre o patrimônio, o Conselho da Europa já produziu mais de 50 convenções, recomendações e resoluções, afirmando-se, no mundo, "como a instituição mais fecunda na elaboração de instrumentos normativos na área do patrimônio cultural. "Enquadramento histórico das normas internacionais", In Flavio Lopes; Miguel Brito Correia (org.), Património arquitectónico e arqueológico..., p. 19.
} 
Do mesmo modo, as Constituições que se seguiram previram competências comuns para a proteção do patrimônio, atribuídas ora enumeradamente à União, aos Estados e aos Municípios ${ }^{88}$, ora genericamente ao "Poder Público",89, porém nunca pairando dúvidas de que se tratava de tarefa que caberia a todas as entidades federadas cumprir ${ }^{90}$.

Na Constituição de 1988, a inclusão da proteção do patrimônio cultural no rol de competências materiais ${ }^{91}$ comuns, bem como no de competências legislativas concorrentes (artigos 23 e 24 respectivamente) tornou ainda mais claro o quanto já se vinha prescrevendo desde o início à matéria ${ }^{92}$. Dando espaço ao federalismo cooperativo, a preservação do patrimônio cultural brasileiro consagrou-se como questão que interessa a toda a Federação, incumbindo o seu exercício - verdadeiro poder-dever ${ }^{93}$ - indistintamente à União, aos Estados membros, ao Distrito Federal e aos Municípios.

\footnotetext{
${ }^{88}$ De acordo com a Constituição de 1937: “Art. 134. Os monumentos históricos, artísticos e naturais, assim como as paisagens ou os locais particularmente dotados pela natureza, gozam da proteção e dos cuidados especiais da Nação, dos Estados e dos Municípios. Os atentados contra eles cometidos serão equiparados aos cometidos contra o patrimônio nacional."

${ }^{89}$ Consoante a Constituição de 1946: “Art. 174. O amparo à cultura é dever do Estado. [...] Art. 175. As obras, monumentos e documentos de valor histórico e artístico, bem como os monumentos naturais, as paisagens e os locais dotados de particular beleza ficam sob a proteção do Poder Público”. Na Constituição de 1967: “Art. 172. O amparo à cultura é dever do Estado. Parágrafo único. Ficam sob a proteção especial do Poder Público os documentos, as obras e os locais de valor histórico ou artístico, os monumentos e as paisagens naturais notáveis, bem como as jazidas arqueológicas”. Na Emenda Constitucional $\mathrm{n}^{\circ} 1 / 69$, é mantida a redação do art. 172 e parágrafo da Constituição de 1967, alterando-se apenas a numeração para art. 180.
}

90 Toshio Mukai refere-se a esse entendimento Acerca do entendimento de que a expressão "poder público" compreende todos os entes federados, Toshio Mukai manifesta alinhamento com a opinião de Helita Barreira Custódio, expressada nos seguintes termos: "Reafirmando a competência concorrente da União, dos Estados e dos Municípios, em matéria de patrimônio cultural e nacional, a Magna Carta de 1946 adotou de forma mais simplificada a expressão 'poder público', expressão ratificada pela Constituição de 1967 (art. 162 , parágrafo único) e pela Emenda $\mathrm{n}^{\mathbf{0}}$ 1, de 1969 (art. 180, parágrafo único)”. Toshio Mukai, Direito e Legislação Urbanística no Brasil: História, teoria e prática, p. 154.

${ }^{91}$ Também doutrinariamente denominadas competências “executivas” ou "gerais".

${ }^{92}$ Fernanda Dias Menezes de Almeida comenta, inclusive, que teria vindo da Constituição de 1934 a ideia de um rol de competências comuns a mais de uma esfera, e que "o cotejo entre o artigo 23 da atual Constituição e o artigo 10 da de 1934 mostra ter havido a absorção, pelo art. 23, do próprio conteúdo do rol que o art. 10 abrigava". Competências na Constituição de 1988, p. 76.

${ }^{93}$ Consoante ensina Dalmo de Abreu Dallari, a competência não é um poder facultado aos entes federados, mas sim verdadeiro encargo atribuído a eles, um poder-dever o qual o ente não pode se eximir de cumprir. In A reforma constitucional e as novas competências dos Estados e Municípios, p. 32-34. Celso Antonio Bandeira de Mello chega a preferir a expressão "dever-poder" para designar as prerrogativas dos poderes públicos, por entender que assim "se ressalta sua índole própria e se atrai atenção para o aspecto subordinado 
Assim, quanto à competência material, dispõe a Constituição de 1988:

Art. 23. É competência comum da União, dos Estados, do Distrito Federal e dos Municípios:

$[\ldots]$

III - proteger os documentos, as obras e outros bens de valor histórico, artístico e cultural, os monumentos, as paisagens naturais notáveis e os sítios arqueológicos;

IV - impedir a evasão, a destruição e a descaracterização de obras de arte e de outros bens de valor histórico, artístico ou cultural.

Aparentemente voltado ao aspecto natural do ambiente, mas nem por isso não aplicável ao caso em tela, já que empregada expressão ampla, cite-se também o inciso VI do mesmo dispositivo, que igualmente estabelece a competência material comum para "proteger o meio ambiente e combater a poluição em qualquer de suas formas."

O artigo 30, IX dispõe que compete aos Municípios "promover a proteção do patrimônio histórico-cultural local, observada a legislação e a ação fiscalizadora federal e estadual”.

Este dispositivo, à parte as suas contribuições à definição da competência legislativa - como se verá mais adiante -, mostra-se, no plano de competências materiais, mais como um reforço do constituinte de que a preservação do patrimônio cultural é também incumbência do Poder local - ainda mais considerado o histórico brasileiro de, na prática, centralizarem-se as ações preservacionistas nas mãos da União -, do que propriamente como elemento essencial à definição das competências executivas nessa matéria, porquanto, conforme visto acima, já é explícita, no artigo 23, incisos III e IV, a competência comum de todos os Poderes, inclusive dos Municípios.

do poder em relação ao dever". In Curso de Direito Administrativo, p. 72. Essa preferência pela expressão "dever-poder" é compartilhada com Eros Grau e Carmem Lucia de Antunes Rocha, conforme teor dos votos pronunciados no julgamento da Ação Direta de Inconstitucionalidade no 2.544-9/RS, STF, j. 28.06.2006, Min. Rel. Sepúlveda Pertence. 
Essa competência material comum é irrenunciável e indelegável, sendo exemplar, nesse sentido, o acórdão proferido em sede da ação direta de inconstitucionalidade $\mathrm{n}^{\circ}$ 2544-9, proposta pelo Governador do Estado do Rio Grande do Sul, em que se questionou a constitucionalidade da Lei estadual $n^{\circ} 11.380 / 99$, que atribuía aos Municípios do Estado do Rio Grande do Sul os deveres de proteção, guarda e responsabilidade pelos sítios e acervos arqueológicos localizados em seus respectivos territórios.

Nessa ocasião, o Ministro Relator Sepúlveda Pertence ponderou em seu voto que a Lei estadual in casu "não poderia limitar a defesa, proteção e responsabilidade dos sítios arqueológicos a um único ente federativo [...] pois tal disposição ofende diretamente os ditames constitucionais". Mais adiante, acrescentou que "não há possibilidade de se cogitar na exclusão de um ente federativo, em se tratando de competência comum, pelo seu próprio significado - questão de interesse de toda a Federação". Advertiu ainda que as competências previstas no art. 23, III da Constituição de 1988 "substantivam incumbência e responsabilidade [...] de natureza qualificadamente irrenunciável" e que o poder de regulação do modo de cooperação entre elas compete exclusivamente à União, por meio de lei complementar (artigo 23, parágrafo único), o qual, ainda assim, “não abrange o poder de demitirem-se a União ou os Estados dos encargos constitucionais de proteção dos bens de valor arqueológico para descarregá-lo ilimitadamente sobre os Municípios”. Por maioria de votos, o Supremo Tribunal Federal julgou procedente a ação, declarando a inconstitucionalidade da referida lei estadual. ${ }^{94}$

Há, no entanto, na doutrina, autores como Sonia Rabello de Castro que entendem que existiriam "bens que têm importância exclusivamente regional ou local" e que, nessas hipóteses, apenas o Estado, ou o Município, teria interesse jurídico em protegê-los. Também, que faleceria à União competência para agir na

\footnotetext{
${ }^{94}$ ADI 2.544-9/RS, j. 28.06.2006, Min. Rel. Sepúlveda Pertence. O único voto dissidente, do Ministro Marco Aurélio de Mello, pautava-se no fato da lei estadual contestada não ter mencionado expressamente que a atribuição era conferida exclusivamente ao município, entendendo, portanto, que eventual declaração de inconstitucionalidade daria "uma carta em branco aos municípios quanto ao fato de não adotarem providências visando a essa proteção". Deve-se considerar, entretanto, que o dever dos municípios de adotarem tais providências deriva diretamente da Constituição, não se justificando esse "reforço de comando" no nível legal estadual. Ademais, o teor da lei contestada não deixava dúvidas quanto às intenções do Estado de delegar essa atribuição exclusivamente ao município.
} 
proteção de um bem que não tivesse importância para a cultura nacional, por falta de interesse jurídico ${ }^{95}$.

Aproximando-se dessa linha, Antônio Augusto de Queiroz Telles considera que

O que vai [...] disciplinar a atuação do Poder Público, nessa matéria, é justamente a abrangência do sentido histórico ou artístico, situado na escala nacional (União), regional (Estados), ou local (Municípios), além da do Distrito Federal. [...] Para que possa haver concomitância de tombamento, sobre o mesmo bem, seria necessária a comprovação do real interesse das três esferas ${ }^{96}$.

Ousa-se discordar dessas leituras, posto que elas não parecem refletir adequadamente a orientação dada pelo constituinte de 1988 quanto à responsabilidade dos entes federados nessa matéria.

Hely Lopes Meirelles, por ocasião da análise da competência privativa dos Municípios em assuntos de interesse local, já ponderou que "não há assunto municipal que não seja reflexamente de interesse estadual e nacional. A diferença é apenas de grau [de predominância], e não de substância" ${ }^{97}$. Portanto, nem mesmo neste caso de competência privativa dos Municípios existiriam interesses exclusivamente locais.

No que diz respeito à preservação do patrimônio cultural - para a qual, como se viu, foi definida expressamente competência comum -, fica evidente que a matéria interessa a toda a Federação, independentemente de avaliações, no caso concreto, de

\footnotetext{
${ }^{95}$ O Estado na preservação de bens culturais, p. 21 e ss.

96 Tombamento e seu regime jurídico, p. 95. Na mesma linha, cf. Toshio Mukai, Direito e Legislação Urbanística no Brasil, p. 155.

${ }^{97}$ Direito Municipal Brasileiro, p. 131. O autor retoma esse seu entendimento em outra passagem: "Interesse local não é interesse exclusivo do Município; não é interesse privativo da localidade; não é interesse único dos munícipes. Se se exigisse essa exclusividade, essa privatividade, essa unicidade, bem reduzido ficaria o âmbito da Administração local, aniquilando-se a autonomia de que faz praça a Constituição. Mesmo porque não há interesse municipal que não o seja reflexamente da União e do Estado-membro, como, também, não há interesse regional ou nacional que não ressoe nos Municípios, como partes integrantes da Federação brasileira. O que define e caracteriza o 'interesse local', inscrito como dogma constitucional, é a predominância do interesse do Município sobre o do Estado ou da União.” (Grifos do autor). Op. Cit., p. 107.
} 
alguma predominância de interesses locais ou regionais. Com efeito, do que se deduz do teor do artigo 216 , caput e parágrafo $1^{\circ}$ da Constituição de 1988 , todos os valores culturais reconhecidos oficialmente pelo Poder Público - seja pela União, por Estados, pelo Distrito Federal ou por Municípios - como referenciais à sociedade brasileira integram o patrimônio cultural brasileiro, sendo certo que sua preservação às presentes e futuras gerações assume, de algum modo, importância nacional.

Não bastasse essa disposição do artigo 216, o constituinte tratou de incluir o tema no rol do artigo 23, isto é, dentre aquelas matérias de grande relevância social e que reclamam a cooperação executiva de todos os entes federados, nos três níveis, seja por envolverem interesses públicos particularmente ameaçados, seja por demandarem o cumprimento de metas de alcance social nacional ${ }^{98}$. Ainda, no parágrafo único desse mesmo dispositivo, sugeriu que a preservação de valores referenciais à memória à ação ou à identidade das gerações presentes e futuras serve ao "equilíbrio do desenvolvimento e do bem estar em âmbito nacional"99.

Portanto, não se revela adequado entender que qualquer dos entes da Federação esteja isento, em alguma hipótese, da responsabilidade pela preservação desse patrimônio que constitui, todo ele, um bem jurídico nacional. O que se pode definir, em nível infraconstitucional, são atribuições diferenciadas desses entes nessa matéria, na prática, mas não que essa distribuição legal de atividades exclua o dever constitucional comum, de todos eles, por essa preservação ${ }^{100}$.

\footnotetext{
98 Tais como: cuidar da saúde e assistência pública (art. 23, II), proporcionar os meios de acesso à cultura, educação e ciência (inciso V), proteger o meio ambiente (inciso VI), preservar florestas, fauna e flora (inciso VII), promover melhorias na habitação e no saneamento básico (inciso IX), combater as causas da pobreza (inciso X), etc. Cf. Fernanda Dias Menezes de Almeida, Competências na Constituição de 1988, p. 130 e ss.

99 “Art. 23. [...] § único. Leis complementares fixarão normas para a cooperação entre a União e os Estados, o Distrito Federal e os Municípios, tendo em vista o equilíbrio do desenvolvimento e do bem-estar em âmbito nacional".

100 Reforce-se que a realidade dos Municípios brasileiros é de verdadeira carência de recursos próprios. Em pesquisa do IBGE realizada em 2000, apurou-se que aproximadamente $95 \%$ dos 5.198 Municípios pesquisados possuíam mais de $65 \%$ de suas receitas totais provenientes de transferências correntes da União e dos Estados federados respectivos. Ainda assim, nos anos de 2003 a 2005 , os municípios foram as entidades federadas com maior participação no total de despesas governamentais com cultura $(54 \%, 52,3 \%$ e 47,2\%, para os anos de 2003, 2004 e 2005, respectivamente), conforme demonstrado em pesquisa desse mesmo Instituto. Esses dados acabam se tornando mais preocupantes, no que diz respeito aos investimentos públicos em cultura e, por via reflexa, em preservação do patrimônio, quando se comparam os gastos governamentais anuais nesta área com os realizados em outras áreas sociais, como saúde e educação: tomando-se por base o período de 2003 a 2005, o IBGE
} 
Para a execução dessa competência comum de preservação do patrimônio cultural brasileiro, o parágrafo único do artigo 23 da Constituição prevê a edição de lei complementar fixando normas de cooperação entre os entes federados ${ }^{101}$.

Entende-se que esta lei complementar, a que se refere o mencionado dispositivo, deverá fixar as bases políticas e as normas operacionais disciplinadoras do modo como se pretende que as atividades de preservação do patrimônio cultural brasileiro sejam exercidas pelos entes federados. Conforme defendido por Fernanda Dias Menezes de Almeida, a lei complementar que for editada com fundamento no artigo 23, parágrafo único

Dirá, por exemplo, como as Administrações federal, estaduais e municipais e do Distrito Federal deverão colaborar reciprocamente para que não ocorra a dispersão dos esforços que o constituinte quer ver conjugados.

Estabelecerá o norte para a especificação do que compete a cada esfera política na prestação dos mesmos serviços objeto da competência comum. ${ }^{102}$

Em complementação a essa definição dos modos de distribuição e de integração das atribuições executivas nos três níveis da Federação brasileira, também é perfeitamente cabível, no conteúdo dessa lei complementar, o estabelecimento dos instrumentos administrativos passíveis de serem empregados pelos entes federados para os fins de preservação patrimonial. Isso com vistas a se evitar centralização, lacunas e sobreposições de ações, bem como conflitos na aplicação dos instrumentos de preservação pelos entes federados.

apurou que as médias de gastos governamentais anuais (das três esferas de governo) nas áreas da educação e da saúde foram respectivamente de $6,7 \%$ e $6,9 \%$ do total de gastos governamentais anuais. Já na área da cultura, a média percentual de gastos anuais foi de apenas $0,2 \%$, nesses três anos. Para essas e outras informações a esse respeito, cf. tabelas nos Anexos I a V deste trabalho.

101 A Emenda Constitucional $n^{\circ}$ 53/2003 tratou de alterar a redação original desse parágrafo único, substituindo a expressão "lei complementar fixará" por "leis complementares fixarão". Desse modo, restou claro que é possível a edição de lei complementar específica para cada matéria arrolada no artigo 23.

${ }^{102}$ Fernanda Dias Menezes de Almeida, Competências na Constituição de 1988, p. 134. 
No campo ambiental natural, são registrados avanços na tramitação, no Congresso Nacional, do Projeto de Lei Complementar $\mathrm{n}^{\circ} 12-\mathrm{B}$ de 2003, que fixa normas de cooperação entre União, Estados, Distrito Federal e Municípios para o exercício de suas competências comuns relativas à preservação do meio ambiente natural (art. 23, VI), das florestas, fauna e flora (art. 23, VII) e - o que é curioso dentre os interesses reunidos no artigo 23, III (documentos, obras e outros bens de valor histórico, artístico ou cultural, monumentos, paisagens naturais notáveis e sítios arqueológicos), somente as paisagens naturais notáveis. ${ }^{103}$ Aqui, mais uma vez, optou-se por tratar juridicamente o patrimônio ambiental enfatizando-se apenas os seus aspectos de natureza.

Para essa mesma finalidade de execução da competência material comum de preservação do patrimônio cultural, a Constituição de 1988 também admite que sejam celebrados convênios de cooperação entre os entes federados. É o que hoje resta expressamente consentido no artigo 241 da Constituição de 1988 - acrescido pela Emenda Constitucional $n^{\circ} 19 / 1988^{104}$.

Portanto, a elaboração e aprovação de lei complementar não é imprescindível para que se estabeleçam modos de cooperação entre entes federados nessa matéria de preservação do patrimônio cultural. Convênios de cooperação poderão ser celebrados com vistas ao exercício mais vantajoso dessa competência.

\footnotetext{
${ }^{103}$ A redação final do Projeto de Lei Complementar 12-B/2003 foi recentemente aprovada pela Câmara dos Deputados (em 16 de dezembro de 2009), tendo seguido para o Senado Federal na mesma data. Última atualização em dezembro de 2009.

104 Já na Constituição de 1937 existia previsão da possibilidade de associação dos municípios com vistas à realização de atividades prestacionais públicas de forma cooperada. Assim dispunha o artigo 29 desta Constituição: "Os municípios da mesma região podem agrupar-se para a instalação, exploração e administração de serviços públicos comuns. O agrupamento, assim constituído, será dotado de personalidade jurídica limitada a seus fins. Parágrafo único. Caberá aos Estados regular as condições em que tais agrupamentos poderão constituir-se, bem como a forma de sua administração". Também o $\S 3^{\circ}$ do artigo 13 da Constituição de 1969 dispunha que "A União, os Estado e os Municípios poderão celebrar convênios para a execução de suas leis, serviços ou decisões, por intermédio de funcionários federais, estaduais ou municipais". Com a Emenda Constitucional n ${ }^{\circ}$ 19/98, superou-se a omissão da Constituição de 1988 acerca dessa faculdade, que já consistia em verdadeira tradição constitucional, aprovando-se a seguinte redação para o artigo 241 da Constituição de 1988: "Art. 241. A União, os Estados, o Distrito Federal e os Municípios disciplinarão por meio de lei os consórcios públicos e os convênios de cooperação entre os entes federados, autorizando a gestão associada de serviços públicos, bem como a transferência total ou parcial de encargos, serviços, pessoal e bens essenciais à continuidade dos serviços transferidos”. Cf. MEDAUAR, Odete; OLIVEIRA, Gustavo Justino de. Consórcios Públicos: Comentários à Lei 11.107/2005, p. 17-20.
} 
No tocante à competência legislativa em matéria de preservação do patrimônio cultural, a Constituição de 1988 estabelece que:

Art. 24. Compete à União, aos Estados e ao Distrito Federal legislar concorrentemente sobre:

\section{$[\ldots]$}

VII - proteção ao patrimônio histórico, cultural, artístico turístico e paisagístico;

VIII - responsabilidade por dano ao meio ambiente, ao consumidor, a bens e direitos de valor artístico, estético, histórico, turístico e paisagístico;

Ainda que deslocada, a competência legislativa concorrente dos Municípios encontra guarida no artigo 30, II, que lhes incumbe de "suplementar a legislação federal e a estadual no que couber", assim como no artigo 30, IX, já referido acima, que também reforça o caráter suplementar da atividade legislativa municipal ao determinar que a proteção do patrimônio histórico-cultural local deverá observar as legislações estadual e federal.

Estes dispositivos do artigo 24, do mesmo modo que os do artigo 23, traduzem a ênfase dada pela Constituição de 1988 ao federalismo cooperativo em matéria de preservação, à medida que atribuem poderes políticos também aos entes periféricos e sugerem a coordenação das competências legislativas de todos eles de tal modo que sejam definidos graus diferenciados de participação em questões de relevância para toda a Federação ${ }^{105}$. Assim, à União caberia a decisão comum, tomada em escala federal, e aos Estados e Municípios competiria adaptar essa decisão às suas peculiaridades e necessidades regionais e locais, além de executá-la autonomamente.

Pertinente apontamento é feito por Fernanda Dias Menezes de Almeida, concernente à diferença de limites ao exercício das competências legislativas concorrentes em matéria de preservação admitidas na anterior Emenda Constitucional n $1 / 69$ e na atual Constituição de 1988:

${ }^{105}$ Gilberto Bercovici. Desigualdades Regionais, Estado e Constituição cit., p. 151. 
Relativamente à proteção do patrimônio histórico-cultural, que o parágrafo único do artigo 180 da anterior Constituição cometia ao Poder Público em geral, podia-se entender, sob a égide daquela Constituição, que havia competência legislativa cumulativa. Pela atual Constituição, a matéria passa a integrar a competência concorrente não cumulativa ${ }^{106}$.

Significa dizer que, pela Constituição anterior, atribuindo-se o encargo da proteção do patrimônio cultural genericamente ao "poder público", não se estabeleciam limites prévios ao exercício da competência legislativa concorrente pelos entes federados nessa matéria, podendo todos eles, em tese, legislar livremente sobre a proteção especial de documentos, obras, sítios de valor histórico ou artístico, monumentos e paisagens naturais notáveis, bem como as jazidas arqueológicas.

Já pela ótica da Constituição de 1988, a matéria submete-se à repartição vertical de competências, segundo a qual, dentro do mesmo campo material, fica reservado um nível normativo superior à União, para fixação dos princípios e das normas gerais, deixando-se aos Estados-membros e Municípios (artigo 30, II) a complementação dessas normas, de acordo com suas realidades específicas.

Neste segundo caso, portanto, a atividade legiferante dos Estados sofre limitações das normas gerais estabelecidas pela União e a atividade dos Municípios, tanto das normas gerais da União, quanto das normas complementares dos Estados respectivos. É o que esclarecem os parágrafos $1^{\circ}$ a $4^{\circ}$ do artigo 24 da Constituição, que sistematizam, de modo geral, a competência legislativa concorrente não cumulativa. $^{107}$

\footnotetext{
${ }^{106}$ Competências na Constituição de 1988, p. 142. Sobre a competência legislativa concorrente da União, Estados e Municípios em matéria de preservação sob a ótica da Emenda n ${ }^{\circ} 1 / 69$, cf. também Marcelo de Oliveira Fausto Figueiredo Santos. "Tombamento: uma análise constitucional", in Adilson Abreu Dallari e Lúcia Valle Figueiredo (orgs.), Temas de Direito Urbanístico 1, p. 63-64; e Carlos Augusto A. Machado, "Tombamento: um instituto jurídico", in Adilson Abreu Dallari e Lúcia Valle Figueiredo (orgs.), Temas de Direito Urbanístico 1, p. 29-31.

107 “Art. 24. [...] $\$ 1^{\circ}$. No âmbito da legislação concorrente, a competência da União limitar-se-á a estabelecer normas gerais. $\$ 2^{\circ}$. A competência da União para legislar sobre normas gerais não exclui a competência suplementar dos Estados. $\$ 3^{\circ}$. Inexistindo lei federal sobre normas gerais, os Estados exercerão a competência legislativa plena, para atender a suas peculiaridades. $\$ 4^{\circ}$. A superveniência de lei federal sobre normas gerais suspende a eficácia da lei estadual, no que lhe for contrário”.
} 
Procedendo a uma análise crítica do modelo teórico de repartições de competências da Constituição de 1988, Fernanda Dias Menezes de Almeida pondera que

\begin{abstract}
Parece-nos, efetivamente, que a utilização das competências concorrentes $^{108}$, como idealizada, atende aos desígnios de se chegar a maior descentralização, sem prejuízo da direção uniforme que se deva imprimir a certas matérias.
\end{abstract}

Numa palavra, o caminho que se preferiu é potencialmente hábil a ensejar um federalismo de equilíbrio, que depende, embora, como não se desconhece, também de outras providências. ${ }^{109}$

Contudo, um problema apontado na prática dessas competências legislativas concorrentes não cumulativas refere-se justamente à dificuldade de identificação das "normas gerais", dentre as emanadas pela União - as quais, lembre-se, justificariam uma relativa centralização normativa por parte deste ente político.

Esse impasse deve-se, em grande parte, ao problema da formulação de um conceito de "normas gerais" que permita o reconhecimento destas com razoável segurança ${ }^{110}$. De outra parte, as dificuldades de identificação dessas normas são

\footnotetext{
${ }^{108}$ Vale apontar que Fernanda Dias Menezes de Almeida considera a expressão "competência concorrente" como sinônima de "competência comum". Para a autora, as competências concorrentes seriam "competências exercitáveis conjuntamente, em parceria, pelos integrantes da Federação, segundo regras preestabelecidas [...], assim tradicionalmente determinada porque [...] relativamente a uma só matéria concorre a competência de mais de um ente político". Mais adiante, ressalta que "a competência material do art. 23 foi designada como competência 'comum', termo que, no caso, tem o mesmo sentido de 'concorrente". In Competências na Constituição de 1988, p. 129. Ainda em outro trecho, a autora comenta que: "Passando-se às competências comuns, estão elas discriminadas em dois dispositivos. No artigo 23 são previstas [...]. De outra parte, no artigo 24 figura [...]". Op. Cit., p. 75. Em sentido contrário, estabelecendo diferenças entre competências comuns e concorrentes, cf. José Afonso da Silva, Curso de Direito Constitucional Positivo, p. 481 e Gilberto Bercovici, Desigualdades Regionais, Estado e Constituição, p. 153, nota 369.
}

${ }^{109}$ Competências na Constituição de 1988, p. 77.

${ }^{110}$ Referindo-se à orientação de Tércio Sampaio Ferraz Jr., no sentido de que o conteúdo da expressão 'norma geral' seja analisado teleologicamente, Gilberto Bercovici prossegue assinalando o seguinte: "As normas gerais devem se reportar ao interesse fundamental da ordem federativa. Como a Federação brasileira têm [sic] por fundamento a solidariedade, que exige a colaboração de todos os seus integrantes, existe a necessidade de uniformização de certos interesses como base desta cooperação. Desta maneira, toda matéria que ultrapassar o interesse particular de um ente federado porque é comum, ou seja, interessa a todos, ou envolver conceituações que, se fossem particularizadas num âmbito subnacional, gerariam conflitos ou dificuldades nacionalmente, é matéria de "norma geral"'. In Desigualdades Regionais, Estado e Constituição, p. 152. Fernanda Dias Menezes de Almeida cita a advertência de Manoel Gonçalves Ferreira Filho de que, pelo ângulo positivo, a conceituação de "normas gerais" sempre daria margem a dúvidas, no caso concreto, 
agravadas pelo fato delas recorrentemente virem inseridas em um mesmo diploma legal em que também presentes normas específicas à Administração Pública da União, sem maiores sistematizações ou distinções umas das outras.

Esse problema acaba gerando incertezas, na prática, quanto aos precisos limites dos campos autônomos de atuação legislativa estadual, distrital e municipal, podendo suscitar conflitos de competências.

De qualquer forma, diante das exposições feitas até aqui, resta claro, no plano teórico, o modo como a Constituição de 1988 definiu a repartição de competências em matéria de preservação do patrimônio cultural.

Tendo em vista o foco deste trabalho no patrimônio cultural urbano, assim como o fato de que a preservação deste patrimônio é um dos fins da atividade urbanística $^{111}$, cumpre agora analisar sistematicamente as competências constitucionais em direito urbanístico, a fim de se verificar se o quanto definido pela Constituição de 1988 em matéria de preservação do patrimônio cultural encontra harmonia com as disposições igualmente definidas por aquela para o tratamento da ordenação urbana.

Formulada em outros termos, a questão presente é a seguinte: seriam as competências constitucionais em matéria de preservação do patrimônio cultural compatíveis com as competências em matéria urbanística? Ou, pelo contrário, haveria algum conflito entre as disposições atinentes a esses dois temas, tratados separadamente pela Constituição Federal?

Em 1988, foi dedicado pela primeira vez tratamento constitucional sistematizado à questão urbana. No tocante às competências, o constituinte de 1988 tratou de reconhecer esquema que já vinha sendo defendido pela doutrina, no tempo

de até onde ela seria efetivamente geral, razão pela qual este autor sugere que essas normas sejam definidas pelo aspecto negativo, ou seja, identificando as características de uma norma que não seja geral. Fernanda Dias Menezes de Almeida não vê muito como evitar, na prática, relativo subjetivismo na identificação das normas gerais, o que acaba canalizando para conflitos de competências. op. Cit., p. 146-151.

111 A esse respeito, ensina José Afonso da Silva que "é também um momento importante da atividade urbanística a preservação do meio ambiente natural e cultural, assegurando, de um lado, condições de vida respirável e, de outro, a sobrevivência de legados históricos e artísticos e a salvaguarda de belezas naturais para desfrute e deleite do Homem". Direito Urbanístico Brasileiro, p. 33. 
do regime anterior - ainda que com relativa dificuldade, dado o silêncio constitucional de então -, no sentindo de incumbir tanto a União, como os Estados, o Distrito Federal e os Municípios dos assuntos urbanísticos.

De acordo com a atual Constituição, à União cabe editar normas gerais de direito urbanístico (artigo 24, I e parágrafo $1^{\circ}$ ) ${ }^{112}$, além de "elaborar e executar planos nacionais e regionais de ordenação do território e de desenvolvimento econômico e social" (artigo 21, IX) e "instituir diretrizes para o desenvolvimento urbano, inclusive habitação, saneamento básico e transportes urbanos" (artigo 21, XX).

Estas duas últimas competências são, ao mesmo tempo, materiais - ou seja, de execução - e legislativas, tendo em vista o teor do artigo 48, inciso IV da Constituição Federal $^{113}$.

Elas traduzem não somente uma vinculação adequada entre os planos de ordenação do território e os de desenvolvimento econômico e social ${ }^{114}$, como também uma clara intenção do constituinte de ressaltar o papel de destaque da União em matéria de planejamento. Ambas as ideias são reforçadas pelo teor do caput e do parágrafo $1^{\circ}$ do artigo 174, que mesmo não mencionando expressamente a competência própria da União para as funções estatais ali referidas, não deixam dúvidas de que ela a possua.

Art. 174. Como agente normativo e regulador da atividade econômica, o Estado exercerá, na forma da lei, as funções de fiscalização, incentivo e planejamento, sendo este determinante para o setor público e indicativo para o setor privado.

\footnotetext{
112 “Art. 24. compete à União, aos Estados e ao Distrito Federal legislar concorrentemente sobre: I - direito [...] urbanístico. $\$ 1^{o}$ No âmbito da legislação concorrente, a competência da União limitar-se-á a estabelecer normas gerais".

${ }^{113}$ De acordo com o art. 48, IV da Constituição de 1988: “Cabe ao Congresso Nacional, com a sanção do Presidente da República, não exigida esta para o especificado nos arts. 49, 51 e 52, dispor sobre todas as matérias de competência da União, especialmente sobre: [...] IV - planos e programas nacionais, regionais e setoriais de desenvolvimento;". Cf. Daniela Campos Libório Di Sarno, Elementos de Direito Urbanístico, p. 38. Cf. também Fernanda Dias Menezes de Almeida, Competências na Constituição de 1988, p. 84.

${ }^{114}$ Cf. José Afonso da Silva, Direito Urbanístico Brasileiro, p. 57-58.
} 
$\S 1^{\circ}$. A lei estabelecerá as diretrizes e bases do planejamento do desenvolvimento nacional equilibrado, o qual incorporará e compatibilizará os planos nacionais e regionais de desenvolvimento.

A propósito da atividade estatal de planejamento, Gilberto Bercovici critica essa ênfase dada pela atual Constituição à União, ignorando o papel dos Estados e Municípios na formulação dos planos. E afirma que "a preponderância da União, nessa área, não exclui a necessidade de participação de todos os entes federados na elaboração conjunta do planejamento". Não é por outra razão que o autor considera a não inclusão do planejamento no rol do artigo 23 como uma das maiores críticas a serem feitas às competências comuns definidas pela Constituição de $1988^{115}$.

Fernanda Dias Menezes de Almeida avalia essa questão de modo diverso. Para essa autora,

a crítica maior que cabe fazer à Constituição vigente não se volta tanto para a ênfase que se continuou a dar ao planejamento nacional e regional, a cargo da União.

$[\ldots]$

O que se lamenta, numa linha de democracia participativa, é que se tenha perdido a oportunidade de tornar necessária a audiência dos Estados e dos organismos regionais ou municipais interessados, quando da elaboração dos diversos planos nacionais e regionais ${ }^{116}$.

Com efeito, a ênfase dada pela Constituição de 1988 aos poderes da União em matéria de planejamento, especialmente no artigo 21 , por si só, não representa uma vedação aos Estados e Municípios de também formularem planos regionais ou locais. Tampouco constitui qualquer ofensa ao princípio federalista da autonomia das unidades federadas.

${ }^{115}$ Desigualdades regionais, Estado e Constituição, p. 155-156.

${ }^{116}$ Competências na Constituição de 1988, p. 96. A autora menciona que o anteprojeto da Comissão Afonso Arinos, em seu art. 72, XII, garantia a oitiva dos Estados e órgãos interessados quando do exercício da competência de planejamento e promoção do desenvolvimento nacional pela União. 
Trata-se tão somente de reforçar a importância de que a União, representando a unidade do Estado federal, norteie as ações públicas em determinadas áreas especialmente naquelas que demandam maior intervencionismo estatal - a fim de se buscar soluções para problemas que costumam transcender os lindes de um único Estado-membro ${ }^{117}$. A centralização relativa, portanto, é admitida pelo próprio constituinte de 1988 em situações em que ele considerou imprescindível a unidade do Estado $^{118}$.

No campo urbanístico, por exemplo, o planejamento local não se faz suficiente para resolver a problemática urbana em toda a sua complexidade. Nas palavras de José Afonso da Silva, "na medida mesma em que a idéia de urbanismo se amplia para abranger a sistematização do território, também se apresenta a exigência de que a dimensão espacial se incorpore ao planejamento no nível nacional"119.

Nesse contexto é que se inserem os dispositivos da Constituição de 1988 mencionados acima, os quais definem que, em matéria de planejamento urbano, a União estabeleça as diretrizes gerais, ou seja, as orientações mínimas a partir das quais as entidades federativas deverão desenvolver suas ações urbanísticas executivas e legislativas.

Mas se concorda, aqui, com o quanto ponderado por Fernanda Dias Menezes de Almeida, no sentido de que esses dispositivos constitucionais, ao definirem a relativa centralização de poder nas mãos da União para elaboração de planos nacionais e regionais, deveriam ter garantido a oitiva dos Estados, organismos regionais e Municípios.

\footnotetext{
${ }^{117}$ Cf. Fernanda Dias Menezes de Almeida, Competências na Constituição de 1988, p. 91.

${ }^{118}$ Vale menção o seguinte trecho de Gilberto Bercovici sobre o federalismo: "Em nenhuma concepção doutrinária o federalismo é entendido como oposto à unidade do Estado. Pelo contrário, o objetivo do federalismo é a unidade, respeitando e assimilando a pluralidade. Nem poderia ser diferente, afinal a unidade está na essência da organização estatal. Para garantir a unidade (fim), o Estado possui determinada forma de organização (meio), mais ou menos centralizada. Todo Estado, inclusive o federal, neste sentido, é unitário, pois tem como um de seus objetivos a busca da unidade. A autonomia não se opõe à unidade, mas à centralização em determinados órgãos ou setores do Estado. Neste sentido, num Estado federal a unidade é o resultado de um processo de integração, em que a autonomia não se limita a ser um objeto passivo (garantia), mas é, essencialmente, sujeito ativo na formação desta unidade estatal (participação)." (grifamos) In Desigualdades Regionais, Estado e Constituição, p. 149.

${ }^{119}$ (Grifos do autor). Direito Urbanístico Brasileiro, p. 100.
} 
A Constituição de 1988 também atribui à União, aos Estados, ao Distrito Federal e aos Municípios, competência material comum para "promover programas de construção de moradias e a melhoria das condições habitacionais e de saneamento básico"; bem como "combater as causas da pobreza e os fatores de marginalização, promovendo a integração social dos setores desfavorecidos”. (artigo 23, IX e X).

Quanto aos Estados federados, a eles são definidas competências legislativas concorrentes para complementar as normas gerais urbanísticas da União (artigo 24, I e parágrafo $\left.2^{\circ}\right)^{120}$, consideradas suas respectivas especificidades regionais, bem como “mediante lei complementar, instituir regiões metropolitanas, aglomerações urbanas e microrregiões [...] para integrar a organização, o planejamento e a execução de funções públicas de interesse comum" (artigo 25, parágrafo $\left.3^{\circ}\right)^{121}$.

Foi tímida a Constituição de 1988 ao tratar da participação dos Estados no planejamento urbano, não havendo menção específica a esta expressão como matéria de competência estadual. Mas essa sua competência é deduzida, sem maiores indagações, pelo teor do artigo 24 , inciso I e parágrafo $2^{\circ}$. Mais uma vez recorrendose às lições de José Afonso da Silva,

\begin{abstract}
Abre-se aos Estados, aí, no mínimo, a possibilidade de estabelecer normas de coordenação dos planos urbanísticos no nível de suas regiões, além de sua expressa competência para estabelecer regiões metropolitanas $^{122}$.
\end{abstract}

Até esse ponto, não se verificam dificuldades de se concluir que as competências constitucionais definidas para a União e os Estados, em matéria de preservação do patrimônio cultural são perfeitamente compatíveis com as competências que esses mesmos entes possuem em matéria urbanística.

\footnotetext{
120 “Art. 24. compete à União, aos Estados e ao Distrito Federal legislar concorrentemente sobre: I - direito [...] urbanístico. $\$ 2^{\circ}$. A competência da União para legislar sobre normas gerais não exclui a competência suplementar dos Estados”.

121 “Art. 25. [...] $\$ 3^{\circ}$. Os Estados poderão, mediante lei complementar, instituir regióes metropolitanas, aglomerações urbanas e microrregiões, constituídas por agrupamentos de Municípios limítrofes, para integrar a organização, o planejamento e a execução de funções públicas de interesse comum."

${ }^{122}$ José Afonso da Silva, Direito Urbanístico Brasileiro, p. 126.
} 
O problema se coloca quando se passa a tratar das competências constitucionais urbanísticas municipais. No inciso VIII do artigo 30 da Constituição de 1988, vem estabelecida a competência material privativa do Município de "promover, no que couber, adequado ordenamento territorial, mediante planejamento e controle do uso, do parcelamento e da ocupação do solo urbano".

José Afonso da Silva vê nesse dispositivo o fundamento do planejamento urbanístico local. E reforça que

Isso não é competência suplementar, não. É competência própria, exclusiva, que não comporta interferência nem da União, nem do Estado. [...] Esse ordenamento [territorial] é função do plano diretor, aprovado pela Câmara Municipal, que a Constituição elevou à condição de instrumento básico da política de desenvolvimento e de expansão urbana ${ }^{123}$

A partir desse dispositivo referido acima, Ulpiano Bezerra de Meneses avalia que as normas e critérios de zoneamento (tais como de densidade populacional, de volume de edificações e de uso) constituiriam matéria típica de competência dos Municípios e que isso representaria um impasse, por exemplo, aos órgãos estaduais de preservação de deliberarem acerca de destinação de usos de bens imóveis tombados. Para o autor,

o uso de bens culturais constitui uma das principais justificativas da proteção que o poder público (nos três níveis) é obrigado a fomentar.

\footnotetext{
${ }^{123}$ Direito Urbanístico Brasileiro, p. 58. As competências privativas e expressas estariam teoricamente livres de qualquer interferência material dos outros entes federados. Hely Lopes Meirelles refere-se a quatro regras facilitadoras da distinção das três órbitas de ação governamental, esquematizadas e enumeradas por Victor Nunes Leal. A primeira dessas regras é a de que a competência municipal expressa e exclusiva afasta qualquer outra competência sobre o assunto, seja ela federal ou estadual. "A manifestação expressa e privativa da competência do Município repele a de qualquer outra entidade estatal, poder, órgão ou autarquia. Qualquer ingerência estranha na competência municipal será inconstitucional e afastável por via judicial”. In Direito Municipal Brasileiro, p. 129-130.
} 
O uso e a efetividade das funções em benefício da coletividade é mesmo o que legitima, em última instância, a própria preservação ${ }^{124}$.

Primeiramente, ocorre destacar o quanto já ponderado por Celso Ribeiro Bastos acerca das competências municipais explicitadas no artigo 30 da Constituição. $\mathrm{Na}$ lição desse autor, essas competências "não devem estimular uma visão exageradamente grandiosa da autonomia municipal”, já que muitas delas sofrem restrição de uma normatividade superior. ${ }^{125}$

Nessa mesma linha, destaque-se a competência material referida no artigo 182 da Constituição - para execução da Política de Desenvolvimento Urbano -, a qual não obstante seja privativa do Poder Público municipal, deverá ser realizada "conforme as diretrizes gerais fixadas em lei"126.

Em segundo lugar, se por um lado José Afonso da Silva identifica no dispositivo constitucional acima a competência exclusiva do município, por outro lado ele próprio reconhece que em determinados setores urbanísticos a competência para atuar é comum à União, Estados, Distrito Federal e Municípios e para legislar é concorrente entre estes entes, não privativa do Município. E chega até mesmo a apontar como exemplos desses setores específicos a proteção de obras de valor histórico, artístico e cultural e dos monumentos, paisagens notáveis e sítios arqueológicos, assim como a proteção do meio ambiente e o combate à poluição:

Aqui, sim, a posição dos Municípios é diversa daquela apontada acima em relação às normas urbanísticas em geral, porque nesses setores a atuação legislativa municipal é suplementar da legislação federal e estadual, com aplicação do disposto no art. 30, II, e especialmente ao teor específico do inciso IX desse artigo, que declara caber ao Município promover a proteção do patrimônio

\footnotetext{
124 "A cidade como bem cultural", In Victor Hugo Mori et alli (orgs.), Patrimônio: Atualizando o debate, p. 41.

${ }^{125}$ Curso de Direito Constitucional, p. 278. Nesse mesmo sentido, Fernanda Dias Menezes de Almeida, op. cit., p. 118.

126 “Art. 182. A Política de Desenvolvimento Urbano, executada pelo Poder Público municipal, conforme diretrizes gerais fixadas em lei, tem por objetivo ordenar o pleno desenvolvimento das funções sociais da cidade e garantir o bem-estar de seus habitantes". Trata-se da Lei federal n ${ }^{\circ}$ 10.257/01 (Estatuto da Cidade).
} 
histórico-cultural local, observada a legislação $e$ a ação fiscalizadora federal e estadual. ${ }^{127}$

A expressão "no que couber", empregada pelo constituinte no artigo 30, VIII, reforça essa noção de que existem limites à exclusividade conferida ao Município para o planejamento territorial.

Portanto, não se vislumbram óbices constitucionais, baseados nas competências urbanísticas municipais, para a definição de usos de bens culturais pelos órgãos de preservação estaduais, ou mesmo pelo órgão federal, desde que estas ações estejam inseridas no escopo de cooperação entre os entes, dada a competência comum na matéria.

Apenas há de se advertir que essa definição de uso para bens culturais pelo Poder Público - seja pelo órgão federal, seja pelo estadual ou municipal de preservação -, caso incida sobre propriedades privadas e de forma individualizada, ensejará o direito do particular à justa indenização, em razão do esvaziamento total ou parcial do conteúdo econômico da propriedade causado pelo ato do Poder Público $\left(\operatorname{artigo} 5^{\circ} \text {, inciso XXII da Constituição Federal }\right)^{128}$.

De tudo quanto exposto neste item, conclui-se que os impasses a uma política de preservação do patrimônio cultural integrada ao direito urbanístico não residem no âmbito constitucional. Conforme demonstrado, a Constituição de 1988 previu competências bastantes a todos os níveis de poder para o concurso e a integração de

\footnotetext{
127 (Grifos do autor). Direito Urbanístico Brasileiro, p. 65-66.

${ }^{128}$ Trata-se de situação em que destacadas do domínio as prerrogativas de usar e fruir o bem, em razão de ato posterior do poder público. A propósito de critérios para distinção entre situações que gerariam o dever do Estado de indenizar e as que apenas conformariam o conteúdo do direito de propriedade, cf. Carlos Ari Sundfeld, Direito Administrativo Ordenador, p. 89-104; Cf. também José Canasi, Tratado teorico practico de la expropriación pública, p. 65 e ss; e ainda, cf. Ernst Forsthoff, Tratado de Derecho Administrativo, p. 426 e ss. Para Lucia Valle Figueiredo, "se a propriedade privada tiver sua possibilidade de utilização diminuída, estará o Poder Público, ao tombar, constituindo uma servidão e, assim, deverá indenizar o proprietário na proporção em que este for atingido pela medida do tombamento, portanto, na proporção do dano". In Disciplina Urbanística da Propriedade, p. 63. A jurisprudência do Superior Tribunal de Justiça já assentou entendimento de que a restrição administrativa sobre o uso da propriedade que causar o esvaziamento do seu conteúdo econômico gera ao proprietário o direito à indenização. Como casos em que apontado esse entendimento pacífico, cf. Recurso Especial 188781/PR, j. 20.09.1999; Recurso Especial 52905/SP, j. 13.12.1994; Recurso Especial 34006/SP, j. 25.10.1993; Recurso Especial 401.264/SP, j. 05.09.2002; Recurso Especial 435128/SP, j. 11.02.2003; Recurso Especial 665791/SP, j. 05.04.2005; dentre outros. Cf. no Capítulo 4 deste trabalho comentários acerca do tombamento de uso.
} 
suas ações legislativas e executivas tanto em matéria de proteção do patrimônio cultural, como no tocante ao desenvolvimento urbano (reabilitação e planejamento urbanos associados à inclusão social).

O que parece faltar exatamente é vontade política de integração dos órgãos públicos de ordenação urbana e de preservação, nos três níveis da Federação, bem como de implementação de planos nacionais, regionais e locais que coordenem as ações dos entes federados, considerada a atual realidade urbana e as novas e mais ampliadas definições de patrimônio cultural. ${ }^{129}$

\subsection{Ação dos três Poderes}

O parágrafo $1^{\circ}$ do artigo 216 da Constituição Federal de 1988, ao estabelecer que "o Poder Público, com a colaboração da comunidade, promoverá e protegerá o patrimônio cultural brasileiro por meio de inventários, registros, vigilância, tombamento e desapropriação, e de outras formas de acautelamento e preservação", dá a tônica da política nacional de preservação do patrimônio cultural brasileiro, vinculando todos os Poderes Públicos - da União, dos Estados e dos Municípios - à consecução desse objetivo. Aponta, assim, para fins futuros, servindo de pauta de valores para as ações do Poder Público. ${ }^{130}$

\footnotetext{
${ }^{129}$ Cf. Paulo Ormindo de Azevedo, "Comentário 4: A cidade como obra aberta", In Patrimônio: Atualizando o debate, p. 67.

${ }^{130}$ José Afonso da Silva, Aplicabilidade das Normas Constitucionais, p. 149. Ernest Benda, num contexto em que discutia a cláusula do Estado social na Lei Fundamental Alemã, considerou-a como 'categoria jurídica voltada ao futuro': "O fato de que só em pequena medida caiba inferir diretamente respostas materiais é um inconveniente apenas em uma primeira e elementar aproximação. O mandamento constitucional continua existindo. Não cabe à discrição da maioria parlamentar executá-lo ou não. Mas o detalhe do que deva ser feito não está tão predeterminado que não exista margem para a busca da melhor alternativa”. apud Maria Paula Dallari Bucci, "O conceito de política pública em Direito", In Maria Paula Dallari Bucci (org.), Políticas Públicas: Reflexões sobre o conceito jurídico, p. 9. Também Maria Paula Dallari Bucci, ao tratar da positivação constitucional das normas sociais, ressalta que "[...] seria absolutamente frustrante, do ponto de vista político, aceitar a inexequibilidade dos direitos sociais. Do ponto de vista jurídico, isso representaria tornar inócuo o qualificativo de 'Estado social de direito' afirmado no art. $1^{\circ}$ da Constituição. Partindo da conhecida máxima de interpretação de que a lei não contém palavras inúteis, não se pode tomar tal locução como sinônimo de 'Estado de Direito', omitindo a carga finalística do adjetivo 'social' num Estado em que as
} 
José Afonso da Silva considera haver nesse dispositivo uma

peremptoriedade da norma, que a faz in fieri para a eficácia plena, a ponto de poder-se duscutir se, apesar de um certo sentido de programa a realizar, não se acham, aí, traduzidos, se não direitos subjetivos, ao menos interesses legítimos que implicam, no mínimo, obrigações administrativas de aparelhar-se para executar a norma. ${ }^{131}$

Essa ideia é reforçada pela enumeração, no dispositivo, das providências que deverão ser tomadas para aplicação da norma constitucional (realização de inventários, registros, tombamentos, etc).

No tocante às cidades, o constituinte de 1988 também programou especialmente aos Municípios a implementação de políticas de desenvolvimento urbano para os seus respectivos territórios, com vistas a ordenar o pleno desenvolvimento das funções sociais da cidade e garantir o bem-estar dos seus habitantes (artigo 182, caput). Definiu que essas políticas a cargo dos Poderes Públicos Municipais deveriam seguir diretrizes gerais fixadas em lei ${ }^{132}$, assim como ser baseadas em um Plano Diretor ${ }^{133}$ - que deverá revestir-se da forma de lei municipal e conter as exigências fundamentais de ordenação da cidade, necessárias ao delineamento da função social da propriedade urbana (artigo $182, \S 1^{\circ}$ e $2^{\circ}$ ).

tarefas sociais ainda estão por ser feitas". In "O conceito de política pública em Direito". In Maria Paula Dallari Bucci (org.), Políticas Públicas: Reflexões sobre o conceito jurídico, p. 10.

131 Op. Cit., p. 149. Acerca das normas constitucionais definidoras de direitos sociais específicos, José Joaquim Gomes Canotilho adverte que "as diretivas por elas definidas, longe de serem meros convites para legislar, assumem o caráter de verdadeiras imposições constitucionais de atividade legiferante". In Direito Constitucional, p. 178. A respeito da incidência do princípio da aplicabilidade direta das normas constitucionais de meio ambiente (dispensando-se intervenção de lei mediadora), cf. José Joaquim Gomes Canotilho, Protecção do Ambiente e Direito de Propriedade: Crítica de Jurisprudência Ambiental, p. 18.

${ }^{132}$ Hoje expressas na Lei Federal no 10.257/01 (Estatuto da Cidade). Neste documento, também se reconhece a necessidade dessa política municipal de desenvolvimento urbano seguir as regras gerais estabelecidas pelos planos nacionais, regionais e estaduais de ordenação do território e de desenvolvimento econômico e social, assim como as definidas no planejamento das regiões metropolitanas, aglomerações urbanas e microrregiões (art. $4^{\circ}$, I e II da Lei federal 10.257/01).

${ }^{133}$ O Plano Diretor é obrigatório somente para as cidades com mais de vinte mil habitantes (art. $182, \S 1^{\circ}$ da Lei 10.257/01). 
Todas as normas constitucionais acima referidas apontam, portanto, para uma série de medidas a serem adotadas pelos Poderes Legislativo e Executivo para realização dos fins que mencionam.

Diante desse dever do Estado de adoção de medidas voltadas a esses fins, propõe-se, neste item, verificar o modo como hoje é sistematizado o tema da preservação do patrimônio cultural urbano pelos Poderes Legislativo e Executivo. No que se refere ao Poder Judiciário, serão verificados alguns meios processuais de tutela do patrimônio cultural urbano. Será dada ênfase às atividades legislativas e executivas no nível nacional.

\subsubsection{O Decreto-lei $n^{0} 25 / 37$ enquanto lei geral de preservação do patrimônio cultural}

O tema da preservação do patrimônio cultural recebeu tratamento legal inédito no Brasil três anos depois que versada a matéria pela primeira vez no plano constitucional, pela Constituição de 1934. Assim, em 30 de novembro de 1937, foi publicado pela União o Decreto-Lei no $25^{134}$ visando a "organizar a proteção do patrimônio histórico e artístico nacional".

Seu texto incorporava as contribuições sucessivamente acumuladas das diversas propostas legislativas anteriores ${ }^{135}$, definindo juridicamente o "patrimônio histórico e artístico nacional" (Capítulo I), bem como instituindo o regime jurídico próprio do instrumento que se tornaria - e assim se mantém, até os dias de hoje - o

\footnotetext{
${ }^{134}$ O Decreto-lei 25/37 decorre de um projeto de lei de 1936, de autoria do jurista Rodrigo Melo Franco de Andrade, que então já assumia a diretoria do recém criado SPHAN.

${ }^{135}$ A ideia de criação de uma lei nacional de proteção do patrimônio cultural vinha sendo debatida na Câmara dos Deputados desde 1923, quando o deputado pernambucano Luiz Cedro apresentou pela primeira vez à Casa um projeto de lei dispondo sobre a matéria. Este projeto de lei, assim como outros dois apresentados posteriormente por Augusto de Lima (1924) e José Wanderley de Araújo Pinho (1930), não obstante tenham sido abandonados alegadamente por razões de inconstitucionalidade - a Constuição de 1891 assegurava o direito de propriedade "em toda a sua plenitude" -, contém normas que muito se assemelham às constantes do Decreto-Lei n ${ }^{\circ}$ 25/37. Para o inteiro teor dessas propostas, cf. Fundação Nacional Pro-Memória, Proteção e revitalização do patrimônio cultural no Brasil: Uma tragetória, Anexos II a IV, p. 63-88.
} 
mecanismo de tutela do patrimônio cultural mais recorrente nas práticas dos órgãos preservacionistas, qual seja, o tombamento (Capítulos II a V).

Atualmente, não obstante a relativa incompatibilidade de suas normas gerais introdutórias com a ordem constitucional de 1988 - tais como as normas de definição jurídica do patrimônio histórico e artístico nacional (caput do artigo $1^{\circ}$ ) e de condicionamento do reconhecimento oficial do bem como patrimônio cultural à sua inscrição em um dos Livros do Tombo (parágrafo $1^{\circ}$ do artigo 1) -, o Decreto-lei $n^{\circ}$ 25/37 permanece em plena vigência, preservando o título de "Lei Nacional de Proteção do Patrimônio Cultural".

Iniciando-se a presente abordagem com a análise desse documento legal em sua estrutura, observa-se que nele não existe uma distinção clara entre normas gerais e normas especiais, o que é de praxe verificar-se em leis expedidas pela União.

Algumas de suas disposições podem ser mais facilmente reconhecidas como normas gerais, como as que tratam dos efeitos do tombamento - em especial a que veda a destruição, demolição ou mutilação de bens tombados e a que veda construções ou fixação de anúncio de cartazes na vizinhança de bens tombados sem prévia autorização (artigos 17 e 18, respectivamente), posto que são as obrigações que melhor caracterizam o referido instituto.

Outras também, excepcionalmente, revelam-se com alguma clareza como normas especialmente dirigidas à Administração Pública da União, tais como aquelas referentes a prazos e procedimentos aplicáveis ao processo de tombamento conduzido pelo órgão de preservação federal então recém criado - o SPHAN (artigo $9^{\circ}$ ).

Mas não há no Decreto-lei 25/37 qualquer sistematização - mediante o tratamento das normas gerais e especiais em capítulos apartados, por exemplo - no sentido de "organizar [efetivamente] a proteção do patrimônio histórico e artístico nacional". 136

Tampouco é possível identificar no Capítulo V desse Decreto-lei, intitulado "Disposições Gerais", um agrupamento das normas gerais atinentes ao tema, pois

\footnotetext{
${ }^{136}$ Essa é a expressão que intitula o Decreto-lei no $25 / 37$.
} 
como se verifica da leitura dos seus dispositivos (artigos 23 a 30), há normas ali inseridas que são nitidamente dirigidas à Administração Pública federal - como o artigo 25, que incumbe o SPHAN de procurar entendimentos com autoridades eclesiásticas e instituições científicas, dentre outras pessoas, com vistas à cooperação mútua em benefício do patrimônio -, assim como há normas fora desse Capítulo manifestamente gerais, conforme apontado acima.

No entanto, maiores discussões sobre essa distinção precisa entre normas gerais e normas especiais do Decreto-lei $n^{0}$ 25/37 não faziam muito sentido até a década de 1960, uma vez que nesse período, o Poder Público da União, por meio do SPHAN, centralizava praticamente todas as ações estatais preservacionistas do então "patrimônio histórico e artístico nacional".

Isso muito embora a Constituição de 1934 já atribuísse competência conjunta à União, aos Estados e aos Municípios em matéria de proteção ao patrimônio cultural ${ }^{137}$ e o próprio Decreto-lei $n^{\circ} 25 / 37$ reconhecesse a pertinência da atuação executiva e legislativa dos Estados federados ao prever, no artigo 23, que o Poder Executivo federal deveria providenciar acordos com estes entes visando à "coordenação e [ao] desenvolvimento das atividades relativas à proteção do patrimônio histórico e artístico nacional” e à "uniformização da legislação estadual complementar". 138 e 139

Essa situação começou a mudar na década de 1960, como dito, quando aumentaram as produções legislativas estaduais em matéria de preservação do patrimônio cultural. No plano municipal, essas produções tornaram-se mais expressivas na década de 1980.

De modo que, presentemente, dada a coexistência de leis federal, estaduais e municipais versando sobre essa mesma matéria, distinções mais precisas,

\footnotetext{
${ }^{137}$ Cf. Item 3.2 deste trabalho.

138 “Art. 23. O Poder Executivo providenciará a realização de acordos entre a União e os Estados, para melhor coordenação e desenvolvimento das atividades relativas à proteção do patrimônio histórico e artístico nacional e para a uniformização da legislação estadual complementar sobre o mesmo assunto".

${ }^{139}$ Esta última atribuição legal do Poder Executivo federal de agenciar a "uniformização da legislação estadual complementar" evidencia, no entanto, relativa centralização nas mãos da União do poder dos Estados de legislar, na medida em que as normas estaduais complementares deveriam, em tese, refletir os interesses regionais de cada estado, consideradas as características que os diferenciam entre si.
} 
especialmente na legislação federal, entre normas gerais e normas especiais de preservação do patrimônio cultural revelam-se essenciais para se conhecer, com maior segurança e clareza, os exatos campos das atuações legislativas complemetares estadual e municipal na matéria.

Feitas essas considerações de estrutura, parte-se para a análise do conteúdo do Decreto-lei $n^{\circ} 25 / 37$, no que se refere à sua compatibilidade com as diversas demandas de preservação surgidas ao longo dos anos.

Esse documento legislativo, ao conceber juridicamente o patrimônio como um universo composto exclusivamente por bens materiais, acabou traçando limites bastante restritos ao campo de incidência de tutela jurídica. Como explica Maria Cecília Londres Fonseca,

\begin{abstract}
A preocupação, nesse caso, não era com o aspecto conceitual ou com o organizacional, [...] mas com recursos operacionais que fossem não só legais como também reconhecidos como legítimos. [...] para viabilizar a proteção legal era necessário referir-se a coisas ("bens móveis e imóveis"), o que marcava a inadequação do instrumento proposto - o tombamento - para proteger manifestações folclóricas, como lendas, superstições, danças, dramáticas, etc. ${ }^{140}$
\end{abstract}

Não obstante os bens imateriais já tivessem sido cogitados como objeto de preservação em um anteprojeto de lei elaborado anteriormente por Mario de Andrade, eles foram excluídos do regime de proteção patrimonial instituído pelo Decreto-lei $\mathrm{n}^{\circ}$ 25/37, voltando-se este particularmente aos monumentos e obras de excepcional valor histórico ou artístico nacional. Esse objeto mais restrito atendia a contento, naquele início, aos anseios preservacionistas do então recém criado SPHAN.

De acordo com o relato de Paulo Ormindo de Azevedo, nos primeiros vinte anos de vigência do Decreto-lei $n^{\circ}$ 25/37, este funcionou "como um instrumento de

\footnotetext{
${ }^{140}$ O patrimônio em processo: trajetória da política federal de preservação no Brasil, p. 104-105. A autora, nessa passagem, confronta o Decreto-Lei n $25 / 37$ com o anteprojeto de lei formulado pouco tempo antes por Mario de Andrade, para os mesmos fins, a pedido do então ministro Gustavo Capanema. Este anteprojeto foi ao final preterido pelo daquele, mas adotava uma concepção muito mais ampla de patrimônio reconhecidamente avançada para seu tempo - que contemplava as culturas erudita e popular, material e imaterial.
} 
preservação passivo, impedindo demolições e adulterações volumétricas de setores urbanos, mas não propriamente como um instrumento de conservação" ${ }^{141}$. Isso porque o referido Decreto-lei não cuidava de outros mecanismos de preservação senão do tombamento, que tem por finalidade precípua a garantia da imodificabilidade da coisa protegida.

Mesmo que essa lei demonstrasse, já nesse tempo, algumas deficiências, na prática, para garantir algo mais do que a preservação passiva de bens materiais culturais, o País, nessa época, era predominantemente rural, de modo que esse patrimônio ainda não se via ameaçado senão pelo abandono e pelo desgaste do tempo $^{142}$.

Algumas distorções no emprego desse documento legislativo começaram a surgir ainda na década de 1940, quando verificada a aplicação do regime do tombamento para a proteção de áreas urbanas ${ }^{143}$. Mais tarde, mesmo municípios inteiros, como Porto Seguro (tombado pelo IPHAN em 1968), foram submetidos a esse mesmo instrumento.

Mas a defasagem do Decreto-lei $n^{\circ}$ 25/37 para "organizar a proteção do patrimônio histórico e artístico nacional" - portanto, para figurar como a lei geral de preservação do patrimônio cultural brasileiro ${ }^{144}$-, manifestou-se com maior ênfase a partir da década de 60, quando o acelerado processo de urbanização trouxe novos desafios para o tema e veio confirmar, assim, a insuficiência do tombamento como instrumento único de preservação ${ }^{145}$. A esse respeito, analisa Paulo Ormindo de Azevedo:

\footnotetext{
${ }^{141}$ Op. Cit., p. 67. O autor relata ainda, quanto aos desdobramentos da aplicação dessa lei nesse período, que "sob sua vigência muitas famílias abandonaram os centros históricos e foram substituídas por comerciantes informais e migrantes do campo. Muitos donos abandonaram seus imóveis para resgatarem o solo para estacionamentos". Cf. também Jean Benoit Bleyon, L'urbanisme el la protección des sites..., p. 169.

${ }^{142}$ Cf. Nestor Goulart Reis Filho, "Por uma nova política de preservação", In OESP, 9 de janeiro de 2009, p. A2.

${ }^{143}$ Idem, ibidem, p. 67. A análise da aplicação do tombamento para proteção de áreas e setores urbanos é aprofundada mais adiante neste trabalho, no item 4.2, no qual se discorrerá acerca do tombamento de bairros.

${ }^{144}$ Ainda que se reconheça que a referida lei preserva sua pertinêcia para cuidar de bens isolados, aplicandose o regime do tombamento nela detalhado.

${ }^{145}$ Cf. Paulo Ormindo de Azevedo, "Cometário 4: A cidade como obra aberta", In Victor Hugo Mori et alli (orgs.), Patrimônio: Atualizando o debate, p. 67.
} 
Quando, porém, na década de 60 a pressão migratória e o crescimento vegetativo ameaçavam explodir as nossas cidades, ficou patente que aquele instrumento legal, criado para preservar monumentos e imagens sacras, não dava conta das complexas transformações sócio-econômicas e da deterioração física de nossos centros históricos. ${ }^{146}$

É também desse tempo a Lei federal $n^{\circ} 3.924 / 61$, que tratou especificamente da guarda e da proteção dos “monumentos arqueológicos e pré-históricos”, tendo instituído, para tanto, um regime especial de limitação ao exercício do direito de propriedade diferente do tombamento em muitos aspectos, a começar pelo caráter geral e abstrato dessa limitação, decorrente da própria lei.

Este regime especial tratou de estabelecer de modo explícito que a propriedade de superfície, regida pelo direito comum, não incluiria a das jazidas arqueológicas ou pré-históricas e que estas, para todos os efeitos e especialmente para os de exploração e aproveitamento econômico, seriam consideradas bens patrimoniais da União a partir da vigência da lei (artigo $1^{\circ}$, parágrafo único e artigo $\left.7^{\circ}\right)^{147}$. Admitiu também a ocupação temporária de terrenos de propriedade particular para fins de pesquisa em jazidas arqueológicas por instituições científicas.

Enfim, por meio dessa Lei, reconheceu-se que para a fruição verdadeira desse tipo de bem pela sociedade, era preciso um regime que oferecesse mais do que a simples e passiva imodificabilidade de uma área detentora de reminiscências arqueológicas e pré-históricas $^{148}$. Era preciso que ele garantisse também livre acesso e exploração dessa área para pesquisas, escavações, análise do solo e retirada de

\footnotetext{
${ }^{146}$ Idem, Ibidem, p. 67.

${ }^{147}$ É que a Constituição de 1946, então vigente, não tratava expressamente desses bens arqueológicos e préhistóricos, tampouco os definia como bens da União. O legislador tratou, então, de reconhecer o direito dos proprietários sobre as jazidas já em exploração na data de publicação da lei, sob a condição de que esse fato fosse comunicado à Diretoria do Patrimônio Histórico Nacional e que não se destruíssem, nem mutilassem os bens culturais ali encontrados. Essa pouca clareza é resolvida atualmente pelo teor dos artigos 20, X e 176 da Constituição de 1988, que reconhecem as jazidas, cavidades naturais subterrâneas e os sítios arqueológicos e pré-históricos como pertencentes à União.

${ }^{148} \mathrm{O}$ que já era garantido pelo regime do tombamento. ("Art. $1^{\text {o }}$. Constitui o patrimônio histórico e artístico nacional o conjunto dos bens móveis ou imóveis existentes no país e cuja conservação seja de interesse público, [...] por seu excepcional valor arqueológico [...]”).
} 
fragmentos do local, de modo a permitir uma posterior recomposição das peças, estudos sobre estas, sua identificação, inventariação e difusão dos dados coletados.

Outra disposição normativa envolvendo a matéria de preservação de bens culturais foi instituída em 2000, mas não pelo Poder Legislativo federal, e sim pelo Presidente da República, mediante o Decreto ${ }^{\circ}$ 3.551, de 4 de agosto de 2000. Este Decreto dispõe sobre o mecanismo de registro de bens culturais de natureza imaterial e "cria o Programa Nacional do Patrimônio Imaterial""149, contemplando, assim, aquela parcela imaterial do patrimônio cultural não compreendida na definição, tampouco no modo de tutela previstos no Decreto-lei $n^{\circ} 25 / 37$, mas presente e extremamente importante no ambiente urbano. E declara o dever do Ministério da Cultura de garantir a ampla divulgação e promoção desse patrimônio imaterial.

O Estatuto da Cidade, por sua vez, apresentou em 2001 uma relação de instrumentos urbanísticos passíveis de contribuir para o cuidar do patrimônio no ambiente urbano, sem, todavia, oferecer maiores sistematizações a esta matéria. E nem seria esta Lei a mais adequada para tanto, posto que ela cuida especificamente de oferecer aos Municípios as diretrizes gerais de suas políticas de desenvolvimento urbano, que deverão abranger uma série de aspectos, sendo a preservação do patrimônio cultural apenas um deles ${ }^{150}$.

Assim, esta Lei tão somente sugere aos Municípios a utilização de mecanismos para os fins de preservação, como o tombamento, o Estudo de Impacto de Vizinhança, a transferência do direito de construir, a desapropriação. Deixa transparecer, é verdade, a necessidade de que a preservação do patrimônio cultural urbano seja vista no contexto da ordenação urbana e o fato de que os Municípios, nesse aspecto, muito têm a contribuir. Mas, como dito, não é nessa Lei que se encontra - nem que se deve esperar encontrar - a sistematização geral da matéria.

\footnotetext{
${ }^{149}$ Eis a expressão contida no enunciado do Decreto, não obstante não sejam fornecidos em seu texto quaisquer detalhamentos sobre os recursos a serem empregados para implementação dessa suposta política, as metas a serem alcançadas, os prazos estimados e os resultados esperados desse Programa, etc, postergando-se para uma futura oportunidade o cumprimento, pelo Estado, dos deveres sociais a ele dirigidos nas normas constitucionais programáticas competentes.

${ }^{150}$ Tanto que, com relação aos instrumentos de política urbana que menciona, estabelece, no artigo $4^{\circ}, \S 1^{\circ}$, que eles: "regem-se pela legislação que lhe é própria, observado o disposto nesta Lei”.
} 
De modo que hoje, passados mais de 40 anos de enfrentamento das intensas transformações sócio-econômicas no cenário urbano, considerado o reconhecimento de uma concepção ampliada de patrimônio cultural pela Constituição de 1988, por influência dos debates e formulações desenvolvidos sobre o tema no plano internacional, e tendo em vista as diretrizes gerais estabelecidas para a gestão das cidades, conclui-se não ser mais possível considerar o Decreto-lei no 25/37 como a lei geral de proteção do patrimônio cultural.

De efeito, o Decreto-lei no $25 / 37$ preserva em muito sua importância no que se refere à garantia de imodificabilidade de bens imóveis e mesmo à tutela dos bens culturais móveis, mas não sistematiza, nem compreende toda a matéria. Não indica princípios aplicáveis, não define adequadamente o amplo objeto de tutela do patrimônio cultural brasileiro, não enumera os meios garantidores da sua promoção e proteção, tampouco aponta os mecanismos adequados à garantia de tutela para cada tipo diferente de bem patrimonial.

É verdade que, como visto, o Direito positivo prevê, de modo esparso, uma concepção ampla para o patrimônio cultural, assim como alguns regimes especiais para tutela dos bens neste compreendidos. Mas a codificação da matéria num único texto legislativo federal traz como contribuição uma maior clareza da unidade do sistema. Nesse aspecto, o direito do meio ambiente natural é mais avançado, posto que desde a década de 1980 conta com a vigência da Lei nº 6.938/81.

A título de exemplo de codificação da matéria em outros países, cite-se o caso recente da Itália, que por meio do Decreto legislativo de 22 de janeiro de 2004, n. 42, publicou o Codice dei beni culturali e del paesaggio, que contém em si os princípios gerais de tutela, fruição e valorização dos bens culturais; da definição de patrimônio cultural; das funções e competências do Estado italiano, das regiões e outras entidades públicas territoriais, em matéria de tutela e valorização do patrimônio cultural; dos modos pontuais de tutela (vigilância, inspeção, proteção e conservação); do controle da circulação dos bens culturais móveis; da tutela e gestão dos bens paisagísticos; e mesmo das sanções administrativas e penais. 
Por fim, no nível dos Estados, as produções legislativas de caráter geral limitam-se a transcrever o teor do Decreto-Lei $n^{\circ}$ 25/37, na maioria dos casos, sem maiores preocupações em adequar a matéria a especificidades regionais. No âmbito municipal, de um modo geral, mesma observação é feita com relação às leis especiais preservação editadas por estes entes.

\subsubsection{Atuação do Poder Executivo}

Num primeiro momento de atuação do então SPHAN, quando predominava forte centralização na política de preservação adotada, algumas áreas urbanas foram declaradas oficialmente como patrimônio histórico e artístico nacional. Mas nesse tempo, essas áreas eram concebidas, elas próprias, como verdadeiros monumentos, ou seja, cada uma delas sendo uma obra de arte pronta e acabada.

As ações de preservação que incidiam sobre essas áreas urbanas voltavam-se, então, basicamente à conservação intacta ou ao restabelecimento de uma integridade estética das edificações nela contidas. Valorizavam-se as expressões do barroco colonial, por se entender esse estilo como representativo da arte genuinamente brasileira. E em razão disso, era recorrente a restauração das edificações históricas a um estado colonial, eliminando-se, por exemplo, todos os elementos ecléticos eventualmente encontrados nestas.

Foi com esse propósito, de conservação de áreas urbanas como verdadeiros monumentos, que foram tombadas, já no início das ações do SPHAN, as cidades históricas mineiras de Ouro Preto, Mariana, Tiradentes, São João del Rei e Diamantina, todas elas expressões do barroco e, portanto, tidas como exemplares excepcionais de um estilo artístico verdadeiramente nacional.

Mas o crescimento acelerado das cidades, desencadeado pelo processo de industrialização do País a partir dos anos 50, associado ao caráter marcadamente cultural da atuação do SPHAN, que confrontava com o novo modelo de 
desenvolvimento brasileiro, geraram necessidades de redimensionamento da política de preservação do SPHAN. ${ }^{151}$

Sem contar a falta de recursos financeiros e administrativos, com que tinha de lidar este Serviço para gestão de um patrimônio que crescia a passos largos, conforme observado por Nestor Goulart Reis Filho:

O patrimônio artístico e histórico tem sido considerado, no Brasil, como um acervo cultural que o poder público se empenha em preservar, às suas custas, através de algumas amostras de significação excepcional, que são guardadas como documentos da vida cultural de outras épocas. [...] De acordo com esse processo [de tombamento], nos vários Estados da federação selecionam-se algumas obras, consideradas notáveis por seu significado artístico ou histórico, sobre as quais se estende a proteção oficial e em sua restauração e conservação despendem-se os recursos disponíveis.

Dessa política, aplicada de forma criteriosa, resultou o prestígio indiscutível de que goza a repartição correspondente, a Diretoria do Patrimônio Histórico e Artístico Nacional, que há mais de trinta anos vem conseguindo, com um trabalho de alto nível técnico, preservar as manifestações culturais mais importantes do País. Todavia, a extensão de seus resultados vem sendo limitada, sensivelmente, pela carência de meios financeiros. Como, na prática, os ônus das medidas defensivas recaem sempre sobre os cofres públicos, o custo relativamente elevado dessa aplicação termina por restringir as possibilidades de ação da repartição federal que tende a concentrar os seus esforços em áreas como Bahia, Pernambuco e Minas Gerais, onde o volume de suas responsabilidades se destaca em relação a outras regiões do País.

\footnotetext{
${ }^{151}$ Conforme aponta Maria Cecília Londres Fonseca: "Nas décadas de 1950 e 1960 ocorreram grandes mudanças no modelo de desenvolvimento brasileiro, responsáveis pelos impasses com que a política de preservação do Sphan foi confrontada, levando a instituição e outros setores da administração pública que passaram a se interessar pela questão, a recorrer a novas alternativas de atuação. Nesse período a ideologia do desenvolvimentismo atrelou o nacionalismo aos valores da modernização. Foi a época áurea da industrialização, da urbanização e da interiorização, estimuladas pela construção de Brasília. As conseqüências para a preservação desse modelo de desenvolvimento repercutiram não apenas no nível simbólico - na medida em que essa ideologia se contrapunha à continuidade e à tradição - como nos níveis econômico e social - devido ao intenso processo de migração para as capitais e a valorização do solo urbano, desarticulando os processos espontâneos de preservação do patrimônio, tanto o edificado quanto o paisagístico. Na prática do Sphan, surgiram tensões agudas, especialmente na preservação das cidades históricas e dos centros históricos das grandes cidades." O patrimônio em processo..., p. 141.
} 
Como consequência, um número muito grande de edifícios e obras artísticas em geral, de grande importância regional mas de valor relativo no plano nacional, é condenado ao abandono, à destruição ou à descaracterização. Mesmo manifestações culturais de interesse nacional, como as que se referem à história do café e à origem da industrialização no Brasil - ambas ocorrendo em boa parte no Estado de São Paulo - estão desaparecendo rapidamente, pois as ocorrências dos séculos coloniais tendem a ser mais valorizadas do que aquelas. ${ }^{152}$

Diante dessa realidade, uma nova diretriz para a política de preservação passou a ser assumida mais explicitamente na década de 1970, baseada na descentralização das atividades protecionistas para os âmbitos dos Estados e dos Municípios.

O Compromisso de Brasília (de abril de 1970), assim como o Compromisso de Salvador (de outubro de 1971) elucidaram claramente essa tendência naquela época. Eles consistem em documentos compiladores de proposições adotadas por Governadores de Estado, Secretários Estaduais de Cultura, Prefeitos de Municípios interessados e representantes de Instituições Culturais, a partir de discussões havidas entre eles em dois encontros promovidos pelo Governo federal. Nesses documentos estão contidas recomendações aos Estados e Municípios de adoção de uma série de medidas que prometiam viabilizar a então declarada necessária ação supletiva destes entes na proteção de bens culturais de valor nacional, bem como permitir que os Estados assumissem a proteção de bens de valor regional, sob a orientação técnica do então Departamento do Patrimônio Histórico e Artístico Nacional - Dphan.

Nesse tempo, diversos órgãos estaduais de preservação do patrimônio cultural encontravam-se em recente atividade. E órgãos municipais de preservação também não tardaram em surgir e atingir quantidade expressiva ${ }^{153}$.

\footnotetext{
152 (Grifamos). Nestor Goulart Reis Filho, O quadro da arquitetura no Brasil, p. 192-194.

${ }^{153}$ No âmbito dos Estados, não obstante o pioneirismo do Estado do Paraná, que por meio da lei n. 112, de outubro de 1948, criou o Conselho Estadual do Patrimônio Histórico e Artístico, é considerável o número de órgãos de preservação surgidos na década de 1960, tais como o DPHA, no antigo Estado da Guanabara (1964), o IPHAE, no Rio Grande do Sul (1964), o FPACBA, na Bahia (1967), e o CONDEPHAAT, em São Paulo (1968). Na década seguinte, são criados o IEPHA, em Minas Gerais (1971), a FUNDARPE, em Pernambuco (1973) e a FCC, em Santa Catarina (1979). No plano municipal, é na década de 1980 que se amplia expressivamente o número órgãos e entidades especiais de preservação, como o CONPRESP, em São
} 
Em termos de programas governamentais, costuma ser lembrada a experiência de cerca de 10 anos do Programa Integrado de Reconstrução das Cidades Históricas, criado em 1973 por proposta do Ministério da Educação e Cultura e com a participação, no âmbito federal, dos Ministérios do Planejamento e da Indústria e Comércio (por meio da Embratur).

Contando com recursos do Banco Nacional de Habitação, com a atuação direta e descentralizada dos Estados e Municípios e com a referência conceitual e técnica do IPHAN, esse Programa "tinha [inicialmente] como objetivo criar infra-estrutura adequada ao desenvolvimento e suporte das atividades turísticas e ao uso de bens culturais como fonte de renda para regiões carentes do Nordeste, revitalizando monumentos em degradação"154.

Mais do que a simples restauração física de monumentos históricos espalhados pelo País, o "Programa de Cidades Históricas" - como ficou mais conhecido propunha o fortalecimento das bases do turismo nessas cidades e a articulação desta atividade com as necessidades locais de desenvolvimento econômico.

Essa ideia de aproveitamento do potencial turístico do patrimônio cultural para os fins de desenvolvimento econômico já vinha sendo amplamente debatida no nível internacional desde pelo menos 1967 , quando realizado um encontro da OEA para tratar da conservação e utilização de monumentos e lugares de interesse histórico e artístico. As conclusões deste encontro resultaram nas chamadas "Normas de Quito", que acerca desse tema dispuseram basicamente o seguinte:

Partimos do pressuposto de que os monumentos de interesse arqueológico, histórico e artístico constituem também recursos econômicos da mesma forma que as riquezas naturais do país. Consequentemente, as medidas que levam a sua preservação $e$ adequada utilização não só guardam relação com os planos de desenvolvimento, mas fazem ou devem fazer parte deles.

$[\ldots]$

Paulo (1985), o Conselho Municipal de Proteção do Patrimônio Cultural do Rio de Janeiro (1980), o CONDEPACC, em Campinas (1987), a Fundação Gregório de Matos, em Salvador (1986),

${ }^{154}$ Maria Cecília Londres Fonseca, O patrimônio em processo..., p. 143. 
Valorizar um bem histórico ou artístico equivale a habilitá-lo com as condições objetivas e ambientais que, sem desvirtuar sua natureza ressaltem suas características e permitam seu ótimo aproveitamento. Deve-se entender que a valorização se realiza em função de um fim transcendente, que, no caso da América Ibérica, seria o de contribuir para o desenvolvimento econômico da região.

$[\ldots]$

Os valores propriamente culturais não se desnaturalizam nem se comprometem ao vincular-se com os interesses turísticos e, longe disso, a maior atração exercida pelos monumentos e a fluência crescente de visitantes contribuem para afirmar a consciência de sua importância e significação nacionais.

$[\ldots]$

Os projetos de valorização do patrimônio monumental fazem parte dos planos de desenvolvimento nacional e, consequentemente, devem a eles se integrar. Os investimentos que se requerem para a execução dos referidos projetos devem ser feitos simultaneamente com os que são necessários para o equipamento turístico da zona ou região objeto de revalorização" (grifamos).

Nessa esteira, visando a esse aproveitamento do patrimônio cultural para o turismo e desenvolvimento, foram pensadas, no Brasil, formas mais abrangentes de lidar com a preservação patrimonial, baseadas em planos urbanísticos, como relata Paulo Ormindo de Azevedo:

A consciência de que só através do planejamento seria possível conservar as nossas cidades históricas não faltou aos fundadores do IPHAN. Para implementar uma nova política, Rodrigo Melo Franco de Andrade e Renato Soeiro, seu sucessor, promovem a incorporação da experiência europeia com convites a especialistas estrangeiros para discutir a questão e assessorar os primeiros planos urbanísticos de centros históricos no país. [...] foram elaborados planos diretores para Ouro Preto, São Luís do Maranhão, Alcântara, Parati, Salvador, São Cristóvão e Laranjeiras, entre outras cidades.

Muitos desses planos foram financiados e implementados, através de convênios com estados e municípios, pelo Programa das Cidades Históricas [...]. Consciente de que a questão da conservação do nosso 
patrimônio não poderia ser resolvida exclusivamente a partir de Brasília, a geração fundadora do IPHAN promove a descentralização e horizontalização do sistema [sic] preservação [...], ensejando a criação de numerosas fundações estaduais e algumas municipais de proteção ao patrimônio. ${ }^{155}$

Posteriormente, em 1977, o Programa de Cidades Históricas foi estendido para algumas localidades da região sudeste do País. Mas durou até 1983, encerrando-se, assim, um promissor processo de criação de uma política pública nacional de preservação de Cidades Históricas ${ }^{156}$.

Na década de 1990, projeto semelhante foi retomado pelo Poder Executivo federal, por meio do Programa Monumenta. Esse Programa contou com o apoio técnico-institucional da UNESCO e com recursos do Banco Interamericano de Desenvolvimento - BID para financiar ações integradas nessas localidades históricas. Tais ações visavam a oferecer condições de sustentabilidade a esse patrimônio cultural urbano e consistiam na: restauração de bens tombados; capacitação de mãode-obra; formação de agentes locais de cultura e turismo; promoção de programas educativos; e destinação de novos usos aos bens recuperados nessas cidades. Ao todo, 26 sítios foram beneficiados por esse Programa.

De abrangência ampliada, tem sido divulgada recentemente uma proposta do Poder Executivo federal que, se implementada, pretende dar continuidade aos objetivos do Programa Monumenta ${ }^{157}$ e beneficiar cerca de 173 Municípios. Os investimentos seriam estabelecidos segundo os Planos de Ação elaborados pelos municípios respectivos, com metas anuais ${ }^{158}$.

\footnotetext{
155 Paulo Ormindo de Azevedo. "Comentário 4: A cidade como obra aberta". In Victor Hugo Mori et alli (orgs), Patrimônio: Atualizando o debate, p. 67.

${ }^{156}$ Idem, ibidem, p. 67.

${ }^{157}$ Os investimentos do BID para o Programa Monumenta encerram-se no final do ano de 2009, devendo as ações correspondentes ser concluídas até o final do ano de 2010.

158 Trata-se do chamado "PAC das Cidades Históricas", lançado em outubro de 2009 pelo Governo Federal, tendo por objetivos principais: “1. Promover a requalificação urbanística dos sítios históricos e estimular usos que promovam o desenvolvimento econômico, social e cultural - que inclui ações de embutimento de fiação elétrica aérea, recuperação de espaços públicos com acessibilidade universal, instalação de mobiliário urbano e sinalização, iluminação de destaque e instalação de internet sem fio; 2. Investir na infra-estrutura urbana e social - o que vai permitir a inclusão das cidades históricas e seu entorno nas ações da Agenda Social do
} 
Todos esses Programas, inclusive este proposto mais recentemente, estabeleceram como condição para sua aplicação que essas localidades fossem tombadas pelo IPHAN ou ao menos estivessem em processo de tombamento federal.

Nesse aspecto, pensando-se em uma política nacional de preservação que compreenda de todo o patrimônio cultural urbano brasileiro, que garantisse aos bens que o integram mesmas oportunidades de captação de recursos financeiros de bancos de desenvolvimento, independentemente de avaliações de graus de relevância cultural envolvidos - se nacional, regional ou local -, sugerem-se duas remodelações desse requisito para os programas que se pretender implementar atualmente: uma primeira, consistente na não limitação das oportunidades investimentos apenas aos bens declarados oficialmente como culturais pela via do tombamento, dado que inúmeros são os mecanismos que hoje também podem, substitutivamente, formar do patrimônio cultural brasileiro. Uma segunda, relativa à abrangência também das localidades oficialmente reconhecidas como patrimônio cultural exclusivamente pelos órgãos estaduais ou municipais de preservação.

Nos dias atuais, verificam-se interações do IPHAN com órgãos preservacionistas dos Estados federados e dos Municípios, assim como com instituições acadêmicas e sociedade civil, voltadas à estruturação de um Sistema Nacional de Patrimônio Cultural, assim como à reflexão e construção conjunta de uma Política Nacional de Patrimônio Cultural. Trata-se da promoção de simpósios, reuniões e chamadas públicas com essas entidades buscando-se coletar informações, bem como discutir questões relevantes à realização desses objetivos.

governo federal. 3. Financiamento para recuperação de imóveis privados subutilizados ou degradados. 4. Recuperação de monumentos e imóveis públicos - que inclui a readequação de uso para abrigar universidades, escolas, bibliotecas, museus e outros espaços públicos. 5. Fomento às cadeias produtivas locais - que prevê apoio à estruturação de atividades produtivas, especialmente as atividades tradicionais. 6. Promoção nacional e internacional do patrimônio cultural representado pelas cidades históricas a partir do viés do turismo". De acordo com notícia veiculada na página eletrônica do Iphan, a meta de investimentos iniciais, no primeiro ano desse Programa, seria de cerca de R \$ 250 milhões. Além da União, por meio dos Ministérios do Turismo, da Educação e das Cidades, esse projeto contará com a participação da Eletrobras, do BNDES, da Petrobras, da Caixa Econômica Federal e do Banco do Nordeste do Brasil. Extraído da página eletrônica do Iphan: www.iphan.gov.br. Disponível em: http://portal.iphan.gov.br/portal/montarDetalheConteudo.do?id=14929\&sigla=Noticia\&retorno=detalheNotic ia. Acesso em: 09 dez. 2009. 
Mais adiante, no Capítulo 4, serão expostos de forma detalhada alguns instrumentos urbanísticos disponíveis ao Poder Executivo pelo Direito positivo brasileiro para fins de preservação do patrimônio cultural urbano.

\subsubsection{Controle jurisdicional}

A atividade jurisdicional constitui meio tipicamente repressivo de proteção ao patrimônio cultural brasileiro.

Analisando-se a linha evolutiva das ações preservacionistas a cargo do Poder Público desde a edição do Decreto-Lei $n^{\circ}$ 25/37, quando institucionalizada a tutela jurídica do patrimônio, verifica-se uma ampliação dos meios processuais de defesa desse patrimônio - tais como a ação civil pública e a ação popular -, assim como uma utilização crescente desses mecanismos para garantia da preservação de bens culturais.

Essa tendência contemporânea de ampliação das demandas judiciais por tutela do patrimônio cultural é atribuída a pelo menos duas razões distintas: uma primeira, consistente na já comentada ampliação do próprio objeto da preservação; e uma segunda razão, referente ao contemporâneo alargamento da noção de legalidade e, portanto, dos elementos passíveis de serem submetidos a avaliação e controle jurisdicional.

Três importantes instrumentos processuais podem ser mencionados como disponíveis no Direito positivo para a defesa dos bens integrantes do patrimônio cultural urbano pelo Poder Judiciário, quais sejam: a ação popular, a ação civil pública e a ação penal pública.

Prevista no artigo $5^{\circ}$, inciso LXXIII da Constituição de 1988 e disciplinada pela Lei Federal n ${ }^{\circ}$ 4.717, de 29 de junho de 1965, a ação popular consiste em mecanismo por meio do qual qualquer cidadão poderá propor judicialmente a anulação de atos lesivos ao patrimônio público praticados por entidade pública ou 
privada que o detenha, sendo assim também entendidos os bens e direitos de valor artístico, estético, histórico ou turístico ${ }^{159}$. Salvo comprovada má-fé, nesse tipo de ação, o autor fica isento de custas judiciais e do ônus da sucumbência.

A ação civil pública, por sua vez, é regida pela Lei Federal n ${ }^{\circ} 7.347$, de 24 de julho de 1985 e constitui instrumento processual próprio para tutela jurisdicional civil de bens e direitos metaindividuais, dentre os quais são previstos explicitamente os bens "de valor artístico, estético, histórico, turístico e paisagístico"160. O Estatuto da Cidade, preocupando-se em garantir a tutela judicial coletiva do equilíbrio urbano, também tratou de prever expressamente a ordem urbanística como bem suscetível de defesa pela Ação Civil Pública (artigos 53 e 54) ${ }^{161}$.

É nesse modo de ação que se destaca a importante e incisiva participação do Ministério Público em prol de interesses coletivos indisponíveis e de interesses $\operatorname{difusos}^{162}$, que quando não atua como parte no processo, exerce obrigatoriamente a função de fiscal da lei.

Além do Ministério Público, também possuem legitimidade para propor ação civil pública: a União, os Estados, os Municípios, as autarquias, as fundações, as sociedades de economia mista, assim como as associações constituídas há pelo menos um ano e que detenham uma finalidade institucional compatível com o objeto da demanda. Como sujeitos passivos dessa ação são admitidas quaisquer pessoas físicas ou jurídicas, públicas ou privadas -, que tenham causado ou ameaçado causar lesão a esses bens e direitos tutelados.

O objeto imediato da ação civil pública ajuizada será sempre a condenação civil do réu à indenização e/ou ao cumprimento de obrigações de fazer (tal como a realização de reformas para conservação do bem, ou a demolição de construção efetuada na vizinhança de bem tombado) e/ou de não fazer (tal como a não destruição

\footnotetext{
${ }^{159}$ Nos termos do art. $1^{\mathrm{o}}, \S 1^{\mathrm{o}}$ da Lei 4.717 , de 29 de junho de 1965.

${ }^{160}$ Art. $1^{\circ}$, inciso IV da Lei federal $n^{\circ} 7.347 / 85$.

${ }^{161}$ Cf. Carlos Ari Sundfeld, "O Estatuto da Cidade e Suas Diretrizes Gerais", In Adilson Abreu Dallari; Sérgio Ferraz (orgs.), Estatuto da Cidade: Comentários à Lei federal no 10.257/01, p. 55-56.

162 Trata-se de função institucional do Ministério Público prevista pelo art. 129, inciso III da Constituição Federal de 1988.
} 
ou mutilação do imóvel tutelado), sob pena de execução específica ou de cominação de multa diária, independentemente de requerimento por parte do autor.

Sobre esse aspecto, observa Hely Lopes Meirelles que

esta imposição judicial de fazer ou não fazer é mais racional que a condenação pecuniária, porque na maioria dos casos o interesse público é mais o de obstar a agressão ao meio ambiente ou obter a reparação direta e in specie do dano do que de receber qualquer quantia em dinheiro para a sua recomposição, mesmo porque quase sempre a consumação da lesão ambiental é irreparável, como ocorre no desmatamento de uma floresta natural, na destruição de um bem histórico, artístico ou paisagístico, assim como no envenenamento de um manancial, com a mortandade da fauna aquática ${ }^{163}$.

Com efeito, considerada a própria natureza difusa dos interesses tutelados pela ação civil pública, é de se deduzir que em muitos casos será consideravelmente dificultoso, quando não impossível, estabelecer-lhe um sucedâneo pecuniário. Como observa Rodolfo de Camargo Mancuso ao analisar o art. 11 da Lei 7.347/85, "a mens legis é a de conseguir, no limite do possível, que o poluidor, o fraudador, o vândalo, repare o mal feito, e para isso a lei dotou o juiz da possibilidade de impor astreintes" $" 164$.

Não há maiores controvérsias na jurisprudência quanto ao entendimento de que é dispensável o tombamento do imóvel para que ele possa ser objeto de proteção civil pelas vias judiciais.

Isso porque se entende que o reconhecimento da existência de um valor cultural referencial - e portanto legítimo de ser protegido - é tarefa que cabe aos três Poderes executar: Legislativo, Executivo e Judiciário. Assim, perfeitamente

\footnotetext{
${ }^{163}$ Mandado de Segurança, ação popular, ação civil pública, mandado de injunção, habeas data, ação direta de inconstitucionalidade, ação declaratória de constitucionalidade e argüição de descumprimento de preceito fundamental, p. 177.

${ }^{164}$ Ação Civil Pública - em defesa do meio ambiente, do patrimônio cultural e dos consumidores, p. 36. Grifos do autor.
} 


\author{
substituível o ato administrativo do tombamento pela decisão judicial declaratória da \\ existência de bem cujo valor cultural merece ser tutelado ${ }^{165}$.
}

Mesmo entendimento é o de Paulo Affonso Leme Machado, para quem, na ação civil pública,

\begin{abstract}
caso [os bens e direitos culturais] não estejam declarados pela Administração pública em categoria que os inclua na qualidade de bens e direitos tutelados, essa condição poderá ser conhecida e, portanto, provada no curso da ação. A lei não quis subtrair ao juiz a possibilidade de considerar dignos de proteção, bens e direitos cujo valor ainda não houvera sido protegido pela Administração Pública. Entender de outra forma seria retirar do Poder Judiciário a possibilidade de examinar lesão a direito individual, o qual, evidentemente, se enquadra, em âmbito maior, no direito social ${ }^{166}$.
\end{abstract}

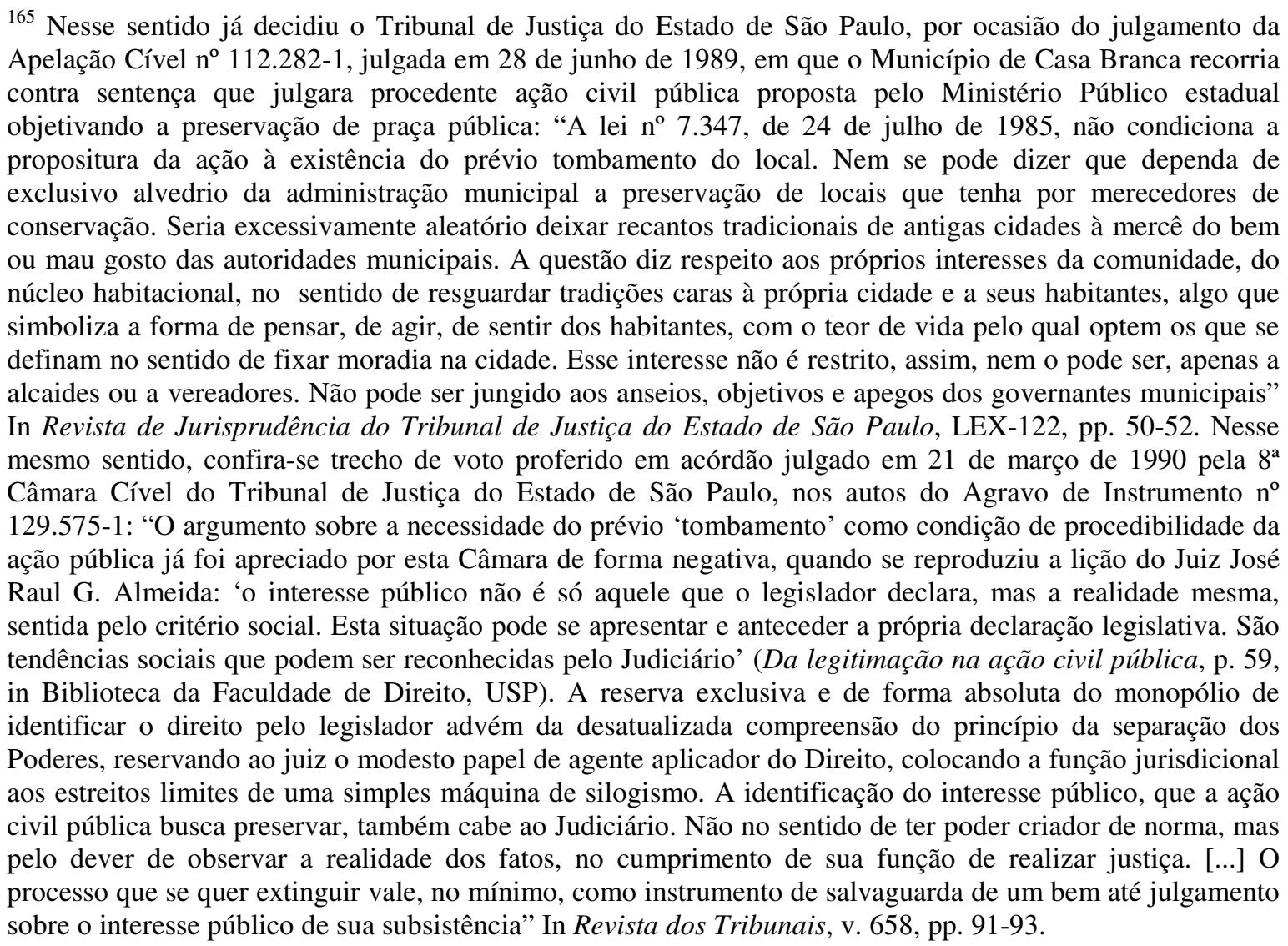

166 Ação Civil Pública e Tombamento, p. 15. Nessa mesma esteira, cf. Rodolfo de Camargo Mancuso: "no que tange a ser o tombamento um pré-requisito para a defesa do bem cultural em juízo, somos pela negativa, até porque tal ato não vem exigido como condição de admissibilidade para a ação civil pública, nem para a 
A ação civil pública e a ação popular, portanto, funcionam como verdadeiros instrumentos autônomos de proteção do patrimônio cultural brasileiro, independendo dos atos do Poder Executivo para reconhecer oficialmente a existência de um bem culturalmente referencial à sociedade e determinar obrigações de fazer e de não fazer aos réus da lide com vistas à proteção desse bem ${ }^{167}$.

Consistem em mecanismos pelos quais o Poder Judiciário, enquanto Poder Público, poderá corrigir e suplementar as eventuais omissões do Poder Executivo na execução da norma constitucional programática que determina a preservação estatal do patrimônio cultural. Contribuem, assim, para o atendimento da diretriz constitucional contida no art. 216, parágrafo primeiro da Constituição de 1988.

Por fim, a ação penal pública consiste em outra importante medida repressiva de proteção disponível no plano jurisdicional, que visa a conter os atos lesivos ao patrimônio cultural brasileiro. Por meio dela é possível a aplicação das sanções penais cominadas nos artigos 62 a 65 da Lei federal $n^{\circ} 9.605$, de 12 de fevereiro de $1998^{168}$, àqueles que cometerem os crimes de dano contra o patrimônio cultural definidos nesses mencionados dispositivos. A legitimidade ativa para propor esta ação é do Ministério Público, consoante a competência privativa estabelecida pelo artigo 129, inciso I da Constituição Federal de 1988.

Esses artigos 62 a 65 da Lei federal $n^{\circ} 9.605 / 98$ dispõem que constituem crime de dano contra o patrimônio cultural:

a) destruir, inutilizar ou deteriorar bem especialmente protegido por lei, ato administrativo ou decisão judicial;

\footnotetext{
ação popular" Ação Civil Pública em Defesa do Meio Ambiente, Patrimônio Cultural e dos Consumidores, p. 275.

${ }^{167}$ Em sentido contrário, entendendo que a proteção do patrimônio cultural só emerge do ato da autoridade administrativa ordenando o tombamento, cf. TJSP, Apelação Cível no 83211-1, Rel. Des. Ernani de Paiva, j. 19.03.1987. Há de ressalvar que se trata, todavia, de acórdão proferido sob a égide da Constituição anterior, em que ainda não constava expressamente a orientação de que múltiplos podem ser os modos de proteção do patrimônio cultural brasileiro.

${ }^{168}$ Esta Lei dispõe sobre as sanções penais e administrativas derivadas de condutas e atividades lesivas ao meio ambiente e dá outras providências.
} 
b) alterar o aspecto ou a estrutura de edificação ou local de valor cultural especialmente protegido por lei, ato administrativo ou decisão judicial sem autorização da autoridade competente ou em desacordo com a autorização concedida;

c) promover construção em solo não edificável em razão do seu valor cultural, ou no seu entorno, sem autorização ou em desacordo com a autorização concedida; e

d) Pichar, grafitar ou por outro meio conspurcar edificação, monumento urbano ou coisa tombada.

As penas cominadas para esses crimes variam desde detenção de três meses a um ano e multa, até reclusão de um a três anos e multa.

Com a entrada em vigor dessa Lei federal $n^{\circ}$ 9.605/98, foram revogados tacitamente os dispositivos do Código Penal até então aplicáveis à matéria (artigos 165 e 166). Essa lei trouxe modificações importantes ao tema de tutela penal do patrimônio cultural brasileiro.

Uma primeira refere-se ao fato dessa Lei ter retirado do objeto material desses tipos penais a condição de que o bem seja tombado - prevista até então - ampliandose, com isso, as oportunidades de tutela. De efeito, visando ajustar-se às diretrizes constitucionais, o legislador passou a tutelar todo e qualquer bem detentor de um valor cultural reconhecido oficialmente pelo Poder Público - seja pelo Poder Executivo, seja pelo Legislativo, seja pelo Poder Judiciário.

Uma segunda novidade trazida por essa Lei federal refere-se ao fato de se passar a admitir a modalidade culposa desses delitos, o que não existia até então.

E, enfim, uma terceira modificação importante diz respeito às penas cominadas para esses tipos penais, que se tornaram maiores que as até então cominadas pelo Código Penal.

Antes de encerrar este tópico 3.3.3, cabe mencionar a questão da possibilidade ou não do Poder Judiciário determinar aos órgãos estatais inadimplentes a 
implementação das políticas públicas estabelecidas pela Constituição. Sobre esse assunto, o Supremo Tribunal Federal tem firmado entendimento no sentido de que

Embora resida, primariamente, nos Poderes Legislativo e Executivo a prerrogativa de formular e executar políticas públicas, revela-se possível, no entanto, ao Poder Judiciário, determinar, ainda que em bases excepcionais, especialmente nas hipóteses de políticas públicas definidas pela própria Constituição, sejam estas implementadas pelos órgãos estatais inadimplentes, cuja omissão - por importar em descumprimento dos encargos político-jurídicos que sobre eles incidem em caráter mandatório - mostra-se apta a comprometer a eficácia e a integridade de direitos sociais e culturais impregnados de estatuta constitucional. A questão pertinente à reserva do possível. ${ }^{169}$

\subsection{Colaboração da comunidade}

Preliminarmente, há de se referir que a Constituição de 1988 foi elaborada e promulgada em um contexto em que se ampliava e se consolidava o processo democrático brasileiro, logo depois de um longo período em que vivenciada uma ditadura militar no País.

Nesse cenário, o constituinte de 1988 tratou de dispor, ao lado das garantias e dos direitos individuais e do direito de petição aos Poderes Públicos, alguns mecanismos de participação política direta, quais sejam, o referendo, o plebiscito e a iniciativa popular ${ }^{170}$.

Também estabeleceu, de maneira inédita, a participação da sociedade nas ações públicas voltadas à realização de alguns direitos contidos no Título VIII da Constituição de 1988 - referente à "Ordem Social” -, mais especificamente daqueles

\footnotetext{
169 Recurso Extraordinário no 436.996-AgR, Rel. Min. Celso de Mello, j. 22 nov. 2005. Nesse mesmo sentido, Recurso Extraordinário no 595.595-AgR, Rel. Min. Eros Grau, j. 28 abr. 2009.

${ }^{170}$ Arts. 50, XV e 61, $\$ 2^{\circ}$ da Constituição de 1988. Cf. Marcos Jordão Teixeira do Amaral, "Da gestão democrática da cidade", In Odete Medauar; Fernando Dias Menezes de Almeida (coord.), Estatuto da Cidade: Lei 10.257/01, Comentários, p. 260.
} 
relativos à educação, à cultura e ao meio ambiente ecologicamente equilibrado ${ }^{171}$. De efeito, porquanto modos de manifestação do direito ao bem-estar e à qualidade de vida humana, esses direitos necessitam ser formados garantindo-se o envolvimento da sociedade nos processos respectivos, a fim de que eles representem - o mais aproximadamente possível - os reais anseios desta.

Com relação ao patrimônio cultural brasileiro, o constituinte de 1988 previu essa participação social nos seguintes termos:

Art. 216. $\S 1^{\circ} \mathrm{O}$ poder público, com a colaboração da comunidade, promoverá e protegerá o patrimônio cultural brasileiro, por meio de inventários, registro, vigilância, tombamento e desapropriação e de outras formas de acautelamento e preservação.

Essa norma constitucional determina que o Poder Público, quando das suas decisões envolvendo a preservação do patrimônio cultural brasileiro, assegure a participação da sociedade e leve em conta as opiniões e contribuições oferecidas por esta. As políticas públicas nessa matéria, portanto, deverão ser feitas em moldes participativos, conferindo-se, de alguma forma, um mínimo de envolvimento da população nas ações preservacionistas, assim como nas decisões acerca de quais bens preservar.

Isso com vistas a garantir que o patrimônio instituído e tutelado pelo Estado represente efetivamente - e de forma equilibrada - os valores referenciais aos diferentes grupos formadores da sociedade brasileira e que, ao mesmo tempo, ele se preserve integrado na vida social. É que, como conclui Isaura Botelho, "não se trata de colocar a cultura (que cultura?) ao alcance de todos, mas de fazer com que todos

\footnotetext{
171 Assim: "Art. 205. A educação, direito de todos e dever do Estado e da família, será promovida e incentivada com a colaboração da sociedade, visando ao pleno desenvolvimento da pessoa, seu preparo para o exercício da cidadania e sua qualificação para o trabalho. [...] Art. 225. Todos têm direito ao meio ambiente ecologicamente equilibrado, bem de uso comum do povo e essencial à sadia qualidade de vida, impondo-se ao Poder Público e à coletividade o dever de defendê-lo e preservá- lo para as presentes e futuras gerações.
} 
os grupos possam viver sua própria cultura [...], pois o público é o conjunto de públicos diferentes [..." ${ }^{\prime 172}$.

Acerca dessa participação social em matéria de preservação patrimonial, Bernardo Novais da Mata-Machado bem observa que

Antes da Constituição de 1988, os bens passíveis de proteção legal estavam limitados àqueles de excepcional valor e que faziam referência a fatos memoráveis da história do Brasil. Nesse contexto, era mais fácil justificar e obter consenso em torno da preservação desses bens. Mas se mesmo antes já se ressentia de uma participação mais efetiva das comunidades atingidas, hoje, com a possibilidade de estender-se a proteção patrimonial a bens materiais e imateriais de regiões, municípios, bairros e até mesmo a referências pontuais, não é mais possível abrir mão da presença direta dos interessados. ${ }^{173}$

A complexidade cultural contemporânea, manifestada no modo amplo como definido o patrimônio cultural brasileiro na Constituição Federal de 1988, está a exigir, assim, participações diretas e paritárias da sociedade nos assuntos atinentes à defesa desse seu patrimônio. Nessa tarefa, no entanto, sempre se configurará um desafio fazer com que essa participação aconteça sem cooptações ou manipulações.

No âmbito das cidades, dentro do espírito da Constituição de 1988 de garantia do Estado Democrático de Direito, a Lei federal $n^{\circ}$ 10.257/01 também deixou claro que as políticas de desenvolvimento urbano executadas pelos Municípios deveriam ter como fundamento essencial a gestão democrática, admitindo a participação de

172 "As dimensões da cultura e o lugar das políticas públicas", p. 27. Disponível em: http://www.centrodametropole.org.br/pdf/Isaura.pdf. Acesso em: 20 dez. 2009.

173 "Participação Política e Conselhos de Cultura: Uma proposta". In Hamilton Faria, Altair Moreira e Fernanda Versolato (orgs.), Você Quer um Bom Conselho?: Conselhos Municipais de Cultura e Cidadania Cultural, p. 68. Disponível em: http://www.polis.org.br/publicacoes_lista.asp?cd_serie=6. Acesso em: 20 dez. 2009. A Declaração Universal dos Direitos do Homem, de 1948, prescreve, em seu art. 27 que "toda pessoa tem o direito de participar livremente da vida cultural da comunidade, de gozar das artes e de aproveitar-se dos progressos científicos e dos benefícios que dele resultam". E a Recomendação sobre a Participação dos Povos na Vida Cultural (1976), da UNESCO, definiu duas dimensões dessa participação: a dimensão ativa (direito à livre criação) e dimensão passiva (direito à livre fruição). Restringindo mais o alcance da noção de participação, tem-se a Declaração do México sobre as Políticas Culturais (1983), que traduz participação política tão somente como atos de tomada de decisões políticas. Desse modo, fica garantido aos indivíduos e à sociedade participar do processo de "tomada de decisões relativos à vida cultural, recomendando, para tanto, "multiplicar as ocasiões de diálogo entre a população e os organismos culturais". 
diferentes atores sociais, de modo a se fazer valer as funções sociais da cidade e da propriedade $^{174}$.

Assim, o Capítulo I dessa Lei afirmou expressamente o princípio democrático como um dos seus princípios gerais. E o Capítulo IV previu a gestão democrática da cidade como diretriz operacional dessa nova ordem jurídico-urbanística ${ }^{175}$, dispondo em seu artigo 43 que:

Art. 43. Para garantir a gestão democrática da cidade, deverão ser utilizados, entre outros, os seguintes instrumentos:

I - órgãos colegiados de política urbana, nos níveis nacional, estadual e municipal;

II - debates, audiências e consultas públicas;

III - conferências sobre assuntos de interesse urbano, nos níveis nacional, estadual e municipal;

IV - iniciativa popular de projeto de lei e de planos, programas e projetos de desenvolvimento urbano;

$\mathrm{V}-($ vetado).

Esse rol definido pelo legislador é meramente exemplificativo, sendo possível a adoção destes e/ou de outros mecanismos democráticos de gestão aqui não explicitados. De efeito, o sentido imperativo da expressão "deverão ser", contida no caput deste dispositivo, refere-se à garantia de gestão democrática, e não propriamente ao emprego mínimo dos meios arrolados nesses incisos.

$\mathrm{O}$ inciso $\mathrm{V}$ desse dispositivo referia-se aos mecanismos do referendo e do plebiscito. Seu veto poderia sugerir que esse rol do artigo 43 fosse taxativo - daí

\footnotetext{
${ }^{174}$ Cf. Leonardo Barci Castriota, "Intervenções sobre o patrimônio urbano: modelos e perspectivas", In Forum Patrimônio..., v.1, n.1, p. 24. A propósito, recorda Maria Paula Dallari Bucci que o Estatuto da Cidade "resulta, ele próprio, de uma longa história de participação popular, iniciada na década de 80, e que teve grande influência na redação do capítulo da política urbana da Constituição Federal (arts. 182-183)". "Gestão Democrática da Cidade", In Adilson Abreu Dallari; Sérgio Ferraz (coord.), Estatuto da Cidade..., p. 336-337

${ }^{175}$ Cf. Maria Paula Dallari Bucci, "Gestão Democrática da Cidade”, In Adilson Abreu Dallari; Sérgio Ferraz (coord.), Estatuto da Cidade..., p. 336.
} 
justificando a necessidade de exclusão de um mecanismo dessa relação. Mas a Mensagem $\mathrm{n}^{\circ}$ 730, de 10 de julho de 2001, do Poder Executivo federal, esclarece a questão ao expor, como razões desse veto, a mera observância da "boa técnica legislativa", sob o argumento de que a Lei federal no 9.709/98 já autorizaria a utilização desses dois instrumentos democráticos em todas as questões de competência dos Municípios ${ }^{176}$. Mas se esta é realmente a razão de ser do veto, não se compreende por que mantido o inciso IV do texto legal, por exemplo, cujo mecanismo indicado é igualmente regido por essa mesma lei referida ${ }^{177}$.

De todo modo, não obstante essa inconveniente omissão na Lei, o Poder Público municipal não deve deixar de utilizar esses dois mecanismos em suas ações urbanísticas, inclusive nas que atinem à preservação de bens culturais, a fim de que sejam amplas "as oportunidades de consulta aos habitantes da cidade sobre assuntos do seu interesse" 178 , bem como para que se admitam modos deliberativos de participação, já que os demais instrumentos relacionados exemplificativamente nesse dispositivo são meramente consultivos.

Essa diretriz democrática para as políticas de gestão das cidades é também explícita nas seções desta Lei que definem os regimes gerais de vários instrumentos de política urbana, tais como no estudo de impacto de vizinhança (em que se garante à população interessada a consulta aos documentos desse Estudo - que esclarece os potenciais impactos dos empreendimentos ou atividades intentados em áreas urbanas determinadas) ${ }^{179}$; nas operações urbanas consorciadas (que têm como elemento

\footnotetext{
${ }^{176}$ A Lei 9.709/98 regulamenta a execução do plebiscito, do referendo e da iniciativa popular. Dispõe seu artigo $6^{\circ}$ que: "Nas demais questões, de competência dos Estados, do Distrito Federal e dos Municípios, o plebiscito e o referendo serão convocados de conformidade, respectivamente, com a Constituição Estadual e com a Lei Orgânica.”.

177 Conforme também observado por Maria Paula Dallari Bucci, "O argumento técnico [do veto] é inconsistente, diga-se, na medida em que a menção aos instrumentos da gestão democrática neste capítulo do Estatuto da Cidade tem finalidade de sistematizar o assunto em relação ao objeto da lei a gestão da cidade - que delimita um interesse específico e cria um campo de aplicação peculiar. A se admitir o fundamento do veto em seu suposto rigor, deveriam ser vetados, pelo menos em parte, também o inciso II, posto que as audiências e consultas públicas são disciplinadas pela Lei de Processo Administrativo (Lei federal 9.784/1999) e o inciso IV, uma vez que o art. 61, $\S 2^{\circ} \mathrm{da}$ Constituição Federal já disciplinou a iniciativa popular de projeto de lei”. Op. Cit., p. 351.

${ }^{178}$ Maria Paula Dallari Bucci, "Gestão Democrática da Cidade”, In Adilson Abreu Dallari; Sérgio Ferraz (coord.), Estatuto da Cidade..., p. 351.

179 “Art. 37. [...], § único. Dar-se-á publicamente aos documentos integrantes do EIV, que ficarão disponíveis para consulta, no órgão competente do Poder Público municipal, por qualquer interessado."
} 
essencial a participação dos proprietários, moradores, usuários permanentes e investidores privados nas intervenções urbanísticas do Poder Público municipal voltadas à melhoria urbanística de áreas da cidade) ${ }^{180}$; e no plano diretor (em que se deverá garantir, no seu processo de elaboração e na fiscalização de sua implementação, a realização de audiências públicas e debates com a sociedade, a publicidade e o amplo acesso dos documentos e informações produzidos) ${ }^{181}$.

E mesmo nos casos dos instrumentos de política urbana cujos regimes gerais não contenham previsão expressa nesse sentido, essa ampla participação deve ser assegurada sempre que possível, com fundamento no art. 43 já transcrito acima.

Nos Estados Unidos, em localidades onde adotado o Programa de Transferable of Development Rights (TDR) para proteção de bens históricos - cujo modo de operar assemelha-se ao instituto brasileiro da "transferência do direito de construir"182 -, o poder público exerce trabalho conjunto com a comunidade residente para determinar quais áreas na cidade serão destinadas ao desenvolvimento e quais serão $\operatorname{preservadas}^{183}$.

Na Convenção Europeia da Paisagem ${ }^{184}$, de 20 de outubro de 2000, definiu-se que os Estados signatários estabeleceriam procedimentos para a participação do público em geral - além de autoridades locais e regionais, e de outras partes interessadas - na definição e implementação de políticas de paisagem.

\footnotetext{
180 “Art. 32. [...], $\$ 1^{\circ}$. Considera-se operação urbana consorciada o conjunto de intervenções e medidas coordenadas pelo Poder Público municipal, com a participação dos proprietários, moradores, usuários permanentes e investidores privados, com o objetivo de alcançar em uma área transformações urbanísticas estruturais, melhorias sociais e a valorização ambiental."

181 “Art. 40. [...], $4^{\circ}$. No processo de elaboração do plano diretor e na fiscalização de sua implementação, os Poderes Legislativo e executivo municipais garantirão: I - a promoção de audiências públicas e debates com a participação da população e de associações representativas dos vários segmentos da comunidade; II - a publicidade quanto aos documentos e informações produzidos; III - o acesso de qualquer interessado aos documentos e informações produzidos."

${ }^{182}$ Que será mais detalhadamente abordado no Capítulo 4 deste trabalho.

${ }^{183}$ Cf. Transferable Development Rights (TDR). Model Iniciatives. Democratic Leadership Council Website, 30/06/08. Disponível em: http://www.dlc.org/ndol_ci.cfm?kaid=139\&subid=274\&contentid=250739. Acesso em: 6 nov. 2009. Este artigo noticia que até 2003, haviam sido implementados 134 programas de TDR em 25 estados norte-americanos.

184 Conselho da Europa. Convenção Europeia de paisagem. 2000. Art. 5º, c). Disponível em: http://www.gddc.pt/siii/docs/dec4-2005.pdf. Acesso em: 27 dez. 2009.
} 
Essa norma convencional europeia foi absorvida pelo atual Código Italiano dos Bens Culturais e da Paisagem (Decreto legislativo de 22 de janeiro de 2004, $\mathrm{n}^{\mathbf{o}}$ 42) nos seguintes termos:

144. Publicidade e participação. 1. Nos procedimentos de aprovação dos planos paisagísticos são assegurados a harmonização institucional, a participação dos sujeitos interessados e das associações constituídas para a tutela dos interesses difusos, identificadas consoante o artigo 13 da lei de 8 de julho de 1986, n. 349, e amplas formas de publicidade. Para tal fim, as regiões disciplinarão mediante disposições legais específicas os procedimentos de planejamento paisagístico, em particular estabelecendo que a partir da data de adoção ou aprovação preliminar do plano, por parte da junta regional ou do conselho regional, não são consentidas nos imóveis e nas áreas referidos no artigo 134 intervenções que contrastem com as prescrições de tutela previstas para estes no plano em questão. ${ }^{185}$

A participação da comunidade também pode ser realizada indiretamente, por representação do Ministério Público e de associações civis sem fins lucrativos. O primeiro legitima-se como Instituição que traduz as pretensões da sociedade nessa seara, fiscalizando por meio de inquéritos civis, ações civis públicas, termos de ajustamento de conduta, etc, as políticas de preservação implementadas pelo Poder Executivo. As associações civis, por sua vez, além do importante papel na promoção do patrimônio cultural, também estão legitimadas juridicamente, como visto, a propor ações civis públicas em favor desses interesses de tutela.

\footnotetext{
185 (traduzimos). No original: “144. Pubblicità e partecipazione. - 1. Nei procedimenti di approvazione dei piani paesaggistici sono assicurate la concertazione istituzionale, la partecipazione dei soggetti interessati e delle associazioni costituite per la tutela degli interessi diffusi, individuate ai sensi dell'articolo 13 della legge 8 luglio 1986, n. 349 e ampie forme di publicità. A tale fine le regioni disciplinano mediante apposite norme di legge i procedimenti di pianificazione paesaggistica, in particolare stabilendo che a fare data dall'adozione o approvazione preliminare del piano, da parte della giunta regionale o del consiglio regionale, non sono consentiti per gli immobili e nelle aree di cui all'articolo $134 \mathrm{gli}$ interventi in contrasto con le prescrizioni di tutela per essi previste nel piano stesso."
} 


\title{
Capítulo 4 OS MEIOS: COMO É POSSÍVEL PRESERVAR O PATRIMÔNIO CULTURAL URBANO?
}

\begin{abstract}
Para orientar as responsabilidades do poder público em relação ao patrimônio ambiental urbano, a legislação, as instituições e as práticas deveriam operar tendo como quadro o território da cidade e seus atributos diferenciais e, como alvo, criar condições favoráveis para qualificar as práticas de seus cidadãos
\end{abstract}

Ulpiano Bezerra de Meneses ${ }^{186}$

Atualmente, considerada a diversidade dos bens compreendidos na concepção constitucional de patrimônio cultural brasileiro (artigo 216, caput e incisos I a V), claro está que não é mais possível admitir que a tutela estatal desse patrimônio seja exercida mediante a aplicação de um mesmo e único tipo de mecanismo, para todos os casos. Assim é que a própria Constituição de 1988, depois de detalhar o conteúdo dessa concepção de patrimônio, tratou de arrolar uma série de instrumentos passíveis de serem aplicados aos fins da preservação.

Para que sejam recordados os exatos termos do dispositivo em comento:

Art. 216. [...]

$1^{\circ}$. O poder público, com a colaboração da comunidade, promoverá e protegerá o patrimônio cultural brasileiro, por meio de inventários, registros, vigilância, tombamento e desapropriação, e de outras formas de acautelamento e preservação.

\footnotetext{
${ }^{186}$ Ulpiano Toledo Bezerra de Meneses, "A cidade como bem cultural”, In Victor Hugo Mori et alli (orgs.), Patrimônio: Atualizando o Debate, p. 41.
} 
Do quanto disposto pelo constituinte, depreende-se que a ampla preservação do patrimônio cultural, para sua perpetuação ao longo das gerações, deve ser empreendida contando-se com duas modalidades distintas de ação do Estado, quais sejam, a promoção e proteção desse patrimônio. De efeito, preservação é conceito genérico e nela é possível compreender "toda e qualquer ação do Estado que vise conservar a memória de fatos ou valores culturais de uma Nação"187.

Por promoção entende-se não somente toda e qualquer ação estatal de fomento, estímulo ou difusão dos valores culturais, como também a própria formação do patrimônio cultural, que se faz pela designação específica pela autoridade competente dos bens que deverão integrá-1o ${ }^{188}$. Assim seriam as ações de inventariação, registro e catalogação de bens, a difusão de conhecimentos sobre o patrimônio, a realização de eventos públicos, etc.

Já a proteção compreende tanto a ação estatal preventiva, consistente nas medidas que impeçam a ocorrência de danos a bens culturais ameaçados - portanto, muitas vezes limitadoras de direitos individuais -, quanto a ação repressiva, relativa a ações que visam a reparar o dano já ocorrido (quando possível a reparação), assim como punir o agente causador do dano, aplicando-lhe sanções - é o caso das ações judiciais já comentadas.

A Constituição de 1988, ao impor ao Poder Público prestações de preservação do patrimônio cultural brasileiro, sugeriu que elas fossem integradas entre si, tanto as de promoção, quanto as de proteção. Tanto as fomentadoras, quanto as fiscalizadoras e sancionadoras, permitindo com isso aproximar esse patrimônio da sociedade para quem originalmente ele é considerado referência cultural, e assim procurando assegurar a integridade e a perenidade desses bens na vida e na memória das comunidades formadoras da sociedade brasileira.

No contexto das cidades, muitos dos valores culturais hoje nelas presentes são assim concebidos não tanto em razão de aludirem a fatos históricos memoráveis ou exemplares excepcionais da aplicação de técnicas artísticas consagradas,

\footnotetext{
${ }^{187}$ Sonia Rabello de Castro, O Estado na preservação de bens culturais: o tombamento, p. 5.

${ }^{188}$ José Afonso da Silva, Ordenação Constitucional da Cultura, p. 116.
} 
manifestados em um artefato material, mas principalmente pelas significações afetivas que este artefato pode oferecer aos habitantes e usuários da cidade nas interações destes com aquele e seu meio. Essas significações afetivas, na medida em que são capazes de proporcionar bem-estar e contribuir para a qualidade de vida no meio urbano, passam a constituir para a ordem vigente, do mesmo modo que aqueles valores históricos expressos em documentos, verdadeiros fundamentos à ação estatal tutelar sobre elas.

Ao mesmo tempo, a atividade urbanística, tipicamente interventiva sobre o domínio privado e fundamentada no princípio da supremacia do interesse público sobre o particular, realiza a ordenação e o controle do uso do espaço urbano tendo por finalidade última essa mesma garantia de bem-estar, assim como a qualidade de vida no ambiente urbano.

Ocorre que a visão isolada que o instituto do tombamento tradicionalmente dispensa aos bens sob sua tutela, somada ao modo indistinto como este instrumento vem sendo aplicado nos últimos tempos, para praticamente todos casos em que se pretende promover e proteger bens culturais, evidenciam as limitações deste mecanismo para dar conta, sozinho, da tutela das múltiplas espécies de interesses culturais presentes no ambiente urbano.

Em obra publicada em 1979, Jean-Benoit Bleyon já observava que a política francesa de salvaguarda do patrimônio arquitetônico urbano era caracterizada pela coexistência dos modos de proteção tradicionais e de novos modos de salvaguarda, explicando que aqueles constituíam as medidas de proteção pontuais, e estes, as medidas planificadas de salvaguarda ${ }^{189}$. A salvaguarda planificada do patrimônio arquitetônico urbano permitiria uma ação verdadeiramente eficaz, posto que asseguraria, ao mesmo tempo, a restauração dos monumentos e dos sítios históricos (proteção) e a integração deles no ambiente urbano (promoção) ${ }^{190}$.

\footnotetext{
${ }^{189}$ L'Urbanisme et La Protection des Sites: La Sauveguarde du Patrimoine Architectural Urbain, p. 169.

${ }^{190}$ Idem, ibidem, p. 169.
} 
Sem a pretensão de esgotar a análise dos inúmeros impasses existentes em matéria de preservação do patrimônio cultural urbano - já que isso transcenderia em muito uma avaliação exclusivamente jurídica -, o que se propõe neste Capítulo são basicamente dois feitos: um primeiro é apontar ideia já há algum tempo sedimentada nos debates internacionais, assim como em outros campos científicos, especialmente no de arquitetura e urbanismo, qual seja, de que as soluções para a gestão do patrimônio cultural das cidades devem ser buscadas empregando-se uma visão urbanística sobre o tema, ou seja, pelas vias da preservação integrada ao planejamento urbano. Um segundo intento, consiste em demonstrar que o ordenamento jurídico brasileiro oferece hoje uma interessante gama de instrumentos urbanísticos para os fins de preservação do patrimônio cultural, ainda que a matéria, como um todo, reconhecidamente careça de sistematização legal de âmbito nacional.

Abaixo, portanto, será analisado preliminarmente o mecanismo de preservação adotado pela UNESCO, em especial as propostas e recomendações feitas pelo Comitê do Patrimônio Mundial para as cidades históricas brasileiras declaradas Patrimônio da Humanidade, na medida em que nessas manifestações são evidenciadas as preocupações da comunidade internacional com a conservação integrada e planejada dessas cidades históricas.

Seguidamente, se procederá à exposição dos instrumentos urbanísticos considerados essenciais à preservação planejada do patrimônio cultural urbano. Todos eles foram ao menos referidos pela Lei 10.257/01 (Estatuto da Cidade) como típicos instrumentos de política urbana, ainda que os regimes de alguns deles encontrem-se detalhados em leis esparsas e vigentes desde muito tempo antes de 1988, situação que, somada à ausência da lei nacional sistematizadora, pode gerar questionamentos, na prática, quanto ao alcance dos efeitos desses instrumentos; quanto aos objetos para os quais eles são mais apropriados; quanto à possibilidade ou não deles serem conciliados entre si; quantos aos deveres e garantias aos proprietários e à vizinhança dos bens de interesse cultural, etc. 


\subsection{A Proteção Internacional do Patrimônio Cultural da Humanidade}

A Convenção para a Proteção do Patrimônio Mundial, Cultural e Natural, de 1972, é considerada o mais popular documento normativo da UNESCO, em matéria de patrimônio, não somente pelo número de Estados signatários (até junho de 2009, somavam-se 186), como pelo número de sítios inscritos na Lista do Patrimônio Mundial (incluídas as decisões anunciadas na última reunião do Comitê do Patrimônio Mundial, somam-se ao todo 890 sítios, dos quais 689 são culturais, 176 são naturais e 25 são mistos) ${ }^{191}$.

De alto impacto junto à opinião pública, essa Convenção estabelece um sistema de proteção coletiva, de nível planetário, aos bens eleitos por um comitê internacional ("Comitê do Patrimônio Mundial") como "Patrimônio da Humanidade", nas categorias cultural ou natural, de acordo com os critérios da excepcionalidade do valor universal e da autenticidade do bem ${ }^{192}$.

A UNESCO adota como princípio fundamental a justificar essa sua ação tutelar a concepção de que "o patrimônio cultural de cada um é o patrimônio cultural de todos" ${ }^{193}$, ou seja, de que há determinado conjunto de bens, de uma região ou de um país, cujo valor é excepcional não somente para a respectiva comunidade, mas também para todos os povos do mundo.

191 Cf. informações disponíveis em: http://www.brasilia.unesco.org/noticias/releases/patrimoniomundial-ganha-13-novos-sitios. Matéria de 30.06.2009. Acesso em: 10 dez. 09 e http://www.brasilia.unesco.org/noticias/releases/brasilia-sediara-reuniao-do-comite-do-patrimoniomundial-em-2010/?searchterm=patrimonio mundial. Acesso em: 10 dez. de 2009.

192 Cf. Flavio Lopes, "Evolução do pensamento contemporâneo através da leitura de normas internacionais", In Patrimônio Arquitetônico: Cartas, Recomendações e Convenções Internacionais, p. 31. Conforme aponta este autor, ao longo dos quase 40 anos de existência da Convenção, esses critérios vêm sendo objeto de profunda reflexão. O Documento de Nara (1994) é resultado de um desses debates, a respeito do critério da autenticidade. Cf. também Fernando Fernandes da Silva, As cidades brasileiras e o patrimônio cultural da humanidade, p. 93-96.

${ }^{193}$ Cf. Documento de Nara, UNESCO, 1994, item 8. 
Diante desse princípio, implicaria essa salvaguarda internacional a responsabilidade da UNESCO pela conservação dos bens culturais que ela nomeasse como Patrimônio da Humanidade?

A resposta a essa indagação é claramente negativa. A ação internacional de salvaguarda não substitui o dever próprio dos Estados de zelar pela conservação de um patrimônio que, antes de ser de todos, é genuinamente deles. Os Estados signatários da Convenção firmaram compromisso com a UNESCO no sentido de garantirem a manutenção de seus bens, sendo o cumprimento desse dever pelos Estados, inclusive, uma das condições para inscrição de bens na Lista do Patrimônio Mundial $^{194}$.

Os organismos internacionais, de modo geral, devem respeitar a soberania dos Estados. No caso da UNESCO, essa máxima é prevista no parágrafo $3^{\circ}$ do artigo $1^{\circ}$ de sua Constituição:

Com vistas à preservação da independência, da integridade e da diversidade frutífera das culturas e dos sistemas educacionais dos Estados Membros da Organização, fica a ela vedada a intervenção nas questões essencialmente restritas à jurisdição interna desses Estados. ${ }^{195}$

A atividade supranacional vem, assim, tão somente cooperar com as ações preservacionistas desenvolvidas pelos Estados signatários em seus respectivos territórios - por suas formas próprias e soberanas de ação e repartição das atribuições -, mas nunca substituí-las ${ }^{196}$.

\footnotetext{
${ }^{194}$ Fernando Fernandes da Silva, Op. cit., p. 96.

195 Constituição da Organização das Nações Unidas para a Educação, a Ciência e a Cultura. UNESCO, 2002. Disponível em: http://unesdoc.unesco.org/images/0014/001472/147273POR.pdf. Acesso em 3 dez. 2009.

${ }^{196}$ Nesse sentido, cf. Preâmbulo e art. $4^{\text {o }}$ da Convenção: “[...] Considerando que, diante da amplitude e da gravidade dos novos perigos que os ameaçam, cabe à coletividade internacional participar da proteção do patrimônio cultural e natural de valor universal excepcional, prestando assistência coletiva que, sem substituir a ação do Estado interessado, irá completá-la eficazmente; [...] Art. $4^{\circ}$. Cada Estado-parte da presente Convenção reconhece que lhe compete identificar, proteger, conservar, valorizar e transmitir às gerações futuras o patrimônio cultural e natural situado em seu território. $\mathrm{O}$ Estado-parte envidará esforços nesse sentido, tanto com recursos próprios, como, se necessário,
} 
A Convenção do Patrimônio Mundial preconiza quatro princípios basilares, a conduzirem as ações dela decorrentes, quais sejam:

a) o pleno respeito à soberania dos Estados em cujo território situam-se os bens culturais e aos direitos desses Estados sobre os referidos bens, conforme a legislação nacional respectiva (art. $6^{\circ}$, $\left.\S 1^{\circ}\right)$;

b) o compromisso de cada Estado-parte de identificar, conservar, proteger, valorizar os bens culturais presentes em seu território e inscritos na Lista do Patrimônio Mundial, assim como de adotar, em seus países, uma política geral que atribua função ao patrimônio cultural na vida coletiva e que integre sua proteção aos programas de planejamento (arts. $3^{\circ}, 4^{\circ}$ e $\left.5^{\circ}, a\right)$;

c) o dever de cooperação e apoio da comunidade internacional com a identificação, proteção, conservação e valorização dos bens inscritos na Lista do Patrimônio Mundial, sempre que requerido pelo Estado-parte $\left(\operatorname{art} .6^{\circ}, \S \S 1^{\circ}\right.$ e $\left.2^{\circ}\right)$; e

d) o compromisso de todos os Estados-partes na Convenção de não tomar qualquer medida que ameace direta ou indiretamente os bens integrantes da Lista $\left(\operatorname{art.} 6^{\circ}, \S 3^{\circ}\right) .{ }^{197}$

As ações internacionais de que trata a Convenção do Patrimônio Mundial resumem-se a:

a) estudos sobre problemas artísticos, científicos e técnicos levantados pela proteção, conservação, revalorização e reabilitação do patrimônio cultural;

b) serviços de perícia, técnicos e de mão-de-obra qualificada;

mediante assistência e cooperação internacionais às quais poderá recorrer, especialmente nos planos financeiro, artístico, científico e técnico".

${ }^{197}$ Cf. Fernando Fernandes da Silva. Op. cit., p. 92-93. 
c) formação de especialistas em identificação, proteção, observação, revalorização e reabilitação do patrimônio cultural;

d) fornecimento de equipamento que o Estado interessado não possua ou não tenha condições de adquirir;

e) empréstimos a juros reduzidos, sem juros ou reembolsáveis a longo prazo; ou até mesmo subvenções não-reembolsáveis, em casos excepcionais e especialmente motivados, operações estas suportadas pelo Fundo do Patrimônio Mundial. O financiamento é parcial, cabendo ao Estado beneficiário o levantamento da maior parte dos recursos. ${ }^{198}$

As observações feitas até aqui demonstram o quão impróprio é o uso da expressão "tombamento" para designar as ações da UNESCO de salvaguarda das localidades brasileiras declaradas Patrimônio da Humanidade.

De efeito, o tombamento é instituto jurídico criado no nosso ordenamento pelo Decreto-Lei $n^{\circ}$ 25/37 para ser aplicado nos limites do território nacional e pela Administração Pública brasileira. Possui natureza jurídica de limitação administrativa, fundada no poder de polícia do Estado, e produz como efeitos obrigações de fazer e de não fazer aos proprietários dos bens culturais.

Já a UNESCO, como visto, não poderá exercer influências desse nível nos territórios das Nações. Suas ações preservacionistas possuem natureza de fomento e são exercidas por organizações internacionais e amplamente sobre os mais diversos territórios nacionais.

O interesse dos Estados por esse auxílio internacional pode ser explicado, em parte, pelo fato que nos lembra Agustín Gordillo, de que as administrações nacionais encontram-se hoje, em matéria de finanças públicas, em endividamento sistemático ${ }^{199}$. Mas não é só isso. O título de "Patrimônio da Humanidade" também

\footnotetext{
198 Art. 22 da Convenção do Patrimônio Mundial. Unesco, Paris, 1972.

199 "La administración de numerosos servicios sociales que van desde la educación y la salud, pasan por la previsión social y avanzaron sobre la cultura, ve sus recursos progresivamente limitados". Tratado de Derecho Administrativo, tomo I, p. IV-34.
} 
"significa contar com um status internacional, prestígio e reconhecimento que é fundamental para o marketing do turismo", como bem pondera Simone Scifoni ${ }^{200}$. É o que também constata Flavio Lopes:

Nos últimos anos temos assistido, em todo o mundo, a um extraordinário aumento da procura turística relativamente aos bens inscritos na Lista do Património Mundial, rompendo-se, em alguns desses monumentos e sítios, o equilíbrio entre as condições da preservação e a capacidade de acolhimento de visitantes ${ }^{201}$.

Essa constatação reforça a importância de que as potencialidades turísticas dessas localidades sejam exploradas respeitando-se os limites de sustentabilidade destas, ou seja, buscando-se o equilíbrio entre a realização do presente e a preservação do futuro.

A adesão do Brasil à Convenção do Patrimônio Mundial foi ratificada pelo Congresso Nacional por meio do Decreto Legislativo $n^{\circ} 71$, de 30 de junho de 1977, tendo o texto da norma sido promulgado pelo Presidente da República por meio do Decreto $\mathrm{n}^{\circ} 80.978$, de 12 de dezembro de 1977.

Algumas localidades urbanas brasileiras tiveram o reconhecimento da UNESCO como Patrimônio da Humanidade. São elas, por ordem cronológica de titulação: o conjunto arquitetônico e urbanístico de Ouro Preto, em Minas Gerais (1980); o centro histórico de Olinda, em Pernambuco (1982); o centro histórico de Salvador, na Bahia (1985); o Santuário de Bom Jesus de Matosinhos, em Congonhas, Minas Gerais (1985); o conjunto urbanístico de Brasília (1987); o centro histórico de São Luis, no Maranhão (1997); o centro histórico de Diamantina, Minas Gerais (1999); e o Centro Histórico da Cidade de Goiás (2001).

200 "Patrimônio Mundial: Do ideal humanista à utopia de uma nova civilização". In Espaço e Tempo. GEOUSP. $\quad$ n. 14, São Paulo, 2003, p.06. Disponível em: www.geografia.fflch.usp.br/publicacoes/geousp/Geousp14/Geousp_14_Scifoni.htm. Acesso em: 20 nov. 2009. Nessa mesma linha, Flávio Lopes: "Presentemente, mais do que benefícios directos (financeiros e técnicos) provenientes da UNESCO, os governos de todo o mundo, ao desenvolverem esforços para incluir monumentos e sítios na Lista do Património Mundial, esperam obter prestígio e projecção internacional". Op. cit., p. 31.

${ }^{201}$ Op. cit., p. 32. 
Ainda que numa lógica distorcida, a inscrição dessas localidades na Lista do Patrimônio Mundial tem influenciado uma maior produção de atos administrativos e normativos voltados à preservação desses bens no âmbito nacional. O caso de Brasília exemplifica essa influência da UNESCO sobre as atividades administrativas e normativas nacionais, pois até meados de 1987 - ano em que a cidade foi reconhecida como Patrimônio Mundial -, seu Plano Piloto não contava com proteção jurídica específica. Esta surge por influência direta do respectivo processo de inscrição do bem na Lista do Patrimônio Mundial. ${ }^{202}$

Fala-se em distorção, em razão da aparência de que o aumento na produção de atos administrativos e normativos de preservação acabe sendo motivado mais pela busca do selo de "Patrimônio da Humanidade", do que propriamente pela convicção das autoridades de que necessário o estabelecimento de mecanismos jurídicos apropriados e ações públicas integradas e de longo prazo para a preservação eficaz dessas localidades.

Por fim, cabe anotar que a assistência internacional é prestada também sob a forma de monitoramento. Sem uma metodologia precisa, o monitoramento consiste no acompanhamento do estado de conservação dos bens inscritos na Lista do Patrimônio Mundial pelo Comitê do Patrimônio Mundial, admitindo-se que qualquer Estadoparte notifique este sobre eventuais ameaças ao Patrimônio Mundial ou descumprimento de obrigações contidas na Convenção.

Conforme aponta Fernando Fernandes da Silva, esse sistema "é bem mais do que uma rotineira inspeção periódica. Trata-se de um processo permanente de cooperação que envolve parceiros locais num contexto regional, incluindo informações e atividades de pesquisa" ${ }^{\text {203 }}$. Acrecente-se que o monitoramento internacional acaba contribuindo também para a criação de uma rotina nas atividades de conservação pelos órgãos internos dos Estados-partes, à medida que são exigidos destes relatórios periódicos.

${ }^{202}$ O Decreto federal n. 10.829 foi publicado em 14 de outubro de 1987 e o tombamento federal definitivo de Brasília foi realizado três anos mais tarde, em 1990.

${ }^{203}$ Op. Cit., p. 162. 
No que se refere às localidades urbanas brasileiras inscritas na Lista do Patrimônio Mundial, eis, a seguir, algumas recomendações já feitas pelo Comitê do Patrimônio Mundial a elas:

Com relação a Ouro Preto, o Comitê do Patrimônio Mundial já havia recomendado, em 1994, a elaboração de um plano de reabilitação integral do centro histórico, devido aos danos decorrentes do turismo ${ }^{204}$. Em 2003, motivado pelas graves destruições causadas por um incêndio a uma edificação do século XVIII, no centro histórico, o Comitê do Patrimônio Mundial requisitou do Estado brasileiro a adoção de medidas de contenção de riscos e a previsão destas medidas no plano de gestão da cidade. Requisitou também a finalização desse plano e a definição de zonas especiais para a área ${ }^{205}$. Em 2004, o Estado brasileiro demonstrou, em relatório, a delimitação e a descrição de zonas especiais, que seriam incluídas numa versão revisada do Plano Diretor de Ouro Preto de 1996.

Para o Centro Histórico de Olinda, em 1994 foram feitas recomendações de especial atenção para a formulação de uma política conciliadora do turismo e do patrimônio cultural ${ }^{206}$.

Quanto ao Centro Histórico de Salvador, o Comitê do Patrimônio Mundial reconheceu os trabalhos de restauração e revalorização da área do Pelourinho. Também promoveu a formação de um grupo de especialistas internacionais e autoridades regionais e locais, que acabaram se reunindo em 1995, em Brasília, para debater sobre as novas funções definidas para o Pelourinho e o deslocamento dos seus habitantes ${ }^{207}$.

O Santuário de Bom Jesus de Matozinhos, em Congonhas, estado de Minas Gerais, fora considerado em bom estado conservação, em 1994, embora se tenha advertido, à época, da rápida transformação da área circundante à cidade e da possibilidade de desfiguração do conjunto, no futuro. Nessa ocasião, o Comitê do

\footnotetext{
${ }^{204}$ Documento WHC 93/CONF. 002/14, Unesco, Paris, 04.02.1994, p. 21-22. Cf. também Fernando Fernandes da Silva, op.Cit, p. 165.

${ }^{205}$ Cf. Documento WHC-03/27.COM/7B, decisão 27 COM 7B.87, Unesco, Paris, 2003.

${ }^{206}$ Fernando Fernandes da Silva, op.Cit, p. 165.

${ }^{207}$ Cf. Documento WHC-93/CONF. 002/14, Unesco, Paris, 1994.
} 
Patrimônio Mundial recomendou, dentre outros pontos: a) a participação mais integrada entre autoridades nacionais de preservação e autoridades estaduais e locais; b) a implementação pela União de um plano de preservação ambiental (estudado em 1988) e, pelas autoridades locais e regionais, de um plano piloto para o povoado, em seu conjunto e nas áreas patrimoniais em particular; c) a assessoria da UNESCO sobre técnicas e normas de planejamento urbano e ambiental, assistência técnica e treinamento de pessoal; d) legislação urbana adequada para evitar maiores deteriorações paisagísticas ${ }^{208}$.

Com relação à Cidade de Goiás, em 2002, por força das destruições no Centro Histórico, causadas pelas fortes chuvas havidas na localidade, o Comitê do Patrimônio Mundial aprovou uma verba de 50 mil dólares, tendo controlado o andamento dos trabalhos de restauração da área afetada, reconhecendo, no ano seguinte, a necessidade de uma proteção urbana e ambiental integrada na localidade, para mitigar futuros impactos de fortes chuvas. ${ }^{209}$

Por fim, no que se refere ao Conjunto Urbanístico de Brasília, em 1993, o Comitê do Patrimônio Mundial recomendou a criação de um comitê interinstitucional, com representantes de setores da comunidade local favoráveis ao desenvolvimento da cidade, bem como das instituições de conservação, visando a estimular a discussão dos principais projetos de crescimento da cidade e a procura de soluções que equilibrassem a conservação e o progresso.

No plano de ações concretas, foram recomendadas, dentre outros pontos: a) a conservação dos vazios urbanos para evitar a especulação imobiliária; b) a delimitação de uma área non aedificandi para fins de manutenção de visibilidade; c) a preservação das quatro áreas do plano piloto: escala monumental, residencial, gregária e bucólica; d) a criação de espaços de encontro para usos múltiplos ${ }^{210}$.

Nos últimos anos, Brasília tem recorrentemente entrado na pauta das discussões da assembléia do Comitê do Patrimônio Mundial. Em Relatório publicado

\footnotetext{
${ }^{208}$ Fernando Fernandes da Silva, op.Cit, p. 166.

209 Documento WHC-03/27.COM/7B, decisão 27 COM 7B.86, Unesco, Paris, 2003.

${ }^{210}$ Idem, ibidem, p. 165-166.
} 
em 2000, o Comitê do Patrimônio Mundial já consignara que a cidade vinha enfrentando desafios devido ao aumento da população (então com 3 milhões de pessoas, numa cidade originalmente desenhada para 500 mil habitantes) ${ }^{211}$. Preocupações com a tutela do Conjunto Arquitetônico de Brasília continuaram sendo manifestadas nos anos seguintes. Em 2003, o Comitê recomendou o desenvolvimento e a implementação do Plano Diretor de Brasília, bem como o envolvimento continuado das autoridades, em todos os níveis, das organizações profissionais e de diferentes setores da sociedade no processo de proteção e gestão da cidade ${ }^{212}$. Em 2004, o Brasil forneceu ao Comitê do Patrimônio Mundial informações sobre o desenho e a elaboração do Plano Diretor da área protegida de Brasília, conforme recomendações feitas na sessão anterior. O Comitê recomendou então a cooperação continuada e firme entre o IPHAN e o Governo do Distrito Federal ${ }^{213}$.

A informação mais atualizada sobre monitoramentos em Brasília é de 2009, quando o Comitê do Patrimônio Mundial reconheceu progressos no desenvolvimento do plano de gestão e estimulou a finalização da delimitação de zonas especiais para a cidade. Também tomou conhecimento dos projetos em andamento, tendo requisitado a documentação técnica relativa ao Projeto da Orla, ao desenvolvimento da Vila Planalto, às soluções de transporte da W3 e mudanças no uso do solo nas superquadras, para revisão ${ }^{214}$.

Diante do exposto, nota-se a importância dada pela comunidade internacional à gestão do patrimônio cultural planejada e integrada com as principais questões sociais e econômicas das cidades analisadas, como modo de garantia de sustentabilidade destas. Exemplo disso são as preocupações comentadas acima, concernentes à conciliação adequada entre turismo e patrimônio; à garantia de discussão de projetos de crescimento da cidade; à revitalização de áreas e eventuais impactos sobre a população ali residente; à definição de zonas especiais dentro da cidade; e ao envolvimento da comunidade e do Poder Público, nos níveis nacional,

\footnotetext{
${ }^{211}$ Relatorio WHC-2000/CONF.204/21, Paris, Unesco, 2000.

${ }^{212}$ Documento WHC-03/27.COM/7B, decisão 27 COM 7B.85, Unesco, Paris, 2003.

${ }^{213}$ Documento WHC-04/28.COM/15B, decisão 28 COM 15B.108, Unesco, Paris, 2004.

${ }^{214}$ Documento WHC-09/33.COM/20, decisão 33 COM 7B.133, Unesco, Paris, 2009.
} 
estadual e municipal. Em todas essas preocupações manifestadas, é cristalino o entendimento de que a preservação do patrimônio cultural necessita ser pensada no contexto de planejamento urbano.

A designação de bens como patrimônio cultural pelos Poderes Públicos municipal ou estadual não se revela suficiente, sendo mesmo dispensável, para que aqueles bens concorram ao status de Patrimônio da Humanidade. De efeito, como condição inafastável para inscrição de bens na Lista de Patrimônio Mundial da UNESCO figura tão somente o prévio reconhecimento destes como patrimônio nacional pelo Estado-parte da Convenção de 1972. No caso brasileiro, portanto, basta o ato oficial federal de proteção.

Como desdobramento desse requisito, cogita-se aqui, em tese, a hipótese de conflito entre os interesses do Poder Público municipal, manifestados no respectivo plano urbanístico, de desenvolver e transformar a fisionomia de determinada área urbana contida no seu território (e que não conta com tutela especial municipal) e os da UNESCO, de preservar essa mesma área como Patrimônio da Humanidade. Nessa situação, perante a UNESCO, as únicas consequências jurídicas, caso o Município execute o plano urbanístico e não preserve a área, será a perda do título de Patrimônio da Humanidade para a área e, consequentemente, a eliminação de todos os auxílios técnicos e financeiros disponibilizados para conservação de bens dessa categoria.

Mas na prática, é pouco provável esse conflito, dado que, na maioria dos casos em que um determinado bem concorre ao título de Patrimônio Mundial, são os próprios Municípios quem mais se interessam em conquistar esse título, para melhor explorar economicamente o turismo no seu território.

\subsection{Mecanismos tradicionais: o tombamento e a desapropriação}

O tombamento e a desapropriação são tidos como mecanismos tradicionais de preservação do patrimônio cultural, dado serem os mais recorrentes dentre as práticas preservacionistas e há cerca de setenta anos encontrarem guarida no Direito positivo 
brasileiro para a realização desse fim. O primeiro, no Decreto-lei $\mathrm{n}^{\circ} 25$, de 30 de novembro de 1937 e o segundo, no Decreto-Lei $n^{\circ} 3.365$, de 21 de junho de $1941^{215}$. Nos termos do artigo 216, $\S 1^{\circ}$ da Constituição Federal e do artigo $2^{\circ}$ do Decreto-lei 3.365/41, todos os entes da Federação são legitimados a empregar esses dois mecanismos para a finalidade pública de preservação patrimonial.

O tombamento constitui o instrumento jurídico inaugural de preservação do patrimônio cultural no Brasil, tendo figurado por um longo período como de aplicação fundamental para o reconhecimento de um bem como integrante desse patrimônio $^{216}$. Isso porque, para que fosse assim designado, este bem deveria ser inscrito necessariamente em um dos quatro Livros do Tombo ${ }^{217}$, fosse ele público ou privado. Assim, mesmo os bens desapropriados mediante declaração de utilidade pública de preservação eram tombados - tombamento de ofício - para que se fizessem constar nos referidos Livros. Este instituto, portanto, de acordo com a ordem jurídica então vigente, tratava de promover - na medida em que ele era elemento essencial à designação do bem como patrimônio - e proteger todo o patrimônio cultural brasileiro

\footnotetext{
${ }^{215}$ Decreto-lei 3.365/41: “Art. $2^{\circ}$ Mediante declaração de utilidade pública, todos os bens poderão ser desapropriados pela União, pelos Estados, Municípios, Distrito Federal e Territórios. [...] Art. $5^{\circ}$ Consideram-se casos de utilidade pública [...] $k$ ) a preservação e conservação dos monumentos históricos e artísticos, isolados ou integrados em conjuntos urbanos ou rurais, bem como as medidas necessárias a manter-lhes e realçar-lhes os aspectos mais valiosos ou característicos e, ainda, a proteção de paisagens e locais particularmente dotados pela natureza".

${ }^{216}$ Ressalte-se que o tombamento foi instituído pensando-se num desenho de patrimônio cultural omposto somente por bens materiais. Assim dispõe o art. $1^{\circ}$, caput e $\S 2^{\circ}$ do Decreto-Lei 25/37: “Art. $1^{\circ}$ Constitui o patrimônio histórico e artístico nacional o conjunto dos bens móveis e imóveis existentes no país e cuja conservação seja de interesse público, quer por sua vinculação a fatos memoráveis da história do Brasil, quer por seu excepcional valor arqueológico ou etnográfico, bibliográfico ou artístico. [...] $\S 2^{\circ}$. Equiparam-se aos bens a que se refere o presente artigo e são também sujeitos a tombamento os monumentos naturais, bem como os sítios e paisagens que importe conservar e proteger pela feição notável com que tenham sido dotados pelo natureza ou agenciados pelo indústria humana.

${ }^{217}$ Nos termos do Decreto-Lei 25/37: “Art. $1^{\circ}[\ldots] \S 1^{\circ}$. Os bens a que se refere o presente artigo só serão considerados parte integrante do patrimônio histórico o artístico nacional, depois de inscritos separada ou agrupadamente num dos quatro Livros do Tombo, de que trata o art. $4^{\circ}$ desta lei. [...] Art. $4^{\circ}$. O Serviço do Patrimônio Histórico e Artístico Nacional possuirá quatro Livros do Tombo, nos quais serão inscritas as obras a que se refere o art. $1^{\circ}$ desta lei, a saber: 1) no Livro do Tombo Arqueológico, Etnográfico e Paisagístico, as coisas pertencentes às categorias de arte arqueológica, etnográfica, ameríndia e popular, e bem assim as mencionadas no $\S 2^{\circ}$ do citado art. $1^{\circ}$; 2) no Livro do Tombo Histórico, as coisas de interêsse histórico e as obras de arte histórica; 3) no Livro do Tombo das Belas Artes, as coisas de arte erudita, nacional ou estrangeira; 4) no Livro do Tombo das Artes Aplicadas, as obras que se incluírem na categoria das artes aplicadas, nacionais ou estrangeiras."
} 
- mediante a instituição de um regime especial de limitações administrativas fundamentado no poder de polícia.

De início, essa regra da exclusividade do tombamento para designação de todos os bens integrantes do patrimônio cultural nacional era perfeitamente compatível não somente com o modelo centralizado de gestão patrimonial praticado pelo SPHAN - este preocupado com a proteção dos monumentos excepcionais de um país então predominantemente rural $^{218}$ - como também com a natureza material desses bens. Mas ela perdeu forças com a vigência da Constituição de 1988, a partir da qual se passou a admitir que bens tais como as formas de expressão; os modos de criar, fazer e viver; as criações científicas, artísticas e tecnológicas - todos estes de natureza imaterial e, portanto, não albergados pelo regime do tombamento - pudessem, do mesmo modo que os bens materiais, ser reconhecidos oficialmente como patrimônio cultural, assim como receber a tutela especial estatal.

O constituinte de 1988 também ofereceu outros mecanismos servíveis à promoção e à proteção desse patrimônio, tais como o registro, o inventário, a vigilância, a desapropriação, etc (artigo 216, parágrafo $1^{\circ}$ ). E não destacou o tombamento dentre os instrumentos que enumerou, sugerindo, com isso, que exista certa fungibilidade entre eles, ao menos no tocante à formação do patrimônio cultural brasileiro.

A Lei 10.257/01 também se refere ao tombamento - ainda que sem quaisquer detalhamentos - como típico instrumento de política urbana (artigo $4^{\circ}$, inciso $\mathrm{V}$, alínea $d$ ). E ao lado dele, dispõe o estudo de impacto ambiental, a transferência do direito de construir e a desapropriação, dentre outros. É dizer que a adoção daquele é facultada ao Poder Público municipal, podendo este avaliar o conjunto de instrumentos urbanísticos à sua disposição na Lei e escolher os que mais convenientemente atendam aos seus problemas peculiares de preservação.

Não obstante o tombamento não seja mais meio exclusivo de formação do patrimônio cultural brasileiro, ele continua servindo a estes fins, assim como aos de

${ }^{218}$ Cf. Nestor Goulart Reis Filho, "Por uma nova política de preservação”, In OESP, 09.01.2009, p. A2. 
instituição de um regime especial de proteção ${ }^{219}$. O que mudou, portanto, foi o fato de hoje ser perfeitamente possível que estes fins sejam alcançados por outros meios, ou mesmo pela conjunção daquele com estes.

Daí se entender, com base no dispositivo constitucional acima referido, reforçado pelo teor da Lei 10.257/01, que o tombamento é ato administrativo discricionário $^{220}$, posto que à Administração Pública é conferida a faculdade de escolher, com base nos critérios de conveniência e oportunidade, uma - ou mais de uma - dentre as diferentes medidas de preservação do patrimônio cultural admitidas no Direito positivo, não necessariamente o tombamento. É que nessa matéria, permitiu o constituinte "uma proteção dinâmica e adaptável às contingências e transformações da sociedade", cabendo ao poder público avaliar a conveniência da “execução das medidas protetoras consubstanciadas no próprio conteúdo de gestão dos bens tombados"221.

É pacífico na doutrina que o ato administrativo do tombamento, quanto aos seus efeitos, tem caráter constitutivo ${ }^{222}$, dado que ele faz nascer uma situação jurídica nova, seja o bem tombado de propriedade pública ou privada. Na lição de José Afonso da Silva,

\footnotetext{
${ }^{219} \mathrm{O}$ tombamento insere-se dentre aquelas formas de salvaguarda do patrimônio qualificadas como passivas, dado que ele não tem como objetivo a restauração ou a valorização social dos monumentos, mas a simples conservação do seu estado físico. Cf. Jean Benoit Bleyon, L'urbanisme el la protección des sites..., p. 169.

${ }^{220}$ Nesse mesmo sentido, cf. Maria Sylvia Zanella Di Pietro, Direito Administrativo, p. 158. Como decisões em que se reconheceu caber ao Poder Executivo (e não ao Poder Legislativo) instituir tombamento, cf. Ação Direta de Inconstitucionalidade $\mathrm{n}^{\circ}$ 1.706/DF. STF, Relator Ministro Eros Grau, v.u., j. 9 abr. 2008; e relatório da Representação Constitucional no 1.312/RS, STF, Relator Ministro Célio Borja, j. 27 out. 1988.

${ }^{221}$ Paulo Affonso Leme Machado, Direito Ambiental Brasileiro, p. 467. Nesse sentido, cf. também Voto do Ministro Relator Octavio Gallotti no Recurso Extraordinário n. 219.292-1-MG, STF, j. 07.12.1998.

${ }^{222}$ Cf. José Afonso da Silva, Ordenação Constitucional da Cultura, p. 160. Cf. também José Cretella Jr., "Regime Jurídico do Tombamento", In Revista de Direito Administrativo, v. 112, p.56. E Carlos Augusto A. Machado, "Tombamento - Um instituto jurídico", In Adilson Abreu Dallari; Lucia Valle Figueiredo (orgs.), Temas de Direito Urbanístico 1, p. 49. Entendimento diverso pode ser induzido pela seguinte definição adotada por Hely Lopes Meirelles: "Tombamento é a declaração, pelo Poder Público, do valor histórico, artístico, paisagístico, cultural ou científico de coisas que, por essa razão, devem ser preservadas de acordo com a inscrição no próprio livro". "Tombamento e Indenização", In Revista de Direito Administrativo, v. 161, p. 1.
} 
o tombamento tanto pode incidir sobre coisas pertencentes à União, aos Estados, aos Municípios, ao Distrito Federal e às autarquias, de uso comum, especial ou dominial, assim como sobre coisas pertencentes às pessoas naturais ou às pessoas jurídicas privadas (Decreto-Lei 25, de 1937, arts. $5^{\circ}$ e $6^{\circ}$ ). Em qualquer desses casos, o tombamento é que constitui o bem tombado em patrimônio cultural [...]. Ele produz efeitos sobre a esfera jurídica dos proprietários, privados ou públicos, dos bens tombados, impondo restrições ao direito de propriedade, e cria para eles um regime jurídico especial, transformando-os em bens de interesse público (situação diversa de domínio público e de domínio privado), sujeitos a vínculos de várias espécies [...]. Tudo isso inova a situação jurídica dos bens tombados, transforma sua posição jurídica e impõe a seus proprietários condutas jurídicas, ob rem, que antes não havia, demonstrando que o tombamento, em qualquer caso, é ato constitutivo ${ }^{223}$.

Sem pretender aqui maiores aprofundamentos nas discussões doutrinárias acerca da natureza jurídica do tombamento - posto que esse assunto mereceria análise à parte - cabe apenas esclarecer que as divergências quanto à consideração do tombamento ora como espécie de limitação administrativa ${ }^{224}$, ora como servidão administrativa $^{225}$, ora como instituto sui generis ${ }^{226}$ - dentre outras considerações

223 (Grifos do autor). Ordenação Constitucional da Cultura, p. 160.

${ }^{224}$ Nesse sentido, José Afonso da Silva: "entendo que o tombamento é limitação ao caráter absoluto da propriedade, porque reduz a amplitude dos direitos do proprietário por meio de um regime jurídico especial de interesse público que impõe ao bem tombado vínculos de destinação, de imodificabilidade e limites à alienabilidade. [...] o tombamento [...] em nenhuma hipótese caracteriza servidão administrativa, simplesmente porque não gera direito real sobre a coisa tomada em favor da entidade pública". Ordenação Constitucional da Cultura, p. 160-162. Cf. também Hely Lopes Meirelles, "Patrimônio Histórico. Tombamento", In Estudos de Direito Público, v. IV, n. 2, jul-dez/85, p. 74.

${ }^{225}$ Para Celso Antonio Bandeira de Mello: "São exemplos de servidão administrativa: [...] o tombamento de bens em favor do Patrimônio Histórico", Curso de Direito Administrativo, p. 899902. Segundo Adilson Abreu Dallari, "o tombamento configura verdadeira servidão administrativa, na medida em que o Poder Público absorve uma qualidade ou um valor já existente no bem tombado, para desfrute ou proveito da coletividade. Nesse caso, o princípio da isonomia e, por decorrência dele, o princípio da distribuição das cargas públicas, obriga a coletividade beneficiária do tombamento (e representada pela administração) a reparar o dano eventualmente experimentado pelo proprietário do bem". "Tombamento", In Adilson Abreu Dallari e Lucia Valle Figueiredo (orgs.) Temas de Direito Urbanístico 2, p. 13. Cf. também Ruy Cirne Lima, "Das servidões administrativas", In Revista de Direito Público, v. 5, p. 26.

${ }^{226}$ Assim entende Maria Sylvia Zanella Di Pietro: “o tombamento tem em comum com a limitação administrativa o fato de ser imposto em benefício de interesse público; porém dela difere por individualizar o imóvel. Comparado com a servidão, o tombamento a ela se assemelha pelo fato de individualizar o bem; porém dela difere porque falta a coisa dominante, essencial para caracterizar qualquer tipo de servidão, seja de direito público ou privado. Preferimos, por isso, considerar o tombamento categoria própria, que não se enquadra nem como simples limitação administrativa, nem como servidão." Direito Administrativo, p. 159. 
verificadas na doutrina 227 - pautam-se, de um modo geral, na avaliação dos diferentes autores quanto ao grau de limitação ao direito de propriedade produzido pelo instituto (em razão de compreender obrigação de suportar e/ou individualizar o bem), assim como quanto ao caráter do direito de propriedade atingido (segundo uns, afetaria o caráter absoluto, para outros, o caráter exclusivo). Essas discussões parecem ter todas como pano de fundo uma mesma preocupação em definir doutrinariamente se o tombamento gera ou não, como efeito fático, o dever de indenizar.

Neste item, no entanto, será detida atenção apenas aos efeitos expressamente previstos no Decreto-lei $n^{\circ} 25 / 37$ - portanto inerentes ao instituto jurídico do tombamento. A análise ora proposta visa a verificar situações em que a aplicação exclusiva desse instituto não se revela adequada à realização da finalidade última de preservação e perpetuação do patrimônio cultural urbano às presentes e futuras gerações.

Assim, como efeitos do tombamento ipso iure, podem ser relacionados os referentes a:

(A) Imposição de obrigações de fazer e de não fazer aos proprietários, quais sejam:

1) Garantir o direito de preferência à União, ao Estado e ao Município nas alienações onerosas (art. 22);

2) Registrar qualquer transferência de propriedade de imóvel tombado em sua respectiva matrícula, no Registro de Imóveis competente, no prazo máximo de trinta dias $\left(\operatorname{art} .13, \S 1^{\circ}\right)$;

3) Inscrever o bem móvel tombado no Cartório de Registro de Títulos e Documentos competente sempre que ele sofrer deslocamentos e no prazo máximo de trinta dias $\left(\operatorname{art.} 13, \S 2^{\circ}\right)$;

4) Conservar e reparar o bem tombado para manutenção do seu valor cultural (art. 19);

${ }^{227}$ Cf. Lúcia Valle Figueiredo, Disciplina Urbanística da Propriedade, p. 62-63. 
5) Comunicar formalmente ao órgão de preservação: 5.1) as transferências de propriedade de imóvel tombado (art. 13, $\S 3^{\circ}$ ), 5.2) o extravio ou furto de bem móvel tombado (art. 16) e 5.3) a necessidade de obras de conservação e reparação de bem tombado quando os proprietários não dispuserem de recursos suficientes para tanto (art. $19)$;

6) Não destruir, demolir ou mutilar a coisa tombada (art. 17);

7) Não reparar, pintar ou restaurar a coisa tombada sem prévia autorização (art. 17);

8) Não promover a saída do bem tombado para fora do país (art. 14);

9) Não obstar ações de fiscalização (art. 20); e

10) Não impedir a realização de obras urgentes de conservação e reparação pelo Poder Público (art. 19, $\S 3^{\circ}$ ).

(B) Imposição de obrigações de não fazer à vizinhança dos bens tombados, consistentes em:

1) não colocar anúncios ou cartazes sem prévia autorização do órgão de preservação; e

2) não realizar construção que impeça ou reduza a visibilidade de coisa tombada sem prévia autorização do órgão de preservação.

A partir da leitura desses efeitos legalmente previstos para o tombamento, primeiramente é possível deduzir que, de um modo geral, eles exprimem uma preocupação com a conservação da integridade física do artefato material, pressupondo-se que os valores culturais estejam intrínsecos a este, ou seja, contidos em suas próprias feições físicas.

É o que revelam, mais explicitamente, as obrigações do proprietário de: conservar e reparar o bem tombado para manutenção do seu valor cultural; não destruir, demolir ou mutilar a coisa tombada; não reparar, pintar ou restaurar a 
coisa tombada sem prévia autorização; e comunicar formalmente ao órgão de preservação a indisponibilidade de recursos suficientes para obras necessárias de conservação e reparação de bem tombado.

Estas obrigações consistem em verdadeiras limitações administrativas ao exercício do direito de propriedade que se justificam, no entanto, pela necessidade de conservação da coisa em si, ou seja, da matéria que contém e traduz o valor cultural. Não resolvem, por exemplo, as necessidades de conservação e perpetuação de manifestações culturais ou mesmo de modos de vida - verdadeiros valores imateriais , presentes tradicionalmente no interior ou no ambiente da coisa tombada. Daí considerar-se ilegal o chamado tombamento de uso.

Tombamento de uso é expressão que designa uma distorção no emprego desse instituto e consiste na imposição, pelo mesmo ato de tombamento, de destinação específica aos imóveis tombados. É verdade que, pelo tombamento, poderão ser proibidos usos que não se conformarem com as necessidades de conservação das características físicas do bem tombado. Mas não é possível exigir-se uso específico desse bem pela via do tombamento, tampouco condicionar o exercício de toda e qualquer atividade pretendida à prévia aprovação do órgão de preservação.

A esse respeito, já se posicionou o Supremo Tribunal Federal por ocasião de julgamento do Recurso Extraordinário no 219.292-MG, em 7 de dezembro de 1999, nos termos da ementa de acórdão abaixo:

Tombamento de bem imóvel para limitar sua destinação à atividades artístico-culturais. Preservação a ser atendida por meio de desapropriação. Não pelo emprego da modalidade do chamado tombamento de uso. Recurso da Municipalidade do qual não se conhece, porquanto não configurada a alegada contrariedade, pelo acórdão recorrido, do disposto no art. $216, \S 1 .^{\circ}$, da Constituição. ${ }^{228}$

Tratava-se, neste caso, do tombamento de um teatro e de um cinema pela Prefeitura do Município de Belo Horizonte, cujos termos do respectivo ato

${ }^{228}$ Supremo Tribunal Federal, Recurso Extraordinário no 219.292-MG, 1. ${ }^{\mathrm{a}}$ Turma, Ministro Relator Octávio Gallotti, v.u., j. 7.12.1999. 
administrativo estabeleciam obrigações de preservação não somente das edificações, em si, mas também da própria destinação destas, exigindo-se a conservação especificamente para as atividades artístico-culturais em questão. A inadequação da medida empregada foi reconhecida pela Corte Suprema, conforme constou do voto do Ministro Relator Octávio Gallotti:

Não é, porém, contra o tombamento da edificação, ou espaço destinado a manifestações artístico-culturais que se insurge a ora recorrente, senão contra a predeterminação da modalidade de seu uso pelo Poder Público.

Ora, nada está no texto constitucional a acenar a faculdade dessa cisão ou desintegração dos atributos inerentes ao direito de propriedade, por meio de simples tombamento, em lugar da desapropriação, expressamente enumerada, entre os instrumentos de proteção do patrimônio cultural brasileiro, pelo art. $216, \S 1^{\circ}$, da Constituição. ${ }^{229}$

Na doutrina, Sonia Rabello de Castro observa com propriedade que:

\begin{abstract}
Ainda que se tombe o imóvel, não poderá a autoridade tombar o seu uso, uma vez que o uso não é objeto móvel ou imóvel. Com relação ao aspecto de uso, o que pode acontecer é que, em função da conservação do bem, ele possa ser adequado ou inadequado. Assim, se determinado imóvel acha-se tombado, sua conservação se impõe; em função disto é que se pode coibir formas de utilização da coisa que, comprovadamente, lhe causem dano, gerando sua descaracterização. Nesse caso, poder-se-ia impedir o uso danoso ao bem tombado, não para determinar um uso específico, mas para impedir o uso inadequado ${ }^{230}$.
\end{abstract}

${ }^{229}$ Idem.

${ }^{230}$ O Estado na Preservação de Bens Culturais, p. 108. Nesse mesmo sentido, cf. Sergio Andrea Ferreira: "Onde está o valor cultural: na atividade ou no imóvel? Ou na atividade somente através daquele imóvel? [...] o bem tombado é que há de ser o que se reveste do valor cultural". "O tombamento e o devido processo legal”, In Revista de Direito Administrativo, v. 208, abr-jun/1997, p. 33. 
Do exposto, depreende-se que o tombamento não é instrumento adequado para a preservação dos valores culturais presentes em edificações e espaços de manifestações artístico-culturais (artigo 216, IV, da Constituição Federal), pois nestes, os valores culturais estão contidos nos usos empregados à coisa, e não propriamente na coisa.

Do mesmo modo, quando se tratar de espaços públicos tais como coretos, jardins e áreas de reunião de grande público, o tombamento que se fizer sobre esses bens será, na prática, meramente alegórico, na medida em que os efeitos legalmente definidos para o referido instituto não são aptos a garantir adequada proteção aos valores culturais verdadeiramente em questão, que são as atividades neles desempenhadas. E quando o tombamento envolver imóvel privado, será franqueado ao proprietário o direito de questionar judicialmente a legalidade do ato administrativo respectivo - tal qual no caso mineiro exemplificado logo acima - dado que essa limitação imposta ao seu direito de uso sobre a coisa não conta com amparo legal (artigo $5^{\circ}$, inciso II, da Constituição Federal).

Uma solução possível para casos como este é, de efeito, o mecanismo da desapropriação, com fundamento no artigo, $5^{\circ}$, alíneas $h$ ) e $p$ ) do Decreto-lei $\mathrm{n}^{\circ}$ $3.365 / 41^{231}$, especialmente se se tratar de imóveis privados que historicamente abrigaram usos culturais específicos, significativos à memória dos seus usuários. Outra opção para preservação desses valores - caso se pretenda conservar a propriedade privada - é o emprego de meios promocionais de tutela, como a concessão de incentivos fiscais aos empreendedores desses espaços culturais, condicionada à conservação das atividades dessa natureza.

Uma segunda constatação a partir da análise detida dos efeitos caracterizadores do regime especial do tombamento é o modo individualizado como tomados juridicamente os bens objeto deste tipo de tutela.

\footnotetext{
231 “Art. 5ํo. Consideram-se casos de utilidade pública: [...]h) a exploração ou a conservação dos serviços públicos; [...] k) a preservação e conservação dos monumentos históricos e artísticos, isolados ou integrados em conjuntos urbanos ou rurais, bem como as medidas necessárias a manterlhes e realçar-lhes os aspectos mais valiosos ou característicos e, ainda, a proteção de paisagens e locais particularmente dotados pela natureza; $[\ldots]$ p) os demais casos previstos por leis especiais."
} 
Com efeito, predominam no texto legal obrigações atribuídas ao proprietário da coisa tombada - dentre elas, por exemplo, a de garantia do direito de preferência aos Poderes Públicos nas alienações onerosas (art. 22); e a de registro, junto à matrícula no Registro de Imóveis competente, de qualquer transferência de propriedade do imóvel tombado (art. $13, \S 1^{\circ}$ ) - corroborando a noção de que este instrumento, do modo como juridicamente instituído, limita-se a garantir unicamente a coisa tombada em sua singularidade, não levando em conta se esta encontra-se harmonicamente imbuída no seu meio ou se é usufruída pela sua vizinhança.

Essa concepção individualizada dos bens culturais, quando reforçada pelas adjetivações "excepcional valor", “feição notável” e "fatos memoráveis" - contidas no artigo $1^{\circ}$, caput e parágrafo $2^{\circ}$ do Decreto-Lei $n^{\circ} 25 / 37$ - revela a intenção de tutela legal em razão do caráter monumental daqueles, destacado das demais edificações presentes no mesmo ambiente. E ainda que exista no Decreto-lei em comento uma norma específica voltada à vizinhança de bens tombados, seu texto não traduz propriamente uma preocupação urbanística de harmonização desses bens com o meio no qual eles se inserem.

Nos termos do artigo 18 do Decreto-Lei 25/37:

Art. 18. Sem prévia autorização do Serviço do Patrimônio Histórico e Artístico Nacional, não se poderá, na vizinhança da coisa tombada, fazer construção que lhe impeça ou reduza a visibilidade, nem nela colocar anúncios ou cartazes, sob pena de ser mandada destruir a obra ou retirar o objeto, impondo-se neste caso a multa de cinquenta por cento do valor do mesmo objeto.

Pelo contrário, nesse dispositivo, o controle do entorno parece justificar-se em razão da necessidade de se destacar a coisa tombada singular do seu próprio meio, protegendo-a dos efeitos danosos que a vizinhança poderá causar ao seu excepcional valor. A coisa tombada é vista aqui mais claramente como monumento, assumindo posição hierarquicamente superior a tudo quanto exista à sua volta. $O$ valor da ambiência é, pois, adjetivo da coisa tombada, não substantivo: "é seu efeito 
qualificador que conta, em relação ao bem tombado" ${ }^{, 232}$. Por força disso, a atenção dedicada pelo Decreto-lei no 25/37 ao invólucro espacial é menor do que a dispensada ao bem protegido ${ }^{233}$.

O Decreto-lei $n^{\circ} 25 / 37$, no entanto, não oferece critérios mensuráveis para determinação do conceito de "vizinhança da coisa tombada", tampouco estabelece o grau de redução ou impedimento da "visibilidade" a partir do qual se fará necessária a fiscalização. Deixa essas definições a cargo da Administração Pública, por meio de seus órgãos de preservação, conforme aferições técnicas a serem procedidas caso a caso. $^{234}$

Há notícias de que já na década de 1950, Rodrigo Melo Franco de Andrade, amigos e colaboradores do SPHAN empenharam-se em cristalizar, junto às mais altas cortes do país, concepção mais ampliada à expressão "visibilidade", contida no dispositivo em comento, a fim de que fosse possível a aplicação do instituto do tombamento - então prontamente disponível na ordem jurídica vigente - a contextos muito mais amplos do que os originalmente imaginados ${ }^{235}$. Conforme explica Paulo Ormindo de Azevedo, "muito da literatura que se criou sobre a envoltória dos monumentos se deve à tentativa de transformar uma lei específica de proteção de bens materiais singulares em um instrumento de proteção de setores urbanos e até de cidades e municípios" ${ }^{, 236}$.

Nos Tribunais Superiores, em que há tempos se reconhece a competência judicial para apreciar os motivos do ato de tombamento ${ }^{237}$, questões relativas à

${ }^{232}$ Ulpiano Bezerra de Meneses, "A cidade como bem cultural”, In Victor Hugo Mori et alli (orgs.), Patrimônio: Atualizando o Debate, p. 44.

${ }^{233} \mathrm{Na}$ lição desse mesmo autor: "O bem tombado é que é o objeto de interesse e de proteção; se há controle do entorno, é em função do bem tombado. Portanto, valor substantivo é o do bem tombado; o entorno tem valor adjetivo". Idem, ibidem, p. 43-44.

${ }^{234}$ A Consultoria Geral da República, por ocasião de parecer acerca da construção de dois edifícios nas proximidades do Museu Imperial de Petrópolis, em 1968, já manifestou entendimento de que "não basta que a construção esteja na vizinhança da coisa tombada, é necessário que a mesma impeça ou reduza sua visibilidade". In Revista de Direito Administrativo, v. 93, p. 380.

${ }^{235}$ Paulo Ormindo de Azevedo, "Comentário 4: A cidade como obra aberta", In Victor Hugo Mori et alli (orgs.), Patrimônio: Atualizando o Debate, p. 68.

${ }^{236}$ Op. Cit, p. 68.

${ }^{237}$ Caso emblemático dessa competência é o do "Arco do Teles", julgado pelo Supremo Tribunal Federal em 19 agosto de 1943 e onde se reconheceu o valor histórico desse imóvel. Cf. Carlos 
visibilidade de bens tombados têm sido decididas muitas vezes com base nessa concepção ampla, dedicando-se uma visão de conjunto ${ }^{238}$ e 239 .

O que se deve atentar, porém, é que ainda que se adote essa concepção, nem a obrigação de não fazer contida no comentado artigo 18, tampouco todos os demais efeitos previstos pelo regime jurídico do tombamento - a maior parte relativa a obrigações dos proprietários de conservar a integridade física dos seus bens materiais tombados - são suficientes para garantir satisfatoriamente essa visão de conjunto que tanto se espera. Fica claro que o tombamento é medida importante, sim, para conter as destruições em larga escala ao patrimônio cultural urbano material, derivadas do acelerado processo de urbanização - gerador de concentrações urbanas - e dos avanços desenfreados do mercado imobiliário sobre o território da cidade. Mas não é bastante para garantir sozinha uma visão harmônica dos espaços detentores desses bens culturais e uma conservação efetiva desses bens na memória da cidade e de seus habitantes. Para tanto, faz-se necessário articular o tombamento com outros mecanismos, igualmente essenciais a essa preservação almejada, que garantam a participação popular e a conservação integrada com os moradores e utentes da cidade.

Ainda, merece menção aqui a experiência do Estado de São Paulo no que se refere ao delineamento da "vizinhança da coisa tombada".

\footnotetext{
Medeiros Silva, "Patrimônio Histórico e Artístico Nacional - Tombamento - Vizinhança Desapropriação - Registro de Imóveis - Direitos de Terceiros", In Revista de Direito Administrativo, v. 108, p. 436. Cf. também Embargos a Recurso Extraordinário n 41.279, j. 9/9/65, Supremo Tribunal Federal, Rel. Min. A. M. Vilas-Boas, in Revista de Direito Administrativo, v. 84, p. 155165, referente a construções nas proximidades do Outeiro da Glória (RJ), tombado. E Agravo em Mandado de Segurança $\mathrm{n}^{\circ}$ 10.579, Tribunal de Justiça do Rio de Janeiro, j. 02.12.1959, Rel. Des. Orlando Carlos, in Revista de Direito Administrativo, v. 74, p. 229, referente a obras nas adjacências do Museu Imperial, em Petrópolis.

${ }^{238}$ Nesse sentido, cf. voto do Ministro Presidente Djalma da Cunha Melo, na Apelação Cível n. 1.515PB, tramitada perante o Tribunal Federal de Recursos e julgada em 6/11/51, tratando da construção de ginásio esportivo nas imediações do convento de São Francisco, em João Pessoa, Estado da Paraíba: “[...] Custa crer que os Irmãos Maristas, diretores do Ginásio Pio X, prossigam insistindo em manter o aleijão, em deixar prejudicada em sua graça arquitetônica o templo já aludido, que deveriam ser os primeiros a querer ver preservado na sua visão de conjunto, na sua perspectiva, na sua austeridade, na sua beleza, na sua imponência" (grifamos). In Revista dos Tribunais, v. 222, p. 559 e ss.

${ }^{239}$ Cf. também recomendação contida no Compromisso de Salvador (de outubro de 1971), formulada por governadores de Estado, no sentido de se criar legislação complementar que amplie o conceito de visibilidade de bem tombado, a fim de se atender ao conceito de ambiência.
} 
Até 2003, vigorou disposição do Decreto $n^{\circ} 13.426 / 79$ que definia objetivamente a concepção de vizinhança por meio da adoção genérica de um raio de trezentos metros para qualquer imóvel tombado pelo CONDEPHAAT ${ }^{240}$. Esse critério era semelhante ao empregado pelo Direito francês, que estabelece, como regra geral, um raio de quinhentos metros para demarcação da área envoltória de quaisquer bens inscritos no inventário suplementar de monumentos históricos ${ }^{241}$.

Houve quem considerasse arbitrário esse dispositivo do decreto bandeirante, em razão dele definir aleatória e genericamente uma mesma dimensão de área de restrição a quaisquer bens imóveis sujeitos ao tombamento estadual ${ }^{242}$. Além disso, como constatou Ulpiano Bezerra de Meneses, se se tomasse o Município de São Paulo como exemplo, a aplicação dessa regra redundaria em "quase todo o centro urbano (centro velho e expandido, Luz e Paulista) sob controle urbanístico total do CONDEPHAAT." 243 Significava, a rigor, a necessidade de consulta prévia ao órgão preservacionista para quaisquer projetos de alteração de gabarito de imóveis situados nessa área que é a mais adensada da cidade.

O dispositivo em comento encontra-se revogado, por força do Decreto estadual $\mathrm{n}^{\circ} 48.137$, de 7 de outubro de $2003^{244}$. Mas o relato dessa dificuldade operacional de controle das áreas envoltórias dos inúmeros monumentos tombados pelo Estado somente na cidade de São Paulo serve aqui como exemplo claro de um impasse

\footnotetext{
240 “Artigo 137. Nenhuma obra poderá ser executada na área compreendendo um raio de 300 (trezentos) metros, em torno de qualquer edificação ou sítio tombado, sem que o respectivo projeto seja previamente aprovado pelo Conselho, para evitar prejuízo à visibilidade ou destaque do referido sítio ou edificação".

${ }^{241}$ Trata-se da Lei de 1913, que somente excecpcionalmente admite a adoção de metragens especiais, a serem determinadas por Decreto do Conselho de Estado. Cf. Jean-Marie Pontier, Jean-Claude Ricci e Jacques Bourdon, Droit de la culture, p. 318.

${ }^{242}$ Nesse sentido, Ulpiano Bezerra de Meneses: "Por que não 200m? Ou 400m, 500m? E por que teria a ambiência que coincidir sempre com uma área circular, quando a realidade aponta para a heterogeneidade e não a regularidade geométrica? [...] E quando a forma do bem for geometricamente irregular? E quando a inserção do bem no espaço implicar outra triangulação (isola do em espaço livre, esquina, miolo de trama, etc)? E quando houver descontinuidade espacial, embora continuidade conceitual, histórica, estilística?)". "A cidade como bem cultural", In Victor Hugo Mori et alli (orgs.), Patrimônio: Atualizando o Debate, p. 43.

243 Op. Cit, p. 43.

${ }^{244}$ Esse decreto passou a dispor que a Resolução de Tombamento é que "preverá a área sujeita a restrições de ocupação e de uso, quando estes se revelarem aptos a prejudicar a qualidade ambiental do bem sob preservação, definindo, caso a caso, as dimensões dessa área envoltória" (art. $1^{\circ}$ ).
} 
hodierno nos centros urbanos, com relação à gestão do patrimônio cultural, e que não parece ser resolvido pelas disposições deste novo Decreto, qual seja: o modo isolado de tratamento dos bens culturais urbanos pelos órgãos de preservação, favorecendo uma sobreposição de prioridades públicas diversas - muitas vezes não harmônicas entre si - para uma mesma área no território cidade.

De efeito, este modo de gestão do patrimônio definitivamente não prioriza o envolvimento dos órgãos municipais de ordenação urbana nas questões preservacionistas, tampouco a elaboração, a quatro mãos, de um plano urbanístico de conjunto para essas áreas.

Nesse mesmo contexto insere-se a questão dos chamados tombamentos de bairros, os quais, especialmente quando efetivados pelos órgãos estaduais de preservação, podem conflitar com projetos de desenvolvimento urbano desenhados pelos Municípios $^{245}$.

É verdade que, quando o ato de tombamento estadual de um bairro for superveniente aos projetos urbanísticos definidos pelo Município em áreas inseridas nesse mesmo bairro, esse conflito parece ser solucionável mais facilmente. Neste caso, aquele ato não poderá obstar a realização das obras regularmente licenciadas e já iniciadas - por uma questão de garantia a direitos adquiridos -, a menos que o Estado federado indenize os investimentos realizados pelo Poder Público municipal e desaproprie a área de interesse de preservação ${ }^{246}$. Mas quando o tombamento estadual antecede às intenções municipais de transformação deste bairro, então a questão torna-se de difícil solução.

\footnotetext{
${ }^{245}$ Cite-se como um dos inúmeros exemplos as obras do Corredor Santo Amaro - 9 de Julho, realizadas pela Prefeitura do Município de São Paulo, nos anos 80, em área compreendida no bairro dos Jardins. Pouco depois de iniciadas essas obras, o CONDEPHAAT tombou esse bairro, ato que motivou, inclusive a propositura de ação civil pública pelo Ministério Público para obstar a destruição de árvores pela Prefeitura.

246 Conforme esclarece Marcio Cammarosano, "a Administração municipal tem o direito de, no exercício de sua competência, assegurada constitucionalmente, realizar obras públicas que digam respeito ao seu peculiar interesse. Uma vez elaborado o projeto, realizada a licitação, contratada a empreiteira e iniciada a execução do projeto, ato administrativo superveniente de outra esfera governamental não tem eficácia impeditiva ou condicionadora da obra, ressalvada a regular expropriação dos direitos adquiridos dela emergentes, inclusive aquele que beneficia a empreiteira regularmente contratada". "Tombamento - Realização de Obra Pública", In Revista de Direito Público, n. 81, jan.-mar/87, p. 192.
} 
Na linha do quanto sustentado no item 3.2. deste trabalho - em que cotejadas as competências constitucionais atinentes à matéria -, não se trata, neste caso, de um conflito entre as competências comuns estabelecidas em matéria de preservação e as privativas dos Municípios, definidas para assuntos de interesse local.

O que se verifica, na realidade, é um problema de ausência de norma estadual que coordene minimamente as atividades preservacionistas em seu território. De efeito, neste caso, faltou ao Poder Público estadual implementar um plano urbanístico setorial para a defesa do patrimônio cultural urbano, contemplando planos de conjunto específicos para cada um desses bairros. Planos estes que deveriam fixar depois da audiência e do debate entre os órgãos interessados e a sociedade - as áreas a serem desenvolvidas e as áreas a serem preservadas, com vistas a harmonizar os interesses públicos em jogo ${ }^{247}$.

Outra observação relevante, relativa aos tombamentos de bairros, é que eles são instituídos, via de regra, por meio de resoluções dos órgãos de preservação, nas quais costumeiramente vêm definidas todas as restrições gerais aplicáveis ora à Administração Pública, ora aos proprietários de imóveis localizados nos bairros tombados, com vistas à preservação do traçado urbano, da vegetação e das linhas demarcatórias dos lotes desses bairros. ${ }^{248}$

Essas restrições consistem, por exemplo, com relação aos proprietários, em obrigações de: a) submeter à prévia deliberação do órgão de preservação quaisquer intervenções nos lotes situados na área tombada; e b) sujeitar novas construções aos recuos e percentual de ajardinamento mínimos, assim como aos gabaritos, taxas de ocupação e alturas máximos definidos pela resolução.

Pelo que se verifica, trata-se de restrições voltadas tipicamente a uma preservação espacial, de áreas dentro da cidade, em nada se confundindo com aquelas restrições definidas no Decreto-lei $n^{\circ}$ 25/37, destinadas à preservação pontual, de

\footnotetext{
${ }^{247}$ Nestor Goulart Reis Filho sugere que esses planos de conjunto para bairros sejam válidos por um período de 10 a 20 anos, após o que eles seriam novamente discutidos e, conforme o caso, modificados ou mantidos. "Por uma nova política de preservação", In OESP, 09.01.2009, p. A2.

${ }^{248}$ A propósito, cf. teor da Resolução no 2, de 23.01.1986 e da Resolução no 8, de 14.03.1991, ambas expedidas pela Secretaria de Cultura do Estado de São Paulo, que tombaram os bairros paulistanos dos Jardins e do Pacaembu, respectivamente. Disponível em www.cultura.sp.gov.br. Acesso em 20 fev. 2010.
} 
bens singularmente considerados. Aquelas, portanto, necessitam vir respaldadas em nova lei, não servindo-lhes para tanto o Decreto-lei $n^{\circ} 25 / 37$. Isso porquanto a resolução, na qualidade de ato normativo da Administração Pública, não tem o condão de inovar o Direito, de criar direitos e obrigações.

No que se refere ao mecanismo da desapropriação, este se justifica pela necessidade do Poder Público de aquisição de um bem para satisfação de uma utilidade pública, qual seja, no presente caso, a preservação do patrimônio cultural. O Poder Público deverá, no entanto, garantir ao expropriado prévia e justa indenização em dinheiro (artigo $5^{\circ}$, XXIV da Constituição Federal).

Esse mecanismo assume importância fundamental à efetivação dessa preservação, na medida em que se coloca como instrumento apto a dirimir aqueles casos em que a prevalência da proteção de valores culturais implica sacrifícios a direitos individuais ${ }^{249}$. Além disso, a desapropriação pode ser empregada para aquisição de imóveis que não comportam em si valores culturais, mas que se encontram no mesmo meio destes e que poderão servir à demarcação de espaços públicos de convivência com esses valores.

Com fundamento no artigo 216, parágrafo $1^{\circ}$ da Constituição Federal, a desapropriação poderá ser adotada como instrumento de preservação independentemente do tombamento, servindo inclusive à formação do patrimônio cultural brasileiro. Isso porque, como visto, o tombamento não é mais condição para esta formação e o próprio ato expropriatório que declara o bem como de utilidade pública para fins de preservação poderá assim fazê-lo, porquanto ele contém em si, expressos, os motivos da expropriação, que invariavelmente remeterão ao reconhecimento oficial de valores culturais, ainda que estes não estejam contidos propriamente no bem objeto de desapropriação.

Para além desse reconhecimento oficial, pensando-se na garantia de preservação efetiva desses bens à identidade e memória da sociedade, seriam necessárias outras medidas de promoção.

${ }^{249}$ Cf. Carlos Ari Sundfeld, Direito Administrativo Ordenador, p. 86-118. 


\subsection{O Estudo Prévio de Impacto de Vizinhança e a tutela da paisagem cultural}

O Estudo Prévio de Impacto de Vizinhança (EIV), previsto nos artigos $4^{\circ}$, VI e 36 a 38 do Estatuto da Cidade, é típico instrumento de política urbana municipal que consiste na avaliação prévia de projetos de criação ou ampliação de empreendimentos ou atividades, privados ou públicos, quanto aos potenciais impactos destes sobre a qualidade de vida dos habitantes de áreas dentro da cidade. Nos casos em que o EIV é exigido, sua elaboração configura condição para obtenção de licenças e autorizações de construção, ampliação ou funcionamento.

A ideia de um estudo prévio acerca de eventuais impactos de empreendimentos sobre o ambiente urbano não é novidade trazida pelo Estatuto da Cidade. Com efeito, desde antes da entrada em vigor desta lei, aquela já vinha sendo desenvolvida por meio de outros instrumentos jurídicos, implementados por alguns municípios com fundamento em suas competências ambientais e urbanísticas. Marcos Maurício Toba noticia que, no passado, já se chegou a implementar estudos de impacto de vizinhança com fundamento no art. 17 do Decreto federal $\mathrm{n}^{\circ}$ 99.274/1990 (que regula o EIA/RIMA) e no art. $2^{\circ}$ da Resolução CONAMA $01 / 1986^{250}$ e que em 1990 , a Lei Orgânica do Município de São Paulo já continha dispositivo prevendo relatórios de impacto de vizinhança - RIVI a projetos de significativa repercussão ambiental ou na infra-estrutura urbana ${ }^{251}$.

Mas ao padronizar minimamente o instituto do $\mathrm{EIV}^{252}$ no âmbito dos Municípios, o Estatuto da Cidade tem o mérito de estabelecer a todos eles ao menos duas regras importantes: 1) que à comunidade deve ser garantido certo grau de

\footnotetext{
${ }^{250} \mathrm{O}$ autor acrescenta que "realmente era possível uma interpretação nesses moldes, dada a amplitude abrangida pelos casos apontados na referida legislação". "Dos Instrumentos da Política Urbana: Arts. 36 a 38", In Odete Medauar; Fernando Dias Menezes de Almeida (coord.), Estatuto da Cidade..., p. 226.

${ }^{251}$ Idem, ibidem, p. 226.

${ }^{252}$ A propósito, o Município de São Paulo, em seu Plano Diretor Estratégico (Lei 13.430, de 13 de setembro de 2002), atualizou o regime do RIVI, absorvendo os preceitos gerais definidos no Estatuto da Cidade para o EIV (art. 256 e ss).
} 
envolvimento no processo de aprovação, pelo Poder Público municipal, de projetos potencialmente impactantes sobre a qualidade de vida em áreas urbanas; e 2) que o patrimônio cultural e a paisagem urbana são elementos essenciais dessa análise de impactos.

Com efeito, as normas gerais definidas pelo Estatuto da Cidade para o EIV são as seguintes:

Art. 36. Lei municipal definirá os empreendimentos e atividades privados ou públicos em área urbana que dependerão de elaboração de Estudo Prévio de Impacto de Vizinhança (EIV) para obter as licenças ou autorizações de construção, ampliação ou funcionamento a cargo do Poder Público municipal.

Art. 37. O EIV será executado de forma a contemplar os efeitos positivos e negativos do empreendimento ou atividade quanto à qualidade de vida da população residente na área e suas proximidades, incluindo a análise, no mínimo, das seguintes questões:

$$
\begin{aligned}
& \text { I - adensamento populacional; } \\
& \text { II - equipamentos urbanos comunitários; } \\
& \text { III - uso e ocupação do solo; } \\
& \text { IV - valorização imobiliária; } \\
& \text { V - geração de tráfego e demanda por transporte público; } \\
& \text { VI - ventilação e iluminação; } \\
& \text { VII - paisagem urbana e patrimônio natural e cultural. }
\end{aligned}
$$

Parágrafo único. Dar-se-á publicidade aos documentos integrantes do EIV, que ficarão disponíveis para consulta, no órgão competente do Poder Público municipal, por qualquer interessado.

Art. 38. A elaboração do EIV não substitui a elaboração e a aprovação de Estudo Prévio de Impacto Ambiental (EIA), requeridas nos termos da legislação ambiental. 
Uma primeira consideração a ser feita quanto a esse instrumento é que ele não é de adoção obrigatória pelos municípios, ou seja, fica a critério de cada um desses entes, com base nas suas competências urbanísticas, reconhecê-lo ou não como integrante de suas políticas próprias de desenvolvimento urbano local, dentre os mecanismos que lhes são sugeridos no artigo $4^{\circ}$ do Estatuto da Cidade ${ }^{253}$.

Por outro lado, se um município decidir contar com esse ferramental para auxiliar a ordenação do seu território, então deverá instituí-lo por meio de lei - e não por mero ato da Administração Pública municipal (art. 36). Com efeito, nesse caso, se estaria diante da criação de uma obrigação nova, a um grupo de indivíduos, cujo cumprimento seria, inclusive, condição para a implantação e o exercício de certos empreendimentos e atividades. Sabe-se que no âmbito das relações do Poder Público com particulares, deve prevalecer o princípio segundo o qual "ninguém será obrigado a fazer ou deixar de fazer alguma coisa senão em virtude de lei" ${ }^{254}$. Portanto, andou bem o legislador federal ao exigir, no artigo 36, que a instituição do EIV como instrumento urbanístico do Município seja feita por ato do Poder Legislativo.

Este dispositivo, no entanto, vai além, estabelecendo, também como norma geral, que é a lei municipal que deverá definir os empreendimentos que dependerão do EIV para obtenção de licenças e autorizações de funcionamento, construção e ampliação. Pode-se vislumbrar in casu uma concepção mais restrita do princípio da legalidade preconizado no artigo $5^{\circ}$, II da Constituição de 1988 , no sentido de que os contornos do campo de aplicação da obrigação nova (de realização de EIV) serão estabelecidos pela lei municipal, não havendo, nesse assunto, margem para normatividade administrativa ${ }^{255}$.

\footnotetext{
253 “Art. $4^{\circ}$. Para os fins desta Lei [regulação do uso da propriedade urbana em prol do bem coletivo, da segurança e do bem-estar dos cidadãos, bem como do equilíbrio ambiental], serão utilizados, entre outros instrumentos: [...]VI - Estudo Prévio de Impacto Ambiental (EIA) e Estudo Prévio de Impacto de Vizinhança (EIV).

${ }^{254}$ Art. 5º, II da Constituição de 1988.

${ }^{255}$ Para uma leitura sobre a evolução das concepções de princípio da legalidade, cf. Odete Medauar, $O$ Direito Administrativo em Evolução, p.144-155. Para apreensão dos debates doutrinários acerca das diversas concepções de legalidade, cf. Charles Eisenmann, "O Direito Administrativo e o Princípio da Legalidade", In Revista de Direito Administrativo, p. 47-70; Guido Zanobini, "L'attività amministrativa e la legge", In Scritti Vari di Diritto Pubblico, p. 203-217; Massimo Severo Giannini, Diritto Amministrativo, p. 83-89; José Manuel Sérvulo Correia. Legalidade e autonomia contratual nos contratos administrativos, p. 58-63 e 309-312; Domingo S. Sesin, Administração Pública.
} 
A fim de se inibir arbitrariedades e de se garantir razoável segurança jurídica nas relações dos particulares com o Poder Público, é importante que essa lei municipal empregue critérios o mais objetivos possível na definição dos empreendimentos e atividades para os quais o EIV far-se-á obrigatório ${ }^{256}$. Também, que ela cuide para definir áreas de empreendimentos que não sejam nem muito pequenas - a ponto de abranger hipóteses em que, na prática, o Estudo seria desnecessário -, nem muito grandes - de modo que pudesse esvaziar o instituto ${ }^{257}$. Nessa tarefa, deverá contemplar, no mínimo, os empreendimentos/atividades que considere capazes de gerar impactos sobre os aspectos enumerados nos incisos do artigo 37 do Estatuto da Cidade (adensamento populacional, equipamentos urbanos comunitários, uso e ocupação do solo, valorização imobiliária, tráfego e demanda por transporte público, ventilação e iluminação, paisagem urbana e patrimônio natural e cultural). Observado isso, é possível definir, por exemplo, critérios diferentes para áreas diferentes entre si, dentro do município, consideradas as peculiaridades de cada uma delas.

O Estatuto da Cidade não faz distinção entre empreendimentos residenciais e comerciais/industriais, o que dá a entender que a realização daqueles também poderá se sujeitar à prévia apresentação de EIV, caso a lei municipal assim estabeleça. Até porque a mera natureza residencial do empreendimento não é suficiente para excluir hipóteses de impactos sobre a área urbana (especialmente adensamento populacional e tráfego).

Uma vez instituído juridicamente esse mecanismo em um Município, a Administração Pública respectiva não poderá deixar de exigi-lo dos empreendimentos e atividades devidamente enquadrados na lei municipal como de elaboração obrigatória, sob pena de responsabilidade do Poder Público pelos danos causados à

Atividade regulada, discricionária e técnica..., p. 1-11; e Paulo Otero, Legalidade e Administração Pública: $O$ sentido da vinculação administrativa à juridicidade, p. 957-965.

256 Renato Cymbalista, pondera que "esses critérios podem variar conforme as características e a infra-estrutura urbana do município, e poderão basear-se, por exemplo, no impacto de tráfego gerado, sobrecarga de infraestrutura, adensamento populacional, sombreamento sobre imóveis vizinhos, poluição sonora, etc". "Estudo de Impacto de Vizinhança”, In Dicas Instituto Polis: Idéias para a ação municipal, no 192, ano 2001, p. 1. Disponível em: www.polis.org.br. Acesso em: 21 out. 2009.

257 Cf. Marcos Mauricio Toba, "Dos Instrumentos da Política Urbana: Arts. 36 a 38”, In Odete Medauar; Fernando Dias Menezes de Almeida (coord.), Estatuto da Cidade..., p. 228-229. 
vizinhança. Nesse aspecto, ressalte-se que a exigência de EIV pode incidir não somente em relação a empreendimentos ou atividades privados, como também em relação aos públicos.

A avaliação do EIV pelo Poder Público municipal deverá levar em conta as peculiaridades do empreendimento/atividade (natureza, porte, efeitos), assim como as da área considerada (caracterísicas geomorfológicas, ambientais, culturais, de infraestrutura urbana) e poderá concluir: (i) pela aprovação do empreendimento/atividade sem restrições; (ii) pela aprovação com condições ou contrapartidas específicas; ou ainda (iii) pela sua reprovação.

No Estatuto da Cidade, não existe qualquer referência a prazos para conclusão dessa avaliação do EIV, mas caberá a cada Município defini-lo. Com efeito, a estipulação desse prazo pelo Município - e, por certo, seu cumprimento efetivo por sua Administração pública - faz-se indispensável, na medida em que o EIV impõe-se como condição ao licenciamento de certos empreendimentos privados, não sendo condizente com o princípio da livre iniciativa que o empreendedor fique indefinidamente aguardando a movimentação administrativa - e assumindo os ônus dessa espera. A essa imprescindível definição de prazo para conclusão da avaliação do EIV, soma-se a necessidade de que aquele, em observância aos princípios da razoabilidade e da proporcionalidade, não seja demasiadamente longo, dado que isso poderia desestimular investimentos no município. ${ }^{258}$

Nesse aspecto, a legislação portuguesa parece estar mais avançada. $\mathrm{Na}$ intitulada Avaliação de Impacte Ambiental (AIA) - que nesse país compreende também a análise de projetos em "áreas sensíveis", tais como em zonas de proteção de imóveis classificados ${ }^{259}$ de interesse nacional, de interesse público ou de interesse municipal -, é estipulado um prazo de 25 dias, contados da recepção do relatório de consulta pública, para a comissão de avaliação proferir parecer final do sobre o

258 "A partir do momento em que o empreendedor compra o terreno, está contabilizando despesas decorrentes da não aplicação dos recursos no mercado financeiro". Renato Cymbalista, "Estudo de Impacto de Vizinhança", In Dicas Instituto Polis: Idéias para a ação municipal, $\mathrm{n}^{\circ} 192$, ano 2001, p. 2. Disponível em: www.polis.org.br. Acesso em: 21 out. 2009.

${ }^{259}$ A expressão deve ser entendida no seu sentido técnico. Classificação consiste em mecanismo jurídico de proteção do patrimônio cultural português, que em muitos aspectos se assemelha ao instituto brasileiro do tombamento. 
Estudo de Impacte Ambiental, assim como um prazo de 15 dias para que proferida a Declaração de Impacte Ambiental pelo Ministro da área do meio ambiente. ${ }^{260}$

A respeito do envolvimento da comunidade no processo de avaliação de projetos potencialmente impactantes sobre a qualidade de vida nas cidades, o artigo 37, parágrafo único do Estatuto da Cidade garantiu a publicidade dos documentos que integram o EIV, para consulta pelos interessados. É inegável a importância desse dispositivo, na medida em que ele estabelece como norma geral o dever de informação adequada do teor do EIV à população, mas por outro lado também se reconhece a timidez com que ele abordou a questão da participação da comunidade, uma vez que ritos muito mais garantidores, como o de audiência pública e o de colaboração da vizinhança na definição de contrapartidas, já eram usuais antes mesmo dessa lei, em procedimentos de avaliação de impacto urbanístico então adotados por alguns Municípios.

De qualquer forma, fica assegurado legalmente esse mínimo de envolvimento da vizinhança, nada impedindo que as leis municipais prevejam outros modos mais incisivos de participação da comunidade do que a mera permissão de acesso ao teor do EIV. Isso tudo, a fim de que seja possível consolidar um mecanismo de controle democrático sobre as interferências potencialmente nocivas à vida na cidade. Se bem explorado, o EIV poderá render bons frutos à composição de conflitos de interesses sociais presentes na cidade.

No entanto, é importante que essa avaliação dos impactos sobre a vizinhança seja sempre protagonizada pelo Poder Público. Conforme lembra Renato Cymbalista, há alguns serviços fundamentais para o funcionamento de qualquer cidade que costumam ser mal vistos pela vizinhança - como cemitérios, penitenciárias, $\operatorname{rodoviárias~}^{261}$-, podendo sofrer resistências de todas as regiões do município. Esses tipos de empreendimento são potencialmente impactantes sobre as áreas em que instalados, sendo essencial, nesses casos, que o Poder Público pondere todos os

\footnotetext{
${ }^{260}$ Cf. Fernando Alves Correia, "A Avaliação Ambiental de Planos e Programas: Um instituto de reforço da protecção do ambiente no direito do urbanismo", In Revista de Legislação e de Jurisprudência, p. 12.

261 "Estudo de Impacto de Vizinhança", In Dicas Instituto Polis: Idéias para a ação municipal, $\mathrm{n}^{\circ}$ 192, ano 2001, p. 2. Disponível em: www.polis.org.br. Acesso em: 21 out. 2009.
} 
interesses em jogo (da vizinhança e da cidade como um todo) e os efeitos desses empreendimentos sobre a área considerada, devendo resolver ele mesmo, considerada a opinião da população residente, pela adoção ou não do empreendimento no local projetado.

No que se refere à infungibilidade entre o EIA e o EIV, prevista no artigo 38 do Estatuto da Cidade, pertinente é a análise feita por Adilson Abreu Dallari acerca desses institutos:

Talvez a criação do segundo se deva ao costume ou ao preconceito no sentido de tomar a expressão 'meio ambiente' como abrangendo apenas o ambiente natural, os recursos naturais, tais como florestas, águas, montanhas etc. Na verdade, o meio ambiente a ser preservado abrange tanto os bens naturais como os bens culturais. O que deve variar, diante do caso concreto, é a forma, a metodologia, de realização do estudo, que será sempre um Estudo de Impacto Ambiental. ${ }^{262}$

Com efeito, a rigor, impactos sobre a vizinhança serão sempre impactos sobre o ambiente, este compreendendo tanto elementos naturais como construídos pelo homem. A diferença que poderia haver entre uma e outra análise seria em termos de abrangência, ou seja, quanto à amplitude do ambiente a ser considerado na avaliação, podendo-se sustentar que o segundo caso via de regra assume uma extensão maior do que o primeiro, geralmente limitado a áreas dentro do território do município. Mas ainda assim, em ambos os casos, a natureza do objeto de análise seria a mesma, qual seja, ambiental.

Isso é o que, conceitualmente, se poderia entender por "estudo de impacto ambiental" $"$. No entanto, na prática legislativa brasileira, impactos de

\footnotetext{
262 "Instrumentos da Política Urbana”, In Adilson Abreu Dallari e Sérgio Ferraz (orgs.), Estatuto da Cidade: Comentários à Lei federal no 10.257/2001, p. 84-85.

${ }^{263}$ Em sentido contrário, cf. Paulo Affonso Leme Machado: “'impacto ambiental' é qualquer alteração das propriedades físicas, químicas e biológicas do meio ambiente, causada por qualquer forma de matéria ou energia resultante das atividades humanas que, direta ou indiretamente afetam a saúde, a segurança e o bem-estar da população; as atividades sociais e econômicas; a biota; as condições estéticas e sanitárias do meio ambiente e a qualidade dos recursos ambientais", Estudos de Direito Ambiental, p. 59.
} 
empreendimentos e atividades sobre o patrimônio cultural, por exemplo, não costumam ser avaliados em sede de EIA. ${ }^{264}$ Não por impertinência temática, como visto, mas em razão da legislação ambiental ter definido toda uma estrutura organizacional e uma metodologia voltadas exclusivamente à proteção dos aspectos naturais do meio ambiente - daí a menção feita no artigo 38 de que o EIV não substituirá o EIA.

Portanto, veio em boa hora a consagração do EIV como instrumento de política urbana, à medida que se passou a contemplar a avaliação de diferentes aspectos normalmente não enfatizados pelos órgãos ambientais em suas análises e que, no entanto, do mesmo modo que os recursos naturais, estão presentes no ambiente urbano e são relevantes à qualidade de vida na cidade.

Extraído da Exposição de Motivos do projeto de lei municipal que institui o Estudo Prévio de Impacto de Vizinhança no Município de Porto Alegre, apresentado pela Câmara Municipal em 6 de abril de 2009, o trecho abaixo transcrito revela outra razão para o interesse desta municipalidade pela adoção do EIV:

Ele é, portanto, o instrumento que pode fornecer uma visão integral do empreendimento, superando os pareceres fragmentados das diferentes secretarias, que acabam por desresponsabilizar o Poder Executivo das consequências resultantes da aprovação dos empreendimentos. ${ }^{265}$

Assim, o EIV, em seu formato, contribui também para uma apreensão global e unificada do empreendimento ou atividade projetados e dos seus prováveis efeitos, sem que isso signifique dispensa de sua análise técnica pelas secretarias respectivas.

\footnotetext{
${ }^{264}$ Diversamente, o novo Código dos bens culturais e da paisagem italiano (Decreto Legislativo de 22 de janeiro de 2004, n. 42), ao tratar da Avaliação de Impacto Ambiental como medida de proteção, prevê o seguinte: "26. Valutazione di impatto ambientale. [...] 2. Qualora dall'esame del progetto effettuato a norma del comma 1 risulti che l'opera non è in alcun modo compatibile con le esigenze di protezione dei beni culturali sui quali essa è destinata ad incidere, il Ministero [per i beni e le attività culturali] si pronuncia negativamente, dandone comunicazione al Ministerio dell'ambiente e della tutela del territorio. In tal caso, la procedura di valutazione di impatto ambientale si considera conclusa negativamente."
265 PROCESSO $\mathrm{N}^{\circ} \quad 1710 / 09$ / PLL $\mathrm{N}^{\circ}$ 068/09. Disponível em: http://200.169.19.94/processo_eletronico/017102009PLL/017102009PLL_PROJETO_84763650_125 9.pdf. Acesso em: 08 dez. 2009.


Seguindo-se para a análise do artigo 37, VII do Estatuto da Cidade, as referências expressas à paisagem urbana e ao patrimônio natural e cultural nesse dispositivo evidenciam a relação intrínseca existente entre esses elementos e a qualidade de vida nas cidades, e confirmam a noção de que empreendimentos ou atividades que produzam impactos sobre aqueles afetam diretamente esta.

Entende-se também que a expressão paisagem urbana - adotada pelo legislador - comporta perfeitamente a paisagem cultural, a que já nos referimos anteriormente neste trabalho, pois toda paisagem urbana é essencialmente cultural, no sentido de ser um "sistema agregador de diferentes valores"266.

Sendo assim, os termos do inciso VII desse dispositivo permitem uma compreensão adequada do patrimônio cultural urbano no seu aspecto ambiental, ou seja, enquanto paisagem integradora e sintetizadora de valores culturais materiais e imateriais, interagentes entre si e sujeitos a contínuas transformações, dada a essência dinâmica das cidades.

E o instituto do EIV, na medida em que se propõe a analisar potenciais impactos sobre a paisagem cultural, torna-se importante mecanismo de controle para que as inevitáveis alterações da cidade - nas suas funções e utilização - ocorram com as devidas precauções, ou seja, sem que se perca a essência dos valores culturais presentes no ambiente urbano, referenciais à memória e à identidade dos seus habitantes.

Conforme observa Paulo Ormindo de Azevedo,

o valor do casario de nossas cidades e bairros tombados está, ao nosso ver, menos nas suas paredes de adobe ou pau-a-pique, que nas relações espaciais que viabilizam formas de sociabilidade tradicionais extremamente ricas. [...] Sem o controle do tráfego e do

${ }^{266}$ Rafael Winter Ribeiro, Paisagem cultural e patrimônio, p. 110. 
uso do solo, seus elementos qualificadores - chafarizes, capelas, cruzeiros, passos da paixão e pontes - perdem o seu significado. ${ }^{267}$

O EIV, portanto, revela-se uma interessante opção de mecanismo de tutela do patrimônio cultural brasileiro, especialmente nesses casos em que os valores culturais que se pretende tutelar não se referem exatamente a elementos técnicos de monumentos isolados, mas especialmente a formas de interação dos habitantes e usuários da cidade com estes.

Isso porque, muito mais do que vedações passivas, a adoção do EIV pelos Municípios pode oferecer, a partir da análise de cada caso, sugestões de alterações no projeto original do empreendimento ou atividade, bem como de contrapartidas das mais diversas ordens (tais como não isolamento de equipamentos públicos, absorção de tráfego, etc.) de modo a garantir-se o necessário resguardo desses valores culturais referenciais à população.

Nesse contexto, é indiscutível a importância que assumem os habitantes locais, como demonstra Ulpiano Bezerra de Meneses:

[...] a cidade culturalmente qualificada é boa para ser conhecida (pelo habitante, pelo turista, pelo que tem aí negócios a tratar, pelo técnico, etc.), boa para ser contemplada, esteticamente fruída, analisada, apropriada pela memória, consumida afetiva e identitariamente, mas também, e acima de tudo, é boa para ser praticada, na plenitude de seu potencial. Em outras palavras, para ser culturalmente qualificada como cidade, ela precisa ser boa como cidade, precisa de condições de viabilidade econômica, infraestrutura, políticas adequadas de habitação, transporte, saúde, educação, etc.

Nessa ordem de idéias, o principal sujeito de cultura é o habitante local. A palavra 'habitante' vem do latim habeo, que quer dizer 'ter', manter uma relação constante com algo; o sufixo 'it' (habito) aprofunda e reitera esta relação. Hábito, habitar, portanto, expressam

267 "Comentário 4: A cidade como obra aberta". In Victor Hugo Mori et alli (orgs.) Patrimônio: Atualizando o debate, p. 65. Cf. também Georges Louis Hage Humbert, "O estudo do impacto de vizinhança como instrumento de proteção ao meio ambiente cultural”, In Forum de Direito Urbano e Ambiental, p. 3325-3326. 
um grau superior e constante de apropriação. Essa relação contínua, permanente, cotidiana, demorada e que o tempo adensa é que cria as condições mais favoráveis para a fruição do patrimônio ambiental urbano. ${ }^{268}$

Daí a importância da colaboração da comunidade local - por meio de audiências públicas ou por outros meios - no processo de avaliação do EIV pelo Poder Público municipal: primeiramente porque a ela é que os valores culturais da cidade servem primordialmente como referência e, em segundo lugar, porque é ela quem melhor contribuirá para a defesa e conservação desses valores.

E porquanto a paisagem urbana e o patrimônio cultural constituem elementos essenciais de análise do EIV, não parece demasiado concluir que, nos processos de avaliação de EIVs, os órgãos ou entidades municipais de preservação - ou, na ausência destes, as secretarias de cultura - deverão ser ouvidos, assim como convidados a participar da formulação de condições ou contrapartidas aos empreendimentos e atividades relativamente impactantes sobre o patrimônio cultural urbano.

Enfim, do quanto se apresentou até aqui, verifica-se que o EIV constitui interessante mecanismo de controle da expansão de áreas urbanas, servindo inclusive à tutela do patrimônio cultural urbano. Tem o mérito de garantir aos habitantes locais - estes essenciais à conservação e perpetuação dos valores culturais presentes na cidade -, no mínimo, o acesso à integralidade dos documentos que compõem o EIV.

É, no entanto, um mecanismo a priori limitado ao âmbito e à competência dos Municípios, como típico instrumento de suas políticas urbanas (art. 37 do Estatuto da Cidade), ao passo que a tutela do patrimônio cultural brasileiro cabe conjuntamente a todos os entes federados.

É exatamente em razão do tratamento dispensado ao patrimônio cultural pela Constituição de 1988 (art. 216) - atribuindo-lhe um caráter de legado brasileiro às futuras gerações - e do poder-dever constitucional dos Poderes Públicos, nos três

268 “A cidade como bem cultural...”, In Victor Hugo Mori et alli (orgs.), Patrimônio: Atualizando o debate, p. 39. 
níveis da Federação, de mútua cooperação na gestão do patrimônio cultural brasileiro, que não seria exagerado defender que União e Estados-membros respectivos, por meio de seus órgãos de preservação, deverão, sempre que necessário, assistir os Municípios nas avaliações de EIVs que envolvam potenciais impactos sobre o patrimônio cultural urbano, seja essa colaboração técnica - por meio de pareceres, de disponibilização de pessoal especializado para averiguações e sugestões de alterações ou contrapartidas - ou financeira - por meio de repasse de recursos.

E não há que se falar que, neste caso, o patrimônio seria assunto de interesse local, portanto de responsabilidade exclusiva do Município, pois conforme já exposto neste trabalho, os valores referenciais à memória e à identidade dos diferentes grupos que formam a sociedade brasileira são reconhecidos constitucionalmente como interessantes à Federação como um todo, posto que relevantes à cultura e ao bemestar nacional, conforme indicam o artigo 23, III, IV e parágrafo único, assim como o artigo 216 da Constituição de 1988.

\subsection{Transferência do direito de construir}

Outro instituto previsto no Estatuto da Cidade como instrumento de política urbana disponível aos municípios é a transferência do direito de construir. Esse instituto interessa sobremaneira o tema da preservação do patrimônio cultural urbano, na medida em que ele pode servir para garantir a não-edificação em imóveis urbanos dotados de interesse cultural, muitas vezes situados em áreas de crescente valorização imobiliária e verticalização.

Nos termos do artigo 35 dessa lei:

Art. 35. Lei municipal, baseada no plano diretor, poderá autorizar o proprietário de imóvel urbano, privado ou público, a exercer em outro local, ou alienar, mediante escritura pública, o direito de construir previsto no plano diretor ou em legislação urbanística dele 
decorrente, quando o referido imóvel for considerado necessário para fins de:

I - implantação de equipamentos urbanos e comunitários;

II - preservação, quando o imóvel for considerado de interesse histórico, ambiental, paisagístico, social ou cultural;

III - servir a programas de regularização fundiária, urbanização de áreas ocupadas por população de baixa renda e habitação de interesse social.

$\S 1^{\circ}$. A mesma faculdade poderá ser concedida ao proprietário que doar ao Poder Público seu imóvel, ou parte dele, para os fins previstos nos incisos I a III do caput.

$\S 2^{\circ}$. A lei municipal referida no caput estabelecerá as condições relativas à aplicação da transferência do direito de construir.

A transferência do direito de construir, assim como a outorga onerosa do direito de construir, prevista nos artigos 28, 30 e 31 do Estatuto da Cidade, baseiamse na concepção de que o direito de propriedade compreende uma parcela do direito de construir, até um limite objetivamente estabelecido pela lei, para além do qual se faz necessária uma outorga específica do Poder Público para seu exercício ${ }^{269}$.

Essa concepção adotada hoje pela lei federal tem como marco histórico, no Brasil, os amplos debates doutrinários ocorridos notadamente na década de 1970, envolvendo o instituto do solo criado e sua constitucionalidade como instrumento de intervenção urbanística, ocasião em que também se discutiu a transferência do direito de construir ${ }^{270}$.

\footnotetext{
${ }^{269}$ Para Márcia Walquiria Batista dos Santos, "mesmo o direito de construir sendo inerente ao direito de propriedade, assim o é com reservas, na medida em que o Estado assumiu uma postura não mais indiferente ao seu papel ordenador e garantidor (pelo menos nas questões urbanísticas)". "Instrumentos da Política Urbana (arts. 28 a 35)", In Odete Medauar; Fernando Dias Menezes de Almeida (coord.), Estatuto da Cidade..., p. 209. Na doutrina francesa, em defesa de que o espaço privado deveria ser limitado em volume de construção, cf. Jean-Paul Gilli, Redéfinir le droit de propriété, p. 101-102.

${ }^{270}$ Para conhecimento do teor dessas discussões, cf. O Solo Criado/Carta de Embu, CEPAM Fundação Prefeito Faria Lima, 1977, p. 43-123. Cf. também Eros Grau, Direito Urbano, 54-84. Para uma síntese das principais ideias desenvolvidas em países europeus sobre o direito de construir e sua relação com o direito de propriedade, cf. Fernando Alves Correia, O plano urbanístico e o princípio da legalidade, p. 607 e ss.
} 
Ela é intermediária de outras duas concepções também defendidas na doutrina: uma, mais civilista, que considera que o direito de propriedade compreende o exercício do direito de construir em sua plenitude, como decorrência direta dos atributos de gozo e fruição daquele, sobretudo em se tratando de propriedade urbana, cuja destinação natural seria a edificação ${ }^{271}$. E outra, mais publicista, que entende o direito de construir como direito autônomo, de titularidade coletiva, portanto externo ao domínio da coisa e somente exercido pelo particular mediante outorga do Poder Público. $^{272}$

Uma vez concebendo que parte do direito de construir vem inserida no direito de propriedade, o Estatuto da Cidade estabeleceu, então, que os contornos daquele deverão ser definidos pelo plano diretor - enquanto instrumento norteador de toda a política urbana do município -, a partir da fixação de um coeficiente de aproveitamento básico, o qual poderá ser "único para toda a zona urbana ou diferenciado para áreas específicas dentro da zona urbana" (artigo 28, parágrafo $2^{\circ}$ ). Por coeficiente de aproveitamento, entendeu a lei federal "a relação entre a área edificável e a área do terreno" (artigo 28 , parágrafo $1^{\circ}$ ).

Portanto, de acordo com a lei geral, o coeficiente de aproveitamente básico é o índice definidor da porção de direito de construir que constitui direito subjetivo do titular do domínio. A partir da perfeita apreensão desse direito subjetivo do proprietário é que se torna possível, nas hipóteses admitidas em lei, a aplicação do instituto da transferência do direito de construir ora em análise.

Conforme previsto no artigo 35, nos casos de imóveis urbanos considerados necessários a determinadas finalidades públicas, a lei municipal poderá autorizar que seus respectivos proprietários alienem ou exerçam em outro local da cidade a parcela de direito de construir a que ordinariamente fariam jus, não fosse a afetação do imóvel. O mesmo se aplica aos proprietários que doarem seus imóveis ao poder público municipal para realização desses fins (artigo 35, parágrafo $1^{\circ}$ ).

271 Cf. Yara Darcy Police Monteiro e Egle Monteiro da Silveira, "Transferência do Direito de Construir", In Adilson Abreu Dallari e Sérgio Ferraz (coord.), Estatuto da Cidade..., p. 297.

${ }^{272}$ Cf. Floriano de Azevedo Marques Neto, "Outorga onerosa do direito de construir (solo criado)", In Adilson Abreu Dallari e Sérgio Ferraz (coord.), Estatuto da Cidade..., p. 224-228. 
Yara Darcy Police Monteiro e Egle Monteiro da Silveira enumeram como elementos essenciais desse instituto:

1) doação ou afetação de determinado imóvel urbano a uma das finalidades públicas previstas nos incisos I a III do art. 35;

2) a vinculação do imóvel ao atendimento dos fins públicos enunciados deverá ser de proporções a impedir, ao menos parcialmente, sua utilização funcional, ou seja, a possibilidade de edificação segundo os índices e potenciais de construção previstos no plano diretor;

3) a autorização, veiculada por lei municipal, ao proprietário que teve seu direito de construir amesquinhado, ou que tenha doado seu imóvel, para exercer em outro local o correspondente direito de construir previsto no plano diretor, para efeitos de reparação ou compensação. Tal compensação poderá ser concretizada também por meio de alienação, mediante escritura pública, do direito de construir;

4) o plano diretor, devidamente aprovado pela Câmara de Vereadores, é condição para que o Município possa contemplar a transferência do direito de construir na lei local, posto que do plano defluem os parâmetros conformadores desse instrumento urbanístico. $^{273}$

Dessa análise procedida pelas autoras, sublinhe-se o caráter compensatório do instituto em relação ao proprietário, ou seja, restitutivo de um reconhecido direito subjetivo à edificação, dele subtraído em razão de interesse público ${ }^{274}$. Ressalte-se também a exigência legal de plano diretor como requisito para a adoção do instituto pelo Poder Público municipal, a sugerir uma preocupação do legislador federal de que os municípios tenham seu território minimamente organizado, com definição das zonas da cidade aptas a comportar esses acréscimos construtivos.

\footnotetext{
273 (Grifamos). "Transferência do Direito de Construir", In Adilson Abreu Dallari e Sérgio Ferraz (coord.), Estatuto da Cidade..., p. 291-292.

${ }^{274}$ Jean-Paul Gilli propõe a indenização em todos os casos em que as regras jurídicas urbanísticas proibam ou interditem o proprietário de utilizar o seu espaço privado, impondo-lhe um gravame anormal. Redéfinir le droit de propriété, p. 108 e ss.
} 
À parte a redundância do inciso II do artigo 35, posto que a mera referência aos gêneros "social e cultural" bastariam para compreender as espécies "histórico", "ambiental" e "paisagístico", o legislador federal, ao contemplar essas hipóteses como autorizadoras de transferência do direito de construir, consagrou no ordenamento jurídico pátrio um novo mecanismo de preservação do patrimônio cultural, dando fôlego aos municípios para também o adotarem em reforço ao instituto do tombamento.

De efeito, em benefício do interesse público de preservação do patrimônio cultural urbano, a transferência do direito de construir confere garantia jurídica de conservação das dimensões originais de imóveis tombados localizados em áreas urbanas cujos coeficientes de aproveitamento básico admitiriam edificar em dimensões superiores às daqueles. Como contrapartida, essa medida possibilita que os proprietários desses imóveis tombados aproveitem economicamente - seja em outras áreas, seja alienando - o direito de construir remanescente dos seus domínios, isto é, aquela parcela de direito de edificar a qual ele ficou impossibilitado de exercer em seu imóvel em razão do gravame imposto pelo tombamento.

Há de se ter em mente, no entanto, que esse modelo teórico alcançará os objetivos de preservação, na prática, na medida em que a ideia de aquisição de potenciais construtivos se mantiver sempre atraente para o mercado. É certo que uma série de fatores, das mais diversas ordens, podem influenciar o interesse do mercado por esses potenciais. Mas há uma condição mínima, inafastável, para o sucesso da medida, consistente na garantia de que as normas urbanísticas definidoras dos coeficientes de aproveitamento não sejam alteradas no futuro. Como reforça Eros Grau:

[...] a adoção do instituto da transferência do direito de construir apenas é viável quando não exista a possibilidade da mudança da legislação que fixa o coeficiente de aproveitamento. Se houver essa possibilidade, provavelmente, ninguém se interessará em adquirir direitos de criar solo a outros proprietários de imóvel. Por esta razão é que, sistematicamente, a idéia da transferência do direito de construir vem sendo considerada atrelada à noção de solo criado que, por sua vez, implica a adoção de um coeficiente único, inalterável. 
Diz-se que a transferência do direito de construir agiria "em reforço" ao tombamento, tendo em vista o caráter complementar daquela em relação a outras medidas preservacionistas. ${ }^{275}$

Nesse sentido, ressalte-se, em primeiro lugar, que a lei federal exige, como condição própria da aplicação da transferência do direito de construir, que o imóvel tenha sido reconhecido como de interesse público ${ }^{276}$. Daí já ser possível concluir que tal imóvel deve submeter-se previamente ao menos a algum tipo de identificação oficial como detentor de valor cultural.

Em segundo lugar, essa transferência, enquanto medida de preservação, limita-se a impedir que imóvel de valor cultural seja destruído ou tenha suas dimensões originais descaracterizadas pelo proprietário para aproveitamento integral do potencial construtivo admitido para a área urbana. De modo que quaisquer outras ações específicas, igualmente necessárias à completa satisfação do interesse público de preservação - como por exemplo, as que impliquem encargo extraordinário de obrigações positivas para o proprietário -, dependerão da adoção concomitante de outros mecanismos.

A lei federal não ofereceu maiores detalhamentos quanto ao modo de aplicação do instituto, reconhecendo a autonomia dos municípios para legislarem a esse respeito, conforme as peculiaridades de suas respectivas localidades (Artigo 35, parágrafo $2^{\circ}$ ).

No Brasil, o município de Curitiba assumiu posição pioneira nessa matéria ao instituir, já no início da década de 1980 - portanto, muito antes do Estatuto da Cidade -, a transferência do potencial construtivo para o seu território. Então regido pela Lei municipal $n^{\circ} 6.337 / 82$, este instrumento foi previsto como mecanismo para proteção

\footnotetext{
${ }^{275}$ John Costonis, por ocasião em que defendia esse mecanismo no Plano de Chicago: "Nor is the Plan offered as a substitute for conventional non-compensatory preservation programs. On the contrary, most cities will probably prefer to employ the Plan as a complement to these programs, utilizing it only when constitutional or practical obstacles demand recourse to a compensatory alternative." Space Adrift: Saving urban landmarks through the Chicago Plan, p. xvii.

276 “Art. 35. Lei municipal [...] poderá autorizar [...] II - [...] quando o imóvel for considerado de interesse histórico, ambiental, paisagístico, social ou cultural".
} 
de imóveis históricos classificados oficialmente como Unidades de Interesse de Preservação (UIP).

A partir de então, a produção de leis municipais contemplando esse instituto intensificou-se - não obstante ainda prevalecesse, nesse tempo, na doutrina e na jurisprudência, o entendimento de que leis com esse conteúdo seriam de competência da União, alegadamente em razão de tratar-se de direito de propriedade, matéria afeta ao Direito Civil (artigo 22, I da Constituição Federal). Cite-se como exemplo os casos de Florianópolis (Lei no 3.338/89); Belém (Plano Diretor de 1993); Belo Horizonte (Plano Diretor de 1996); Campinas (Lei complementar $n^{\circ}$ 04/96) e Porto Alegre (Lei complementar $\left.\mathrm{n}^{\circ} 435 / 99\right)$.

Nos Estados Unidos, no início dos anos 70, quando então se elaboravam os termos do Plano Urbanístico de Chicago, um estudo bastante detalhado sobre o tema foi desenvolvido por John J. Costonis, enfatizando a utilidade desse instituto "transfer of development rights" (TDR) - especialmente para os fins de preservação dos monumentos inseridos em áreas urbanas adensadas da cidade e extremamente valorizadas pelo mercado imobiliário. ${ }^{277}$

Esse estudo procurava demonstrar que o mecanismo do TDR era capaz de assegurar a preservação desses monumentos com um custo mínimo para os seus proprietários, bem como para a cidade. Como ponto de partida para as propostas depois apresentadas, adotou-se que:

1) Os monumentos urbanos possuem tipicamente dimensões muito menores que as admitidas pelo zoneamento vigente para a área e mesmo que as edificações ordinárias ali presentes;

2) A maior parte desses monumentos pode ser gerida de maneira lucrativa, sendo que a vulnerabilidade destes no mercado imobiliário decorre, na verdade, da desproporção que há entre o valor de seus terrenos e o reduzido espaço que eles ocupam nestes;

\footnotetext{
${ }^{277}$ John J. Costonis. Space Adrift: Saving urban landmarks through the Chicago Plan, University of Illinois Press, 1974, 207p.
} 
3) Esses monumentos encontram-se com frequência concentrados em uma ou mais áreas razoavelmente adensadas da cidade, geralmente no seu centro.

4) serviços públicos e facilidades são tipicamente mais abundantes em áreas centrais, permitindo que essas áreas absorvam grande número de pessoas com maior eficiência que em outras áreas da cidade. ${ }^{278}$

A partir daí, o autor formulou o programa de TDR da seguinte maneira: ${ }^{279}$

Preliminarmente, deveria haver a demarcação oficial de uma ou mais áreas dentro da cidade onde pudessem ser exercidos os direitos transferidos ("TDR districts"). Essas áreas poderiam coincidir com aquela onde localizados os monumentos ou ser outras, onde existisse demanda de mercado por novas construções.

Quando da inventariação do monumento, ou a qualquer tempo depois desta, o proprietário seria legitimado a transferir seus direitos de construir não utilizados para outros lotes dentro dos "TDR districts", além de ser contemplado com a redução do imposto predial proporcional ao decréscimo que se verificasse no valor da propriedade em razão da limitação de construir.

Em contrapartida, incidiria sobre esses imóveis uma "preservation restriction" que proibiria seus proprietários presentes e futuros de voltar a construir naqueles, bem como os obrigaria a mantê-los em consonância com as boas práticas de gestão de edifícios. Essas medidas, para o autor, reduziriam interesses especulativos nos terrenos desses monumentos urbanos.

A adesão a esse programa de TDR pelos proprietários, de todo modo, seria facultativa e a recusa por parte destes implicaria a desapropriação do imóvel. Nota-se aqui o reconhecimento de que a preservação de monumentos urbanos nas áreas adensadas da cidade de Chicago constituiria, invariavelmente, um gravame sobre o

\footnotetext{
${ }^{278}$ Idem, Ibidem, synopsis, p. 1.

${ }^{279}$ Idem, Ibidem, synopsis, p. 1-2.
} 
direito de propriedade, o qual deveria ser devidamente compensado, fosse pelo mecanismo do TDR, fosse pela desapropriação.

As despesas com a aquisição desses imóveis desapropriados, assim como outras necessárias à operacionalização do programa seriam pagas por um banco (“development rights bank"), administrado pelas autoridades públicas, basicamente com as receitas provenientes da venda dos direitos de construir de monumentos públicos e desapropriados, e dos direitos de construir de monumentos privados, doados por seus proprietários.

Enfim, a importância desse estudo desenvolvido nos Estados Unidos, no bojo das discussões sobre o Plano de Chicago, em 1973, revela-se na iniciativa de se estruturar todo um programa de sustentabilidade dos monumentos históricos situados em áreas valorizadas da cidade. Visando a conservá-los integrados a esta, adotou-se como primado básico desse sistema a necessidade de que esses monumentos mantivessem seus usos privados, servindo às necessidades comerciais da cidade, em detrimento de eventuais usos que acabassem por comprometer sua verdadeira fruição pelos habitantes desta.

\subsection{Os planos urbanísticos}

Sabe-se que a preservação do patrimônio cultural urbano visa a garantir às presentes e futuras gerações de indivíduos o pleno gozo dos valores culturais materiais e imateriais contidos no ambiente citadino e referenciais às suas identidades e memórias. E que o Estado, ao assim proceder, busca proporcionar a estes indivíduos, em última análise, o alcance de níveis elevados de bem-estar e de qualidade de vida.

Do mesmo modo, é certo que toda política de desenvolvimento urbano traduz um projeto estatal de racionalização urbana que tem por objetivo "ordenar o pleno desenvolvimento das funções sociais da cidade e garantir o bem-estar de seus habitantes" (artigo 182 da Constituição Federal de 1988). 
Assim é que, tendo em vista esses objetivos comuns, a tutela estatal dos bens culturais presentes na cidade deverá ser conduzida de forma planejada, no mesmo contexto em que definidas as normas e ações de ordenação do território ${ }^{280}$.

O planejamento, genericamente considerado, consiste em "um processo técnico instrumentado para transformar a realidade existente no sentido de objetivos previamente estabelecidos" 281 . Segundo o ordenamento pátrio, a adoção do planejamento para fins de desenvolvimento nacional não é mera faculdade conferida ao Poder Público, mas verdadeira imposição jurídica, fundamentada nos artigos 21, IX ("Compete à União [...] elaborar e executar planos nacionais e regionais de ordenação do território e de desenvolvimento econômico e social"); 174 , caput e $\S 1^{\circ}$ ("Como agente normativo e regulador da atividade econômica, o Estado exercerá, na forma da lei, as funções de fiscalização, incentivo e planejamento [...]" e "a lei estabelecerá as diretrizes e bases do planejamento do desenvolvimento nacional equilibrado, o qual incorporará e compatibilizará os planos nacionais e regionais de desenvolvimento"); 30, VIII ("Compete aos Municípios: [...] promover, no que couber, adequado ordenamento territorial, mediante planejamento e controle do uso, do parcelamento e da ocupação do solo urbano") e 182, $\S 1^{\circ}$ da Constituição Federal (“O plano diretor, aprovado pela Câmara Municipal [...] é o instrumento básico da política de desenvolvimento e de expansão urbana”).

Portanto, o processo de planejamento constitui mecanismo jurídico no qual deverão necessariamente estar pautadas as ações da Administração Pública brasileira para a realização de transformações sociais e econômicas positivas sobre a realidade brasileira. $\mathrm{Na}$ ordem urbanística, por exemplo, o planejamento é pressuposto de qualquer ação do Poder Público.

Alguns dos dispositivos apontados acima, somados ao artigo 48, IV da Constituição de 1988 (que atribui ao Congresso Nacional a incumbência de dispor

\footnotetext{
${ }^{280}$ Flavio Lopes reconhece, nesse mesmo sentido, que: "a salvaguarda das cidades e bairros históricos deve, para ser eficaz, integrar-se numa política coerente de desenvolvimento econômico e social e ser tomada em consideração em todos os níveis do planeamento territorial e do urbanismo". "Evolução do pensamento contemporâneo através da leitura de normas internacionais", In Flavio Lopes; Miguel Brito Correia (orgs.) Património arquitectónico e arqueológico: Cartas, Recomendações e Convenções Internacionais, p. 31.

281 (grifo do autor). José Afonso da Silva, Direito Urbanístico Brasileiro, p. 95.
} 
sobre planos e programas nacionais, regionais e setoriais de desenvolvimento), também conferem expressamente aos planos - instrumentos desse processo de planejamento - a natureza de lei. Essa determinação específica do Direito brasileiro de que os planos sejam aprovados em lei, assumindo, portanto, uma dimensão jurídica - serve às necessidades de conformação e limitação do exercício de direitos individuais dos administrados, com vistas à consecução dos objetivos públicos de desenvolvimento e bem-estar previamente definidos.

No caso especial dos planos urbanísticos, segundo destaca José Afonso da Silva, estes "importam inovação de grande profundidade no ordenamento jurídico, [...] impondo obrigações e constrangimentos e gerando direitos que, no sistema brasileiro, somente se compreendem mediante lei" ${ }^{282}$.

Por sua vez, o processo de planejamento urbanístico, na medida em que se consubstancia em planos devidamente instituídos na ordem jurídica, não se resume mais a um simples fenômeno técnico, mas a um verdadeiro processo coeso e dinâmico de criação de normas jurídicas, composto por uma fase preparatória relativa a planos gerais normativos - e outra vinculante - referente a planos de atuação concreta, de natureza executiva. ${ }^{283}$ De modo que as leis que aprovam os planos urbanísticos contém, em si, todo um conjunto articulado de diretrizes normativas e de regras concretas dotadas de eficácia jurídica e capazes de transformar e inovar a situação jurídica até então existente. ${ }^{284}$

É pacífico que a experiência brasileira em planejamento urbanístico ainda não surtiu efeitos satisfatórios. ${ }^{285}$ No âmbito dos Municípios, poucos foram os que estabeleceram, na prática, um processo de planejamento permanente, não obstante sempre se tenha atribuído competência a esses entes para elaborar e executar planos urbanísticos. Essa descontinuidade nos planejamentos de âmbito municipal deve-se a

\footnotetext{
${ }^{282}$ Idem, Ibidem, p. 98.

283 (grifos do autor). Op. Cit, p. 95.

${ }^{284}$ Idem, Ibidem, p. 98.

285 José Afonso da Silva, op. Cit., p. 101. Para Flávio Villaça, "Exceção feita ao zoneamento [...], o planejamento urbano no Brasil tem sido fundamentalmente discurso". Em outro trecho: "O planejamento urbano [...] não tem sido no Brasil [...] uma atividade orientadora ou guia da ação do Estado, no nível local, metropolitano ou em qualquer outro". "Uma contribuição para a história do planejamento urbano no Brasil", In Csaba Déak; Sueli Ramos Schiffer (orgs.), O processo de urbanização no Brasil, p. 222-223.
} 
uma série de fatores, mas especialmente à carência de recursos técnicos, financeiros e humanos, além de, como avalia José Afonso da Silva, “certo temor do Prefeito e da Câmara de que o processo de planejamento substitua sua capacidade de decisão política e de comando administrativo" ${ }^{\text {286 }}$.

Ao mesmo tempo, já se comentou neste trabalho que o planejamento urbanístico local, mesmo que permanente, seria insuficiente para resolver problemas urbanos contemporâneos que muitas vezes transcendem os limites municipais ${ }^{287}$.

Nesse contexto, foi ganhando forças a preocupação em institucionalizar um sistema de planejamento urbanístico estrutural voltado à realização de uma política urbana global, cujo objeto compreenderia tanto o desenvolvimento adequado da rede urbana - tomada nos níveis nacional, regional e estadual (planejamento interurbano)-, quanto o desenvolvimento do território urbano municipal (planejamento intraurbano $^{288}$.

Esse sistema de planejamento urbanístico estrutural, já preconizado pela Constituição de 1988, pressupõe a construção hierárquica de planos de ordenação do território com amplitudes e enfoques diversos, os quais seguiriam basicamente o esquema abaixo, sugerido por José Afonso da Silva ${ }^{289}$ :

a) Planos urbanísticos nacionais, macrorregionais e setoriais, estabelecidos pela União e voltados a, respectivamente: definir diretrizes e objetivos gerais de desenvolvimento da rede urbana; coordenar o desenvolvimento das regiões geoeconômicas do país; e ordenar especialmente o território nacional ou regional;

b) Planos urbanísticos gerais e setoriais, elaborados pelos Estados federados e tendo por escopo, respectivamente: a ordenação da rede urbana estadual, respeitadas as diretrizes gerais federais; e a ordenação especial do território estadual; e

\footnotetext{
${ }^{286}$ Op. Cit., p. 101.

${ }^{287}$ Cf. item 3.2.

${ }^{288}$ José Afonso da Silva, Op. Cit., p. 101.

${ }^{289}$ Op. Cit., p. 106.
} 
c) Planos urbanísticos microrregionais, gerais, parciais e especiais, elaborados pelos Municípios, consistentes em, nesta ordem: planos de coordenação de regiões administrativas; plano diretor; zoneamento, alinhamento, etc.; e planos de renovação urbana, de distritos industriais, etc.

O Estatuto da Cidade, preenchendo uma condição de executoriedade das normas constitucionais atinentes à política urbana - contidas nos artigos 182 e 183 Constituição Federal de 1988 -, trouxe em seu texto as diretrizes e os objetivos gerais da política nacional de desenvolvimento urbano, regulando o uso da propriedade urbana em prol do bem coletivo, da segurança, do bem-estar dos cidadãos e do equilíbrio do meio ambiente. Essa lei indicou como instrumentos dessa política, dentre outros: os planos nacionais, regionais e estaduais de ordenação do território e de desenvolvimento econômico e social; o plano diretor; o zoneamento; os planos, programas e projetos setoriais; e os planos de desenvolvimento econômico e social (art. $4^{\mathrm{o}}$, I e III, $a, c, g$ e $h$ ).

Via de regra, é no nível municipal que a função urbanística é exercida mais concretamente, ou seja, que são mais frequentes os planos de natureza executiva, por decorrência direta da competência constitucional exclusiva dos Municípios para executar a política urbana (artigo 182), bem como para tratar de assuntos de interesse predominantemente local (artigo 30, I).

No entanto, em algumas matérias especiais, a atuação urbanística da União e dos Estados também se revela mais concretamente, por força da competência constitucional comum conferida a estes entes e aos Municípios para tanto. É o caso dos planos urbanísticos setoriais de defesa do patrimônio cultural, passíveis de serem estabelecidos nos âmbitos nacional, estadual e local.

Assim, em matéria de preservação do patrimônio cultural, é dever constitucional da União planejar o desenvolvimento da rede urbana nacional em função de uma política da defesa do patrimônio cultural (artigos 21, IX e 24, I, VII e VIII e $\left.\$ 1^{\mathrm{o}}\right)$.

Aos Estados impõe-se definir planos especiais de ordenação do seu território destinados à organização e delimitação de áreas de interesse público e que demandam 
limitações ao exercício do direito de propriedade, com vistas à proteção do patrimônio histórico, paisagístico, artístico, arqueológico (artigo 24, I, VII e VIII e $\left.\S 2^{\circ}\right)$. Nessa tarefa, o Estado deverá observar as diretrizes gerais fixadas pela União no plano nacional setorial relativo à matéria.

Os Municípios, por sua vez, preservam suas competências privativas para promover o adequado ordenamento de seu território (artigo 30, VIII), assim como para elaborar e implementar seu plano diretor (artigo 182), mas deverão conformar essas suas ações aos planos setoriais nacional e estadual de tutela do patrimônio cultural eventualmente definidos e a eles aplicáveis (artigo 30, IX) $)^{290}$.

Ocorre que até o presente momento, não se verifica no Direito positivo brasileiro um plano urbanístico federal setorial nessa matéria de preservação do patrimônio cultural. Tampouco são comuns planos setoriais sobre esse tema no âmbito legislativo estadual, mesmo sabendo-se que algumas dificuldades verificadas na prática estatal de defesa do patrimônio cultural urbano poderiam encontrar soluções nessas ações urbanísticas planificadoras, caso elas fossem implementadas.

Retomando a questão do tombamento estadual de bairros ${ }^{291}$, os possíveis impasses entre esta medida preservacionista e as intenções municipais de renovação urbana devem-se, também em grande parte, à ausência de um plano estadual setorial para essa matéria que preveja claramente as áreas sujeitas a proteção especial, os prazos de vigência desta proteção - após o que se discutiriam novos planos para essas áreas -, as metas a serem alcançadas até o final dessts prazos, os recursos eventualmente disponíveis para alcançar os fins colimados, etc.

Outro exemplo é o dos sítios históricos brasileiros declarados Patrimônio da Humanidade pela UNESCO. Eles carecem de um plano federal especial - devidamente aprovado por lei - que defina uma política consistente e de longo prazo para conservação desse Patrimônio. Política esta que garanta o aporte continuado de recursos para essas áreas, assim como a compatibilização da gestão desse Patrimônio, guardando-se, em todos os casos, o equilíbrio entre fluxos turísticos e serviços culturais oferecidos. Um plano

\footnotetext{
${ }^{290}$ José Afonso da Silva, op. Cit., p. 107

${ }^{291}$ Cf. item 4.2. supra.
} 
como este contribuiria para uma exploração adequada do turismo em nível nacional, sem desconsideração das necessidades de bem-estar e qualidade de vida dos habitantes dessas localidades ${ }^{292}$.

No nível municipal, os planos urbanísticos que mais têm aproveitamento aos fins da preservação são o plano diretor, o plano parcial do zoneamento, e o plano setorial de preservação de áreas de interesse cultural (artigo $4^{\circ}$, III, g).

O plano diretor, previsto nos artigos $4^{\circ}$, III, a e 39 a 42 da Lei 10.257/01, desempenha relevante tarefa na ordenação geral do território da cidade, constituindo o intrumento básico da política de desenvolvimento e expansão urbana. Esse plano, que deverá ser aprovado pela Câmara Municipal, visa a garantir o pleno exercício das funções sociais da cidade e da propriedade urbana, com vistas à satisfação das necessidades de bem-estar e qualidade de vida dos seus habitantes.

O artigo 41, IV da Lei 10.257/01 prevê a obrigatoriedade da adoção do plano diretor para cidades integrantes de áreas de especial interesse turístico. As áreas de especial interesse turístico foram criadas pela Lei federal $n^{\circ} 6.513 / 77$ e nesta definidas como "trechos contínuos do território nacional, inclusive suas águas territoriais, a serem preservados e valorizados no sentido cultural e natural, e destinados à realização de planos e projetos de desenvolvimento turístico" (artigo $3^{\circ}$ ).

Vale alertar, todavia, para a inconstitucionalidade daquela norma legal contida no artigo 41, IV da Lei 10.257/01, eis que ela cria nova hipótese de obrigatoriedade de elaboração do plano diretor pelos Municípios, além da prevista no parágrafo $1^{\circ}$ do artigo 182 da Constituição Federal (que o exige somente dos Municípios com mais de vinte mil habitantes). ${ }^{293}$ Assim, essa norma legal estaria violando o princípio da autonomia dos Municípios, no que se refere àqueles com vinte mil habitantes ou menos, os quais não foram obrigados pela Constituição a adotar planos diretores. Nesses casos, portanto, mesmo envolvendo áreas de especial interesse turístico, a

\footnotetext{
${ }^{292}$ Nessa linha foi criada, na Itália, a Lei de 20 de fevereiro de 2006, n. 77, que dispõe sobre medidas especiais de tutela e fruição dos sítios italianos de interesse cultural, paisagístico e ambiental, inseridos na Lista do Patrimônio Mundial, submetidos à tutela da UNESCO.

${ }^{293}$ Fernando Dias Menezes de Almeida. "Dos Instrumentos da Política Urbana". In MEDAUAR, Odete; ALMEIDA, Fernando Dias Menezes de (coord.). Estatuto da Cidade: Lei 10.257, de 10.07.2001, comentários. $2^{\text {a }}$ Ed. São Paulo: Revista dos Tribunais, 2004, p. 62, nota 19.
} 
decisão acerca da adoção ou não de plano diretor competirá a cada um destes pequenos Municípios. $^{294}$

De qualquer modo, quanto adotados planos diretores nas cidades onde exisitentes áreas de especial interesse turístico, eles deverão demonstrar-se compatíveis (ou compatibilizados) com o plano urbanístico setorial desenhado pela União para essas áreas - aqui vistas, cada uma delas, como um único e contínuo tecido urbano. Deverão ainda prever os meios adequados à exploração da vocação turística dessas áreas - consideradas as especificidades locais - com o melhor proveito para os seus habitantes (maior oferta de mão de obra, etc). Nota-se como a atividade planejadora, nesses casos, é ainda mais relevante.

É de se lembrar que o plano diretor também constitui mecanismo indispensável - uma espécie de ato-condição ${ }^{295}$ - para a adoção, pelos Municípios, do instrumento urbanístico da transferência do direito de construir, já apontado neste Capítulo como alternativa interessante à tutela estatal do patrimônio cultural no ambiente urbano (artigo 35 da Lei 10.257/01).

O zoneamento, por sua vez, é típico plano urbanístico parcial que define usos aos terrenos da cidade ${ }^{296}$. Poderá ser utilizado pelo Poder Público municipal para a finalidade específica de conservação de áreas de especial relevância cultural, sendo que, neste caso, a lei municipal que o instituir deverá identificar essas áreas, a fim de que nelas se apliquem as normas especiais garantidoras da tutela. Ao proceder a essa identificação, o zoneamento também age como instrumento de promoção, ou seja, de formação desse patrimônio.

\footnotetext{
${ }^{294}$ Na Ação Direta de Inconstitucionalidade n ${ }^{\circ}$ 826/9, o Supremo Tribunal Federal declarou inconstitucional o caput artigo 195 da Constituição do Estado do Amapá, que estabelecia que "o plano diretor, instrumento básico da política de desenvolvimento econômico e social e de expansão urbana, aprovado pela Câmara Municipal, é obrigatório para os Municípios com mais de cinco mil habitantes". Entendeu-se, nessa ocasião, semelhantemente ao quanto exposto acima no caso dos municípios que possuem áreas de especial interesse turístico em seu território, ou seja, que a norma constitucional estadual em questão "violou o princípio da autonomia dos municípios com mais de cinco mil e até vinte mil habitantes". Relator Ministro Sydney Sanches, v.u., j. 17 set. 1998.

${ }^{295}$ Cf. Jacintho Arruda Câmara, "Plano Diretor", In Adilson Abreu Dallari; Sérgio Ferraz (coord.), Estatuto da Cidade..., p. 323-324.

${ }^{296}$ Cf. Fernando Alves Correia, O plano urbanístico e o princípio da legalidade, p. 37.
} 
Essa tutela oferecida pelo zoneamento implica certo grau de limitação geral e abstrata ao exercício do direito de propriedade por todos os proprietários de imóveis que se encontrem em uma mesma área especial de proteção na cidade. $\mathrm{O}$ zoneamento definirá, assim, o conteúdo do direito de propriedade nessas localidades, com vistas a conformá-lo aos anseios sociais de preservação de valores culturais ${ }^{297}$. Contudo, não será por meio deste instituto que o poder público poderá exigir desses proprietários prestações positivas voltadas à preservação de bens culturais ${ }^{298}$. De efeito, as principais ações compreendidas nos planos de zoneamento são as seguintes:
a) delimitação das áreas e categorização dos tipos de uso;
b) fixação de dimensões mínimas dos lotes;
c) fixação dos coeficientes de edificação admitidos em cada área;
d) fixação das taxas de ocupação das distintas áreas de uso;
e) fixação de recuos fronteiros, laterais e de fundos. ${ }^{299}$

O zoneamento constitui importante ferramenta especialmente para aqueles Municípios que não contam com órgãos especiais de preservação dentro da sua estrutura organizacional administrativa. Também, de um modo geral, ele é relevante por permitir que outros instrumentos de política urbana igualmente úteis a essa preservação sejam conjugados à sua aplicação.

Assim, por exemplo, o Município de São Paulo adotou o zoneamento como mecanismo auxiliar aos fins de preservação por meio do seu Plano Diretor Estratégico, tendo estabelecido que os imóveis classificados como Z8-200 pela lei de zoneamento $^{300}$ seriam enquadrados como Zonas Especiais de Proteção Cultural -

\footnotetext{
${ }^{297}$ Desde que essa conformação não retire a funcionalidade do bem ao proprietário, conforme observado por Celso Antonio Bandeira De Mello, "Natureza Jurídica do Zoneamento. Efeitos”, In Estudos de Direito Público, a. I, n. 1, jan-jun/1982, p. 10.

${ }^{298}$ Cf. Celso Antonio Bandeira de Mello, "Natureza Jurídica do Zoneamento. Efeitos”, In Estudos de Direito Público, a. I, n. 1, jan-jun/1982, p. 6.

${ }^{299}$ Idem, ibidem, p. 13.

${ }^{300}$ Lei municipal $n^{\mathrm{o}} 13.885$, de 25 de agosto de 2004.
} 
ZEPEC, sendo-lhes autorizado aplicar o mecanismo da transferência do direito de construir $^{301}$.

Uma outra medida que pode ser conciliada com o zoneamento é o benefício de redução ou isenção do Imposto sobre a Propriedade Predial e Territorial Urbana IPTU nessas zonas especiais de proteção ${ }^{302}$.

De uma maneira geral, a grande vantagem dos planos urbanísticos, em comparação com os outros instrumentos analisados neste Capítulo - ainda que todos eles sejam reconhecidamente úteis, ao seu modo, à causa preservacionista -, é a visão de conjunto que aqueles são capazes de conferir ao universo patrimonial cultural urbano.

Essa visão de conjunto, ou seja, de síntese dos bens culturais presentes no ambiente urbano, proporcionada por esses planos urbanísticos, atende perfeitamente aos anseios contemporâneos de conservação e perpetuação de valores que não se resumem mais apenas às feições estéticas excepcionais materializadas em monumentos pontuais pelo território da cidade, mas se espalham pelo tecido urbano, projetando-se amplamente sobre diversas dimensões da cidade, inclusive sobre as práticas e as manifestações culturais que nela cotidianamente se realizam. Nesse sentido, vale destacar a lição do urbanista Paulo Ormindo de Azevedo:

\begin{abstract}
A preservação da cidade, ou parte dela, não pode se restringir, portanto, ao artefato material, ignorando as duas outras dimensões urbanas, as práticas sociais e os sentidos associados. Sem essa integração, a cidade perde a sua vida, vira sítio arqueológico, ou pior, parque temático. Ao contrário dos monumentos arquitetônicos e
\end{abstract}

\footnotetext{
${ }^{301}$ Esse comando vem expresso no Plano Diretor do Município de São Paulo (Lei n ${ }^{\circ} 13.430$, de 13 de setembro de 2002) nos seguintes termos: “Art. 168. As Zonas de preservação Cultural - ZEPEC são porções do território destinadas à preservação, recuperação e manutenção do patrimônio histórico, artístico e arqueológico, podendo se configurar como sítios, edifícios ou conjuntos urbanos. $§ 1^{\circ}$. Os imóveis ou áreas tombadas ou preservadas por legislação Municipal, Estadual ou Federal, bem como os imóveis classificados como Z8-200 por Lei Municipal, enquadram-se como ZEPEC; §2 Aplica-se às edificações particulares localizadas em ZEPEC a transferência do potencial construtivo, conforme disposto nos artigos 217,218 e incisos I e II do artigo 219 desta lei."

302 Cite-se, como exemplo, a Lei $\mathrm{n}^{\mathbf{o}}$ 12.350/97, do Município de São Paulo, que permite a isenção do pagamento do IPTU por até dez anos para prédios de relevância cultural restaurados, e a Lei $\mathrm{n}^{\circ}$ 10.598/88, também do Município de São Paulo, que permite a dedução de 50\% do IPTU para restauração de edificações localizadas no entorno de bem considerado de relevância cultural.
} 
objetos de arte, a cidade nunca é uma obra acabada, virtualmente perfeita, como na tradição clássica. O congelamento da cidade significaria sua morte. $\mathrm{O}$ que podemos conservar é algumas partes ou componentes da cidade, como os monumentos, tendo em vista não só o passado, mas especialmente o futuro. ${ }^{303}$

Um tratamento adequado dessa temática seria, assim, aquele que estabelecesse planos de ações concretas para essas áreas, de vigência limitada no tempo, após a qual seriam apurados os resultados obtidos e, eventualmente, revistos esses planos, reconhecendo-se, desse modo, que a cidade não é estática, tampouco os seus valores culturais. E que o que se elegeu hoje como patrimônio poderá não ser entendido dessa mesma forma no futuro - e vice-versa.

Além disso, esse modo de visualização do patrimônio - na sua globalidade -, dispensado pelo plano urbanístico, sempre quando associado à técnica do inventário, possibilita uma identificação mais precisa das áreas de maior risco de desfiguração. Esse fato contribui para que sejam priorizados os investimentos públicos nessas áreas mais sensíveis.

A propósito do inventário - oportunamente lembrado pelo constituinte de 1988 ao dispor sobre os modos de tutela do patrimônio cultural brasileiro -, é de se ressaltar que este mecanismo, em que pese a sua natureza meramente informativa, ou seja, de simples documento que relaciona, descreve detalhadamente e qualifica um conjunto de bens, poderá produzir efeitos significativos sobre a tutela do patrimônio cultural urbano, a depender do modo como aplicado. ${ }^{304}$

Assim, conforme comentado, áreas de risco de perda patrimonial poderão ser facilmente identificadas se se contar com um banco de dados completo, integrado com outras instâncias governamentais e em constante atualização.

\footnotetext{
303 "Comentário 4: A cidade como obra aberta”, In Victor Hugo Mori et alli (orgs.), Patrimônio: Atualizando o debate, p. 65 .

${ }^{304} \mathrm{O}$ inventário é comumente lembrado como mecanismo de preservação em diversas normas e documentos internacionais envolvendo essa matéria. Como exemplo, cite-se a Recomendação $n^{\circ} \mathrm{R}$ (95) 3, do Conselho da Europa.
} 
Também quando se garante a ampla publicação do inventário, este é capaz de transformar-se em verdadeiro veículo de comunicação, agindo em três diferentes níveis: $1^{\circ}$ ) de conscientização popular; $2^{\circ}$ ) de divulgação interna, entre os vários órgãos da administração pública federal, estadual e municipal; e $3^{\circ}$ ) de comunicação entre os proprietários de imóveis e os órgãos de preservação. ${ }^{305} \mathrm{~A}$ conscientização popular poderá dar causa, por exemplo, a reações comunitárias à destruição de edifícios inventariados, mesmo que eles não tenham sido tombados. Quando essas reações ganham força e notoriedade, os interesses especulativos nessas áreas tendem a se dissipar, direcionando-se para outras localidades, menos conflituosas. Já a divulgação e o intercâmbio de invetários entre as Administrações Públicas federal, estadual e municipal, permitem uma maior apreensão, pelos diferentes órgãos públicos, dos imóveis detentores de valor cultural que se encontram distribuídos nos territórios em que atuam e da disponiblidade destes imóveis para ocupação e uso por esses órgãos. E quanto aos proprietários de imóveis de valor cultural e sua relação com os órgãos preservacionistas, o inventário pode facilitar a comunicação entre eles, mediante a oferta de informação detalhada sobre o imóvel privado inventariado, assim como de assessoria técnica para obras de conservação ou adaptação funcional. ${ }^{306}$

Por fim, o inventário também aproveita aos fins de planejamento urbano, nos níveis nacional, regional e local, nas situações em que suas informações sobre imóveis e zonas especiais de interesse cultural tornam-se disponíveis aos órgãos de planejamento e ordenação do território, favorecendo a elaboração de planos urbanísticos - especialmente de planos diretores - mais sensíveis à problemática do patrimônio. $^{307}$

Na Itália, o Código dos Bens Culturais e da Paisagem, publicado em 2004, passou a conceber juridicamente a paisagem não mais como uma beleza natural, mas como um

\footnotetext{
${ }^{305}$ Paulo Ormindo de Azevedo, "Patrimônio Edificado: Inventariar ou classificar?", In Primeiras Jornadas Luso-Brasileiras do Património: Património Edificado. Comunicações, Actas, Conclusões, p. 58.

${ }^{306}$ Idem, Ibidem, p. 58. Esse autor relata a experiência do Instituto do Patrimônio Artístico e Cultural do Estado da Bahia, em que o inventário produzido no âmbito estadual teve também essa função de aproximação entre este órgão e os proprietários de imóveis inventariados.

${ }^{307}$ Idem, Ibidem, p. 58.
} 
documento. Diante dessa nova perspectiva, tem-se procurado perceber todo o território italiano como um grande arquivo da história do homem e da natureza, em contínua transformação, misturando alguns traços do passado aos do presente. Registra-se, nesse País, a prática recente de aproveitamento dos dados relativos ao patrimônio cultural urbano na gestão do território. Conforme relata Rafael Winter Ribeiro,

\footnotetext{
"há algumas décadas a Itália tem se engajado através do governo central com o Instituto Central para o Catálogo e a Documentação, ou através dos governos locais (regiões, províncias, municípios), num trabalho de recenseamento de seu patrimônio histórico. Nesse sentido, os bancos de dados já difundidos no passado foram largamente utilizados na gestão urbana e, em menor medida, na gestão do território, para completar uma leitura sumária dos eventos históricos dos lugares, segundo as épocas e as grandes constantes geográficas e culturais" ${ }^{, 308}$.
}

Esse intercâmbio de informações entre os órgãos de preservação e os de gestão urbana revela-se essencial tanto para uma remodelação ou transformação de áreas marginalizadas ou degradadas da cidade com a maior compatibilidade e o maior respeito possíveis em relação aos elementos ali preexistentes, quanto para a escolha adequada dos intrumentos urbanísticos capazes de atender às necessidades de proteção patrimonial da área considerada e, ao mesmo tempo, de causar o menor condicionamento possível aos interesses individuais dos proprietários. Com um planejamento urbano que leve em conta os dados de um inventário cultural, é possível também definir incentivos fiscais municipais, estaduais e para proprietários e promotores de projetos de restauro em áreas previamente identificadas.

${ }^{308}$ Rafael Winter Ribeiro, Paisagem Cultural e Patrimônio, p. 58. 


\section{Considerações Finais}

Partindo-se de uma constatação inicial de que, juridicamente, a preservação estatal do patrimônio cultural urbano deve ser procedida dispensando-se uma visão ambiental desse patrimônio, ou seja, de conjunto, a presente tese buscou demonstrar que o alcance desta finalidade última dependerá da adequada a articulação das competências dos entes incumbidos dessa preservação pela Constituição Federal, assim como da adoção de mecanismos que proporcionem uma gestão integrada e planejada desse patrimônio.

Em linhas gerais, analisou-se primeiramente o modo como evoluíram, na doutrina internacional, os fundamentos para a ação do Estado na preservação do patrimônio cultural. Viu-se que existe uma proximidade entre as finalidades últimas buscadas pelas normas preservacionistas e as buscadas pelas normas urbanísticas em geral, qual seja, a satisfação do bem-estar e da qualidade de vida aos indivíduos. Nessa linha, sustentou-se que a preservação do patrimônio cultural, quando no ambiente urbano, é modo de exercício da atividade urbanística, devendo levar em conta sempre o conjunto de normas e princípios aplicáveis ao direito urbanístico.

Quanto ao objeto de preservação, foram apontadas as interessantes contribuições de organizações internacionais no âmbito conceitual do patrimônio cultural urbano. A UNESCO e o Conselho da Europa, por exemplo, vêm desenvolvendo abordagens mais ampliadas do patrimônio, para o nível da globalidade da paisagem.

Verificou-se que, no Brasil, a atual concepção jurídica de patrimônio cultural vem consagrada no plano constitucional, marcadamente com a intenção de reforçar o status do patrimônio como um direito social, disposto na ordem vigente em mesmo patamar que o direito de propriedade - o qual, aliás, há tempos comporta em si uma função social. Essa concepção jurídica de patrimônio revela-se muito mais próxima dos valores populares cultivados nos âmbitos local e regional, compatibilizando-se com os anseios e interesses ali manifestados. 
Quanto aos sujeitos incumbidos de - ou legitimados a - agir, no Brasil, pela preservação do patrimônio cultural, verificou-se que, não obstante na texto constitucional de 1934 já se tivesse atribuído comumente a todos os entes federados o dever de proteção do patrimônio histórico e artístico nacional, as atividades de tutela, na prática, iniciaram-se de maneira concentrada, pela União, por meio do Serviço de Patrimônio Histórico e Artístico Nacional - SPHAN. Nesse início, as ações preservacionistas voltavam-se basicamente à conservação intacta ou ao restabelecimento da integridade estética de edificações, estas então valorizadas pelo seu caráter excepcional, ou seja, pela sua monumentalidade.

A descentralização dessas atividades preservacionistas dentro da estrutura do Estado Federal brasileiro ocorreu paulatinamente, ao longo de décadas, tendo sido mais fortemente sentida somente a partir dos anos 60, quando começaram a ser criados órgãos preservacionistas estaduais, seguidos dos órgãos municipais de mesma natureza, estes constituídos em grande parte nos anos 80. Foi comentada a experiência do Programa de Cidades Históricas, na década de 1970, que buscava o aproveitamento dos potenciais turísticos desse patrimônio para o desenvolvimento econômico local e no bojo do qual se desenvolveu marcadamente a ideia de um tratamento mais abrangente do patrimônio, baseado em planos urbanísticos.

Essa descentralização que hoje caracteriza as ações preservacionistas, ao permitir uma maior proximidade dos cidadãos com as decisões políticas envolvendo seus interesses de tutela de valores culturais, pode contribuir, em certa medida, para o exercício da democracia participativa. No presente trabalho, verificou-se que vem sendo perseguida a garantia de envolvimento da sociedade nas políticas de preservação do patrimônio cultural urbano e que, nesse sentido, a consagração constitucional da necessária colaboração da comunidade na realização desse direito, associada à previsão legal de gestão democrática da cidade, constituem as primeiras porém reconhecidamente grandes - conquistas. No plano prático, o crescente e recorrente uso de mecanismos jurisdicionais para tutela desse patrimônio são mostras significativas dessa maior participação.

Também a colaboração internacional tem sido exercida nessa matéria, de maneira direta e indireta. Diretamente, por meio da assistência técnica e financeira 
prestada pela UNESCO à salvaguarda de bens culturais eleitos como Patrimônio da Humanidade. No Brasil, essa assistência faz-se presente desde 1980, quando a cidade de Ouro Preto figurou como primeira localidade brasileira inscrita na Lista do Patrimônio Mundial da UNESCO. Indiretamente, em função das contribuições da UNESCO, do ICCROM, do ICOMOS, da OEA e do Conselho da Europa, por meio de suas produções técnicas e normativas, para o desenvolvimento do tema.

$\mathrm{Na}$ presente tese, sustentou-se que essa ampla ramificação de entes diretamente envolvidos com a tutela do patrimônio cultural guarda estreita relação com pelo menos dois fenômenos de ambitude mundial: um primeiro, consistente na tendência contemporânea de diluição e neutralização do poder estatal - especialmente em se envolvendo interesses difusos. E um segundo, relativo aos efeitos nocivos ao patrimônio cultural produzidos - ou ao menos ameaçados - em maior escala pelo acelerado crescimento populacional e pelo vertiginoso processo de urbanização, fortemente sentidos especialmente na segunda metade do século XX. No Brasil, esses fatores, associados à carência de recursos técnicos e administrativos experimentada pelo órgão federal de preservação já na década de 60 , foram decisivos para uma reconsideração da política preservacionista centralizadora adotada até então.

Apurou-se que a atual Constituição Constitucional de 1988 seguiu conferindo competência executiva comum a União, Estados, Distrito Federal e Municípios para cuidar desse patrimônio e passou a prever expressamente a competência legislativa concorrente não cumulativa para a matéria, reservando à União um nível normativo superior - para fixação de princípios e normas gerais -, e deixando aos Estados e Municípios a complementação legislativa, de acordo como as peculiaridades regionais e locais.

Demonstrou-se, ademais, que essas competências são irrenunciáveis e indelegáveis e que a responsabilidade pela defesa do patrimônio cultural brasileiro recai sobre todos os entes da Federação, indistintamente, independentemente do grau de interesse predominante no bem cultural (se local, regional ou nacional), tendo em vista que a matéria envolve interesses públicos particularmente ameaçados, além de ser de grande relevância social. Buscou-se sustentar que deve haver um grande esforço de cooperação e coordenação entre os entes federados, sob a regência de 
normas gerais definidas pela União, a fim de que não haja prejuízos à matéria por questões ligadas a limites de espaços de competência. E apontou-se que, no entanto, os termos exatos dessa cooperação mútua para os fins de preservação do patrimônio cultural não foram devidamente definidos pelo Congresso Nacional até o presente momento.

Também se apurou que a Constituição de 1988 introduziu ineditamente disposições sobre a política urbana, tratando de atribuir expressamente competência concorrente a todos os entes para legislarem sobre direito urbanístico. Quanto à competência executiva, entretanto, o constituinte conferiu-a exclusivamente aos Municípios para "promover, no que couber, adequado ordenamento territorial, mediante planejamento e controle do uso, do parcelamento e da ocupação do solo urbano" (art. 30, VIII). Apontou-se para a dúvida muitas vezes suscitada quanto às competências da União e dos Estados para atuarem na preservação do patrimônio cultural urbano, o que implicaria, em certo grau, ingerências destes entes sobre o ordenamento do território do Município. Acerca disso, demonstrou-se que aquela competência exclusiva municipal é referente a normas urbanísticas em geral e que, com relação à proteção do patrimônio cultural urbano, trata-se de um setor urbanístico especial, para o qual foi definida constitucionalmente competência comum da União, dos Estados, do Distrito Federal e dos Municípios.

Com base em dados coletados de pesquisas realizadas pelo IBGE entre 2000 e 2005, apontou-se para a situação vivenciada pela grande maioria dos Municípios brasileiros, de verdadeira dependência de recursos financeiros transferidos pela União e pelos Estados, o que reforça o entendimento de que a consecução do objetivo de preservação não prescinde da cooperação mútua dos entes federativos. Também se observou que, ainda assim, os Municípios suportam cerca de 50\% das despesas governamentais totais anuais realizadas na área da cultura e que estas, especificamente, representaram, entre 2003 e 2005, o ínfimo percentual de 0,2\% das despesas governamentais totais anuais.

Em relação aos Poderes Executivo e Legislativo, foi analisado que o artigo 216, parágrafo $1^{\text {o }}$ da Constituição de 1988 determinou-lhes providências de aparelhamento estatal, com vistas à adequada prestação da preservação do patrimônio 
cultural, indicando inclusive mecanismos hábeis à satisfação desse interesse público. Alguns desses mecanismos indicados, tais como a desapropriação e o tombamento, foram referidos também na Lei federal $\mathrm{n}^{\circ}$ 10.257/01 (Estatuto da Cidade) como típicos instrumentos de política urbana.

No âmbito legislativo, cotejou-se em detalhes o Decreto-lei no 25/37, em especial: sua relativa incompatibilidade com as atuais disposições constitucionais atinentes à concepção jurídica de patrimônio; a ausência de clareza quanto à natureza geral ou especial das normas nele contidas; suas limitações para cuidar de bens imateriais e mesmo de bens materiais significativos pelo seu conjunto, e não pela sua monumentalidade. Verificou-se que algumas distorções no emprego dessa lei surgiram já na década de 1940, ocorrendo com maior ênfase a partir da década de 1960, quando passaram a ser cada vez mais frequentes os casos de aplicação do tombamento para proteção de áreas urbanas. Viu-se também que a edição da Lei

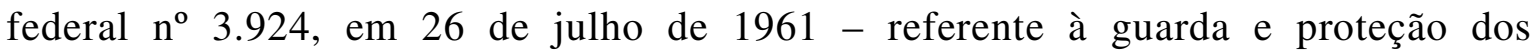
monumentos arqueológicos e pré-históricos -, e do Decreto federal no 3.551, em 4 de agosto de 2000 - que dispõe sobre o registro de bens imateriais -, são demonstrações claras da defasagem do Decreto-lei n 25/37 para, sozinho, “organizar a proteção do patrimônio histórico e artístico nacional”309.

Comentou-se que o Estatuto da Cidade, na condição de lei definidora das diretrizes gerais da política de desenvolvimento urbano, tratou de relacionar uma série de instrumentos urbanísticos disponíveis à finalidade de tutela do patrimônio cultural urbano, evidenciando a importância de que seja dispensada uma visão urbanística para este tema, num contexto de ordenação do território. Advertiu-se, no entanto, que dado documento legal não oferece maiores sistematizações a esta matéria específica. Até porque nem seria esse o seu escopo.

Daí que, para uma maior clareza da unidade do sistema de preservação do patrimônio cultural no Brasil e para uma melhor orientação dos mecanismos de tutela mais apropriados para cada caso, sugeriu-se, neste trabalho, a codificação da matéria em um único texto legislativo nacional.

\footnotetext{
${ }^{309}$ Como visto, eis o titulo do Decreto-lei $n^{\circ} 25 / 37$.
} 
Em reforço à tese de que a gestão do patrimônio cultural urbano deve ser buscada por meio de uma preservação integrada ao planejamento territorial, apresentaram-se, no Capítulo 4, uma série de mecanismos jurídicos específicos.

Primeiramente foi abordada a proteção internacional da UNESCO ao intitulado "Patrimônio Mundial", dedicando-se enfoque especial às recomedações feitas pelo Comitê do Patrimônio Mundial para a conservação das Cidades Históricas brasileiras. Essas recomendações evidenciaram as preocupações internacionais com que a gestão desse patrimônio fosse sempre procedida de maneira planejada e integrada com as principais questões sociais e econômicas das localidades envolvidas.

Em seguida, foram expostos alguns instrumentos disponíveis na ordem jurídica brasileira para as finalidades de preservação do patrimônio cultural.

Iniciando a abordagem com os institutos do tombamento e da desapropriação, o primeiro foi objeto de análise mais aprofundada, em razão dele ser, até os dias de hoje, o mecanismo a que mais frequentemente se recorre na prática, quando se pretende preservar algum tipo de valor cultural. Nesse contexto, ressaltou-se a maneira imprópria como o tombamento vem sendo empregado para resguardar tanto valores culturais imateriais - tais como manifestações culturais e modos de viver -, como para tutelar bens que necessitam ser lidos contextualmente, nos seus ambientes - e não isoladamente -, para que possam exprimir alguma significação cultural. Foram apontadas, nesse aspecto, as distorções do emprego do tombamento de uso e do tombamento de bairro. Também foram destacadas as necessidades de se garantir a participação da comunidade e dos órgãos municipais de ordenação urbana nas decisões preservacionistas envolvendo bairros, assim como de se produzirem - mais do que simples atos isolados de tombamento - planos urbanísticos setoriais que ofereçam uma visão de conjunto para essas áreas.

Com relação à desapropriação, viu-se que ela assume importância fundamental para os casos em que a proteção de valores culturais implica grandes sacrifícios ao direito de propriedade, pois ela garante ao expropriado a prévia e justa indenização em dinheiro. Também se sublinhou a importância da desapropriação para a demarcação de espaços públicos de convivência com valores culturais, já que este 
instrumento poderá incidir sobre quaisquer bens materiais - sejam eles detentores de valores culturais ou não -, desde que para a finalidade pública de preservação.

Verificou-se que o regime geral do Estudo Prévio de Impacto de Vizinhança (EIV), previsto no Estatuto da Cidade, assegura: a) um mínimo de envolvimento da comunidade local - principal sujeito de cultura - nos processos de aprovação de projetos potencialmente impactantes sobre a qualidade de vida em áreas urbanas; b) a consideração do patrimônio cultural - usualmente excluído do objeto do Estudo Prévio de Impacto Ambiental (EIA) - como elemento essencial de análise desses impactos; c) uma compreensão deste patrimônio cultural em seu aspecto de paisagem, integradora e sintetizadora de valores culturais materiais e imateriais, interagentes entre si e sujeitos a contínuas transformações, dada a essência dinâmica das cidades; e d) a possibilidade de conciliação dos interesses de desenvolvimento e de preservação no mesmo território urbano, mediante o estabelecimento de contrapartidas neutralizadoras dos potenciais impactos sobre o patrimônio cultural.

Tratou-se ainda, neste trabalho, da transferência do direito de construir também regida, em linhas gerais, pelo Estatuto da Cidade - e da utilidade desta medida para garantir a não-edificação em imóveis urbanos dotados de interesse cultural e situados, muitas vezes, em áreas de crescente valorização imobiliária e verticalização. Verificou-se que, segundo este mecanismo, lei municipal poderá autorizar proprietários de imóveis detentores de valor cultural a alienarem ou exercerem em outro local da cidade a parcela do direito de construir a que eles ordinariamente fariam jus - por integrar seus direitos de propriedade -, não fosse a afetação do imóvel. Sustentou-se também a aplicação da transferência do direito de construir conciliada com outros mecanismos, que identifiquem prévia e oficialmente os imóveis de significativa relevância cultural e que contribuam, de outros modos, para a garantia de uma completa satisfação do interesse público de preservação. Dispensou-se breve análise ao instituto do "transfer of development rights", desenvolvido pela doutrina norte-americana na década de 1970, no contexto da elaboração do Plano Urbanístico de Chicago, que buscava, em última análise, conferir integração social e sustentabilidade aos monumentos históricos situados em áreas valorizadas da cidade. 
Por fim, com vistas a reforçar a principal tese sustentada neste trabalho, qual seja, de que a tutela estatal do patrimônio cultural urbano deve ser conduzida de forma planejada, no mesmo contexto em que definidas as normas e ações de ordenação do território, dedicou-se atenção especial aos planos urbanísticos. Viu-se que, de acordo como o ordenamento pátrio, o planejamento urbanístico é imposição jurídica que recai sobre o Poder Público nos três níveis da Federação e que o desenvolvimento da rede urbana pressupõe a elaboração de planos urbanísticos gerais, regionais, locais, setoriais e parciais. Ressaltou-se também os deveres constitucionais: da União, de planejar o desenvolvimento da rede urbana nacional associadamente a um plano especial de defesa do patrimônio cultural brasileiro; dos Estados, de delimitar e organizar, por meio de planos setoriais, as áreas de interesse de preservação de seus respectivos territórios - respeitadas as normas gerais definidas pela União; e dos Municípios, de promover a adequada ordenação do seu território, por meio do plano diretor, do zoneamento, etc, mas conformando suas ações aos planos setoriais nacional e estadual de tutela do patrimônio cultural. Apontou-se para a carência, no Direito positivo brasileiro, de planos urbanísticos setoriais envolvendo essa matéria, mas que sua adoção, se associada à técnica de inventário, poderá trazer inúmeros benefícios ao propósito de preservação integrada do patrimônio cultural. 


\section{BIBLIOGRAFIA}

ALMEIDA, Fernanda Dias Menezes de. Competências na Constituição de 1988. $3^{\mathrm{a}}$ Ed. São Paulo: Atlas, 2005.

ALMEIDA, Fernando Dias Menezes de. "Dos Instrumentos da Política Urbana". In MEDAUAR, Odete; ALMEIDA, Fernando Dias Menezes de (coord.). Estatuto da Cidade: Lei 10.257, de 10.07.2001, comentários. 2a Ed. São Paulo: Revista dos Tribunais, 2004, p. 41-119.

ALVAREZ, José Luís Alvarez. Estudios sobre el Patrimonio Histórico Español y la Ley de 25 de Junio de 1985. Madrid: Editorial Civitas, 1989.

AMARAL, Marcos Jordão Teixeira do. "Da Gestão Democrática da Cidade". In MEDAUAR, Odete; ALMEIDA, Fernando Dias Menezes de (coord.). O Estatuto da Cidade: Lei 10.257, de 10.07.2001 - Comentários. São Paulo: Revista dos Tribunais, 2004.

ANDRADE, Rodrigo Melo Franco de. Rodrigo e o SPHAN : coletanea de textos sobre patrimônio cultural / Rodrigo Melo Franco de Andrade. Rio de Janeiro: MinC/ Pró-Memória, 1987.

AZEVEDO, Paulo Ormindo de. "Comentário 4: A Cidade Como Obra Aberta". In MORI, Victor Hugo; SOUZA, Marise Campos de; BASTOS, Rossano Lopes; GALLO, Haroldo (org.). Patrimônio: Atualizando o debate. São Paulo: 9ª SR/IPHAN, 2006, p. 65-69.

"Patrimônio Edificado: Inventariar ou classificar?", In Primeiras Jornadas Luso-Brasileiras do Património: Património Edificado - Comunicações, Actas, Conclusões. Lisboa: Calouste Gulbekian, 1984, p. 57-59.

BANDEIRA DE MELLO, Celso Antônio. Curso de Direito Administrativo. São Paulo, Malheiros, 2007.

. "Apontamentos sobre a desapropriação no direito brasileiro". In Revista de Direito Administrativo. v. 111, pp. 511-529, jan-mar/73. 
. "Natureza Jurídica do Zoneamento. Efeitos". In Estudos de Direito

Público. Associação dos Advogados da Prefeitura do Município de São Paulo. São Paulo, I, n. 1, jan./jun. 1982, pp. 3-21. . “Tombamento e Dever de Indenizar". In Revista de Direito Público, n.

81, jan-mar, 1987.

BARDET, Gastón. L’urbanisme, 8a. ed., Paris: PUF, 1975.

BASCHWITZ, Jacques, L'urbanisme et l Ammenagement foncier. Paris:Repertoires du Notariat Defrenois, 1972.

BASTOS, Celso Seixas Ribeiro. Curso de Direito Constitucional, São Paulo: Atlas, 1989.

BENEVOLO, Leonardo. Aux sources de l'urbanisme moderne. Paris: Horizons de France, 1963.

BENOIT, Francis. Le Droit Administratif Français. Paris: Dalloz, 1968.

BERÇAITZ, Miguel Angel. Problemas Jurídicos del Urbanismo. Buenos Aires: Abeledo Peirol, 1972.

BERCOVICI, Gilberto. Desigualdades Regionais, Estado e Constituição. São Paulo: Max Limonad, 2003.

BLEYON, Jean-Benoit. L'Urbanisme et La Protection des Sites: La Sauveguarde du Patrimoine Architectural Urbain. Paris: Librairie Générale de Droit et de Jurisprudence, 1979.

BOTELHO, Isaura. As dimensões da cultura e o lugar das políticas públicas. Disponível em: http://www.centrodametropole.org.br/pdf/Isaura.pdf. Acesso em: 20 dez. 2009.

BUCCI, Maria Paula Dallari. "Gestão Democrática da Cidade”. In DALLARI, Adilson Abreu; FERRAZ, Sérgio (coord.). Estatuto da Cidade: Comentários à Lei Federal 10.257/2001. São Paulo: Malheiros/SBDP, 2006.

. "O conceito de política pública em direito". In BUCCI, Maria Paula Dallari (org.). Políticas Públicas: Reflexões sobre o conceito jurídico. São Paulo: Saraiva, 2006, p. 1-49. 
CÂMARA, Jacintho Arruda. "Plano Diretor". In DALLARI, Adilson Abreu; FERRAZ, Sérgio (coord.). Estatuto da Cidade: Comentários à Lei Federal $n^{\circ} 10.257 / 2001.2^{\mathrm{a}}$ Ed. São Paulo: Malheiros/SBDP, 2006.

CAMMAROSANO, Márcio. “Tombamento - Realização de Obra Pública”, In Revista de Direito Público, n. 81, jan.-mar/87, p. 191-193.

CAMPOS FILHO, Cândido Malta. Cidades Brasileiras: Seu Controle ou o Caos. $3^{\text {a }}$ Ed. São Paulo: Studio Nobel, 1999.

CANASI, Jose. Tratado teórico practico de la expropriación pública. Segunda Parte. Buenos Aires: Sociedad Anónima Editora e Impresora, 1967.

CANOTILHO, José Joaquim Gomes. Direito Constitucional. Coimbra: Almedina, 1993. - Protecção do Ambiente e Direito de Propriedade: Crítica de Jurisprudência ambiental. Coimbra: Coimbra Editora, 1995.

CANTUCCI, Michele. La Tutela giuridica delle cose d'interesse artistico o storico. Padova: Casa Editrice Dott. Antonio Milani, 1953.

CARCELLER FERNANDEZ, Antonio. Instituciones de Derecho Urbanístico. Madri: Montecorvo, 1979.

CASTRIOTA, Leonardo Barci. "Intervenções sobre patrimônio urbano: modelos e perspectivas". In X Encontro Nacional da ANPUR, 2003, Belo Horizonte. Anais do X ENA. Belo Horizonte: ANPUR, 2003.

CASTRO, Sônia Rabello de. O Estado na Preservação de Bens Culturais. Rio de Janeiro: Renovar, 1991.

CEPAM - FUNDAÇÃO PREFEITO FARIA LIMA. O Solo Criado/Carta de Embu, São Paulo, 1977.

CHOAY, Françoise. A Alegoria do Patrimônio. São Paulo: Estação Liberdade: UNESP, 2006.

CYMBALISTA, Renato. "Estudo de Impacto de Vizinhança”, In Dicas Instituto Polis: Ideias para a ação municipal, $\mathrm{n}^{\circ} 192$, ano 2001.

COLLADO, Pedro Escribano. La Propiedad Privada Urbana: Encuadramiento y régimen. Madri: Montecorvo, 1979. 
CORTESE, Wanda. I Beni Culturali e Ambientali. Padova: Casa Editrice Dott. Antonio Milani, 1999.

CORREIA, Fernando Alves. O Plano Urbanístico e o Princípio da Legalidade. Coimbra: Almedina, 1989.

. "A Avaliação Ambiental de Planos e Programas: Um instituto de reforço da protecção do ambiente no direito do urbanismo", In Revista de Legislação e de Jurisprudência, Coimbra, a. 137, n. 3946, set/out.2007, p. 4-35.

CORREIA, José Manuel Sérvulo. Legalidade e autonomia contratual nos contratos administrativos. Coimbra: Almedina, 1987.

CORREIA, Miguel Brito. Enquadramento histórico das normas internacionais. In LOPES, Flávio; CORREIA, Miguel Brito (org.). Patrimônio Arquitetônico: Cartas, Recomendações e Convenções Internacionais. Lisboa: Livros Horizonte, 2004.

COSTONIS, John J. Space Adrift: Saving urban landmarks through Chicago Plan. University of Illinois Press, 1974.

CRETELla JUNIOR, José. "Regime Jurídico do Tombamento". In Revista de Direito Administrativo, v. 112, abr-jun/1973, pp. 50-68.

CURY, Isabelle (org). Cartas Patrimoniais. Brasília: IPHAN, 2004.

DALLARI, Adilson Abreu. "Tombamento". In DALLARI, Adilson Abreu; FIGUEIREDO, Lucia Valle (Coord.). Temas de Direito Urbanístico 2. São Paulo: Revista dos Tribunais, 1991, p. 11-16. . "Instrumentos da Política Urbana”. In DALLARI, Adilson Abreu; FERRAZ, Sérgio (orgs.). Estatuto da Cidade: Comentários à Lei Federal $n^{o}$ 10.257/2001. $2^{\mathrm{a}}$ Ed. São Paulo: Malheiros/SBDP, 2006.

DALLARI, Dalmo de Abreu. "A reforma constitucional e as novas competências dos Estados e Municípios”. In Anais do Seminário Pacto Federativo e as Relações Intergovernamentais. Curitiba: Instituto Municipal de Administração Pública, 1995, p. 25-51.

DELSON, Roberta Marx. Novas vilas para o Brasil-Colônia: Planejamento Espacial e Social no Século XVIII. Brasília: Alva-CIORD, 1997. 
DI LORENZO, Italo. Diritto Urbanistico. Turim: Unione Tipografico-Editrice Torinese, 1973.

DI PIETRO, Maria Sylvia Zanella. Direito Administrativo. São Paulo: Atlas, 2006.

DI SARNO, Daniela Campos Libório. Elementos de Direito Urbanístico. Barueri: Manole, 2004.

EISENMANN, Charles. "O Direito Administrativo e o Princípio da Legalidade". In Revista de Direito Administrativo, v. 56, abr-jun/1959, p. 47-70.

ENTERRIA, Eduardo Garcia de; ALFONSO, Luciano Parejo. Lecciones de Derecho Urbanístico. Madri: Civitas, 1979.

ENTERRIA, Eduardo Garcia de; FERNÁNDEZ, Tomás-Ramón. Curso de Derecho Administrativo. v. II. Madrid, Civitas, 1997.

ERDER, Cevat. Our Cultural Heritage: From Consciousness to Conservation, Museums and Monuments Series XX. Paris: UNESCO, 1986.

FERNÁNDEZ, Antonio Carceller. Introducción al derecho urbanístico. Madrid: Tecnos, 1993.

FERREIRA, Sergio de Andrea. "O tombamento e o devido processo legal". In Revista de Direito Administrativo, v. 208, abr-jun/97, pp. 1-34.

FERREIRA FILHO, Manoel Gonçalves. Comentários à Constituição Brasileira de 1988. v. 1. São Paulo: Saraiva, 2000.

FIGUEIREDO, Lúcia Valle. Disciplina Urbanística da Propriedade. São Paulo: Malheiros, 2005.

FONSECA, Maria Cecília Londres. O Patrimônio em Processo: Trajetória da Política Federal de Preservação no Brasil. Rio de Janeiro: UFRJ/Minc-IPHAN, 2005.

FORSTHOFF, Ernst. Tratado de Derecho Administrativo. Madrid: Instituto de Estudios Politicos, 1958.

FURTADO, Celso. O longo amanhecer: reflexões sobre a formação do Brasil. Rio de Janeiro: Paz e Terra, 1999.

GARRIDO FALLA, Fernando. Tratado de Derecho Administrativo. Madrid: Tecnos, 1992, v. 2. 
GIANNINI, Massimo Severo. Diritto Amministrativo. Milano, Giuffrè, 1993.

GILLI, Jean-Paul. Redéfinir le droit de propriété. Paris: Centre de Recherche d'urbanisme, 1975.

GORDILlO, Agustín. Tratado de Derecho Administrativo. Belo Horizonte: Del Rey/Fundación de Derecho Administrativo, 2003, tomo 1.

GRAU, Eros. Direito Urbano. Sao Paulo: Revista dos Tribunais, 1983.

GREGOROVIUS, Ferdinand Adolf. History of the City of Rome in the Middle Ages. Nova Iorque: AMS Press, 1967.

GRISOLIA, Mario. La tutela delle cose d'arte. Roma: 1952.

HUMBERT, Georges Louis Hage. "O Estudo do Impacto de Vizinhança como Instrumento de Proteção ao Meio Ambiente Cultural". In Fórum de Direito Urbano e Ambiental - FDUA. Belo Horizonte, ano 5, n. 27, p. 3323-3326, maio/jun. 2006.

JACQUIGNON, Louis. Le droit de l'urbanisme. Paris: Eyrolles, 1975.

LAUBADÈRE, André de. Traite Élémentaire de Droit Administratif. Paris: Librairie Générale de Droit et de Jurisprudence, 1999.

LAZARO, Luis Layana. Conceptos urbanisticos fundamentales sobre el suelo urbano en la jurisprudencia. Madri: Civitas, 1987.

LEFÈBVRE, Henri. O Direito à cidade. São Paulo: Centauro, 2008.

LEITE, Rogério Proença. Contra-Usos da Cidade: Lugares e Espaço Público na Experiência Urbana Contemporânea. Campinas: Unicamp/UFS, 2004.

LIMA, Ruy Cirne, “Das servidões administrativas”, In Revista de Direito Público, v. 5, p. $18-27$.

LOPES, Flávio. "Evolução do pensamento contemporâneo através da leitura de normas internacionais". In LOPES, Flávio; CORREIA, Miguel Brito (org.). Patrimônio Arquitetônico: Cartas, Recomendações e Convenções Internacionais. Lisboa: Livros Horizonte, 2004.

MATA-MACHADO, Bernardo Novais da. "Participação Política e Conselhos de Cultura: Uma proposta". In FARIA, Hamilton; MOREIRA, Altair José; VERSOLATO, Fernanda (org.). Você Quer um Bom Conselho? Conselhos 
Municipais de Cultura e Cidadania Cultural. São Paulo: Instituto Polis, 2005. Disponível em: http://www.polis.org.br/publicacoes_lista.asp?cd_serie=6. Acesso em: 20 dez. 2009.

MACHADO, Carlos Augusto A. "Tombamento: um instituto jurídico", In DALLARI, Adilson Abreu; FIGUEIREDO, Lúcia Valle (org.), Temas de Direito Urbanístico 1, São Paulo: Revista dos Tribunais, 1987, p. 23-51.

MACHADO, Paulo Affonso Leme. Ação Civil Pública e Tombamento. São Paulo: Revista dos Tribunais, 1986. . Estudos de Direito Ambiental. São Paulo: Malheiros, 1994. Direito Ambiental Brasileiro. São Paulo: Revista dos Tribunais, 1994. . "Tombamento: Instrumento jurídico de proteção do patrimônio natural e cultural”, In Revista dos Tribunais, v.563, set./1982, p. 15-40.

MANCUSO, Rodolfo de Camargo. Ação Civil Pública: em Defesa do Meio Ambiente, do Patrimônio Cultural e dos Consumidores. $9^{\text {a }}$ Ed. São Paulo: Revista dos Tribunais, 2004.

MARIANI, Alayde. "A memória popular no registro do patrimônio". In Revista do Patrimônio Histórico e Artístico Nacional, n. 28, 1999, p.156-173.

MARQUES NETO, Floriano de Azevedo. "Outorga onerosa do direito de construir (solo criado)". In DALLARI, Adilson Abreu; FERRAZ, Sérgio (coord.), Estatuto da Cidade: Comentários à Lei Federal 10.257/2001. São Paulo: Malheiros/SBDP, 2006, p.224-246.

MARTINI, Gastone. Disciplina urbanistica e tutela del patrimonio storico, artistico e paesistico. Milão: Giuffré, 1970.

MEDAUAR. Odete. Direito Administrativo em Evolução. $2^{\mathrm{a}}$ Ed. São Paulo: Revista dos Tribunais, 2003.

. "Diretrizes Gerais". In MEDAUAR, Odete; ALMEIDA, Fernando Dias Menezes de (coord.). Estatuto da Cidade: Lei 10.257, de 10.07.2001, comentários. $2^{\mathrm{a}}$ Ed. São Paulo: Revista dos Tribunais, 2004, p. 15-40. 
MEDAUAR, Odete; OLIVEIRA, Gustavo Justino de. Consórcios Públicos: Comentários à Lei 11.107/2005. São Paulo: Revista dos Tribunais, 2006.

MENESES, Ulpiano Toledo Bezerra. "A cidade como bem cultural: áreas envoltórias e outros dilemas, equívocos e alcance na preservação do patrimônio ambiental urbano". In MORI, Victor Hugo; SOUZA, Marise Campos de; BASTOS, Rossano Lopes; GALlO, Haroldo (org.). Patrimônio: Atualizando o debate. São Paulo: 9a SR/IPHAN, 2006, p. 33-76.

MEIRELLES, Hely Lopes. Direito Administrativo Brasileiro. São Paulo: Revista dos Tribunais, 2003.

. Direito Municipal Brasileiro. 11ª Ed. São Paulo: Malheiros, 2000.

. Mandado de Segurança, Ação Popular, Ação Civil Pública, Mandado de Injunção, Habeas Data, Ação Direta de Inconstitucionalidade, Ação Declaratória de Constitucionalidade e Arguição de Descumprimento de Preceito Fundamental. WALD, Arnoldo; MENDES, Gilmar Ferreira (atual.). São Paulo: Malheiros, 2002. “"Tombamento e Indenização". In Revista de Direito Administrativo. v. 161, jul./set. 1985, p. 1-6. "Patrimônio Histórico. Tombamento". In Estudos de Direito Público. v. IV, n. 2, jul-dez/85, p. 71-77.

MONTEIRO, Yara Darcy Police; SILVEIRA, Egle Monteiro da. "Transferência do Direito de Construir", In DALLARI, Adilson Abreu; FERRAZ, Sérgio (coord.), Estatuto da Cidade: Comentários à Lei Federal 10.257/2001. São Paulo: Malheiros/SBDP, 2006, p. 289-299.

MORAND-DEVILLER, Jacqueline. Droit de l'urbanisme. Paris: Mémentos Dalloz, 1996.

MOREIRA, Altair José. "A Diversidade Cultural na Refundação do Local”. In FARIA, Hamilton; MOREIRA, Altair José; VERSOLATO, Fernanda (orgs.). Você quer um Bom Conselho? Conselhos Municipais de Cultura e Cidadania Cultural. Polis. Estudos, Formação e Assessoria em Políticas Sociais. São Paulo: Polis, 2005. Disponível em: http://www.polis.org.br/publicacoes_lista.asp?cd_serie=6. Acesso em: 20 dez. 2009. 
MOREIRA NETO, Diogo de Figueiredo. Introdução ao Direito Ecológico e ao Direito Urbanístico: Instrumentos Jurídicos para um Futuro Melhor. Rio de Janeiro/São Paulo: Forense, 1975.

MUKAI, Toshio. Direito e Legislação Urbanística no Brasil: História, teoria e prática. São Paulo: Saraiva, 1988.

NOIA, Fernanda da Cruz. Efeitos do tombamento sobre a propriedade privada. (Dissertação de mestrado). São Paulo: Faculdade de Direito - USP, 2006.

ORTIZ, Gaspar Ariño; MARTINEZ, Juan Miguel de la Cuetara. La protección juridica de los espacios naturales. Madri: Centro de Estudios de Ordenación del Territorio y Medio Ambiente, 1982.

OTERO, Paulo. Legalidade e Administração Pública: $O$ sentido da vinculação administrativa à juridicidade. Coimbra: Almedina, 2003.

PALMA, Giuseppe. Beni di Interesse Pubblico e Contenuto de la Proprietà. Napoles: Casa Editrice Dott. Eugenio Novene, 1971.

PASINI, Gastone. La tutela delle Bellezze Naturali. Napoli: Morano, 1967.

PIRES, Maria Coeli Simões. Da proteção ao patrimônio cultural. O tombamento como principal Instituto. Belo Horizonte: Del Rei, 1994.

PONTIER, Jean-Marie; RICCI, Jean-Claude; BOURDON, Jacques. Droit de la Culture. $2^{\mathrm{a}}$ Ed. Paris: Dallos, 1996.

REIS FILHO, Nestor Goulart. Contribuição ao Estudo da Evolução Urbana do Brasil (1500-1720). $2^{\text {a }}$ Ed. São Paulo: Pini. 2000.

. O Quadro da Arquitetura no Brasil. São Paulo: Perspectiva, 1973.

. São Paulo e outras cidades. São Paulo: Hucitec, 1994.

. "Desenvolvimento urbano e uma nova política de conservação". In

Cadernos de Pesquisa do LAP, n. 16, nov.-dez/1996, p. 28-38.

- "Por uma Nova Política de Conservação: Edifícios e Bairros Construídos no Século XX”. In Cadernos de Pesquisa do LAP, n. 16, nov.-dez/1996, p. 3-27. 
"Por uma nova política de preservação". Artigo publicado n'O Estado de São Paulo. 9 de janeiro de 2009, p. A2.

REZEK, José Francisco. Direito Internacional Público: Curso Elementar. São Paulo: Saraiva, 2006.

RIBEIRO, Rafael Winter. Paisagem Cultural e Patrimônio. Rio de Janeiro: IPHAN, 2007.

RIVERO, Jean. Droit Administratif. Paris, Dalloz, 1990.

RODRIGUES, José Eduardo Ramos. “A evolução da proteção do patrimônio cultural crimes contra o ordenamento urbano e o patrimônio cultural". In Temas de Direito Ambiental e Urbanístico. Advocacia Pública \& Sociedade, a. II, n. 3, 1988, p. 199225.

SANTOS, Marcelo de Oliveira Fausto Figueiredo. "Tombamento - Uma análise constitucional. In DALLARI, Adilson Abreu; FIGUEIREDO, Lucia Valle. Temas de Direito Urbanístico 1. São Paulo: Revista dos Tribunais, 1987, p. 52-73.

SANTOS, Márcia Walkiria Batista dos. "Dos Instrumentos da Política Urbana: Arts. 28 a 35”, In MEDAUAR, Odete; ALMEIDA, Fernando Dias Menezes de (coord.), Estatuto da Cidade: Lei 10.257, de 10.07.2001, comentários. 2a Ed. São Paulo: Revista dos Tribunais, 2004, p. 201-224.

SÃO PAULO (cidade). Secretaria Municipal de Cultura. Departamento do Patrimônio Histórico. O direito à memória: patrimônio histórico e cidadania / DPH. São Paulo: DPH, 1992.

SAVY, Robert. Droit de L'urbanisme. Paris: Presses Universitaires de France, 1981.

SCIFONI, Simone. "Patrimônio Mundial: Do ideal humanista à utopia de uma nova civilização". In Espaço e Tempo. GEOUSP. n. 14, São Paulo, 2003, p. 77-88. Disponível em: Www.geografia.fflch.usp.br/publicacoes/geousp/Geousp14/Geousp_14_Scifoni.h tm. Acesso em: 20 nov. 2009.

SESIN, Domingo S. Administração Pública. Atividade regulada, discricionária e técnica: Novos mecanismos de controle judicial. Análise Jurisprudencial. Buenos Aires: De Palma, 1994. 
SILVA, Carlos Medeiros da. "Patrimônio Histórico e Artístico Nacional Tombamento - Vizinhança - Desapropriação - Registro de Imóveis - Direitos de Terceiros", In Revista de Direito Administrativo, v. 108, p. 429-441.

SILVA, Fernando Fernandes da. As Cidades Brasileiras e o Patrimônio Cultural da Humanidade. São Paulo: Peirópolis/Edusp, 2003.

SILVA, José Afonso da. Aplicabilidade das Normas Constitucionais. São Paulo: Malheiros, 2004.

.Curso de Direito Constitucional Positivo. São Paulo: Malheiros, 1998.

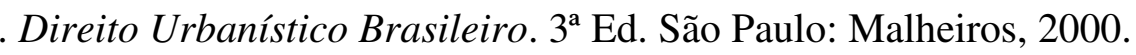
. Ordenação Constitucional da Cultura. São Paulo: Malheiros, 2001.

SPANTIGATI, Federico. Manual de Derecho Urbanistico. Madri: Montecorvo, 1973.

SUNDFELD, Carlos Ari. Direito Administrativo Ordenador. São Paulo: Malheiros, 2003. . "O Estatuto da Cidade e suas Diretrizes Gerais". In DALLARI, Adilson Abreu; FERRAZ, Sérgio (orgs.). Estatuto da Cidade: Comentários à Lei federal $n^{o}$ 10.257/2001. 2a Ed. São Paulo: Malheiros/SBDP, 2006.

SURAY, Jacques de. Droit de l'urbanisme et de l'environnement. Tomo I. Bruxelles: Établissements Émile Bruylant, 1974.

TELLES, Antonio Augusto de Queiroz. Tombamento e seu Regime Jurídico. São Paulo: Revista dos Tribunais, 1992.

TOBA, Marcos Maurício. "Dos Instrumentos da Política Urbana: Arts. 36 a 38”, In MEDAUAR, Odete; ALMEIDA, Fernando Dias Menezes de (coord.). Estatuto da Cidade: Lei 10.257, de 10.07.2001, comentários. $2^{\mathrm{a}}$ Ed. São Paulo: Revista dos Tribunais, 2004, p. 225-236.

TOLEDO, Carlos José Teixeira de. Patrimônio Cultural Urbanístico: um estudo sobre a tutela jurídica da memória coletiva. (Dissertação de Mestrado), SP, 1997.

VILLAÇA, Flávio. "Uma Contribuição para a História do Planejamento Urbano no Brasil”. In DEÁK, Csaba; SCHIFFER, Sueli Ramos (orgs.) O Processo de Urbanização no Brasil. São Paulo: Edusp/Fupam, 2004.

WEBER, Max. Economia e Sociedade. Brasília: UnB, 1999. 
WIRTH, Louis. "Urbanism as a way of life". In The american journal of sociology. vol. 44, n. 1, (jul. 1938), p. 1-24. Disponível em www.jstor.org. Acesso em 21 ago. 2009.

ZANOBINI, Guido. "L'attività amministrativa e la legge". In Scritti Vari di Diritto Pubblico. Milano: Dott. A. Giuffrè, 1955, p. 203-217.

\section{Documentos Internacionais}

Convenções sobre a Resolução Pacífica de Controvérsias Internacionais. Haia, 1899.

Convenções sobre a Resolução Pacífica de Controvérsias Internacionais. Haia, 1907.

CONSELHO DA EUROPA. Declaração de Amsterdã, 1975.

CONSELHO DA EUROPA. Carta do Patrimônio Arquitetônico Europeu, 1975.

CONSELHO DA EUROPA. Resolução 813 sobre a arquitetura contemporânea, 1983.

CONSELHO DA EUROPA. Recomendação $R$ (91) 13 para a proteção do patrimônio arquitetônico do século XX, 1991.

CONSELHO DA EUROPA. Convenção Europeia da Paisagem. 2000.

Declaração Internacional relativa a leis e costumes de guerra. Bruxelas, 1874.

ICOMOS. Carta sobre a Conservação e o Restauro de Monumentos e Sítios. Veneza, 1964.

ICOMOS. Estatuto Social. Paris, 1978.

ICOMOS. Carta sobre a salvaguarda dos jardins históricos. Florença, 1981.

ICOMOS. Declaração do México, 1985.

ICOMOS. Carta internacional sobre a salvaguarda das cidades históricas e áreas urbanas históricas. Washington, 1987. 
ICOMOS. Carta sobre o patrimônio construído vernáculo. México, 1999.

OEA. Normas de Quito, 1967.

OEA. Resolução de São Domingos, 1974.

SERVIÇO INTERNACIONAL DE MUSEUS. Carta de Atenas sobre o restauro de monumentos, 1931.

SOCIEDADE DAS NAÇÕES. Resolução sobre a conservação de monumentos históricos e de obras de arte, 1932.

UNESCO, ICCROM e ICOMOS. Documento de Nara, 1994.

UNESCO. Convenção para a proteção de bens culturais em caso de conflito armado. Haia, 1954.

UNESCO. Recomendação sobre a salvaguarda da beleza e do caráter das paisagens e dos sítios. Paris, 1962.

UNESCO. Conferência de Washington. 1965.

UNESCO. Convenção para a Proteção do Patrimônio Mundial, Cultural e Natural. Paris, 1972.

UNESCO. Recomendação sobre a salvaguarda dos conjuntos históricos e da sua função na vida contemporânea. Nairobi, 1976.

UNESCO. Constituição da Organização das Nações Unidas para a Educação, a Ciência e a Cultura, 2002.

UNESCO. WHC 93/CONF. 002/14. Paris, 1994.

UNESCO. WHC 2000/CONF. 204/21. Paris, 2000.

UNESCO. WHC 03/27. COM/7B decisão 27 COM 7B.85. Paris, 2003.

UNESCO. WHC 03/27. COM/7B decisão 27 COM 7B.86. Paris, 2003. 
UNESCO. WHC 03/27. COM/7B decisão 27 COM 7B.87. Paris, 2003.

UNESCO. WHC 04/28. COM/15B decisão 28 COM 15B.108. Paris, 2004.

UNESCO. WHC 09/33. COM/20 decisão 33COM/7B.133. Paris, 2009.

UNIÃO PANAMERICANA. Pacto de Roerich. Washington, 1935.

\section{Jurisprudência Mencionada}

BRASIL. SUPREMO TRIBUNAL FEDERAL. Embargos a Recurso Extraordinário ${ }^{\circ}$ 41.279, Relator Ministro A. M. Vilas-Boas, j. 9 set. 1965. In Revista de Direito Administrativo, v. 84, p. 155-165.

BRASIL. SUPREMO TRIBUNAL FEDERAL. Representação Constitucional $\mathrm{n}^{\circ}$ 1.312/RS, Relator Ministro Célio Borja, j. 27 out. 1988.

BRASIL. SUPREMO TRIBUNAL FEDERAL. Ação Direta de Inconstitucionalidade $n^{\circ}$ 826/9, Relator Ministro Sydney Sanches, v.u., j. 17 set. 1998.

BRASIL. SUPREMO TRIBUNAL FEDERAL. Recurso Extraordinário nº 219.292-1-MG,

Relator Ministro Octavio Gallotti, v.u., j.07 dez. 1999. In Revista dos Tribunais, v.782, p. 187-192.

BRASIL. SUPREMO TRIBUNAL FEDERAL. Recurso Extraordinário no 436.996-AgR, Relator Ministro Celso de Mello, v.u., j. 22 nov. 2005.

BRASIL. SUPREMO TRIBUNAL FEDERAL. Ação direta de Inconstitucionalidade $\mathrm{n}^{\circ}$ 2.544-9 - RS, Relator Ministro Sepúlveda Pertence, v.u., j. 28 jun. 2006.

BRASIL. SUPREMO TRIBUNAL FEDERAL. Ação Direta de Inconstitucionalidade $\mathbf{n}^{\circ}$ 1.706/DF. Relator Ministro Eros Grau, v.u., j. 9 abr. 2008.

BRASIL. SUPREMO TRIBUNAL FEDERAL. Recurso Extraordinário no 595.595-AgR, Relator Ministro Eros Grau, v.u., j. 28 abr. 2009.

BRASIL. SUPERIOR TRIBUNAL DE JUSTIÇA. Recurso Especial nº 34.006-SP, Relator Ministro Humberto Gomes de Barros, j. 25 out. 1993. 
BRASIL. SUPERIOR TRIBUNAL DE JUSTIÇA. Recurso Especial nº 52.905-SP, Relator Ministro Humberto Gomes de Barros, j. 14 dez. 1994.

BRASIL. SUPERIOR TRIBUNAL DE JUSTIÇA. Recurso Especial $n^{\circ}$ 188.781-PR, Relator Ministro Humberto Gomes de Barros, j. 20 set. 1999.

BRASIL. SUPERIOR TRIBUNAL DE JUSTIÇA. Recurso Especial $n^{\circ}$ 401.264/SP, Relatora Ministra Eliana Calmon, j. 05 set. 2002.

BRASIL. SUPERIOR TRIBUNAL DE JUSTIÇA. Recurso Especial $n^{\circ}$ 435.128/SP, Relator Ministro Luiz Fux; j. 11 fev. 2003.

BRASIL. SUPERIOR TRIBUNAL DE JUSTIÇA. Recurso Especial $\mathrm{n}^{\circ}$ 665.791/SP, Relator Ministro Castro Meira; j. 05 abr. 2005.

TRIBUNAL FEDERAL DE RECURSOS. Apelação Cível nº 1.515-PB, j. 6 nov. 1951. In Revista dos Tribunais, v. 222, p. 559 e ss.

SÃO PAULO (Estado). TRIBUNAL DE JUSTIÇA. Apelação Cívil nº 83.211-1, Relator Desembargador Ernani de Paiva, j. 19 mar. 1987.

SÃO PAULO (Estado). TRIBUNAL DE JUSTIÇA. Apelação Cívil nº 112.282-1, Relator Desembargador Fonseca Tavares, v.u., j. 28 jun. 1989. In Revista de Jurisprudência do Tribunal de Justiça do Estado de São Paulo, LEX, v. 122, p.50-52.

RIO DE JANEIRO (Estado). TRIBUNAL DE JUSTIÇA. Agravo em Mandado de Segurança $\mathrm{n}^{\circ}$ 10.579, Relator Desembargador Orlando Carlos, j. 02 dez. 1959. In Revista de Direito Administrativo, v. 74, p. 229-232. 


\section{ANEXOS}

\section{Tabela I}

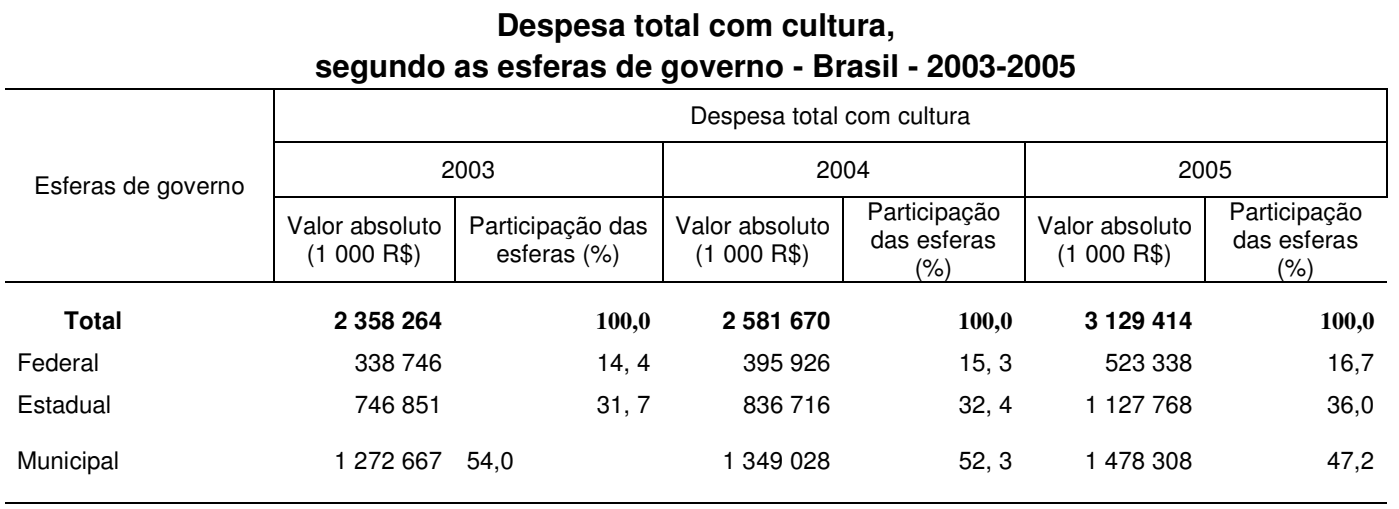

Fontes: Ministério da Fazenda, Secretaria do Tesouro Nacional, Sistema Integrado de Administração Financeira do Governo Federal - SIAFI; Execução orçamentária dos estados (1995-2006). Brasília, DF: Ministério da Fazenda, Secretaria do Tesouro Nacional, [200-]. Disponível em: <http://www.tesouro.fazenda.gov.br/estados_municipios/download/ exec_orc_estados.xls>. Acesso em: 2007; Finanças do Brasil: dados contábeis dos municípios 2003-2005. Brasília, DF: Ministério da Fazenda, Secretaria do Tesouro Nacional, v. 49-51, 2004-2006. Disponível em: <http://www.tesouro. fazenda.gov.br/estados_municipios/index.asp>. Acesso em: 2007; IBGE, Diretoria de Pesquisas, Coordenação de Contas Nacionais, Estatísticas Econômicas das Administrações Públicas 2003-2004; Perfil dos municípios brasileiros: cultura 2006. Rio de Janeiro: IBGE, 2007. Acompanha 1 CD-ROM. Acima do título: Pesquisa de Informações Básicas Municipais. 


\section{Tabela II}

Participação da despesa orçamentária com cultura no total da despesa orçamentária Brasil - 2003-2005

\begin{tabular}{|c|c|c|c|c|}
\hline Esferas & $\begin{array}{c}\text { Cultura } \\
(1000 \mathrm{R} \$)\end{array}$ & $\begin{array}{c}\text { Total } \\
(1000 \mathrm{R} \$)\end{array}$ & & $\begin{array}{l}\text { Participação da cultura } \\
(\%)\end{array}$ \\
\hline \multicolumn{5}{|c|}{2003} \\
\hline Total & 2358084 & 1208814474 & & 0,2 \\
\hline Federal & 338566 & 876456652 & 0,0 & \\
\hline Estadual & 746851 & 205044675 & 0,4 & \\
\hline Municipal & 1272667 & 127313147 & 1,0 & \\
\hline \multicolumn{5}{|c|}{2004} \\
\hline Total & 2581670 & 1282899039 & & 0,2 \\
\hline Federal & 395926 & 908148769 & 0,0 & \\
\hline Estadual & 836716 & 239836314 & 0,3 & \\
\hline Municipal & 1349028 & 134913956 & 1,0 & \\
\hline \multicolumn{5}{|c|}{2005} \\
\hline Total & 3129414 & 1538810372 & & 0,2 \\
\hline Federal & 523338 & 1106790731 & 0,0 & \\
\hline Estadual & 1127768 & 273529892 & 0,4 & \\
\hline Municipal & 1478308 & 158489749 & 0,9 & \\
\hline
\end{tabular}

Fontes: Ministério da Fazenda, Secretaria do Tesouro Nacional, Sistema Integrado de Administração Financeira do Governo Federal - SIAFI; Execução orçamentária dos estados (1995-2006). Brasília, DF: Ministério da Fazenda, Secretaria do Tesouro Nacional, [200-]. Disponível em: <http://www.tesouro.fazenda.gov.br/estados_municipios/download/ exec_orc_estados.xls>. Acesso em: 2007; Finanças do Brasil: dados contábeis dos municípios 2003-2005. Brasília, DF: Ministério da Fazenda, Secretaria do Tesouro Nacional, v. 49-51, 2004-2006. Disponível em: <http://www.tesouro. fazenda.gov.br/estados_municipios/index.asp>. Acesso em: 2007; IBGE, Diretoria de Pesquisas, Coordenação de Contas Nacionais, Estatísticas Econômicas das Administrações Públicas 2003-2004; Perfil dos municípios brasileiros: cultura 2006. Rio de Janeiro: IBGE, 2007. Acompanha 1 CD-ROM. Acima do título: Pesquisa de Informações Básicas Municipais. 


\section{Tabela III}

\section{Análise comparativa das despesas por funções consolidadas pelas três esferas de governo, segundo o tipo de função \\ Brasil - 2003-2005}

\begin{tabular}{|c|c|c|c|c|c|c|}
\hline \multirow{3}{*}{ Tipo de função } & \multicolumn{6}{|c|}{ Análise comparativa das despesas por funções consolidadas pelas três esferas de governo } \\
\hline & \multicolumn{2}{|c|}{2003} & \multicolumn{2}{|c|}{2004} & \multicolumn{2}{|c|}{2005} \\
\hline & $\begin{array}{c}\text { Valor } \\
\text { absoluto (1 } \\
000000 \mathrm{R} \$)\end{array}$ & $\begin{array}{c}\text { Participação } \\
\text { percentual (\%) }\end{array}$ & $\begin{array}{c}\text { Valor } \\
\text { absoluto (1 } \\
000000 \mathrm{R} \$ \text { ) }\end{array}$ & $\begin{array}{c}\text { Participação } \\
\text { percentual (\%) }\end{array}$ & $\begin{array}{c}\text { Valor } \\
\text { absoluto (1 } \\
000000 \mathrm{R} \$)\end{array}$ & $\begin{array}{c}\text { Participação } \\
\text { percentual (\%) }\end{array}$ \\
\hline Total & 1210274 & 100,0 & 1279221 & 100,0 & 1533676 & 100,0 \\
\hline Saúde & 75057 & 6,2 & 91412 & 7,1 & 99340 & 6,5 \\
\hline Educação & 87370 & 7,2 & 89928 & 7,0 & 102037 & 6,7 \\
\hline Cultura & 2359 & 0,2 & 2582 & 0,2 & 3129 & 0,2 \\
\hline Outras & 1045488 & 86,4 & 1095299 & 85,6 & 1329170 & 86,7 \\
\hline
\end{tabular}

Fontes: Ministério da Fazenda, Secretaria do Tesouro Nacional, Sistema Integrado de Administração Financeira do Governo Federal - SIAFI; Execução orçamentária dos estados (1995-2006). Brasília, DF: Ministério da Fazenda, Secretaria do Tesouro Nacional, [200-]. Disponível em: <http://www.tesouro.fazenda.gov.br/estados_municipios/download/ exec_orc_estados.xls>. Acesso em: 2007; Finanças do Brasil: dados contábeis dos municípios 2003-2005. Brasília, DF: Ministério da Fazenda, Secretaria do Tesouro Nacional, v. 49-51, 2004-2006. Disponível em: <http://www.tesouro. fazenda.gov.br/estados_municipios/index.asp>. Acesso em: 2007; IBGE, Diretoria de Pesquisas, Coordenação de Contas Nacionais, Estatísticas Econômicas das Administrações Públicas 2003-2004; Perfil dos municípios brasileiros: cultura 2006. Rio de Janeiro: IBGE, 2007. Acompanha 1 CD-ROM. Acima do título: Pesquisa de Informações Básicas Municipais. 


\section{Tabela IV}

Municípios, total e por faixas de participação das receitas de transferências correntes no total geral das receitas, segundo classes de tamanho da população dos municípios, Grandes Regiões e Unidades da Federação - 1998-2000

\begin{tabular}{|c|c|c|c|c|c|c|c|c|c|}
\hline \multirow{2}{*}{$\begin{array}{c}\text { Classes de tamanho } \\
\text { da população dos municípios, } \\
\text { Grandes Regiões e } \\
\text { Unidades da Federação }\end{array}$} & \multirow{2}{*}{$\begin{array}{c}\text { Total } \\
\text { de } \\
\text { municípios } \\
\text { (1) }\end{array}$} & \multicolumn{8}{|c|}{$\begin{array}{l}\text { Municípios, por faixas de participação das receitas de transferências correntes } \\
\text { no total geral das receitas }\end{array}$} \\
\hline & & Até $65 \%$ & $\begin{array}{c}\text { Mais de } \\
65 \% \text { a } \\
70 \%\end{array}$ & $\begin{array}{c}\text { Mais de } \\
70 \% \text { a } \\
75 \%\end{array}$ & $\begin{array}{l}\text { Mais de } \\
75 \% \text { a } \\
80 \%\end{array}$ & $\begin{array}{c}\text { Mais de } \\
80 \% \text { a } \\
85 \%\end{array}$ & $\begin{array}{c}\text { Mais de } \\
85 \% \text { a } \\
90 \%\end{array}$ & $\begin{array}{c}\text { Mais de } \\
90 \% \text { a } \\
95 \%\end{array}$ & $\begin{array}{l}\text { Mais de } \\
95 \%\end{array}$ \\
\hline \multicolumn{10}{|c|}{2000} \\
\hline Total & 5507 & 279 & 204 & 357 & 569 & 811 & 1018 & 1007 & 953 \\
\hline \multicolumn{10}{|l|}{ Classes de tamanho da população } \\
\hline Até 5000 hab. & 1409 & 33 & 28 & 53 & 102 & 185 & 302 & 348 & 288 \\
\hline De 5001 a 20000 hab. & 2652 & 83 & 70 & 143 & 273 & 405 & 528 & 491 & 506 \\
\hline De 20001 a 100000 hab. & 1224 & 100 & 66 & 118 & 164 & 203 & 178 & 159 & 158 \\
\hline De 100001 a 500000 hab. & 192 & 47 & 36 & 37 & 28 & 18 & 10 & 9 & 1 \\
\hline Mais de 500000 hab. & 30 & 16 & 4 & 6 & 2 & - & - & - & - \\
\hline \multicolumn{10}{|l|}{$\begin{array}{l}\text { Grandes Regiões e Unidades da } \\
\text { Federação }\end{array}$} \\
\hline Norte & 449 & 36 & 12 & 28 & 34 & 55 & 53 & 49 & 81 \\
\hline Rondônia & 52 & 4 & - & 3 & 5 & 7 & 7 & 11 & 8 \\
\hline Acre & 22 & 1 & 2 & 5 & 3 & 5 & 3 & 1 & 1 \\
\hline Amazonas & 62 & 16 & 7 & 12 & 9 & 6 & 3 & 2 & 1 \\
\hline Roraima & 15 & 3 & - & 1 & - & 3 & 2 & 2 & 2 \\
\hline Pará & 143 & 5 & 2 & 2 & 12 & 21 & 13 & 17 & 21 \\
\hline Amapá & 16 & 1 & 1 & - & 1 & 1 & 2 & - & - \\
\hline Tocantins & 139 & 6 & - & 5 & 4 & 12 & 23 & 16 & 48 \\
\hline Nordeste & 1787 & 42 & 40 & 51 & 95 & 178 & 270 & 387 & 566 \\
\hline Maranhão & 217 & 1 & 1 & 2 & 2 & 6 & 13 & 26 & 127 \\
\hline Piauí & 221 & 18 & 18 & 20 & 31 & 39 & 28 & 17 & 20 \\
\hline Ceará & 184 & 1 & 1 & 1 & 4 & 16 & 39 & 56 & 56 \\
\hline Rio Grande do Norte & 166 & 6 & 5 & 7 & 6 & 18 & 24 & 36 & 51 \\
\hline Paraíba & 223 & 2 & 3 & 3 & 11 & 22 & 38 & 62 & 77 \\
\hline Pernambuco & 185 & 3 & 3 & 5 & 9 & 22 & 26 & 49 & 60 \\
\hline Alagoas & 101 & 2 & 1 & 1 & - & 3 & 3 & 20 & 31 \\
\hline Sergipe & 75 & 3 & 2 & 2 & 2 & 5 & 13 & 20 & 26 \\
\hline Bahia & 415 & 6 & 6 & 10 & 30 & 47 & 86 & 101 & 118 \\
\hline Sudeste & 1666 & 113 & 84 & 165 & 251 & 278 & 327 & 265 & 141 \\
\hline Minas Gerais & 853 & 23 & 31 & 80 & 109 & 145 & 180 & 171 & 107 \\
\hline Espírito Santo & 77 & 4 & 3 & 6 & 12 & 15 & 17 & 11 & 9 \\
\hline Rio de Janeiro & 91 & 20 & 8 & 13 & 25 & 13 & 8 & 3 & 1 \\
\hline São Paulo & 645 & 66 & 42 & 66 & 105 & 105 & 122 & 80 & 24 \\
\hline Sul & 1159 & 74 & 46 & 82 & 153 & 242 & 282 & 196 & 80 \\
\hline Paraná & 399 & 36 & 19 & 28 & 44 & 81 & 93 & 63 & 32 \\
\hline Santa Catarina & 293 & 20 & 15 & 11 & 32 & 47 & 81 & 55 & 31 \\
\hline Rio Grande do Sul & 467 & 18 & 12 & 43 & 77 & 114 & 108 & 78 & 17 \\
\hline Centro-Oeste & 446 & 14 & 22 & 31 & 36 & 58 & 86 & 110 & 85 \\
\hline Mato Grosso do Sul & 77 & 7 & 2 & 6 & 5 & 9 & 16 & 25 & 7 \\
\hline Mato Grosso & 126 & 2 & 10 & 11 & 14 & 22 & 28 & 25 & 11 \\
\hline Goiás & 242 & 4 & 10 & 14 & 17 & 27 & 42 & 60 & 67 \\
\hline Distrito Federal & 1 & 1 & - & - & - & - & - & - & - \\
\hline
\end{tabular}

Fonte: IBGE, Diretoria de Pesquisas, Coordenação de População e Indicadores Sociais, Pesquisa de Informações Básicas Municipais $1999 / 2001$.

(1) Inclusive os ignorados e os sem declaração de existência. 


\section{Tabela V}

Municípios, total e por faixas de participação das receitas tributárias no total geral das receitas, segundo classes de tamanho da população dos municípios, Grandes Regiões e Unidades da Federação - 1998-2000

\begin{tabular}{|c|c|c|c|c|c|c|c|c|c|c|}
\hline \multirow{2}{*}{$\begin{array}{c}\text { Classes de tamanho } \\
\text { da população dos municípios, } \\
\text { Grandes Regiões e } \\
\text { Unidades da Federação }\end{array}$} & \multirow{2}{*}{$\begin{array}{l}\text { Total } \\
\text { de } \\
\text { municípios } \\
(1)\end{array}$} & \multicolumn{9}{|c|}{ Municípios, por faixas de participação das receitas tributárias no total geral das receitas } \\
\hline & & $\begin{array}{l}\text { Até } \\
0,5 \%\end{array}$ & $\begin{array}{l}\text { Mais de } \\
0,5 \% \text { a } \\
1 \%\end{array}$ & $\begin{array}{l}\text { Mais de } \\
1 \% \text { a } \\
1,5 \%\end{array}$ & $\begin{array}{c}\text { Mais de } \\
1,5 \% \text { a } \\
2 \%\end{array}$ & $\begin{array}{l}\text { Mais de } \\
2 \% \text { a } 3 \%\end{array}$ & $\begin{array}{l}\text { Mais de } \\
3 \% \text { a } 4 \%\end{array}$ & $\begin{array}{l}\text { Mais de } \\
4 \% \text { a } 6 \%\end{array}$ & $\begin{array}{l}\text { Mais de } \\
6 \% \text { a } \\
10 \%\end{array}$ & $\begin{array}{c}\text { Mais de } \\
10 \%\end{array}$ \\
\hline \multicolumn{11}{|c|}{2000} \\
\hline Total & 5507 & 444 & 661 & 640 & 501 & 684 & 477 & 580 & 569 & 642 \\
\hline \multicolumn{11}{|l|}{ Classes de tamanho da população } \\
\hline Até 5000 hab. & 1409 & 155 & 236 & 260 & 182 & 248 & 122 & 83 & 33 & 20 \\
\hline De 5001 a 20000 hab. & 2652 & 222 & 336 & 294 & 237 & 331 & 264 & 361 & 301 & 153 \\
\hline De 20001 a 100000 hab. & 1224 & 67 & 89 & 85 & 81 & 101 & 87 & 130 & 206 & 300 \\
\hline De 100001 a 500000 hab. & 192 & - & - & 1 & 1 & 4 & 4 & 6 & 29 & 141 \\
\hline Mais de 500000 hab. & 30 & - & - & - & - & - & - & - & - & 28 \\
\hline \multicolumn{11}{|l|}{$\begin{array}{l}\text { Grandes Regiões e Unidades da } \\
\text { Federação }\end{array}$} \\
\hline Norte & 449 & 80 & 64 & 53 & 32 & 32 & 26 & 24 & 23 & 14 \\
\hline Rondônia & 52 & 2 & 7 & 10 & 8 & 1 & 8 & 4 & 2 & 3 \\
\hline Acre & 22 & 4 & 4 & 4 & 4 & 3 & - & 1 & 1 & - \\
\hline Amazonas & 62 & 22 & 17 & 2 & 3 & 5 & 2 & 3 & 1 & 1 \\
\hline Roraima & 15 & - & 1 & - & - & - & - & 3 & 4 & 5 \\
\hline Pará & 143 & 19 & 21 & 19 & 5 & 7 & 12 & 4 & 4 & 2 \\
\hline Amapá & 16 & - & - & - & - & 1 & - & 1 & 4 & - \\
\hline Tocantins & 139 & 33 & 14 & 18 & 12 & 15 & 4 & 8 & 7 & 3 \\
\hline Nordeste & 1787 & 306 & 421 & 311 & 187 & 181 & 81 & 67 & 38 & 37 \\
\hline Maranhão & 217 & 99 & 35 & 12 & 8 & 13 & 3 & 4 & 2 & 2 \\
\hline Piauí & 221 & 29 & 59 & 53 & 28 & 9 & 6 & 4 & 1 & 2 \\
\hline Ceará & 184 & 16 & 49 & 48 & 25 & 23 & 6 & 3 & 2 & 2 \\
\hline Rio Grande do Norte & 166 & 49 & 49 & 21 & 14 & 9 & 3 & 3 & 3 & 2 \\
\hline Paraíba & 223 & 44 & 95 & 40 & 17 & 8 & 6 & 3 & 3 & 2 \\
\hline Pernambuco & 185 & 13 & 21 & 35 & 26 & 32 & 13 & 18 & 9 & 10 \\
\hline Alagoas & 101 & 13 & 19 & 9 & 5 & 4 & 6 & 3 & - & 2 \\
\hline Sergipe & 75 & 11 & 22 & 13 & 8 & 5 & 5 & 6 & 2 & 1 \\
\hline Bahia & 415 & 32 & 72 & 80 & 56 & 78 & 33 & 23 & 16 & 14 \\
\hline Sudeste & 1666 & 25 & 86 & 141 & 140 & 194 & 192 & 227 & 253 & 366 \\
\hline Minas Gerais & 853 & 23 & 68 & 95 & 90 & 112 & 104 & 135 & 116 & 103 \\
\hline Espírito Santo & 77 & - & - & 4 & 6 & 15 & 10 & 16 & 11 & 15 \\
\hline Rio de Janeiro & 91 & 1 & 5 & 2 & 9 & 5 & 8 & 8 & 17 & 36 \\
\hline São Paulo & 645 & 1 & 13 & 40 & 35 & 62 & 70 & 68 & 109 & 212 \\
\hline Sul & 1159 & 12 & 63 & 90 & 100 & 209 & 130 & 181 & 181 & 189 \\
\hline Paraná & 399 & 5 & 27 & 25 & 35 & 66 & 47 & 77 & 52 & 62 \\
\hline Santa Catarina & 293 & - & 16 & 21 & 23 & 48 & 31 & 43 & 44 & 66 \\
\hline Rio Grande do Sul & 467 & 7 & 20 & 44 & 42 & 95 & 52 & 61 & 85 & 61 \\
\hline Centro-Oeste & 446 & 21 & 27 & 45 & 42 & 68 & 48 & 81 & 74 & 36 \\
\hline Mato Grosso do Sul & 77 & 2 & 1 & 3 & 4 & 13 & 2 & 17 & 24 & 11 \\
\hline Mato Grosso & 126 & 3 & 8 & 16 & 9 & 17 & 15 & 24 & 22 & 9 \\
\hline Goiás & 242 & 16 & 18 & 26 & 29 & 38 & 31 & 40 & 28 & 15 \\
\hline Distrito Federal & 1 & - & - & - & - & - & - & - & - & 1 \\
\hline
\end{tabular}

Fonte: IBGE, Diretoria de Pesquisas, Coordenação de População e Indicadores Sociais, Pesquisa de Informações Básicas Municipais $1999 / 2001$.

(1) Inclusive os ignorados e os sem declaração de existência. 
